ANDREIA CRISTINA BAGATIN

\title{
O PROBLEMA DA CAPTURA DAS AGÊNCIAS REGULADORAS INDEPENDENTES
}

Dissertação apresentada como requisito parcial para a obtenção do grau de Mestre em Direito, perante o Programa de Pós-Graduação da Faculdade de Direito da Universidade de São Paulo, Departamento de Filosofia e Teoria Geral do Direito.

Professor Orientador: Doutor Celso Fernandes Campilongo

Faculdade de Direito da Universidade de São Paulo

SÃO PAULO 
ANDREIA CRISTINA BAGATIN

\section{O PROBLEMA DA CAPTURA DAS AGÊNCIAS REGULADORAS} INDEPENDENTES

Dissertação apresentada como requisito parcial para a obtenção do grau de Mestre em Direito, perante o Programa de Pós-Graduação da Faculdade de Direito da Universidade de São Paulo, Departamento de Filosofia e Teoria Geral do Direito.

Professor Orientador: Doutor Celso Fernandes Campilongo

Faculdade de Direito da Universidade de São Paulo

$$
\text { SÃO PAULO }
$$




\section{TERMO DE APROVAÇÃO}

\section{ANDREIA CRISTINA BAGATIN \\ O PROBLEMA DA CAPTURA DAS AGÊNCIAS REGULADORAS INDEPENDENTES}

Dissertação aprovada como requisito parcial para a obtenção do grau de Mestre em Direito, perante o Programa de Pós-Graduação da Faculdade de Direito da Universidade de São Paulo, Departamento de Filosofia e Teoria Geral do Direito.

Orientador:

Professor Doutor Celso Fernandes Campilongo

Departamento de Filosofia e Teoria Geral do Direito - USP

Membros

Professor Doutor

Professor Doutor 


\section{AGRADECIMENTOS}

O que somos é resultado das organizações de que participamos e da influência das pessoas que nos circundam. Tive a sorte de estar inserida em organizações da mais alta qualidade e cercada por pessoas que dão efetivo sentido à palavra generosidade.

Quanto às organizações, preciso agradecer especialmente a duas delas. Primeiro, meus agradecimentos se dirigem à Faculdade de Direito da Universidade Federal do Paraná. Devo à UFPR a minha formação jurídica e o despertar para a pesquisa. Mas não só. Lá, lugar em que seus egressos sempre se sentem em casa, tive oportunidade de participar de profícuas discussões no Núcleo de Estudos de Direito Econômico (NUPEDE), cujos frutos estão, de alguma forma, presentes neste trabalho. Agradeço também à Faculdade de Direito da Universidade de São Paulo. Tenho claro que cada uma das dificuldades enfrentadas para cursar o Mestrado fora de casa valeu a pena. Mais que isso: a pena transmudou-se no privilégio de conviver com a diversidade acadêmica que só se encontra nas Arcadas.

Quanto às pessoas, preciso agradecer a inúmeras (na acepção própria da palavra, já que incontáveis). Com a indicação de alguns nomes, tento homenagear a todos os que me auxiliaram durante esse período.

Inicialmente, agradeço ao professor Celso Fernandes Campilongo, orientador deste trabalho e exemplo de comprometimento acadêmico ímpar. Sou especialmente grata ao professor Celso pela sua pronta e incansável disponibilidade e por sua constante preocupação com o desenvolvimento deste trabalho. Foi, para mim, uma honra e um verdadeiro aprendizado ter com ele convivido ao longo dos últimos anos.

Agradeço, também, aos professores Jean Paul Cabral Veiga da Rocha e Ana Maria de Oliveira Nusdeo pela atenção que dispensaram a este trabalho quando do exame de qualificação. As sugestões formuladas em tal oportunidade foram de grande valia para o aprimoramento da dissertação.

Sou grata, ainda, ao professor e amigo Egon Bockmann Moreira. Devo ao professor Egon o meu desenvolvimento profissional e o fortalecimento da minha formação 
acadêmica. Como se não fosse o bastante, dele recebi constante incentivo para buscar a realização de objetivos que se afiguravam (em princípio) inalcançáveis. Também por isso, obrigada!

Agradeço também ao Duílio e à Inês, meus pais. Sou especialmente grata por me mostrarem que persistência e dedicação são excelentes instrumentos de trabalho. Agradeço, também, ao André e à Adriane, meus irmãos. O primeiro por haver se tornado ao longo do tempo um verdadeiro amigo de sangue. A segunda porque sua pura e simples existência lembra-me todos os dias o que efetivamente importa nessa vida. Por fim, agradeço ao querido Endrigo. Por tudo! Mas, em especial, porque sutilmente transforma os meus projetos em nossos, a ponto de eu não conseguir ir adiante sozinha. 


\section{RESUMO}

Este trabalho busca analisar o problema da captura das agências reguladoras. Em primeiro lugar, ele aponta as principais funções e a estrutura das agências reguladoras. O Capítulo 2 examina as teorias que se dedicam ao problema e que entendem ocorrer, efetivamente, a captura das agências reguladoras. Neste contexto, trata-se da "teoria do ciclo de vida das agências reguladoras" e da "teoria econômica da regulação". Essas teorias defendem que as agências reguladoras estão intimamente ligadas aos setores econômicos e, desse modo, podem gerar prejuízos ao interesse público. Todavia, nos dias atuais, é difícil definir "interesse público" e "interesse particular". Assim, esta monografia defende que a captura envolve, em verdade, o comprometimento da imparcialidade dos responsáveis pelo exercício da regulação. O Capítulo 3 é dedicado à realidade brasileira. Aqui, algumas formas de relação entre Estado e Sociedade - prevalência de relações informais e pessoais, soluções ad hoc etc. - parecem facilitar a ocorrência de captura. Nessa toada, é possível detectar uma forma particular de captura no Brasil: o uso indevido da regulação técnica levada a efeito pelo Poder Central. O Capítulo 4 demonstra as dificuldades de se regular o sistema econômico em uma sociedade complexa. Assim, entende-se que o problema da captura é um "risco", que pode (ou não) acontecer. Finalmente, este trabalho tenta expor algumas alternativas para minimizar o risco de captura. Depois de relatar algumas teorias jurídicas que lidam com situações de "legalidade fronteiriça" (abuso de direito, sham exception e desvio de poder), este trabalho conclui que, para minimizar o risco de captura, é mais adequado promover mudanças institucionais. 


\begin{abstract}
This work aims to analyze the capture of regulatory agencies. First of all, it presents the main functions and the structure of regulatory agencies. Chapter 2 examines theories that have recognized the occurrence of capture. In this context, it deals with "regulatory agencies life cycle theory" and "economic theory of regulation". These theories defend that the regulatory agencies are closely linked to industries and, in this way, they harm public interest. Nowadays, it is hard to define "public interest" and "private interest". Therefore, this research defends that regulatory agencies capturing involves, in fact, the impartiality compromising of those who have to exercise the regulation. Chapter 3 is dedicated to the Brazilian reality. Here, some forms of relationship between State and Society - informal and personal linkages, ad hoc solutions, etc. - seem to facilitate the capturing occurrence. In this manner, it is possible to detect a particular form of capturing in Brazil: undue use of technical regulation in favor of the central Government. Chapter 4 examines the difficulties of the economic system regulation in a complex society, showing capturing as a "risk" which may (or may not) happen. Finally, this work tries to expose some ways of minimizing this risk. After reporting some law theories which deal with "frontiers of legality" - abuse of rights, sham exception, and abuse of discretion - this work concludes that to minimize the risk of capture is more adequate to adopt some institutional changes.
\end{abstract}


Marco Polo descreve uma ponte pedra por pedra.

- Mas qual é a pedra que sustenta a ponte? - pergunta Kublai Jan.

- A ponte não é sustentada por esta ou por aquela pedra - responde Marco - , mas pelo arco que as pedras formam.

Kublai permanece silencioso, refletindo. Depois acrescenta:

- Por que me fala das pedras se o que importa é o arco?

Polo responde:

- Sem pedras não há arcos.

(Italo Calvino, Le città invisibili) 


\section{SUMÁRIO}

INTRODUÇÃO. 4

1. HiPÓTESE E PLANO DE TRABALHO .4

2. A METODOLOGIA EMPREGADA NO DESENVOLVIMENTO DO TRABALHO.. 6

CAPÍTULO 1: AGÊNCIAS REGULADORAS INDEPENDENTES. .8

1.1. O SUBSTRATO FÁTICO PARA A CRIAÇÃO DAS AGÊNCIAS REGULADORAS ... 8

1.2. A CRIAÇÃO DE UM TIPO IDEAL DE AGÊNCIAS REGULADORAS. 13

1.2.1. A justificativa para a construção de um tipo ideal..... 13

1.2.2. Um tipo ideal de agência reguladora independente ..... 15

a) A função ideal-típica das agências reguladoras 15

b) A estrutura ideal-típica das agências reguladoras 21

\section{CAPÍTULO 2: O PROBLEMA DA CAPTURA DAS AGÊNCIAS REGULADORAS}

2.1. AS TEORIAS QUE EXPÕEM O PROBLEMA DA CAPTURA. .25

2.1.1. A teoria do ciclo de vida das agências reguladoras...................................... 26

2.1.2. A teoria econômica da "captura" dos reguladores ....................................... 31

a) As críticas dirigidas à explicação econômica do problema da captura ................. 35

b) Os novos aportes para o exame da teoria da captura ......................................... 37

c) As críticas dirigidas aos pressupostos teóricos da explicação econômica do problema da captura

2.1.3. Conclusão parcial: exame das duas vertentes teóricas para a explicação da captura

2.2. A CARACTERÍSTICA CENTRAL DAS EXPLICAÇÕES PARA A OCORRÊNCIA DA CAPTURA: O COMPROMETIMENTO DO INTERESSE PÚBLICO EM BENEFÍCIO DO INTERESSE PRIVADO.........51

2.2.1. O espaço dado para a atuação do regulador ..................................................... 51

2.2.2. As dificuldades de eventual identificação do interesse público .......................... 52

a) A chancela legal do regulador e o método de validação da norma regulatória ..... 55

b) O necessário "desinteresse”" do responsável pela edição da regulação ..................57

2.3. A AUTONOMIA DO REGULADOR EM FACE DOS INTERESSES EM JOGO ..........................58

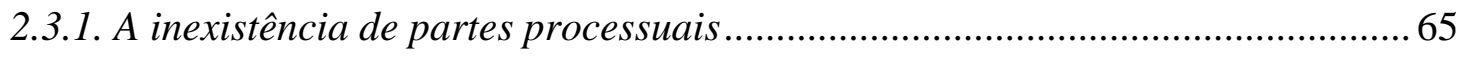

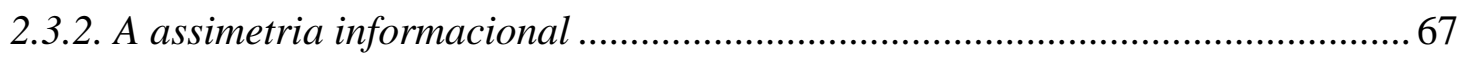


2.3.3. Os diferentes niveis de "poder" e "controle" exercido pelas (e sobre as) agências reguladoras independentes

\section{CAPÍTULO 3: O PROBLEMA DA CAPTURA E A REALIDADE BRASILEIRA .. 82}

3.1. OS MODOS DE INTERAÇÃO ESTADO-SOCIEDADE EXISTENTES NA REALIDADE BRASILEIRA

3.2. O MODUS OPERANDI DA CRIAÇÃO E DA APLICAÇÃO NORMATIVAS 88

3.3. O PROBLEMA DA CAPTURA NA REALIDADE BRASILEIRA: EXCESSO DE AUTONOMIA OU FALTA DELA?. 92

3.4. OS CANAIS INSTITUCIONAIS DE COMUNICAÇÃO CRIADOS PELAS AGÊNCIAS REGULADORAS INDEPENDENTES

3.5. UM COMPROMETIMENTO À BRASILEIRA DA IMPARCIALIDADE DAS AGÊNCIAS REGULADORAS INDEPENDENTES: O USO DA REGULAÇÃO TÉCNICO-ECONÔMICA PELO PODER CENTRAL . .95

\section{CAPÍTULO 4: A CARACTERIZAÇÃO DO PROBLEMA DA CAPTURA COMO RISCO DECORRENTE DA REGULAÇÃO................................................................... 108}

4.1. O EXERCÍCIO DE REGULAÇÃO NA SOCIEDADE COMPLEXA........................................ 108 4.1.1. O problema da captura como expressão do dilema "Quem guarda os guardiães?"

4.1.2. O problema da captura como sintoma das dificuldades do exercício da regulação em uma sociedade complexa

4.1.3. A criação de agências reguladoras como reação às dificuldades relacionadas ao exercício da regulação estatal.

4.2. PROBLEMA DA CAPTURA: CARACTERÍSTICA INERENTE À REGULAÇÃO? 122

4.3. A CARACTERIZAÇÃO DO PROBLEMA DA CAPTURA COMO UM RISCO. 128

4.3.1. Pressuposto teórico: teoria dos sistemas 128

4.3.2. O conceito de risco de LUHMANN.... 128

4.3.3. A associação do problema da captura à noção de risco. 130 4.4. A DIFERENCIAÇÃO FUNCIONAL DOS SISTEMAS JURÍDICO E POLÍTICO E O TRATAMENTO DOS RISCOS. 134

4.4.1. A diferenciação funcional dos sistemas jurídico e político 134

4.4.2. O tratamento do risco pelo sistema político e a repercussão para o sistema jurídico 
5.2. AS TEORIAS JURÍDICAS EXISTENTES PARA SITUAÇÕES DE FRONTEIRA DE LEGALIDADE

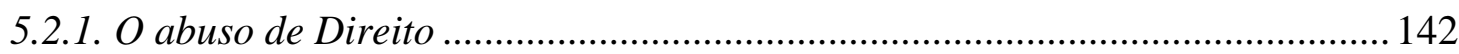

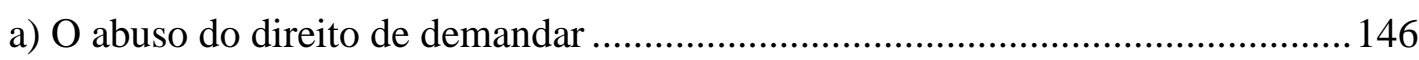

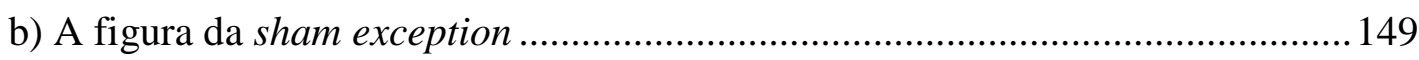

c) A liberdade de manifestação perante os órgãos públicos e o abuso de direito ... 158

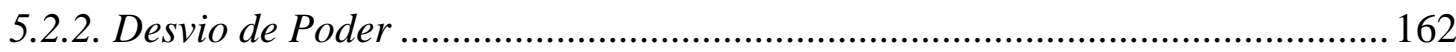

5.3. O AMBIENTE INSTITUCIONAL PROPÍCIO A MINIMIZAR O PROBLEMA DA CAPTURA......... 170

5.3.1. As situações propícias à ocorrência de captura ............................................. 172

5.3.2. As medidas sugeridas para o tratamento do risco de captura .......................... 173

a) A lei de fixação de competências regulatórias ................................................ 173

b) O procedimentalização da atividade regulatória .............................................. 175

b.1) Participação nos processos de atuação das agências reguladoras ........... 176

b.2) Fundamentação das decisø̃es ................................................................... 186

5.3.3. O controle das atividades regulatórias ......................................................... 188

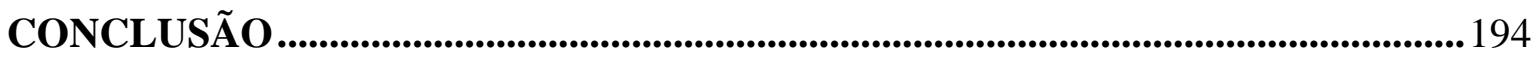

REFERÊNCIAS BIBLIOGRÁFICAS....................................................................2201 


\section{INTRODUÇÃO}

Desde a introdução das agências reguladoras no país, os estudos que sobre elas se dedicam mencionam o problema da captura. Nas obras recentes acerca da regulação estatal são várias as referências à captura e constantes as indicações de que se trata de uma distorção a ser corrigida. ${ }^{1}$ Embora tais alertas, ainda não houve oportunidade para que o problema fosse examinado de modo detido e exclusivo pela doutrina jurídica, com vistas ao exame teórico da questão. Em outras palavras: em âmbito nacional, os estudos jurídicos demonstram a preocupação de se alertar acerca dos riscos de captura, mas ainda não foi desenvolvido trabalho que se dedique exclusivamente ao tema. Assim, o objetivo do presente estudo é a análise particular do problema da captura das agências reguladoras independentes e, em especial, do tipo de comprometimento que tal problema gera sobre essas organizações.

\section{Hipótese e plano de trabalho}

A hipótese desenvolvida na presente pesquisa envolve investigar em que consiste a captura das agências reguladoras independentes e de que modo esse fato pode ser tomado como um problema para o sistema jurídico. Para tanto, está dividida em cinco capítulos, além desta introdução e da conclusão.

Inicialmente, com o fito de compreender as diferentes razões pelas quais as agências reguladoras independentes foram criadas, entende-se necessário examinar os diversos substratos fáticos que permearam a criação dessas organizações nos Estados Unidos, na Europa e no Brasil. Além disso, diante da disparidade de regimes jurídicos das

\footnotetext{
${ }^{1}$ Destaquem-se as menções ao problema da captura constantes nos textos de ALEXANDRE SANTOS DE ARAGÃo, Agências reguladoras e a evolução do Direito Administrativo Econômico. $2^{\mathrm{a}}$ ed. Rio de Janeiro: Forense, 2003, p. 365; ALKETA PECI e BIANOR SCELZA CAVALCANTI, “A outra face da regulação: o cidadãousuário de serviços públicos no novo modelo regulatório brasileiro". Revista de Direito Público da Economia. v. 3, Belo Horizonte, jul.-set. 2003, p. 13; CALIXTO SAlOMÃo FILHO, Regulação da atividade econômica (princípios e fundamentos jurídicos). São Paulo: Malheiros, 2001, p. 23; EROS ROBERTO GRAU, "Notas sobre o anteprojeto de lei atinente às agências". Revista de Direito Público da Economia. v. 4, Belo Horizonte, out./dez. 2003, p. 115; MARÇAL JUSTEN FILHO, O direito das agências reguladoras independentes. São Paulo: Dialética, 2002, p. 369; MÁRCiA MARGARETE FAGUNDES, "Teoria da captura do regulador de serviços públicos”. In: SOUTO, Marcos Juruena Villela; e MARSHALL, Carla C.. Direito empresarial Público. Rio de Janeiro: Lumen Juris, 2002, p. 251-284 e OdETE MedAuAR, O Direito Administrativo em evolução. $2^{a}$ ed. rev., ampl. e atual. São Paulo: RT, 2003, p. 262. De modo indireto, porque tratando de outro tema, o problema é considerado pelo professor FLORIANO PEIXOTO DE AZEVEDO MARQUeS NeTO, na obra Regulação Estatal e interesses públicos. São Paulo: Malheiros, 2002, p. 181-182. Em momento um pouco anterior a tais considerações, confiram-se as referências de FÁBIO NUSDEO, Fundamentos para uma codificação do direito econômico. São Paulo: RT, 1995; e, na década de 70, as de NELSON EIZIRIK, O papel do Estado na regulação do mercado de capitais. Rio de Janeiro: IBMEC, 1977.
} 
agências reguladoras brasileiras, parece oportuno construir um "tipo-ideal" de agência reguladora independente, a fim de que se possa identificar, com maior rigor e precisão, quais são as funções e qual é a estrutura que particulariza essas agências quando comparadas com outras formas de organização estatal. O primeiro capítulo deste trabalho dedica-se a essas duas tarefas iniciais.

A segunda parte do trabalho examina o problema da captura propriamente dito. Depois de expor as explicações econômica e de ciência política para o problema da captura e os desdobramentos que delas derivaram, a dissertação analisa a noção geralmente aceita de que a captura das agências reguladoras independentes envolve o comprometimento do interesse público em benefício do interesse privado. Diante da impossibilidade de se identificar, com precisão e aprioristicamente, a noção de interesse público, a dissertação investiga a possibilidade (e maior adequação) de se tratar o problema da captura como comprometimento da imparcialidade do responsável pela regulação. Uma vez realizada tal investigação, pretende verificar quais são as características peculiares ao exercício da regulação por meio de agências independentes que autorizariam a assertiva de que essas organizações estatais são mais sensíveis à ocorrência de captura. Nesse ponto, estuda-se, especialmente, a dependência informacional que se estabelece entre regulador e regulado.

No capítulo seguinte, a presente pesquisa dedica-se à análise da realidade brasileira, abordando o modo como se desenvolvem as relações Estado-sociedade em âmbito nacional. Na seqüência, pretende avaliar se essas características podem, de alguma forma, incentivar a ocorrência do problema da captura e quais são as nuances que o problema adquire na realidade nacional.

Ocorre que, embora seja possível identificar incentivos e situações propícias à ocorrência de captura (tal como a presença de espaço para a atuação do regulador não sujeito a controle e, mesmo, o contexto social em que as agências reguladoras estão inseridas), o problema da captura é contingente (pode - ou não - ocorrer). Assim, o quarto capítulo busca demonstrar que a captura da agência reguladora deve ser tomada como um risco que decorre da regulação exercida na sociedade complexa. Embora não seja característica inexorável da regulação, o problema da captura é um risco que a acompanha e que merece ser tomado em consideração (inclusive pelo sistema jurídico), a fim de que se cogitem de mecanismos que possam minimizá-lo. 
Assim, o último capítulo investiga os limites e algumas possibilidades de tratamento para o risco de captura pelo sistema jurídico. Depois de diferenciar captura e lobby e examinar teorias jurídicas que tratam de situações de "legalidade fronteiriça" (e que, por esse dado, podem contribuir com o tratamento do problema da captura), pretendese indicar as características de um ambiente institucional propício a reduzir os riscos de ocorrência de captura.

\section{A metodologia empregada no desenvolvimento do trabalho}

Para que se possa compreender o modo como se pretende desenvolver a dissertação, deve-se fazer um esclarecimento metodológico.

Conforme identificado por JoHn NEVILLE KEYNES (ainda no século XIX), é possível estabelecer distinção entre ciência positiva e ciência normativa. Segundo esse autor, "a positive science may be defined as a body of systematized knowledge concerning what is; a normative or regulative science as a body of systematized knowledge relating to criteria of what ought to be, and concerned therefore with the idea as distinguished from the actual (...)"2. Assim, o objeto de cada uma delas também é diferente. Ainda segundo J. NEVILLE KEYNES, "The object of a positive science is the establishment of uniformities, of a normative science the determination of ideals, of an art the formulations of precepts". 3

Essa distinção - ainda que cunhada por um economista e, portanto, tomando em conta as peculiaridades da ciência econômica - permite identificar dois métodos diferentes de desenvolvimento de pesquisa nas ciências sociais. Se tomados como "tiposideais", pode-se afirmar que o "sentido" da ação do pesquisador da ciência positiva é diverso do "sentido" da ação do pesquisador da ciência normativa. ${ }^{4}$ Na ciência econômica positiva, o propósito é explicar “aquilo que é”. Portanto, tem por objeto a realidade presente. Na ciência econômica normativa, o propósito é explicar aquilo que "deve ser". Aqui, as teorias e os resultados não pretendem explicar o presente, mas ditar considerações para o futuro.

\footnotetext{
${ }^{2}$ The Scope and Method of Political Economy. Kitchener: Batoche Books, 1999, p. 22.

${ }^{3}$ The Scope and Method of Political Economy. Ob. cit., p. 22. Essa diferença é adotada por MILTON FRIEDMAN, em artigo que se tornou célebre quanto à metodologia da ciência econômica contemporânea ("The Methodology of Positive Economics". Essays in positive economics. Chicago: University of Chicago Press, 1966, p. 3-16, 30-43).

4 Como o vocabulário utilizado denuncia, o referencial teórico para essa construção são categorias weberianas (Economia e Sociedade. vol. I, Trad. de Regis Barbosa e Karen Elsabe Barbosa, São Paulo: Editora UNB/Imprensa Oficial do Estado de São Paulo, 2004, p. 4-5). Parcela das vantagens de utilizá-las é tratada ao longo da parcela já escrita da dissertação (conforme Capítulo 1, item 1.2.1, infra).
} 
No desenvolvimento do presente trabalho, o método preponderante de abordagem é o analítico-positivo. Busca-se, portanto, construir uma explicação adequada para o problema da captura e a sua ocorrência. Para tanto, entendeu-se necessário utilizar referenciais teóricos de economia e sociologia, não só porque é nessas searas que se encontram as vertentes teóricas que se dedicaram a examinar especificamente o problema, mas também porque as duas disciplinas fornecem aportes significativos para explicar as relações que se estabelecem entre os agentes envolvidos na regulação. Somente ao final na parcela do trabalho em que se pretende identificar mecanismos jurídicos que podem contribuir para que a ocorrência do problema seja minimizada - é que se utilizou o método normativo de análise. 


\section{CAPÍTULO 1: AGÊNCIAS REGULADORAS INDEPENDENTES}

\subsection{O substrato fático para a criação das agências reguladoras}

Ao estudar empiricamente organizações empresariais privadas, ALFRED CHANDLER desenvolveu a tese de que "a estrutura acompanha a estratégia e que o tipo mais complexo de estrutura é resultado da articulação de várias estratégias básicas". 5 De acordo com CHANDLER, as diferentes organizações empresariais (estruturas empresariais) estão correlacionadas com as diferentes formas de expansão empresarial (estratégias empresariais). A estratégia é a definição de macro-objetivos das empresas. Uma vez definidos esses objetivos, tendem a surgir estruturas com vistas a atingir essas finalidades. ${ }^{6}$

A tese, que teve impacto no estudo do moderno empreendimento empresarial privado, não encontrou eco no estudo das organizações da Administração Pública. Porém, e de acordo com Giandomenico Majone, a tese é a elas aplicável. ${ }^{7}$ Segundo o autor italiano, é possível conectar o surgimento de determinadas estruturas administrativas (agências reguladoras, v.g.) com a definição de determinadas políticas públicas, isto é, com a adoção de determinadas estratégias pelo Estado (liberalização, privatização e desregulação, v.g.). O presente trabalho parte de tal tese para explicar a criação das agências reguladoras independentes. Isto é, tenta investigar a partir de qual estratégia (qual opção de política pública) criaram-se determinadas estruturas (as agências reguladoras independentes).

A criação das agências reguladoras independentes tem sua matriz na história da Administração Pública norte-americana. ${ }^{8}$ De acordo com STEPHEN BREYER e RICHARD STEWART, "The principle of free and equals markets unfettered by government restrictions and grants of monopolistic 'privileges' was a fundamental tenet in post-Revolutionary

\footnotetext{
5 AlFRED CHANDLER, "Introdução a Strategy and structure". In: McCRAW, Thomas K. (Org.). Alfred Chandler: ensaios para uma teoria histórica da grande empresa. Trad. de Luiz Alberto Monjardim. Rio de Janeiro: FGV, 1998, p. 137.

${ }^{6}$ ALFRED CHANDLER, "Introdução a Strategy and structure”. Ob.cit., p. 136.

7 "Do Estado Positivo ao Estado Regulador: causas e conseqüências da mudança no modo de governança". Trad. de: Paulo Todescan L. Mattos. In: MATTOS, Paulo Todescan L. (org.). Regulação Econômica e democracia: o debate europeu. São Paulo: Singular, 2006, p. 53-54

${ }^{8}$ Há notícias de que as primeiras agências especializadas surgiram na Grã-Bretanha (1846). Todavia, envolveram um movimento descontínuo (com a extinção prematura das comissões inicialmente criadas). Segundo ROBERT E. CUSHMAN, não há evidências empíricas que permitam afirmar que o movimento norteamericano foi influenciado pela experiência britânica (The independent regulatory commissions. New York: Octagon Books, 1972, p. 34 e ss, especialmente p. 36).
} 
America". 9 Diante disso, e embora possam ser denominados como um "temporário interlúdio", o final do século XVIII e o início do século XIX privilegiavam o mercado e o Judiciário como as instituições responsáveis pela alocação econômica e social de recursos. ${ }^{10}$ Logo, a estratégia era a não-intervenção na esfera econômica ${ }^{11}$ e as estruturas a ela vinculadas eram o mercado e, em casos limites, o Judiciário.

A estratégia passa a se alterar na segunda metade do século XIX, relativamente a importante setor econômico para a época: o setor ferroviário. ${ }^{12}$ Além da aprovação das Granger legislations em nível estadual e do reconhecimento da constitucionalidade de tais estatutos ${ }^{13}$, havia um movimento favorável à instituição de regulação. Entre 1868 e 1886, havia mais de 150 propostas legislativas para que se introduzisse controle federal sobre o setor ferroviário, por meio das mais diferentes formas de regulação. ${ }^{14}$ Ao final, as propostas prevalentes podiam ser classificadas em dois grandes grupos: o primeiro, embasado na proposta do Juiz Reagan, defendia a criação de uma regulação rígida por meio de legislação a ser aplicada diretamente pelo Departamento de Justiça e pelo Judiciário; o segundo, capitaneado pelo Senador Cullom, sustentava que a regulação das ferrovias deveria ser atribuída a uma comissão criada com este propósito específico. ${ }^{15}$ Prevaleceu o segundo entendimento que redundou na criação do ICC (Interstate Commerce Commission) em 1887 (primeira agência norte-americana independente de índole federal). Assim, a alteração da estratégia (a passagem do laissezfaire ao reconhecimento de necessidade de regulação, isto é, de intervenção estatal em setor econômico específico) foi acompanhada por uma alteração de estrutura (passa-se da

\footnotetext{
${ }^{9}$ Administrative Law and Regulatory Policy. Boston and Toronto: Little, Brown and Company, 1979, p. 22.

${ }^{10}$ StePhen BReYer e Richard Stewart, Administrative Law and Regulatory Policy. Ob. cit., p. 22.

${ }^{11}$ Em que pese se estar diante do "heyday do laissez-faire", não se pode deixar de considerar que o Estado tinha um papel de relevância na Economia. Exemplo disso era a competência estatal para definir impostos, conceder patentes, doar terras públicas para a construção de ferrovias, etc. (STEPHEN BREYER e RICHARD STEWART, Administrative Law and Regulatory Policy. Ob. cit., p. 22).

${ }^{12}$ A relevância do setor era de tal ordem que houve quem chegasse a afirmar que "Railroading influenced American society in the late nineteenth century as only television would in the late twentieth - or as the Roman Catholic had influenced the life of medieval Europe"(THOMAS K. MCCRAW, Prophets of regulation. Cambridge and London: Harvard University Press, 1984, p. 4-5).

${ }^{13}$ Trata-se de textos legais que permitiram a regulação das tarifas de transporte em âmbito estadual. A questão foi submetida à Suprema Corte norte-americana, que proferiu seis decisões no sentido de que o Governo detém o direito de regular as tarifas cobradas pelo transporte e pela armazenagem dos bens. Entendeu-se que as atividades em questão afetam o interesse público e, portanto, deviam ser submetidas à autoridade regulatória do Governo. Essas decisões são as denominadas Granger cases, dentre as quais a mais citada é a decisão Munn v. Illinois, 94, US.113 (1876)). Sobre a atribuição dessa nomenclatura ao conjunto de diplomas legais e aos casos judiciais que geraram (e, mesmo, sobre a correção de utilizá-la), confira-se o texto de JAMES K. EDSALL, "The Granger cases and the Police Power". Report of the Tenth Annual Meeting of the American Bar Association. vol. X, New York, 1887, p. 288-316.

${ }^{14}$ ROBERT E. CUSHMAN, The independent regulatory commissions. Ob. cit., p. 41.

${ }^{15}$ ROBERT E. CUSHMAN, The independent regulatory commissions. Ob. cit., p. 45.
} 
confiança no mercado à criação de agências reguladoras especializadas).

Na Europa do século XX, a estratégia de intervenção do Estado no domínio econômico foi diferente da adotada nos Estados Unidos, o que rendeu estruturas diversas das agências reguladoras. Em vez de se valer de uma comissão independente com atuação sobre a atividade econômica, os países europeus buscaram a intervenção direta na atividade econômica. ${ }^{16}$ Essa estratégia diferenciada resultou na constituição de estruturas administrativas igualmente diversas: a criação de empresas públicas e sociedades de economia mista, que viabilizassem essa atuação direta do Estado. As agências reguladoras independentes são estruturas que surgem na Europa no final do século XX (década de 1980), acompanhando as então novas estratégias de atuação em face de atividades econômicas: privatização, liberalização e desregulação. Quando se passa da estratégia de atuação no domínio econômico para a de atuação sobre o domínio econômico, cria-se uma nova estrutura administrativa para fazer frente a essa nova estratégia: as agências reguladoras independentes. Ainda que sem utilizar a nomenclatura aqui empregada, esse último fenômeno é passível de ser identificado nas lições de Vital MOREIRA e FERNANDA MAÇÃS:

A emergência de orientações privatizadoras e o generalizado movimento de liberalização da economia que, desde a década de oitenta do século passado, caracterizaram a Europa, desde logo no âmbito da Comunidade Económica Europeia - aliás num quadro de amplitude mundial com origem nos Estados Unidos da América -, tiveram como conseqüência uma substancial alteração do papel do Estado neste domínio. Uma das manifestações mais visíveis deste novo papel do Estado traduziu-se na criação de entidades de regulação, essencialmente independentes do Governo, com finalidades específicas de regulação para garantir a constituição e o funcionamento de um verdadeiro mercado concorrencial. ${ }^{17}$

Se nos Estados Unidos as agências reguladoras independentes surgem como a estrutura para viabilizar a estratégia de atuação do Estado na economia (rectius: atuação do Estado sobre a economia), elas surgem na Europa em outro contexto: isto é, como modo de viabilizar a estratégia de reduzir a atuação do Estado na economia, transformando-a em atuação sobre a atividade econômica. Conforme SABINO CASSESE, "negli Stati Uniti, lo sviluppo delle independent regulatory agencies fu il frutto

\footnotetext{
${ }^{16}$ A diferença entre atuação do Estado sobre a atividade econômica e atuação do Estado na atividade econômica vale-se da distinção cunhada por EROS ROBERTO GRAU. Segundo o autor, quando "o Estado intervém no domínio econômico", ele "[d]esenvolve ação, então, como agente (sujeito) econômico" (A ordem econômica na Constituição de 1988. $8^{\text {a }}$ ed. rev. e atual. São Paulo: Malheiros, 2003, p. p. 126). Quando o Estado atua sobre o domínio econômico, "[d]esenvolve ação, então, como regulador dessa atividade" (A ordem econômica na Constituição de 1988. $8^{\text {a }}$ ed. rev. e atual. São Paulo: Malheiros, 2003, p. 127).

${ }^{17}$ Autoridades reguladoras independentes: estudo e projeto de lei-quadro. Coimbra: Coimbra Editora, 2003, p. 9.
} 
dell'allargamento della government regulation e della produzione di diritto mediante leggi. In Italia, invece, l'instituzione di autorità indipendenti è stata accompagnata da un cambiamento di registro della disciplina pubblica delle attività private, dirette ora piuttosto alla liberalizzazione, alla deregulation, alla sostituzione di norme finalistiche con norme condizionale"18 Enquanto nos Estados Unidos as agências reguladoras surgem para propiciar o primeiro movimento em direção à intervenção do Estado sobre a atividade econômica, na Europa as agências surgem em um momento que conjuga retração da atuação estatal na economia e alteração qualitativa do modo como o Estado passa a atuar sobre o âmbito econômico.

No Brasil, a criação de agências reguladoras acompanha movimento similar ao assistido na Europa. Trata-se de estruturas administrativas que acompanharam a estratégia de alteração do modo de atuação do Estado sobre a economia, isto é, acompanharam os movimentos de privatização e liberalização de setores econômicos essenciais ocorridos em meados da década de 1990. À época, não havia normas legais e regulatórias claras para esses setores econômicos. Essas normas legais - usualmente denominadas marcos regulatórios ${ }^{19}$ - foram editadas concomitantemente aos processos de privatização e liberalização. E, nesse contexto, as agências reguladoras assumem a responsabilidade de regular os setores estratégicos a partir desses marcos.

Porém, na realidade brasileira, a criação das agências reguladoras como estruturas responsáveis pela regulação econômica assume especial relevância. O sucesso dos movimentos de privatização e de liberalização dependia da atração de investidores privados. Ocorre que a avaliação dos investidores privados para aportar valores em um determinado projeto tenta mensurar os custos a que esse projeto está sujeito. Isso envolve uma avaliação não só dos valores que precisam ser empregados diretamente no empreendimento, mas também dos denominados "custos de transação" a ele vinculados. A expressão econômica "custos de transação" refere-se aos custos atrelados à celebração de um negócio (custos relativos à obtenção de informações, à negociação do contrato, à elaboração do contrato e à eventual imposição das regras nele previstas). Tal como afirma

\footnotetext{
18 "Le autorità indipendenti: origini storiche e problemi odierni". In: CASSESE, Sabino e FRANCHINI, Claudio. I garanti delle regole. Bologna: Il Mulino, 1996, p. 219.

${ }^{19}$ Não se desconhece a crítica do STF à expressão "marco regulatório" (BRASIL, STF, Tribunal Pleno, Ação Direta de Inconstitucionalidade 3.521-6, Rel. Min. EROS GRAU, j. 28.09.2006. DJU 16.03.2007). De toda a forma, entende-se que a expressão é útil, especialmente para aludir ao texto legislativo fundamental de determinado setor econômico, no qual se encontra a fixação dos standards mínimos da atividade e dos objetivos que devem ser atingidos pelo regulador.
} 
RONALD COASE - a quem se atribui a teoria dos custos de transação -

In order to carry out a market transaction it is necessary to discover who it is that one wishes to deal with, to inform people that one wishes to deal and on what terms, to conduct negotiations leading up to a bargain, to draw up the contract, to undertake the inspection needed to make sure that the terms of the contract are being observed, and so on. These operations are often extremely costly, sufficiently costly at any rate to prevent many transactions that would be carried out in a world in which the pricing system worked without cost. ${ }^{20}$

Portanto, na decisão do investimento também se levam em conta os custos de negociação de um eventual contrato, a possibilidade de que a avença venha a ser alterada ou descumprida ao longo de sua execução e os custos para vê-la cumprida. Para levar a efeito a avaliação desses custos, é relevante o arcabouço institucional a que o projeto está vinculado. Na síntese de Douglass C. NORTH, "when it is costly to transact, institutions matter". ${ }^{21}$ Aliás, de acordo com esse autor, as instituições são, elas mesmas, determinantes para a apuração dos custos de transação e para a decisão de se ingressar (ou não) em determinada atividade econômica, pois "Institutions provide the basic structure by which human beings throughout history have created order and attempted to reduce uncertainty in exchange. Together with the technology employed, they determine transaction and transformation costs and hence the profitability and feasibility of engaging in economic activity". ${ }^{22}$

Ocorre que, em meados da década de 1990, o Brasil havia recém-saído de uma fase de significativa instabilidade institucional (tentativa de tratamento da hiperinflação por meio de sucessivos planos econômicos e alterações legislativas cotidianas). Naquele momento,

A partir da complexidade dos inúmeros problemas que precisam ser equacionados de modo congruente por esses políticos, os códigos, as leis e até mesmo a própria ordem constitucional parecem ser vistos não propriamente como um 'frame' institucional, que fornece as 'regras do jogo' ao estabelecer tanto os direitos e os deveres dos cidadãos quanto as competências e os limites de ação dos governantes, mas sim como um mero recurso de poder à disposição destes últimos, por meio do qual implementam e executam decisões sempre justificadas em nome de um equilíbrio apresentado como sendo de 'interesse público'. ${ }^{23}$

A descrição de JOSÉ EDUARDO FARIA torna clara não só a inexistência de um arcabouço institucional que garantisse as regras do jogo, como a utilização ad hoc

\footnotetext{
20 "The problem of social cost". In: The firm, the market and the law. Chicago and London: The University of Chicago Press, 1990, p. 114.

${ }^{21}$ Institutions, institutional change and economic performance. Cambridge: Cambridge University Press, $\mathrm{p}$. 12.

${ }^{22}$ Institutions, institutional change and economic performance. Ob. cit., p. 118.

${ }^{23}$ José EdUARDo FARIA, Direito e economia na democratização brasileira. São Paulo: Malheiros Editores, 1993, p. 11.
} 
dessas regras. As agências regulatórias independentes surgem, assim, como uma nova estrutura de organização da atuação estatal não só porque seriam mais aptas a implementar a regulação econômica em setores estratégicos, mas também porque eram organizações que concediam maior estabilidade institucional (e, consequentemente, forneciam a credibilidade de que o país precisava para atrair investimentos privados). ${ }^{24}$

\subsection{A criação de um tipo ideal de agências reguladoras}

\subsubsection{A justificativa para a construção de um tipo ideal}

Os tipos ideais configuram um recurso metodológico que facilita a investigação e a exposição de fenômenos reais. De acordo com MAX WEBER, “Obtém-se um tipo ideal mediante a acentuação unilateral de um ou vários pontos de vista, e mediante o encadeamento de grande quantidade de fenômenos isoladamente dados, difusos e discretos, que se podem dar em maior ou menor número ou mesmo faltar por completo, e que se ordenam segundo os pontos de vista unilateralmente acentuados, a fim de se formar um quadro homogêneo de pensamento". ${ }^{25}$ Trata-se de uma construção teórica, em que se acentuam particulares elementos da realidade, facilitando a exposição e a compreensão de determinado fenômeno da realidade. ${ }^{26}$ As justificativas para se ter optado por esse recurso metodológico são de duas ordens.

As primeiras envolvem as facilidades que a utilização desse recurso

\footnotetext{
${ }^{24}$ Estudo do Banco Mundial acerca dos investimentos privados nos setores de infraestrutura dos países emergentes indica que "The general lesson from analitycal and empirical literature is that, by affecting investor confidence, the stability and predictability of the incentive framework may be even more important than the level of investment incentives in determining the volume of private investment" (SHEOLI PARGAL, "Regulation and private sector investment in infrastructure: evidence from Latin America". Policy Research Working Paper $\mathrm{n}^{\mathrm{o}}$ 3037. The World Bank, abr. 2003, p. 7-8, disponível em: http://papers.ssrn.com /sol3/papers.cfm?abstract_id=636399. Último acesso em: 01.07.2008). Essas lições são confirmadas nas conclusões dessa pesquisa ao se afirmar que "A particularly intuitive result is that private investment is positively associated with the independence and credibility of regulator, particularly its ability to commit" (SHEOLI PARGAL, "Regulation and private sector investment in infrastructure: evidence from Latin America". Ob. Cit., p. 23).

25 "A "objetividade" do conhecimento nas ciências sociais. Trad. de Gabriel Cohn. In: COHN, Gabriel (org.) e FERNANDES, Florestan (coord.). Max Weber. $7^{\mathrm{a}}$ ed., São Paulo: Ática, 2006, p. 106.

${ }^{26}$ Relativamente ao recurso a "tipos-ideais", duas advertências merecem ser feitas. Por um lado, e embora a construção do tipo-ideal tenha como ponto de partida elementos encontrados na realidade, o tipo com ela não se confunde. O tipo-ideal implica a acentuação de determinados elementos do fenômeno real, mas os dados reais não coincidem exatamente com essa acentuação. Por outro, o tipo ideal não tem a pretensão de ser uma construção teórica exemplar, no sentido de expressar um "dever-ser". Tal como afirma o próprio Weber, "Trata-se [o tipo ideal] de um quadro de pensamento, e não da realidade histórica, e muito menos da realidade 'autêntica', e não serve de esquema no qual se pudesse incluir a realidade à maneira de exemplar. Tem antes o significado de um conceito limite puramente ideal, em relação ao qual se mede a realidade a fim de esclarecer o conteúdo empírico de alguns dos seus elementos importantes, e com o qual esta é comparada". (“A “objetividade” do conhecimento nas ciências sociais". Ob. cit., p. 109).
} 
proporciona. Em que pesem as críticas que a ele podem ser dirigidas ${ }^{27}$, o tipo-ideal permite a clarificação de classes de fenômenos. Por meio dele, constrói-se, em abstrato e de modo estritamente lógico, um tipo racional de ação. Esse tipo - que não se encontra na realidade, mas que é uma espécie de caricatura do que na realidade se encontra ${ }^{28}$ - permite compreender melhor os fenômenos reais. Ao comparar o tipo e a realidade, podem-se identificar eventuais "desvios" desta em relação àquele, trazendo a lume aspectos da ação humana que não são pautados por critérios estritamente racionais. ${ }^{29}$

A segunda ordem de motivos que levaram à opção pelo uso do tipo-ideal envolve as características das agências reguladoras brasileiras.

Por um lado, no Brasil, não se tem uma lei-quadro que estabeleça o regime geral das agências reguladoras, que permita a generalização das características dessa forma de organização administrativa. ${ }^{30}$ Cada uma das agências é constituída por legislação específica, que apresenta diferenças quanto à estruturação e às competências a elas atribuídas. O recurso ao tipo-ideal permite que se acentuem as características mais específicas e essenciais das agências reguladoras (em que pesem as diferenças das leis de criação e dos regimes jurídicos a que estão submetidas), facilitando a compreensão do fenômeno.

Por outro, as agências reguladoras independentes brasileiras não deixam de ser influenciadas pela realidade em que estão inseridas. O recurso ao tipo-ideal permite que se identifiquem, de modo mais claro, as diferenças existentes nessa nova estrutura organizacional ("agências reguladoras independentes"), a despeito da influência da realidade em que vêm a se inserir e da eventual dificuldade para produzir os efeitos que delas se esperam. ${ }^{31}$ Enfim: entende-se que as agências reguladoras envolvem modificações

\footnotetext{
${ }^{27}$ Quanto às críticas a esse recurso metodológico, podem ser conferidas as remissões feitas por FRITZ RINGER aos trabalho de DIETER HENRICH e W. G. RUNCIMAN (A metodologia de Max Weber: unificação das ciências culturais e sociais. Trad. de Gislon César Cardoso de Sousa. São Paulo: Edusp, 2004, p. 119-120).

${ }^{28}$ Ou para usar as palavras de WEBER, "essa construção reveste-se do caráter de uma utopia, obtida mediante a acentuação mental de determinados elementos da realidade" ("A "objetividade" do conhecimento nas ciências sociais". Ob. cit., p. 105).

${ }^{29}$ Quando se fala em "desvio", não se está a fazer remissão a qualquer visão pejorativa ou crítica a ações pautadas em critérios não-racionais. Tal como destaca o próprio WEBER, utilizar o tipo-ideal significa, tãosomente, um recurso metodológico. A partir dele, "Não se pode, portanto, imputar-lhe a crença em uma predominância efetiva do racional sobre a vida" (Max Weber. Economia e Sociedade. Trad. de Regis Barbosa e Karen Elsabe Barbosa. São Paulo: Editora UNB/Imprensa Oficial do Estado de São Paulo, 2004, p. 5.), assim como não se está a criticar essa ausência de proeminência.

${ }^{30}$ Por ora, existe um projeto de lei (PL 3337/2004) que pretende estabelecer regime jurídico uniforme para as agências reguladoras.

${ }^{31}$ Sobre essa questão, ver o Capítulo 3, infra.
} 
estruturais na forma de organização do Estado. E tais modificações podem ser mais bem apreendidas por meio de instrumentos de Sociologia. Assim, e aproveitando a tradição weberiana na Sociologia do Direito, o presente trabalho vale-se dos "tipos-ideais", com fins exclusivamente explicativos.

\subsubsection{Um tipo ideal de agência reguladora independente}

A construção do tipo-ideal ainda seguirá a tese de AlFRED CHENDLER, de modo que serão expostas, primeiramente, as características essenciais relativas às funções desempenhadas pelas agências reguladoras (a estratégia de atuação do Poder Público no âmbito econômico) e, na sequência, serão indicadas as características atinentes à estrutura das agências cunhadas com vistas ao cumprimento daquelas funções. Essa separação facilita a exposição, mas também busca estabelecer a comunicação entre a função (estratégia) e a estrutura, levando em consideração a lição de NORBERTo BOBBIO, segundo a qual:

Enfim, se quisermos deduzir uma consideração final, tal seria que a análise estrutural, atenta às modificações da estrutura, e a análise funcional, atenta às modificações da função, devem estar continuamente alimentadas e avançar lado a lado, sem que a primeira, como ocorreu no passado, eclipse a segunda, e sem que a segunda eclipse a primeira como poderia ocorrer em uma inversão de perspectivas a que os hábitos, as modas, o prazer do novo pelo novo, são particularmente favoráveis. $^{32}$

\section{a) A função ideal-típica das agências reguladoras}

A tentativa de identificar a função (ou as funções) desempenhada pelas agências reguladoras depende, inicialmente, de se verificar a finalidade a que essas agências se prestam. Como se exerce a função com vistas a um determinado fim, a identificação das funções exercidas pelas agências reguladoras e da pertinência de que essas tarefas sejam a elas outorgadas depende, antes, de se verificar a finalidade buscada por essas agências. Porém, identificar o fim das agências reguladoras é tarefa complexa, especialmente quando se consideram os diferentes setores a que se destinam regular e os motivos que deram origem à criação de cada uma das agências. Partir-se-á do exame dos

\footnotetext{
32 "A análise funcional do direito: tendências e problemas". Da estrutura à função: novos estudos de teoria do direito. Trad. de Daniela Beccaccia Versiani, Barueri: Manole, 2007, p. 113. A remissão à lição de BoBBIO no mesmo locus a que se faz referência à teoria empresarial de ALFRED CHANDLER deve ser acompanhada da advertência de que o objeto de pesquisa de cada um deles é distinto. Enquanto CHANDLER estuda a estrutura empresarial - e daí GIANDOMENICO MAJONE identificar a possibilidade de que sua teoria fosse utilizada para explicar organizações administrativas -, a teoria de BOBBIO tem em vista explicar o Direito (seja sob o ângulo estrutural, seja sob o ângulo funcional) como um todo. De toda a forma, e para o fim que se pretende nessa parcela do trabalho, a citação das lições de BoBBIO revela-se útil: coloca foco na relação de complementaridade entre estrutura e função.
} 
diferentes motivos que justificam a existência de regulação por meio de agências reguladoras independentes, a fim de tentar identificar a finalidade a que se prestam.

Tal como já indicado, nos Estados Unidos, as agências reguladoras surgem como estrutura que substitui as regras do livre mercado. Ou, em outras palavras, aparecem como modo de suprir as falhas que paulatinamente são identificadas no funcionamento livre dos mercados. STEPHEN G. BREYer e Richard B. Stewart, ao mesmo tempo em que alertam que uma mesma regulação pode ter diferentes justificativas, tentam arrolar os motivos que explicam que ela exista. Segundo os autores, a existência de regulação pode ser justificada pelas seguintes razões: $(i)$ a necessidade de controlar o poder de monopólio: quando uma empresa atua em monopólio em determinado mercado, tende a ampliar seus lucros mediante a redução da quantidade de produtos que coloca à disposição dos consumidores, bem como pela fixação de preços em patamar mais alto que o dos preços competitivos; (ii) a necessidade de controlar lucros sem lastro de justificação (windfall profits): trata-se de controlar a renda que pode resultar, por exemplo, do repentino aumento no preço das commodities. Esse "lucro" pode ser realizado por aqueles que eventualmente têm a commodity em estoque ou que controlem uma fonte não-duplicável dessa commodity; (iii) a necessidade de corrigir os custos derivados de externalidades ("spillover costs"): isto é, trata-se de controlar as situações em que a produção de determinado bem impõe custos para toda a sociedade; (iv) a necessidade de compensar a assimetria de informações: a informação pode ser encarada como uma "mercadoria", isto é, um "produto" para o qual há oferta e demanda. Porém, o mercado desse "bem" é imperfeito. Os consumidores, embora tenham interesse na informação, não têm como partilhar os custos para a sua obtenção. A regulação prestar-se-ia a compensar a informação inadequada ou a reduzir os custos de sua obtenção; (v) a necessidade de eliminar competição excessiva: em mercados que têm custos fixos altos e demandas cíclicas ou em situações de preços predatórios, poder-se-ia cogitar de regulação que vise a essa finalidade ${ }^{33}$; (vi) a necessidade de aliviar a escassez, seja em situações de crise (boicote no fornecimento de determinado bem), seja em virtude da deliberada decisão de retirar certa atividade do mercado. ${ }^{34}$

Em termos mais sucintos, os cinco primeiros motivos aventados pelos

${ }^{33}$ Os autores reconhecem que essa justificativa para a regulação tem intensas raízes históricas (Administrative Law and Regulatory Policy. Ob. cit., p. 15).

${ }^{34}$ Administrative Law and Regulatory Policy. Ob. cit., p. 12-18. 
autores citados envolvem a utilização de regulação para solucionar falhas de mercado. O último dos motivos envolve, em parte, a tentativa de afastar determinada falha de mercado (situações de crise), mas se relaciona especialmente com as situações em que se pretende, de modo deliberado, retirar a atividade do mercado. A regulação é justificada por motivos diversos dos econômicos, sendo possível vinculá-la à noção de regulação social (isto é, a promoção de valores diferentes do bom funcionamento do mercado). ${ }^{35}$

$\mathrm{Na}$ Europa, o surgimento das agências reguladoras acompanha, em grande medida, os movimentos de desestatização, privatização e liberalização. Daí se compreender que a função da regulação é a de promover o livre mercado e a concorrência em atividades que anteriormente não estavam a eles submetidos. Tal como afirmam FABIO MERUSi e Michele PASSARO, as agências reguladoras que se voltam à regulação econômica "sono autorità di tutela della liberta economica, di salvaguardia della libertà economica nei confronti dell'indirizzo político economico governativo". ${ }^{36}$ Esse dever de tutela da liberdade econômica (que surge como espécie de imposição da Comunidade Européia) destina-se, por um lado, a proteger a liberdade econômica fundada na livre competição; por outro, nos setores em que a concorrência ainda não existe, tem a função de criar as condições para que se instale, ou mesmo, a de criá-la artificialmente. Sob certo ângulo, essa tendência aproxima-se da idéia de correção de falhas de mercado: onde o mercado não funciona adequadamente em termos concorrenciais, a regulação é exercida para suprir as "falhas" e dotar o mercado de condições para que ela passe a funcionar. Porém, pode haver setores em que "a concorrência penetra, mas que ela não governa

\footnotetext{
${ }^{35}$ Quanto à possibilidade (ou não) de dissociação entre regulação econômica e regulação social, ver o texto de Diogo Rosenthal CoutinHo, "Entre eficiência e eqüidade: a universalização das telecomunicações em países em desenvolvimento". Revista Direito GV, v. 1., n. 2., jun-dez 2005, p. 137-160.

${ }^{36}$ Le autorità indipendenti: um potere senza partito. Bologna: il Mulino, 2003, p. 102. Ao lado das agências reguladoras que têm por objeto os setores econômicos, os autores também destacam a existência de autoridades reguladoras independentes que visam à tutela da liberdade individual, isto é, protegem atividades que, por serem invasivas, poderiam ser manipuladas caso submetidas ao âmbito político. O exemplo mais corrente é a regulação de mídia. Diante dos limites do presente trabalho, esse tipo de regulação não será aqui tratado. O exame do tema pode ser ampliado em MARÇAL JUSTEN FILHO ( $O$ direito das agências reguladoras independentes. São Paulo: Dialética, 2002, p. 178 e ss). Além disso, deve-se destacar que o entendimento de que a regulação europeia do final do século XX presta-se a tutelar a liberdade econômica não é opinião isolada dos autores citados e nem mesmo da doutrina italiana. Trata-se de ideia que encontra expressão no direito francês (MARIE-ANNE FRISON ROCHE. "Definição do direito da regulação econômica". Revista de Direito Público da Economia - RDPE. n. 9, Belo Horizonte, jan-mar 2005, p. 207-217), no direito espanhol (GASPAR ARIÑO ORTIZ, La regulación econômica: teoría y práctica de la regulación para la competência. Buenos Aires: Editorial Ábaco de Rodolfo Depalma, s/d, p. 85-88) e no direito português (VITAL MOREIRA E FERNANDA MAÇÃs, Autoridades Reguladoras Independentes: estudo e projecto de lei-quadro. Ob. cit., p. 2324).
} 
sozinha". ${ }^{37}$ Dessa forma, "o sistema de regulação cria e mantém um equilíbrio entre a concorrência e outro princípio além da concorrência dentro dos setores econômicos que não os podem criar ou manter por si próprios ou apoiando-se somente sobre o quadro geral do direito da concorrência". 38

No Brasil, a regulação também acompanha os movimentos de desestatização, privatização e liberalização. Porém, ao lado de se buscar a redução da participação direta do Estado, a criação e a tutela do mercado, havia a preocupação com a criação de um arcabouço institucional consistente, que viabilizasse a realização de investimentos necessários nas atividades que viessem a ser privatizadas ou liberalizadas.

Ao examinar a plêiade de fins anteriormente enunciados, a questão que se põe é a de saber se há um traço comum que os conecte. Seria possível sintetizar, em um só dado, a finalidade última da regulação? Nessa tentativa, entende-se possível identificar como fim da regulação a tutela da existência, higidez e disponibilidade da atividade regulada à generalidade dos indivíduos (aqui compreendidos os usuários atuais e as gerações futuras). Com essa definição, quer-se dizer que a regulação não tem por finalidade prestigiar uma ou algumas das partes submetidas à regulação (sejam os usuários, os regulados ou o poder político). Ainda que aparentemente possa se constatar eventual benefício a determinados indivíduos, entende-se que a regulação tem por fim a tutela da atividade ela mesma, de molde a garantir que permaneça existindo e seja ofertada à generalidade dos indivíduos (tanto no presente quanto no futuro).

Quando se examinam as diversas justificativas para o exercício da regulação, é possível identificar, como fim último, a busca dessa tutela.

Tomem-se detidamente as diferentes justificativas para a existência de regulação elencadas por BREYER e STEWART anteriormente referidas. Se se tenta identificar o que se pretende tutelar quando se entende justificável a regulação em casos de poder de monopólio, lucros despidos de justificação, externalidades, assimetria de informações e competição excessiva, a resposta mais imediata é a tutela do mercado livre. Entende-se que a supressão das falhas de mercado permite funcionamento próximo ao mercado livre e competitivo. Isso significaria a disponibilização dos bens e serviços em questão mediante o

\footnotetext{
${ }^{37}$ Embora em outro contexto, a síntese aqui mencionada é de MARIE-ANNE FRISON Roche. "Definição do direito da regulação econômica". Ob. cit., p. 217.

${ }^{38}$ MARIE-ANNE FrISON ROCHE. "Definição do direito da regulação econômica". Ob. cit., p. 214.
} 
menor preço possível (preço equivalente ao competitivo ou ao menor preço possível para a situação). ${ }^{39}$ Por sua vez, a regulação também pode ter por fundamento o "interesse público", o que justificaria a exclusão da regulação das regras do mercado.

O que parece haver em comum nas duas justificativas é que ambas visam à tutela da atividade regulada. A razão para se tutelar as regras de mercado ou se criar as condições para que as regras do mercado funcionem tem por fundamento o fato de que o mercado concorrencial (ou a sua mimetização) permite a disponibilização dos bens ou serviços (da atividade regulada) a partir dos melhores preços possíveis. O mesmo vale para a justificativa de interesse público. Se se entende que a atividade deve ser retirada do mercado é porque se imagina que a atividade poderá existir e ser mais bem disponibilizada ao público em geral a partir de referenciais diferentes daqueles presentes no livre mercado.

O mesmo parece se aplicar às justificativas utilizadas na Europa para a instituição de regulação por meio de agências reguladoras. Na Europa, entende-se que a atividade deve ser submetida ao livre mercado, mas que tal medida deve ser precedida de uma "preparação" feita por meio da regulação e, eventualmente, pode haver situação em que não haverá aplicação exclusiva do princípio da livre concorrência. O que, enfim, justificaria essa percepção final? Ao que parece, a necessidade de não se colocar em risco a atividade em si. Quer-se tutelar as regras do livre mercado, mas, antes, visa-se tutelar a atividade regulada. Isso se torna ainda mais claro quando se cogitam de novos campos para a regulação, nos quais “A concorrência que era o termo principal da equação, em relação ao qual os outros princípios se organizavam, poderia passar ao status de uma das considerações que podem existir em equilíbrio com o essencial da regulação, que seria então a prevenção dos riscos". ${ }^{40}$ Considerando-se a tese de MARIE-ANNE FRISON-RochE, a regulação deixa de privilegiar a concorrência e passa a visar, primordialmente, a prevenção de riscos (ou seja, passa a buscar a manutenção da higidez da atividade regulada).

\footnotetext{
${ }^{39}$ Em termos econômicos, os preços competitivos seriam aqueles que coincidiriam com o custo marginal (isto é, com o custo necessário para a produção de mais uma unidade do bem ou serviço). Porém, há alguns bens e serviços que exigem investimentos iniciais extremamente altos e, posteriormente, o custo marginal é baixo ou nulo. Cogite-se, por exemplo, acerca da construção de uma hidrelétrica para a geração de energia. Nessa situação, o custo de geração da primeira unidade de energia elétrica corresponde ao custo de todo o investimento na hidrelétrica. Porém, o custo marginal (o custo para gerar a segunda unidade de energia) é zero, eis que a hidrelétrica que gera uma unidade de energia tem condições de gerar a segunda sem nenhum custo adicional. (Cf. TRAIN, Kenneth E. Optimal Regulation: the economic theory of natural monopoly, Cambridge and London: MIT Press, 1991, p. 1-17).

${ }^{40}$ MARIE-ANEe FrISON-Roche. Os novos campos da regulação. Revista de Direito Pública da Economia RDPE. n. 10, Belo Horizonte, abr-jun 2005, p. 194.
} 
As justificativas da regulação no Brasil também permitem reconduzir à noção de tutela da atividade. Por um lado, a idéia de introdução da concorrência segue modelagem similar à europeia, isto é, introduz-se concorrência desde que ela se revele viável para manter a atividade. Caso contrário, a regulação pode servir para mimetizar o funcionamento concorrencial ou mesmo para afastá-lo. Além do regime jurídico específico brasileiro $^{41}$, o que parece justificar se se terá concorrência ou regulação (que mimetiza a competição ou a substitui) é a necessidade de manutenção da atividade. Por outro, se a criação do arcabouço institucional tinha em mira a obtenção dos investimentos, não se pode deixar de levar em conta que os investimentos buscados eram os necessários para a manutenção e o desenvolvimento das atividades reguladas. Em outras palavras: o objetivo final é, mesmo, a tutela da atividade submetida à regulação.

Assim, a macrofinalidade da regulação (independente dos motivos imediatos e enunciados) é a existência e a manutenção da atividade regulada hígida e disponível à generalidade dos usuários. Como consequência, são outorgadas às agências reguladoras as funções que permitam a busca daquela finalidade. Tal como afirma VITAL MoreIRA, "O essencial do conceito de regulação é o de alterar o comportamento dos agentes económicos (produtores, distribuidores, consumidores), em relação ao que eles teriam se não houvesse a regulação, isto é, se houvesse apenas as regras do mercado." Para levar a efeito essa medida, normalmente há edição de uma lei-quadro (loi cadre), que se resume a uma "autorização para agir" para a agência reguladora. ${ }^{43}$ Para que tutele a atividade regulada, essa autorização normalmente envolve a outorga de competências para (i) formular as normas de orientação do setor; (ii) viabilizar a implementação das regras, praticando os atos administrativos pertinentes; (iii) levar a efeito a fiscalização e a

\footnotetext{
${ }^{41}$ No Brasil, as atividades econômicas qualificadas como serviços públicos estão submetidas a regime jurídico específico (CF, art. 175), ao qual é intrínseca a titularidade do Poder Público e a necessidade de regulação. Porém, nada obsta que essa regulação vise à criação e ao incentivo da concorrência entre os agentes prestadores do serviço.

${ }_{42}$ Auto-regulação profissional e Administração Pública. Coimbra: Almedina, 1997, p. 36. No mesmo sentido, JULIA BLACK, "Constructing and Contesting Legitimacy and Accountability in Polycentric Regulatory Regimes". LSE - Law, Society and Economy Working Papers. vol. 2/2008, p. 8. Disponível em: <http://eprints.lse.ac.uk/23040 /1/WPS2008-02_Black.pdf>. Último acesso em: 15.10.2009.

${ }^{43}$ Mesmo antes da criação das agências reguladoras no Brasil, a necessidade desse nível de abstração legal já era sentida. Nas palavras de FÁBIO NUSDEO, "O legislativo faz-se presente no campo econômico por meio de leis bastante amplas concernentes à criação dos órgãos e entidades encarregadas da execução da política econômica, fixando-lhes as atribuições, as competências e a composição. Por outro lado, podem traçar limites, em geral extremamente imprecisos, para a atuação das mesmas, bem como consignar objetivos gerais a serem atingidos e eventuais restrições quanto a objetivos concorrentes. É a denominada loi cadre pelos franceses ou legge cornice pelos italianos. No fundo, ela contém uma autorização para agir conferida a órgãos ou agências do Executivo." ("O direito econômico e os grupos de pressão". In: GRINOVER, Ada Pellegrini (Coord.). A tutela dos interesses difusos. São Paulo: Max Limonad, 1984, p. 131)
} 
aplicação de sanções nas hipóteses de descumprimento das regras. ${ }^{44}$ Assim, às agências são outorgadas funções de três ordens (normativas, executivas e parajudiciais), a fim de que possa tutelar, por completo, a atividade sob regulação.

\section{b) A estrutura ideal-típica das agências reguladoras}

Para que se possa levar a efeito a finalidade da regulação (em linhas gerais, a tutela da atividade regulada) e viabilizar o exercício das funções necessárias à busca daquela finalidade (funções normativa, executiva e parajudicial), é necessário que a organização responsável pelo exercício da regulação seja dotada de estrutura específica, compatível com o exercício dessas funções. Assim, a estrutura da agência reguladora dotase de características específicas, com vistas a poder bem exercer as funções que lhe são outorgadas.

Para o exercício de tais funções, entende-se que a agência reguladora deve ser independente (ou, como prefere AlEXANDrE SANTOS DE ARAGÃo ${ }^{45}$, dotada de autonomia reforçada), de molde que não esteja comprometida com nenhum dos grupos sujeitos à regulação e nem com o poder político. Como afirmam VITAL MoREIRA E FERNANDA MAÇÃS, "A independência é a característica essencial, o traço que permite distinguir estas entidades em relação às outras estruturas administrativas (...)". 46 A estrutura típico-ideal das agências reguladoras busca, então, dotar a agência dessa independência ou autonomia reforçada.

Em termos típicos-ideais, as agências reguladoras são órgãos colegiados, cujos dirigentes são recrutados externamente à Administração, a partir de critérios meritórios (isto é, em virtude da competência técnico-profissional dos sujeitos). A esses dirigentes são outorgados mandatos fixos e irrevogáveis, que não coincidem com o prazo da legislatura e do próprio período de mandato do Executivo, a fim de evitar que um só Governo e uma só legislatura possam modificar, por completo, a composição da agência. ${ }^{47}$

\footnotetext{
${ }^{44}$ Auto-regulação profissional e Administração Pública. Ob. cit., p. 36-37.

45 AleXANDRE SANTOS DE ARAGÃO, Agências Reguladoras e a evolução do direito administrativo econômico. $2^{\mathrm{a}}$ ed., Rio de Janeiro: Forense, 2003, p. 331 e ss.

${ }^{46}$ Autoridades Reguladoras Independentes: estudo e projeto de Lei-Quadro. Ob. cit., p. 25.

${ }^{47}$ Quanto à estabilidade dos mandatos, é paridmático o caso Humphrey's Executor vs. United States (1935), em que se rechaçou a possibilidade de o Chefe do Executivo afastar o dirigente de agência reguladora independente por motivos exclusivamente políticos. No caso concreto, Humphrey era um dos dirigentes da Federal Trade Comission (FTC), nomeado pelo Presidente Hoove e aprovado pelo Senado para exercer mandato entre 1931 e 1938. Em 1933, o Presidente Roosevelt remeteu-lhe correspondência pedindo para que renunciasse ao mandato, pois preferia contar com dirigentes por ele próprio selecionados. Como Humphrey
} 
Em virtude desse último objetivo, os mandatos dos dirigentes das agências envolvem lapso de tempo considerável, a fim de evitar que o objetivo visado pela ausência de coincidência dos mandatos dos dirigentes das agências com os mandatos políticos seja comprometido pela exigüidade do prazo. Normalmente, também se estabelece uma série de proibições para que os dirigentes exerçam atividades diversas das diretamente vinculadas à agência reguladora, em um sistema de incompatibilidades.

Fixadas as garantias de manutenção dos dirigentes nos cargo e a impossibilidade de que sejam de lá removidos imotivadamente, estabelecem-se as condições de independência no exercício das funções e competências que lhe são outorgadas. De nada adiantaria garantir a estabilidade no cargo, mas permitir que as ordens e diretivas editadas pela agência reguladora fossem revisadas por outro órgão ou entidade da Administração Pública. Daí que às garantias relacionadas à estabilidade no cargo unemse outras, tendentes a permitir que o exercício da regulação seja, de fato, independente (ou autônomo). Para isso, e também em termos típicos-ideais, os atos das agências reguladoras não são submetidos a ordens ou instruções baixadas pela Administração Pública, assim como não estão elas sujeitas ao controle hierárquico-administrativo. ${ }^{48}$

negou-se a renunciar, Roosvelt removeu-o do cargo, sob o argumento de que era melhor para a nação que o cargo fosse ocupado por pessoa de sua integral confiança. As questões enfrentadas no julgamento eram duas: a primeira era a de saber se havia limitação para que o Presidente removesse o dirigente da FTC; a segunda era a de saber se essa limitação era compatível com a Constituição Norte-Americana. Às duas perguntas, a resposta dada pela Suprema Corte foi positiva (Supreme Court of United States. 295 US 602, Humphrey's Executor vs. United States (1935). Disponível em: http://www.law.cornell.edu/supct/html/historics/USSC_ CR_0295_0602_ZO.html. Último acesso em: 1.10.2009). No Brasil, o entendimento prevalente era diametralmente oposto. A despeito do posicionamento contrário do Ministro VITOR NUNES LEAL, para quem "Visa a investidura de prazo certo a garantir a continuidade de orientação e a independência de ação de tais entidades autônomas, de modo que os titulares, assim protegidos contra as injunções do momento, possam dar plena execução à política adotada pelo Poder Legislativo, ao instituir o órgão autônomo, e definir-lhe as atribuições." (Supremo Tribunal Federal Pleno, Mandado de Segurança n ${ }^{\circ}$ 8.693, Relator MINISTRO RIBEIRO DA COSTA, DJ 20.08.1962), foi editado o verbete $\mathrm{n}^{\circ} 25$ de súmula do Supremo Tribunal Federal, segundo o qual "A nomeação a termo não impede a livre demissão, pelo Presidente da República, de ocupante de cargo de dirigente de autarquia". O posicionamento foi amenizado em relação ao cargo de reitor universitário mediante a edição do verbete $n^{\circ} 47$ de Súmula do Supremo Tribunal Federal, segundo o qual "Reitor de universidade não é livremente demissível pelo Presidente da República durante o prazo de sua investidura". Em relação às agências reguladoras independentes criadas na década de 1990, o tema foi discutido no julgamento da ADI-MC 1949. Nesse feito, o Supremo Tribunal Federal examinou a constititucionalidade da lei de criação da Agência Estadual de Regulação dos Serviços Públicos Delegados do Rio Grande do Sul e entendeu não haver incompatibilidade entre a criação de restrições para a exoneração de dirigentes de agências reguladoras independentes e a Constituição da República (Supremo Tribunal Federal, Pleno, Medida Cautelar em Ação Direta de Inconstitucionalidade $\mathrm{n}^{\circ}$ 1949, Relator Ministro Sepúlveda Pertence, DJ 25.11.2005).

${ }^{48}$ Vital MoReIRA e FERnANDA MAÇÃs, Autoridades Reguladoras independentes: estudo e lei quadro. Ob. cit., p. 22 e ss. Isso significa que a decisão das agências reguladoras não está submetida nem a recurso administrativo hierárquico e nem a sua atuação pode ser controlada por meio de "tutela administrativa". MARIA SYLVIA ZANELla DI PIETRO diferencia as duas realidades ao consignar que a admissão de recurso 
Ainda com vistas a garantir a autonomia no exercício das funções regulatórias, outro dado pode ser agregado: a exclusividade de atuação em relação à matéria regulada. Nas palavras de MARÇAL JUSTEN FILHO, "Serão muito mais autônomas as agências quando forem titulares privativas de certas competências". ${ }^{49} \mathrm{O}$ argumento é de ordem lógica e complementa os objetivos visados com as características anteriormente relatadas, pois a dificuldade em eventual partilha de competências pode fazer as vezes do controle hierárquico pela Administração. Se há um exercício compartilhado de competências, há a possibilidade de que a Administração Central valha-se dessa característica para ter a "palavra final" nos setores econômicos submetidos à regulação. ${ }^{50}$

Ao lado da independência da agência reguladora, a estrutura tem em mira garantir a neutralidade e a imparcialidade dessas agências. Pretende-se que as agências reguladoras sejam autônomas em relação à política e ao setor regulado, procedendo a um exame técnico (que, em virtude das características do setor submetido à regulação, revelase o modo mais adequado para manter a atividade e respectivas higidez e disponibilização à generalidade dos indivíduos) e atuando de modo a ponderar todos os interesses em jogo, sem discriminar nenhum deles. As características que pretendem viabilizar a neutralidade e a imparcialidade das agências são, por um lado, a procedimentalização da atividade das agências reguladoras, garantindo, por meio de canais institucionais, ampla participação no exercício da regulação (seja no exercício das funções normativas, isto é, na edição das regras regulatórias; seja nas atividades executivas e parajudiciais, isto é, na prática de atos

hierárquico impróprio significa conceder a outro órgão (normalmente, à Administração Direta) a possibilidade de revisar a decisão proferida pela Administração Pública Indireta (Direito Administrativo, 20 ed., São Paulo: Atlas, 2007, p. 680). Por sua vez, a tutela é “a fiscalização que os órgãos centrais das pessoas públicas políticas (União, Estados e Municípios) exercem sobre as pessoas administrativas descentralizadas, nos limites definidos em lei, para garantir a observância da legalidade e o cumprimento de suas finalidades institucionais" (Direito Administrativo, Ob. cit., p. 452)

${ }^{49} \mathrm{O}$ direito das agências reguladoras independentes. Ob. cit., p. 398.

${ }^{50}$ Não se olvide que o tema está aqui tratado em termos típicos-ideais. Em termos concretos, a questão é mais complexa. Se, por um lado, o argumento parece provado a partir dos dados que se verificam nos momentos de crise (a propósito, confira-se o texto de LEILA CuÉllar e EGON BOCKMANN MOREIRA ("As agências reguladoras brasileiras e a crise energética". Estudos de direito econômico, Belo Horizonte: Fórum, 2004, p. 207 e ss), no qual se relata que, na crise de energia de 2001, a solução do problema prescindiu da agência reguladora, instalando-se uma "Câmara de Gestão da Crise de Energia Elétrica - CGE", cuja presidência foi outorgada ao Chefe da Casa Civil, de forma que a ausência de exclusividade de atuação da agência acabou por reduzir o seu papel no momento em que o setor mais requereu atuação regulatória); por outro, a ausência de competência exclusiva pode ser encarada sob viés positivo, pois, ao mesmo tempo em que reduz a independência da agência, permite que ela fique sujeita a maior controle, ampliando o seu accountability (confira-se, a respeito, a intervenção de RONALDO PORTO MACEDO JÚNIOR no debate "Há um Déficit Democrático nas Agências Reguladoras?” (MARQUES NETO, Floriano de Azevedo (Coord.). Revista de Direito Público da Economia, vol. 5, jan-mar 2004, p. 181-182)). Assim, a outorga (ou não) de competências exclusivas parece envolver um trade-off entre a ampliação do nível de independência da agência reguladora versus ampliação do controle que sobre ela se exerce. 
administrativos concretos e na solução de conflitos); por outro, a outorga de poderes de investigação às agências reguladoras (por meio desses poderes, a agência pode buscar as informações de que necessita para melhor conhecer e controlar a atividade dos regulados).

Fixado o tipo-ideal de agências reguladoras - a partir das funções por ela exercidas e da estrutura de que são dotadas -, reputa-se delineado o objeto sobre o qual recaem as preocupações deste trabalho. Sendo assim, é possível tratar da captura das agências reguladoras independentes, tema central desta monografia, ao qual se dedicam os capítulos subsequentes. 


\section{CAPítulo 2: O PROBlema da CAPTURA dAS AGÊNCIAS REGULADORAS}

\subsection{As teorias que expõem o problema da captura}

A Economia reconhece que o pleno funcionamento dos mercados depende da supressão de falhas de mercado. O mercado, por si, não consegue limitar o poder econômico, eliminar as externalidades e a assimetria de informações ou distribuir de forma adequada os bens coletivos. ${ }^{51}$ Para que essas falhas sejam supridas (old style regulation) ou, mesmo, para que finalidades sociais sejam atingidas por meio do sistema econômico (modern style regulation), decisões políticas submetem alguns setores econômicos à regulação. Por meio delas, pretende-se que o comportamento dos agentes econômicos esteja alinhado com objetivos gerais. ${ }^{52}$ Considerando-se o entendimento defendido no capítulo anterior - no sentido de que a regulação tem por finalidade a manutenção da atividade regulada, de molde a que possa se desenvolver de modo hígido e que esteja à disposição da generalidade dos indivíduos -, também se tem que o objetivo da regulação é geral. Em suma: tem por objetivo alterar a conduta dos agentes econômicos a fim de obter a realização dessa finalidade geral.

Porém, a busca de objetivos gerais é colocada em xeque por aqueles que compreendem que a regulação, em verdade, pretende beneficiar interesses privados (sejam os interesses egoísticos do responsável pelo exercício da regulação, sejam os identificados com determinados grupos de interesse). Essa outra explicação para a existência de regulação tem amparo em duas vertentes teóricas diferentes. Por um lado, há a teoria do "ciclo de vida das agências reguladoras", segundo a qual o desempenho das atividades regulatórias acaba por criar um vínculo de dependência entre reguladores e regulados, ao ponto de o regulador passar a ser voz dos regulados. Por outro, há a teoria econômica da regulação, que identifica a existência de uma espécie de "captura” dos legisladores e reguladores pelos interesses que eles deveriam regular. Ambas as vertentes teóricas são

\footnotetext{
${ }^{51}$ Os termos em destaque são emprestados da ciência econômica e explicitados ao longo do presente trabalho quando utilizados pontualmente. De todo o modo, sobre essas noções, consulte-se a obra de ELIZABETH Maria Mercier Querido Farina, Paulo Furquim de Azevedo e Maria Sylvia Macchione Saes. Competitividade: mercado, Estado e organizações. São Paulo: Editora Singular, 1997.

52 O adjetivo "geral" foi aqui escolhido para corresponder aos efeitos que se espera da adoção das decisões coletivas sob responsabilidade do Estado. Os percalços para seleção do termo ficará evidente quando se expuser, em seguida, as dificuldades da expressão "interesse público" (vide item 2.2.2., infra).
} 
suscetíveis de críticas, que se procurará expor a seguir. Relativamente à teoria econômica da regulação, pode-se afirmar que ela foi "revisada" a partir de novos aportes teóricos, fornecendo explicações não só mais sofisticadas, mas também mais satisfatórias para a questão.

\subsubsection{A teoria do ciclo de vida das agências reguladoras}

Na década de 1950, dois teóricos estudaram o comportamento das agências reguladoras, observando que, com o passar do tempo, elas desenvolviam uma ligação mais estreita com os setores regulados a ponto de tutelarem os interesses desses setores.

Em primeiro lugar, destaca-se o trabalho de S. P. Huntington, que estudou o comportamento do ICC (agência reguladora responsável pela regulação do setor de transportes). ${ }^{53}$ Segundo o AUTOR, quando do surgimento da agência, ela atuava de modo independente em relação aos interesses que regulava. Nesse primeiro momento, contava com o apoio político de transportadores e agricultores, que defendiam a regulação com vistas à redução das tarifas praticadas pelo setor ferroviário. Ocorre que, paulatinamente, o ICC perde o apoio político daqueles dois grupos. Com isso, aproximou-se do setor ferroviário, criando um "escambo" entre os agentes econômicos e a agência. Por um lado, o setor ferroviário passou a defender a outorga de competência para o ICC e a manutenção de sua independência; por outro, a regulação passa a ser intensamente favorável ao setor ferroviário, a ponto de haver quem afirmasse a "tendency upon the part of the ICC to treat 'public interest' and 'railroad interest' as synonomous terms". 54

A analogia entre a evolução do comportamento da agência reguladora e o ciclo de vida humano é desenvolvida por MARVER H. BERNSTEIN. Esse autor participou de projeto de estudo acerca do funcionamento das agências reguladoras norte-americanas. Os resultados da pesquisa foram publicados na obra Regulating business by independent comission, cuja idéia central é a de que há espécie de "ciclo de vida das agências reguladoras independentes".

Embora admita as especificidades da experiência de cada agência, o autor entende possível detectar, por meio do exame de dados históricos, traços comuns na

\footnotetext{
53 "The marasmus of the ICC: The Commission, the Railroads by independent commission". Yale Law Journal, vol. 61, apr. 1962, p. 467-509.

54 The marasmus of the ICC: The Commission, the Railroads by independent commission”. Ob. cit., p. 498.
} 
evolução das agências. Em regra, essas entidades teriam experimentado fases equivalentes de crescimento, maturidade e declínio. Esses traços comuns e a repetição dos fenômenos sugerem a existência de um "ciclo natural" de vida das agências reguladoras. Equiparando a evolução das comissões independentes à vida humana, indica que o ciclo seria composto por quatro fases: gestação, juventude, maturidade e velhice.

A fase gestacional envolveria as discussões acerca do estatuto legal que cria a agência reguladora. Segundo BERNSTEIN, essa fase envolve tempo considerável (até que se tome consciência da necessidade de regular determinado setor) ou decorre de fatores supervenientes (crises econômicas, escândalos públicos etc.). Haveria sempre um embate entre grupos favoráveis à instituição da regulação versus grupos favoráveis à manutenção do status quo (ausência de regulação). O estatuto seria aprovado quando prevalecesse a idéia pró-regulação.

$\mathrm{Na}$ segunda fase, a agência deteria características similares àquelas da juventude: energia, ambição e imaginação. ${ }^{55}$ Haveria a tendência de que viesse a agir com firmeza em busca do interesse público, inclusive em oposição aos interesses dos grupos regulados. Segundo BERnSTEIN, esse modo de atuação é possível enquanto a comissão pode contar com a aceitação pública e a simpatia dos líderes políticos (tanto da Presidência, quanto de membros do Congresso). Porém, haveria uma evidente desproporção entre a coesão dos grupos regulados e o interesse público a ser tutelado pelas agências (incipiente e ainda não-organizado). De acordo com o AUTOR,

\begin{abstract}
When a regulatory commission is established, its real and potential capacities contrast sharply with those of the regulated groups. It lacks administrative experience, its policy and objectives are vague or unformed, its legal powers are unclear and untested, and its relations with Congress are uncertain. On the other hand, the regulated groups are well organized, with vital interests to protect against the onslaught of the regulators. The regulatory agency usually begins to formulate its program and to block out its major policies at a time when the regulated enterprises are highly developed and their technologies far advanced. ${ }^{56}$
\end{abstract}

A consequência disso é o declínio do apoio político e a tendência de isolamento das agências.

Assim, as agências chegariam à terceira fase (fase da "maturidade") sem qualquer apoio político. O Congresso relutaria em ampliar a autoridade das comissões e a regulação já não contaria com suporte popular.

\footnotetext{
55 MARVER B. BernSteIn, Regulating business by independent commission. Princeton: Princeton University Press, 1955, p. 77.

${ }^{56}$ Regulating business by independent commission. Ob. cit., p. 79.
} 
Nesse contexto, a comissão perde "vitalidade", ampliando a passividade tanto no que diz respeito a seus métodos quanto no que concerne às suas políticas. Em vez de uma ação prospectiva, são os precedentes que guiam o modo de agir da comissão nessa fase. A atuação é mais gerencial, afastando-se das atribuições de controle e fiscalização. As controvérsias desaparecem gradualmente e a comissão torna-se parte do sistema econômico de um determinado setor. A luta pelo controle da formulação das políticas regulatórias e para influenciar o processo regulatório passa a ser cuidadosamente calculada pelos regulados. A comissão torna-se mais preocupada com a manutenção do setor econômico e tenta prevenir mudanças que o contrariem.

Há, enfim, uma tendência à manutenção do status quo regulatório e de que as idéias favoráveis aos grupos regulados prevaleçam.

Na síntese de BERNSTEIN, "The close of the period of maturity is marked by the commission's surrender to the regulated. Politically isolated, lacking a firm basis of public support, lethargic in attitude and approach, bowed down by precedent and backlogs, unsupported in its demands for more staff and money, the commission finally becomes a captive of the regulated groups."

$\mathrm{Na}$ última fase, as agências tendem a adotar decisões de "segurança", compatibilizando seus objetivos com as demandas dos setores privados. Nesse momento, a relação entre a comissão e as partes privadas se torna tão fixa que as agências não conseguem se mobilizar contra os grupos regulados. A missão primária da agência passa a ser manutenção do setor regulado. Há uma "institucionalização do favoritismo", que seria incentivada pelo fato de a atuação das comissões estar restrita a um setor específico. ${ }^{58-59}$

O alerta feito pela teoria do "ciclo de vida das agências reguladoras",60,

\footnotetext{
${ }^{57}$ Regulating business by independent commission. Ob. cit., p. 90.

${ }^{58}$ Regulating business by independent commission. Ob. cit., 1955, p. 92.

${ }^{59} \mathrm{O}$ ciclo de vida das agências descrito por BERNSTEIN é marcado pela redução paulatina de apoio político. Porém, embora de forma não explícita, perpassa o texto a idéia de que a submissão da agência também é facilitada pela existência de agências reguladoras para setores específicos. Essa última idéia é sustentada por outros autores de modo explícito. A respeito, confiram os textos referidos na nota 366, infra.

${ }^{60}$ A teoria do ciclo de vida das agências reguladoras é criticada por LOUIS L. JAFFE. O autor concorda que as agências reguladoras não podem permanecer alheias ao controle político. Porém, afirma que os problemas invocados por BERNSTEIN seriam mais amplos, de molde que os invocar para criticar somente as agências reguladoras seria elegê-las como "bode expiatório" (scapegoat). Nesse sentido, destaca três pontos: $(i)$ a representação feita por grupos de interesses não é verificada exclusivamente na atuação das agências reguladoras; (ii) as críticas de BERNSTEIN desconsideram a complexidade inerente ao exercício da regulação. Como exemplo, utiliza as críticas dirigidas ao ICC. O motivo de se considerar a agência vinculada ao setor ferroviário é a ausência de competição na indústria, bem como o nível das tarifas fixadas pelo regulador.
} 
unido a outras análises sociológicas, torna a busca por segurança levada a efeito pelas agências reguladoras um fenômeno plausível. Nesse sentido, faz-se referência ao trabalho de PHILIP SELZNICK acerca da Tennessee Valley Authority (TVA), publicado em $1963 .{ }^{61}$

A TVA é uma agência criada no bojo do New Deal, com vistas a ampliar a utilização do rio Tennessee e incentivar o desenvolvimento agrícola e industrial da região (portanto, uma agência mais voltada ao fomento que à regulação setorial). ${ }^{62}$ Ao examinar um programa específico levado a efeito pela agência (distribuição de fertilizantes), SELZNICK identifica que o incentivo para a participação dos interessados (população e instituições locais) na estrutura da agência resultou que "poderosos centros de influência no Vale foram absorvidos, dissimuladamente, na estrutura de determinação política do TVA". ${ }^{63}$ Essa circunstância permitiu que se estabelecesse uma relação especial entre a agência e a American Farm Bureau Federation. Essa relação tornou-se tão estreita que, quando essa Federação se contrapôs à atuação das demais agências responsáveis pela política agrícola (Farm Security Administration e Social Conservation Service), a TVA não "conseguiu" apoiar suas "co-irmãs". De toda a forma, a possibilidade de participação das associações no âmbito da TVA fez com que houvesse uma formal distribuição de responsabilidades acerca das atribuições da agência (o que deu maior suporte a ela).

Para explicar esses fatos, SELZNICK vale-se de conceito por si denominado como “cooptação". Segundo o autor, cooptação envolve "o processo de absorção de novos elementos na liderança ou na estrutura de decisões políticas de uma organização, como

Porém, a teoria da regulação da época sustentava preferir uma "coordenação construtiva" (por meio de regulação) à "concorrência destrutiva". Na ocasião em que as tarifas do setor foram contrastadas com a legislação antitruste e levadas ao Poder Judiciário, o Congresso imediatamente as imunizou, evitando tal controle. Em suma: em vez de "industry-oriented", a atuação do ICC também pode ser interpretada como alinhada a ideias prevalentes na doutrina especializada e no próprio Congresso; (iii) os estatutos que outorgam competências para as agências reguladoras são genéricos na fixação das finalidades da regulação. O principal motivo de aproximação entre indústria e regulados seria a ausência de um guia seguro outorgado pelo Congresso. Segundo JAFFE, (...) "in the absence of clear mandate, it is not only inevitable, but appropriate that regulation take the form of an accommodation in which industry is the senior partner. This is the essence of "industry-orientation"”. ("The independent agency - a new scapegoat" (Review of Regulating Business by Independent Comission. By Marver H. Bernstein). The Yale Law Journal. vol. 65, 1955-1956, p. 1074). Assim, menos que na atuação da agência ela mesma, a aproximação entre regulador e regulado seria explicada pela falta de apoio do Congresso. Entende-se que a crítica de JAFFE, ao identificar a origem do problema da captura na falta de apoio claro do Congresso, corrobora a idéia de que a aproximação entre agências e grupos regulados é explicada pela busca de segurança por parte dos reguladores (explicada com maiores detalhes ao longo desta parcela do trabalho).

61 “Cooptação: um mecanismo para a estabilidade organizacional”. In: CAMPOS, Edmundo. Sociologia da burocracia. Trad. de Edmundo Campos, 4ª ed., Rio de Janeiro: Zahar Editores, 1978, p. 93-100.

${ }^{62}$ A propósito, confira-se o ato de constituição da TVA (disponível em http://www.tva.com/abouttva /pdf/TVA_Act.pdf, acessado em 27.10.2008).

63 "Cooptação: um mecanismo para a estabilidade organizacional”. Ob. cit., p. 98. 
meio de evitar ameaças à sua estabilidade ou existência.". ${ }^{64}$ Esse mecanismo envolve situações de cooptação formal, que se dá na necessidade de se estabelecer a legitimidade da agência ou de tornar a administração acessível ao público; e de cooptação informal, que ocorre em face da necessidade de a agência se ajustar às pressões de centros específicos de poder na sociedade. ${ }^{65}$ Nesse segundo aspecto,

(...) quando a cooptação se destina à realização de um ajustamento aos centros organizados de poder institucional, pode ser necessário manter relações que, embora sejam consequiências, são informais e encobertas. Se se tornam públicos os ajustamentos aos núcleos específicos de poder, a legitimidade da autoridade formal, como representativa de uma comunidade teoricamente indiferenciada (o povo como um todo), pode ser minada. ${ }^{66}$

E qual seria a razão pela qual a agência permitiria essa cooptação? Segundo SELZNICK, uma explicação possível é a necessidade de "segurança da organização como um todo frente às forças sociais de seu meio". ${ }^{67}$ Em outras palavras, a segurança é um objetivo visado pelas agências. E, para obtê-la, a agência pode se aproximar de grupos de interesse (em especial, daqueles que serão submetidos à regulação), com vistas a afastar as críticas que podem lhe ser dirigidas.

Em suma: a agência precisa de apoio e segurança para agir. Quando surge, conta com tais elementos derivados do suporte político que se lhe atribui. Com o passar do tempo, o apoio político diminui, mas a necessidade de segurança permanece, o que incentiva o estabelecimento de uma relação mais estreita entre regulador e regulado, nos termos antes expostos. ${ }^{68-69}$

\footnotetext{
64 “Cooptação: um mecanismo para a estabilidade organizacional”. Ob. cit., p. 93.

65 “Cooptação: um mecanismo para a estabilidade organizacional”. Ob. cit., p. 93.

66 “Cooptação: um mecanismo para a estabilidade organizacional”. Ob. cit., p. 95.

67 "Cooptação: um mecanismo para a estabilidade organizacional”. Ob. cit., p. 93.

${ }^{68}$ Embora sem usar a denominação "ciclo de vida das agências reguladoras", FÁBIO NuSDEO noticia esse movimento no curso da existência dos órgãos responsáveis pela edição de regras de direito econômico. Segundo o AUTOR, "Em órgãos, onde tantos e tão mal limitados poderes se reúnem, o critério do interesse público, na sua correta visão, tenderá sempre a prevalecer? Em determinados casos, poderá haver um período criador inicial, quando pessoas habilitadas e dedicadas darão o melhor de si para a criação de uma agência que reputem necessária ao aperfeiçoamento do sistema. Porém elas passam e o élan inicial eventualmente fenece. Uma vez consolidada, a agência passa a ser alvo de interesses, tanto da burocracia, como do setor privado e a marca originalmente imprimida possivelmente venha a ser alterada. Daí, adverte ainda Clark, resulta um duplo perigo: por um lado poderá decair o sentido marcante de função pública e, com o tempo, vir o órgão a se preocupar mais com a sua sobrevivência burocrática, o seu posicionamento e a sua influência no conjunto da administração; por outro lado, a atenção da opinião pública, sobre os vários temas de interesse da nação, sói ser intermitente e, nos intervalos cada vez mais amplos em que passa despercebida, a agência pode ser empalmada por interesses totalmente alheios aos seus fins. Nessas condições, o caráter democrático e representativo do governo passa a correr perigo. Conciliá-lo com sua indispensável função econômica, exercida através das agência, eis o grande desafio apresentado pelo novo sistema". ("O Direito Econômico e os grupos de pressão". In: GRINOVER, Ada Pellegrini (Coord.). A tutela dos interesses difusos. São Paulo: Max Limonad, 1984, p. 137).
} 


\subsubsection{A teoria econômica da "captura" dos reguladores}

Na década de 1960, ao realizar pesquisas empíricas relativas ao setor elétrico $^{70}$, GeOrge J. Stigler e Claire FrIEDland identificaram que os benefícios públicos "prometidos" pela regulação não eram faticamente verificáveis. Comparando os valores das tarifas de energia elétrica cobradas por empresas submetidas à regulação e aqueles praticados por empresas que não estavam a ela submetidas, não foram identificadas diferenças substanciais entre os preços praticados.

O que explicaria esse resultado?

Para HAROLD DEMSETZ (1968), o problema está nas justificativas utilizadas para a existência de regulação. Segundo o autor, os motivos invocados para submeter determinados setores à regulação não se sustentam sob o ângulo da teoria econômica.

Depois de criticar a teoria do monopólio natural e as justificativas tradicionais para a existência de regulação (necessidade de evitar a duplicação de infraestruturas e de disciplinar as "incertezas" que decorrem de relações de longo prazo, tal como as prestações de serviços tidas como utilities), H. DEMSETZ sustenta que "the rivalry of the open market place disciplines more effectively than do the regulatory processes of the commission". ${ }^{71}$ Se se duvida de tal conclusão, o autor sugere que "managements of utilities companies" "re-examine the history of their industry to discover just who it was that provided most of the force behind the regulatory movement". ${ }^{2}$

Esse desafio dá pista de qual, efetivamente, seria a razão por detrás da existência da regulação. Quando menos, a conclusão citada sugere que a regulação é incentivada pelas indústrias reguladas. Por isso, há quem afirme que é dele a primeira

\footnotetext{
${ }^{69}$ E por que essa necessidade se coloca? Uma explicação plausível parece envolver a circunstância de que a segurança é meio de evitar a desconfirmação da norma editada pela agência reguladora (isto é, impedir que a norma seja ignorada pelo regulado), o que aniquilaria a autoridade da agência. Aqui se alude diretamente às lições de TÉRCIO SAMPAIO FERRAZ JÚNIOR, tratadas em detalhes no item 2.2.2., $a$, infra.

${ }^{70}$ As variáveis, os critérios de pesquisa e os resultados desse estudo foram publicados no artigo "What Can regulators regulate? The case of Eletricity", originalmente publicado em Journal of Law and Economics, vol. 5 (Out. 1962). A versão utilizada neste trabalho foi publicada na coletânea The citizen and the State: essays on regulation. Chicago and London: The University of Chicago Press, p. 61-77.

${ }^{71}$ Why regulate utilities? In: STIGLER, George J. Chicago Studies in Political Economy. Chicago and London: The University of Chicago Press, 1988, p 278. Segundo GEORGE L. PRIEST, "Demsetz's article demonstrated that there were no conditions under which regulation by commission could be guaranteed to optimize social welfare." ("The origins of utility regulation and the "theories of regulation" debate". The Journal of Law \& Economics. vol. XXXVI, apr-1993, p. 299).

${ }^{72}$ Why regulate utilities? Ob. cit., p 278.
} 
sugestão quanto às "reais" razões da regulação por meio de comissões independentes. ${ }^{73}$ Embora H. DEMESETZ coloque em causa a explicação teórica da existência de regulação por comissões e indique a possibilidade de que seja outra a motivação que esteja por detrás da existência de regulação sob esse formato, não desenvolve uma teoria a respeito desses motivos. Isso é feito posteriormente por GEORGE J. STIGLER.

Depois dos trabalhos empíricos que demonstravam a ausência dos efeitos que deveriam advir da regulação, STIGLER desenvolve a tese de que "as a rule, regulation is acquired by the industry and is designed and operated primarily for its benefit" (1971). ${ }^{74}$

De acordo com a tese de STIGLER, o Estado é o único ente que detém poder coercitivo. Como tal, é capaz de determinar a movimentação de recursos e a adoção de decisões econômicas sem o consentimento das pessoas. Como consequência, esses poderes podem ser usados para ampliar a lucratividade de alguns setores econômicos.

$\mathrm{Na}$ medida em que as pessoas procuram promover seus próprios interesses de modo racional, haveria uma espécie de "mercado político", no qual as empresas poderiam adquirir determinados benefícios advindos da regulação. Os benefícios que o setor pode obter da instituição de regulação seriam quatro: (i) obtenção de subsídios e subvenções; (ii) instituição de barreiras de entrada no setor; (iii) regulação que atinja positivamente os produtos complementares ao setor econômico que busca a regulação e afete negativamente os produtos substitutos; (iv) fixação de preços.

Segundo STIGLER, "The industry which seeks political power must go to the appropriate seller, the political party", things a party needs: votes and resources". ${ }^{76}$

A tese do Autor foi inovadora porque contradisse as duas visões que, de acordo com o próprio STIGLER, eram então difundidas. Trata-se das idéias $(i)$ de que a regulação é instituída em favor do público em geral ou de uma subclasse desse público e (ii) de que o processo político não pode ser racionalmente explicado, eis que derivado de uma constante e imponderável mistura de forças.

\footnotetext{
${ }^{73}$ Essa é a opinião de GEORGE L. PRIEST ("The origins of utility regulation and the "theories of regulation" debate". Ob. cit., p. 298-299).

74 "The theory of economic regulation". The citizen and the State. Chicago and London: University of Chicago Press, 1975, p. 114.

75 "The theory of economic regulation". Ob. cit., p. 126.

76 "The theory of economic regulation". Ob. cit., p. 126.
} 
A primeira dessas visões tradicionais é contestada pela idéia central do trabalho de STIGLER: a regulação não se volta à obtenção de objetivos públicos, mas à criação de benefícios em favor de interesses específicos. A segunda delas é contestada porque o desenvolvimento da tese de STIGLER parte da premissa de que "sistemas políticos são racionalmente delineados e racionalmente utilizados". ${ }^{77}$ Desse modo, haveria uma espécie de utilização estratégica dos sistemas políticos por parte dos grupos de interesse e dos próprios responsáveis pela regulação, que resultaria na produção de regulação que lhes beneficiasse.

Os estudos de STIGLER foram aperfeiçoados por outros economistas. A esse respeito, merecem destaque os textos de SAM PELTZMAn (1976) ${ }^{78}$ e de GARY BeCKer $(1983) .^{79}$

Segundo o modelo de PeltzMan, a legislação redistribui riqueza e o comportamento adotado pelo legislador/regulador é dirigido para maximizar o seu suporte político. Assim, o legislador/regulador "will seek a structure of costs and benefits that maximizes political returns". ${ }^{80}$ Como resultado, os estudos concluem que a legislação e a regulação frequentemente beneficiam os grupos de interesse mais bem organizados (i.é, grupos menores e com preferências mais bem definidas), pois tais grupos teriam um suporte político mais efetivo a oferecer.

A teoria de STIGLER é tomada por BECKER sob outro ângulo. Enquanto os estudos de PELTZMAN privilegiavam o enfoque do legislador/regulador (que escolhem a política regulatória que maximiza o suporte político) e, a partir dele, "descobre" quais serão os grupos beneficiados pela regulação, BECKER examina o problema à luz da competição entre os grupos de interesse. Indica que a regulação favorável depende não só do que o grupo interessado na regulação tem a oferecer, mas da pressão que exerce sobre o legislador/regulador. O exame do exercício dessa "influência" não pode ser feito de modo

\footnotetext{
77 "The theory of economic regulation". Ob. cit., p. 115. A idéia pode ser identificada com a vertente teórica denominada public choice, tal como se examina em detalhes posteriormente (item 2.1.2, c, infra).

78 "Toward a more general theory of regulation". Chicago Studies in Political Economy. In: STIGLER, George J. (Ed.), Chicago: University of Chicago Press, 1988, p. 234-266 e "Theory of regulation after a decade of deregulation". Political participation and government regulation. Chicago: University of Chicago Press, 1998, p. 155-187.

79 "A theory of competition among pressure groups for political influence". Quarterly Journal of Economics. vol. 98 (3), ago. 1983, p. 371-400. A versão consultada para a elaboração do presente trabalho foi publicada em The foundations of regulatory economics. (vol. II, ROBERT B. EKELUND (Ed), Cheltenham: Edward Elgar, 1998, p. 173-202.

${ }^{80}$ SAM PETLZMAN, "Toward a more general theory of regulation”. Ob. cit., p. 256.
} 
isolado, mas depende da comparação com a pressão exercida pelos demais grupos de interesse presentes na sociedade. Assim, "politicians and bureaucrats are assumed to carry out the political allocations resulting from the competition among pressure groups." ${ }^{81} \mathrm{E}$, portanto, o que importa para determinar a "quantidade" de atividade regulatória que certo grupo receberá é a pressão que exerce sobre o regulador/legislador comparativamente aos demais grupos existentes na sociedade. ${ }^{82}$

Em termos sucintos: G. STIGLER busca, a partir de instrumentais da ciência econômica, explicar a existência da regulação. A partir deles, conclui que, tal qual na economia, os agentes políticos também agem racionalmente, com vistas à maximização de seus próprios interesses. Por isso, em regra, a regulação prestar-se-ia aos setores regulados. Os estudos de S. PELtZMAn aperfeiçoam os de StiGLER, ofertando explicação para entender por que normalmente são os setores regulados os beneficiados pela regulação. $\mathrm{Na}$ medida em que PeltZMAn conclui que são os grupos coesos, com menor número de integrantes e com interesses mais bem definidos que têm mais a oferecer ao legislador/regulador, é evidente que a regulação tenderá a beneficiar os regulados (grupo que se reveste daquelas características) em detrimento, por exemplo, do grupo de usuários. Por fim, G. BECKER complementa esses trabalhos anteriores, explicando, também em termos econômicos, as razões pelas quais haveria regulação que poderia beneficiar grupos diferentes do setor regulado. Na medida em que os grupos de interesse competem entre si, a regulação beneficiará não só aquele que tem mais a ofertar ao legislador/regulador, mas aquele que exerce, de modo mais efetivo, pressão sobre o editor das normas.

As teorias de Stigler e Peltzman cogitam de uma barganha entre, de um lado, grupos de interesse e, de outro, o legislador/regulador. Nesse processo, o legislador/regulador seria induzido a promover fins privados mediante o emprego dos poderes públicos que detém com vistas a obter suporte eleitoral (no caso do regulador setorial, um eventual suporte profissional) posterior. Para BECKER, o regulador é uma espécie de árbitro no embate entre grupos de interesse que visam à obtenção, para si, de bens públicos. ${ }^{83}$

\footnotetext{
${ }^{81}$ GARY BECKER, A theory of competition among pressure groups for political influence", Ob. cit., p. 198.

${ }^{82}$ Acerca desses desdobramentos, confira-se a síntese de W. K.VISCUSI e OUTROS, Economics of regulation and antitrust. 4th ed., Cambridge: MIT Press, 2005, p. 372 e ss.

${ }^{83}$ JERRY L. MASHAW cita os dois ângulos da teoria dos grupos de interesse sem identificar quem seriam os teóricos de cada uma das vertentes (Greed, Chaos and Governance: using public choice to improve Public Law. New Haven and London: Yale University Press, 1997, p. 35).
} 


\section{a) As críticas dirigidas à explicação econômica do problema da captura}

A explicação econômica do problema da captura pode ser submetida a algumas críticas internas à própria teoria. Uma delas é a impossibilidade de a teoria explicar os movimentos de desregulação. Se a regulação produz efeitos positivos para grupos de interesse organizados (tal como o são os regulados), por que haveria espaço para movimentos de desregulação? Por que interesses bem organizados (como os das empresas já existentes e submetidas à regulação) cederiam espaço para interesses não-organizados ou pouco organizados como os dos consumidores (beneficiados com o movimento de desregulação)? Mais: por que os mercados submetidos à desregulação não seriam, posteriormente, re-regulados? $?^{84}$

A teoria econômica dos grupos de interesse também não fornece, por ela mesma, explicação para a aprovação de regulação que visa à tutela de interesses gerais, tal como é o caso da regulação de proteção ambiental. Como afirma JERRY L. MASHAW, "The interst group theorists seemed to have forgotten that political parties and aspiring presidents might simply bypass entrenched interests and go directly to the electorate". ${ }^{85}$ Por certo, a aprovação de normas de proteção ambiental teve a influência de grupos de interesse. ${ }^{86}$ A questão é que, para a teoria econômica dos grupos de interesse, esse tipo de grupo de pressão nunca deveria se formar: para além do tamanho do grupo de beneficiados ser muito grande (o que dificultaria a organização), os seus integrantes não se apropriariam

\footnotetext{
${ }^{84}$ As duas primeiras questões são colocadas por MiCHAEL E. LEVINE, em "Revisionism revised? Airline Deregulation and the Public Interest" (Law and Contemporary Problems, vol. 44, abr. 1981, p. 179-185) e a última é por ele colocada em "Regulation, the market and interest group cohesion: why airlines were not reregulated" (New York University Law and Economics Working Papers. Paper 80, 2006, disponível em: http://lsr.nellco.org/nyu/lewp/papers/80, acessado em 31.03.2008). Segundo LEVINE, a resposta às questões depende do refinamento da teoria econômica dos grupos de interesse e a consideração de duas circunstâncias de extrema relevância: $(i)$ o "aproveitamento" dos benefícios gerados pela regulação depende de um espaço discricionário conferido ao regulador que esteja protegido do escrutínio público (slack). Os movimentos de desregulação normalmente ocorrem em momentos críticos ou quando se traz a público a atuação do regulador. Assim, a desregulação se coloca quando há o desaparecimento do slack e, portanto, da possibilidade de que a regulação seja "apropriada" pelos grupos de interesse; (ii) depois, o movimento de desregulação forma, rapidamente, outros grupos de interesse bem organizados (por exemplo, as empresas entrantes) que podem fazer frente aos interesses do anterior setor regulado e impedir o retorno ao status quo ante. (Regulation, the market and Interest Group cohesion: why airlines were not reregulated". Ob. cit., passim).

${ }^{85}$ Greed, Chaos and Governance: using public choice to improve Public Law. Ob. cit., p. 33

${ }^{86}$ Mesmo antes do desenvolvimento da teoria econômica dos grupos de interesse, era difundida a idéia de que havia, quando menos, duas categorias de grupos de interesse. Os grupos de interesse formados em defesa de uma causa e os grupos de interesse ligados a um setor. Os primeiros, em regra, não envolveriam interesses econômicos. Ligados a uma causa, representariam uma crença ou uma questão de princípio defendida por seus membros. A respeito dessa distinção, confira-se GrANT JORDAN, WILliam A MALONEY e LYNN G. BENNIE, "Les groupes d' intérêt public". Pouvoirs: Revue Française d'Études Constitutionnnelles et Politiques. vol.79, Paris, 1996, p. 69-70.
} 
individualmente dos resultados obtidos pela aprovação do texto normativo e, portanto, não teriam incentivos em lutar para a sua obtenção.

Essa crítica revela uma das ambiguidades que se identifica na teoria econômica dos grupos de interesse: ela não define se são mais relevantes os grupos grandes (com maior número de participantes) ou pequenos (com quantidade menor de integrantes). Embora os estudos supracitados mencionem que grupos menores são mais coesos, mais organizados e têm mais a oferecer na barganha com o regulador/legislador, não se pode olvidar que, como destacado na teoria de G. J. STIGLER, a moeda para aquisição da regulação é "dinheiro e votos". E se, talvez, dinheiro seja mais fácil de ser obtido em grupos menores, votos são obtidos com maior facilidade quando são defendidos interesses vinculados a grupos maiores.

JERRY L. MASHAW identifica, ainda, outra ambiguidade derivada da posição do legislador/regulador em face dos grupos de interesse. Se, para uma vertente, o legislador/regulador é parte de um processo de barganha, que exerce poderes públicos em favor de interesses privados para, em troca, obter benefícios pessoais (eleitorais ou profissionais); para outra, o legislador/regulador é um árbitro entre os grupos de interesse que se embatem pela obtenção dos bens públicos. Segundo J. L. MASHAW, nessa segunda vertente, a promoção do bem-estar geral por meio da política re-emerge como possibilidade real. ${ }^{87}$ Ocorre que esse "ressurgimento" contraria a ideia básica da explicação econômica para a existência de regulação (a afirmação de que, em regra, ela se presta a beneficiar os regulados).

Também é destacada a limitação da teoria econômica dos grupos de interesse para identificar antecipadamente os problemas sobre os quais se debruça. No que concerne a relações já colocadas e problemas já identificados, a teoria fornece explicação suficiente para identificar o grupo beneficiado pela regulação. Porém, não tem a mesma aptidão para examinar situações em que o comprometimento da regulação em favor de certo grupo de interesse ainda não ocorreu. Daí MASHAW afirmar que, embora a teoria seja adequada para exame de situações ex post factum, fornece poucos recursos para se levar a efeito análises ex ante acerca do eventual comprometimento da regulação. ${ }^{88}$

\footnotetext{
${ }^{87}$ Greed, Chaos and Governance: using public choice to improve Public Law. Ob. cit., 1997, p. 35.

${ }^{88}$ JERrY L. MASHAW. Greed, Chaos and Governance: using public choice to improve Public Law. Ob. cit., p. 34 .
} 
Por fim, e se se pretende tratar a relação entre legislador/regulador e regulados como um mercado, ter-se-ia um "mercado altamente imperfeito", pois o legislador/regulador (equivalente ao fornecedor) deteria um poder próximo ao de monopólio e, diante disso, teria espaço para tutelar não só os estritos interesses privados, mas também interesses diversos, tais como aqueles decorrentes de suas posições ideológicas. $^{89}$

\section{b) Os novos aportes para o exame da teoria da captura}

Conforme destacado no item anterior, do modo como formulada inicialmente, a explicação econômica para a existência de regulação (que redunda na detecção de ocorrência de captura) pode ser submetida a diversas contestações. Todas as críticas expostas podem ser aglutinadas em uma só idéia: rigorosamente, a teoria não explica como se dá a relação entre os diversos sujeitos envolvidos no processo de regulação, assim como não dá respostas satisfatórias sobre os mecanismos de que se valem os reguladores na conformação dos seus interesses com aqueles dos grupos de interesse que buscam obter os benefícios da regulação. Novos aportes teóricos sobre o problema permitem suprir esse "espaço" deixado pela explicação econômica da regulação. ${ }^{90}$

Primeiro, alguns desses novos aportes permitem que se construam modelos explicativos em que a ideologia (ou seja, a crença de se promover o interesse público propriamente dito) é considerada nos estudos sobre a tomada de decisões políticas. A partir deles, a construção de modelos econômicos deve levar esse dado em conta, tentando identificar as circunstâncias em que a ideologia desempenha um papel relevante. ${ }^{91}$

Depois, valendo-se da "teoria da agência" e dos problemas informacionais que ela permite identificar, os estudos sobre problema da captura permitem compreender melhor o funcionamento do processo de regulação e os "espaços" deixados ao regulador para que possa agir em favor de grupos de interesse. Em termos sintéticos, a teoria da agência envolve os casos em que dois sujeitos (um "principal" e um "agente") firmam um contrato, por meio do qual um deles (o principal), proprietário de dado bem ou titular de

\footnotetext{
${ }^{89}$ Sobre o papel da ideologia no estudo do problema da captura, confira-se JOSEPH KALT e MARK ZUPAN. "Capture and ideology in the economic theory of politics". American Economic Review. vol. 74 (3), 1984, p. 279-300.

${ }^{90}$ MiCHEL E. LEVINE e JENNIFER L. FORRENCE, "Regulatory capture, public interest, and the public agenda: toward a synthesis". Journal of Law, Economics, and Organization. vol. 6 (Special Issue), 1990, p. 170.

${ }^{91}$ JOSEPH KALT E MARK ZUPAN. "Capture and ideology in the economic theory of politics". Ob. cit., p. 298.
} 
certo direito, confia a outro (o agente) a execução de determinados serviços. Quando há delegação da atividade, também se transfere ao agente o poder de tomada de decisões, que produzirão efeitos sobre a propriedade e(ou) sobre o direito de titularidade do principal. Nessa relação, caberia ao agente, no momento da decisão, optar por aquela que melhor tutelasse os interesses do principal. ${ }^{92}$ Porém, é exatamente aí que o problema se coloca: por um lado, o agente tem interesses próprios, que não necessariamente coincidem com os interesses do principal; por outro, o principal não dispõe (de modo imediato e a custo zero) das informações necessárias para que possa conhecer com precisão a atuação do agente e, portanto, controlá-lo. Em outras palavras, a diferença entre os interesses do principal e os do agente e a assimetria informacional existente na relação entre eles permitem que o agente se desvie do objetivo que deveria visar por meio de sua atuação.

Mediante o uso da "teoria da agência", é possível separar as diferentes relações que se estabelecem no momento do exercício da regulação. Até aqui, as teorias expostas trataram indistintamente a regulação que deriva da atuação do Poder Legislativo e a regulação advinda da Administração Pública (especialmente das agências reguladoras). A teoria da agência permite visualizar, com maior clareza, que legisladores e reguladores administrativos (integrantes das agências reguladoras, por exemplo) não têm interesses necessariamente coincidentes, o que permite desdobrar as relações existentes quando da edição de determinada regulação. Enquanto o objetivo visado pelos legisladores é garantir a reeleição, os objetivos dos burocratas são outros. Envolvem, por exemplo, a obtenção de alguma facilidade derivada do exercício do cargo ou, mesmo, uma vantagem pecuniária futura, como a maximização de sua posição profissional em momento posterior ao exercício da regulação. ${ }^{93}$

\footnotetext{
${ }^{92}$ Michael C. JenSEN e WiLliam H. MeCKLing. "Theory of the firm: Managerial behavior, agency costs, and ownership structure". Journal of Financial Economics,vol. 3 (4), Octobre- 1976, p. 305-360. A versão consultada é a que foi disponibilizada na Internet, no seguinte endereço: http://ssrn.com/abstract=94043, acessado em 01.10.2008. Para uma revisão ampla da literatura sobre teoria da agência, KATHLEEN M. EISENHARDT. "Agency theory: An assessment and review". Academy of Management. The Academy of Management Review. vol. 14 (1), jan-1989, p. 57-74. Para uma abordagem específica acerca da intervenção do Estado no domínio econômico, confira-se o texto de ADAM PRZEWORSKI, "Sobre o desenho do Estado: uma perspectiva agent x principal" In: BRESSER-PEREIRA, Luiz e SPINK, Peter (org.). Reforma do Estado e Administração Pública Gerencial. $4^{\mathrm{a}}$ ed. Rio de Janeiro: FGV, 2001, p. 39-71.

${ }^{93}$ Michel E. LeVINE e JENNIFER L. ForRENCE, "Regulatory capture, public interest, and the public agenda: toward a synthesis". Ob. cit., p. 168. T. MAKKAI e J. BRAITHWAITE colocam em dúvida se a busca de futura colocação profissional é, de fato, um objetivo almejado pelo regulador a ponto de comprometer o exercício da regulação. Segundo esses autores, há "little support for the theory that regulatory enforcement is under the hegemony of the private interests from which so many regulators come - or to which they hope to go. The deceptively simple idea of the revolving door provides an unsatisfactory basis for analyzing such hegemony". ("In and out of the Revolving Door: making sense of regulatory capture". In: BALDWIN, Robert; SCOTT,
} 
Nos limites do presente trabalho, é necessário se examinar as relações do regulador. O regulador administrativo só tem lugar para atuar quando recebe uma delegação legislativa para tanto. O legislador fixa os standards gerais de determinada política pública e o regulador fixará as regras específicas que concretizam esses standards e atingem os objetivos visados pelo legislador. ${ }^{94}$ Nessa justa medida, instala-se uma regulação principal-agente entre o Congresso (principal) e o regulador (agente). Diante da diferença de objetivos de um e de outro e da assimetria informacional que se estabelece entre o Congresso e o regulador, este pode vir a se afastar das políticas definidas por aquele. $^{95}$

De toda a forma, e no contexto de ações estritamente racionais, não é de se esperar que a formulação das políticas públicas seja tida como genuína tutela do "interesse público". Segundo MCCUBbins, Noll e WeINGAST, os políticos seriam o canal por meio do qual os grupos de interesse influenciam a agência. Portanto, o eventual alinhamento das agências com as políticas fixadas pelo Congresso pode, por vezes, significar a formulação de regulação favorável à determinada indústria. ${ }^{96}$

Parece ser possível explicar a multiplicidade de relações que se estabelece na edição da regulação por uma sucessão de relações "agente-principal”, em que o papel do principal é, em última medida, ocupado pelos eleitores. São eles que outorgam poderes decisórios ao legislador. Porque nem sempre os objetivos dos eleitores (da sociedade civil como um todo) coincidem com os interesses pessoais do legislador e porque há uma intensa dificuldade na obtenção das informações necessárias para o controle do legislador, ele pode, eventualmente, editar políticas que não beneficiem o público em geral, mas um grupo de interesse coeso e determinado (um setor econômico em busca de regulação, por exemplo). Em outras palavras: ao receber a delegação dos eleitores, duas opções se colocam para o legislador. Ou ele tutela os interesses do principal por meio de formulação de políticas que atendam ao interesse geral, ou ele se desvia desses interesses (porque as

Colin; e HOOD, Christopher (Ed.). A reader on regulation. New York: Oxford University Press, 1998, p. 189).

${ }_{94}$ Tal como afirma FloRiano MARQUES Neto, a legislação define, em linhas gerais, as políticas públicas (somatório de políticas de Estado e políticas de Governo) e a implantação concreta dessas políticas se dará por meio de políticas regulatórias, que são levadas a efeito pelo regulador (Agências reguladoras: instrumentos do fortalecimento do Estado. São Paulo: ABAR, [s/d], p. 38-40)

${ }^{95}$ Mathew D. McCubbins, Roger G. Noll e BARRY R. Weingast. "Administrative Procedures as instruments of political control". In: JOSKOW, Paul L. Economic Regulation. Cheltenham and Northampton: Elgar, 2000, p. 88-122.

${ }^{96}$ Mathew D. McCubbins, Roger G. Noll e Barry R. Weingast. "Administrative Procedures as instruments of political control". Ob. cit., p. 119. 
condições para tanto estão reunidas) e tutela os interesses que lhe tragam futuros benefícios privados.

Mas o legislador também pode, em vez de editar as regras específicas, delegar tal competência a uma agência reguladora. ${ }^{97}$ Nessa situação, ele fixa os standards que a agência deve seguir (standards esses que podem ser estabelecidos na tutela de interesses gerais ou na tutela de interesses especiais). Em tal ocasião, ao mesmo tempo em que é agente na relação com os eleitores, o legislador é principal na relação com os reguladores administrativos. Nessa última relação, como não há coincidência entre os interesses do legislador e do regulador e o problema informacional se faz presente, o regulador pode se afastar da política definida pelo legislador. Aí se abre uma gama de opções. Basicamente, o standard fixado pelo legislador pode ser de duas ordens: para a tutela do interesse geral ou para a tutela do interesse especial. Nas duas situações, o regulador pode cumprir o standard ou dele se desviar (porque, tal como salientado, há condições para isso), surgindo-lhe quatro opções: em face de standard que tutela o interesse geral, pode cumpri-lo ou dele se desviar; em face de standard que tutela interesses especiais, podem cumpri-lo ou dele se desviar (em homenagem a sua ideologia pessoal, por exemplo). Em termos sintéticos:

\footnotetext{
${ }^{97}$ Reportando-se à obra de MORRIS FIORINA, MiCHAEL E. LEVINE e JENNIFER L. FORRENCE destacam que a delegação pode ser favorável ao legislador porque "they can simultaneously avoid responsibility for the cost of regulation while claiming credit for the benefits" ("Regulatory Capture, Public Interest, and public agenda". Ob. cit., p. 180, nota 18)
} 


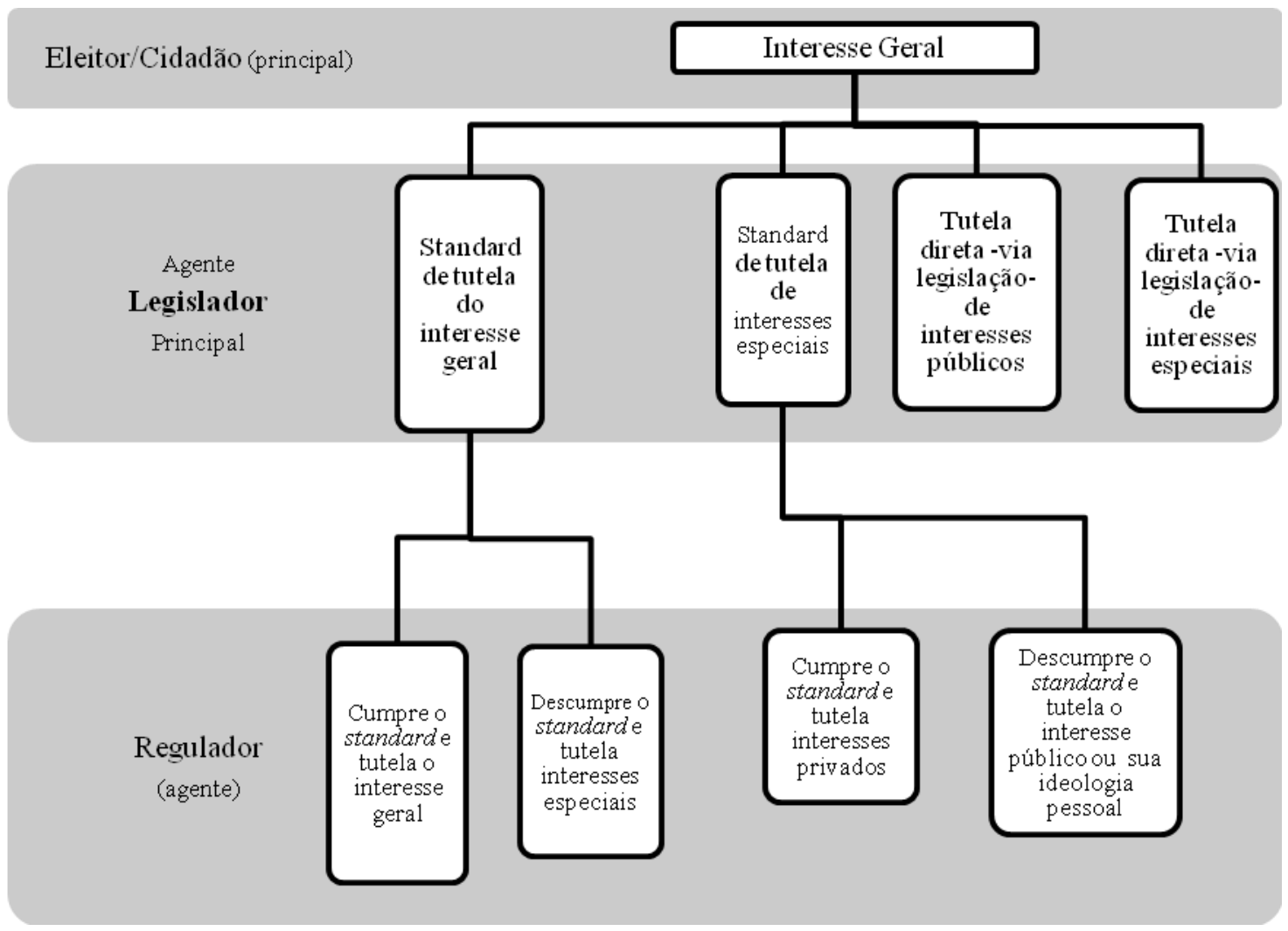

Por meio da utilização da teoria da agência, consegue-se, também, acomodar a tutela do interesse público no processo de regulação. Nesse sentido é a preocupação de Michel E. LEvine que, depois de ter explorado a hipótese de que há movimentos de regulação (e(ou) de desregulação) que acabam por tutelar o interesse público ${ }^{98}$, tenta desenvolver um modelo que acomode a tutela do interesse geral, a tutela de interesses especiais e a busca de objetivos diversos pelo regulador (que podem não coincidir nem com o interesse geral e nem com o interesse especial, tal como ocorre, por exemplo, com as decisões guiadas pela ideologia pessoal do sujeito). Esse modelo tem duas grandes variáveis: (i) os custos de monitoramento da atuação do responsável pelo exercício da regulação e (ii) a motivação do responsável pela regulação. Na síntese de MiCHAEL E. LEVINE e JENNIFER L. FORRENCE, a pergunta é: "how expensive is it for one political actor to monitor a decision by another actor, and what is it that political actors try to maximize?"99

\footnotetext{
98 "Revisionism revised? Airline deregulation and the public interest." Ob. cit., p. 179-195.
}

99 "Regulatory Capture, Public Interest, and public agenda". Ob. cit., p. 173. 
Com efeito, os reguladores tentam se valer de uma retórica de interesse público para justificar suas ações, isto é, "regulators have adopted ideological language and public-interest rethoric in an effort to generate general support or tolerance for actions or policies that cannot be fully monitored". ${ }^{100}$ Por isso, deve haver um esforço para tentar identificar três situações distintas: (i) as situações em que o regulador age, de fato, com vistas ao interesse geral; (ii) as ocasiões em que o regulador age tendo em mira outros interesses (other-regarding) e acredita que os seus atos são publicamente desejáveis (caso da ideologia); e (iii) os casos em que o regulador está na tutela dos seus interesses especiais, que envolvem, muito comumente, a tutela a interesses especiais de grupos específicos. O modelo cunhado por MichAEL E. LEVINE tenta acomodar essas situações, combinando considerações sobre a motivação do regulador e os custos de monitoramento (o espaço de liberdade - slack - que os custos de monitoramento acabam por deixar para o regulador). Nas palavras do autor,

We postulate that regulators are either self-regarding or other-regarding. When they are self-
regarding, they will pursue general-interest policies if there is a little or no slack, or be captured if
sufficient slack is present. When they are other-regarding, they will pursue policies that cannot get
them general support, either because the polity does not accept the view of it own interest that
regulator holds or because information costs prevent a polity that would favor a policy from
understanding and supporting it. This other-regarding and costly regulatory behavior is what we
call Burkean, and slack is a necessary but not sufficient condition for its existence.
Burkean behavior may or may not produce policies that are in the general interest. It will produce
general-interest policies when the other-regarding preferences of the regulator favor policies that
would be supported by the general polity if only slack could somehow be eliminated. On the other
hand, an other-regarding Burkean regulator, who favors for ideological reasons policies that the
general polity would not ratify (because they not share her vision of the general good), imposes
her own preferences on the polity for "public", rather than capture, reasons.

Os novos aportes sobre o problema da captura acabam por se valer de outros instrumentos (teoria da agência, por exemplo), que tornam mais claros os processos políticos de formação da regulação, permitindo diferenciar o papel dos reguladores e dos legisladores, bem como tentar identificar as situações em que é mais provável que se tenha regulação que tutele o interesse público (em vez de uma situação de captura).

\section{c) As críticas dirigidas aos pressupostos teóricos da explicação econômica do problema da captura}

A explicação econômica que conduz à identificação do problema da captura

\footnotetext{
100 "Regulatory Capture, Public Interest, and public agenda". Ob. cit., p. 180.

101 "Regulatory Capture, Public Interest, and public agenda". Ob. cit., p. 183.
} 
pode ser inserida em um movimento teórico mais amplo denominado public choice. ${ }^{102} \mathrm{Tal}$ como salienta MARIA ROSARIA FERRARESE, a escola teórica da public choice fornece uma “chave de leitura" para o exame do processo de tomada de decisões públicas. ${ }^{103}$ Segundo a public choice, não seria possível cindir o exercício de funções políticas ou públicas e a perseguição de interesses concretos (especialmente, o interesse concreto do responsável pela edição da legislação e/ou da regulação). O resultado das escolhas públicas vem interpretado a lume da interação entre os reguladores/legisladores (agentes públicos) de um lado e, de outro, os atores privados. Porém, ambos se valem de estratégias racionais (e economicamente orientadas) nessa interação.

O referencial teórico da public choice é o individualismo metodológico, imbuído de referências microeconômicas: o móvel natural dos indivíduos (inclusive dos agentes públicos) são os interesses pessoais e a maximização do próprio bem-estar. ${ }^{104}$

Embora as críticas dirigidas à teoria econômica da captura sejam parcialmente supridas pelos estudos posteriores, não se pode deixar de anotar dois pontos. Primeiro, os novos aportes também têm como referencial teórico as idéias da public choice. ${ }^{105}$ Depois, há outro grupo de críticas que coloca em causa os pressupostos de que parte a explicação econômica do problema da captura, isto é, questiona o pressuposto teórico que está por detrás da escola da public choice e da teoria econômica da regulação

\footnotetext{
${ }^{102}$ Incluem a explicação econômica da captura nesse movimento mais amplo, MARIA RoSARIA FERRARESE, Diritto e mercato: il caso degli Stati Uniti. Torino: G. Giappichelli Editore, 1992, p. 362-377 e JERRY L. MASHAw, Greed, Chaos and Governance: using public choice to improve Public Law. Ob. cit., p. 10-21.

${ }^{103}$ São expressões desse movimento teórico KENETH J. ARROW (Social Choice \& individual values, 2nd ed., New Haven and London: Yale University Press, 1951), cujo teorema é utilizado nas explicações acerca do desenvolvimento de votações; ANTHONY Downs (An economic theory of democracy. Boston: AddisonWesley, 1957), que formula explicação para o funcionamento das instituições democráticas com base na conveniência eleitoral; JAMES M. BUCHANAN \& GORDON TULLOCK (The calculus of consent: logical foundations of constitucional democracy. Michigan: The University of Michigan Press, 1962), que reformulam a teoria de DOWNS; e WILLIAM A. NISKANEN JR. (Bureaucracy \& Representative Government. New Brunswick and London: Aldine Transaction, 1971), segundo quem os burocratas adotam condutas racionais que visam a ampliar o poder (salário e prestígio) que detêm. Daí ter formulado um modelo de maximização pautado no orçamento.

${ }^{104}$ MARIA RoSARIA FERRARESE, Diritto e mercato: il caso degli Stati Uniti, cit., p. 362. JERRY L. MASHAW entende que as contribuições da public choice podem ser desdobradas em duas teorias: a teoria da votação e a teoria dos grupos de interesse (JERRY L. MASHAW, Greed, Chaos and Governance: using public choice to improve Public Law. Ob. cit., p. 10-21). No presente trabalho, interessa o segundo desses desdobramentos teóricos.

${ }^{105}$ Somente como exemplo, destaque-se que MiChAEL E. LEVINE e JENNIFER L. ForRenCE expressamente consignam que o modelo é construído a partir das ideias de DOWNS e OLSON, somadas às elaborações da teoria da agência e da teoria da informação ("Regulatory Capture, Public Interest, and public agenda". Ob. cit., p. 183). Quanto à utilidade da public choice, confira-se JERRY L. MASHAW, "The economics of politics and the understanding of public law". Chicago-Kent Law Review. vol. 65, 1989, p. 122-160.
} 
(sede de identificação do problema da captura). ${ }^{106}$ Esta parte do trabalho pretende apresentar tais críticas.

Inicialmente, deve-se destacar que a tese de STIGLER é contestada por seus próprios pares. Ainda que concorde com a teoria de STIGLER e tente oferecer soluções que a aprimorem, POSNER contesta a aplicação das conclusões de STIGLER para explicar a existência de toda e qualquer regulação. Segundo POSNER, "várias características do direito e das políticas públicas desenhadas para manter um sistema de mercado são mais plausíveis se explicadas através de referência a um amplo interesse social em eficiência do que através de referência aos desenhos definidos por grupos de interesse restritos."

A crítica formulada por POSNER foi rebatida por STIGLER ${ }^{108}$, explicitando o pressuposto teórico de sua construção. Segundo ele, as colocações de PoSNER dão a entender que há duas explicações para a regulação (uma fundada na prevalência de interesses regulados e outra fundada no interesse público). Porém, segundo STIGLER, ele pretende demonstrar que as duas teorias são uma só e que podem ser descritas como a tendência de as pessoas maximizarem os seus próprios interesses (utility-maximizing theory). Assim, ainda quando haja regulação em favor do público em geral, ela será expressão da maximização de interesses de alguns indivíduos (ainda que em maior número).

A explicação adicional formulada por STIGLER torna mais clara a ideia que perpassa a elaboração da teoria da captura: indivíduos maximizam seus próprios interesses. Legisladores e reguladores não são diferentes. Associadas à noção de maximização dos próprios interesses, estão outras duas: $(i)$ os agentes atuam racionalmente na tutela de seus próprios interesses; (ii) os agentes atuam individualmente e de modo atomizado. ${ }^{109}$

\footnotetext{
106 Tal como identifica MARIA RoSARIA FERrARESE, R. D. TOllison usa, de modo intercambiável, as expressões "public choice" e "teoria econômica da legislação" (Diritto e mercato: il caso degli Stati Uniti. Torino: G. Giappichelli Editore, 1992, p. 363).

107 “Teorias da regulação econômica”. In: MATTOS, Paulo (Coord.). Regulação econômica e democracia: o debate norte-americano. Trad. de Mariana Mota Prado, São Paulo, Editora 34, 2004, p. 67.

108 "The theory of economic regulation". Ob. cit., p. 137-138.

${ }^{109}$ Conforme afirma STIGLER, "we live in a world of reasonably well-informed people acting intelligently in pursuit of their self-interests". ("Economics or Ethics?” The Tanner Lectures on Human Values. Disponível em: www.tannerlectures.utah.edu/lectures/stigler81.pdf, último acesso em 20.10.2007, p. 190). Esse é, nas palavras de HEBERT A. SimON, o homo economicus tradicional, ou seja, "This man is assumed to have knowledge of the relevant aspects of his environment which, if not absolutely complete, is at least impressively clear and voluminous". ("A behavioral model of rational choice". The Quartely Journal of Economics. vol. 69 (1), 1955, p. 99). Ao mesmo tempo, "He is assumed also to have a well-organized and stable system of preferences, and a skill in computation that enables him to calculate, for the alternative
} 
Ocorre que nem sempre os indivíduos agem a partir dessas premissas.

Primeiro, há de se destacar que, ao lado do agir racional, há ações que seguem outras ordens de orientação. Para a explicação dessa diferença, recorre-se às categorias weberianas de determinação da ação social. Segundo WEBER,

A ação social, como toda ação, pode ser determinada: 1) de modo racional referente a fins: por expectativas quanto ao comportamento de objetos do mundo exterior e de outras pessoas, utilizando essas expectativas como "condições" ou "meios" para alcançar a fins próprios, ponderados e perseguidos racionalmente, como sucesso; 2) de modo racional referente a valores: pela crença consciente no valor - ético, estético, religioso ou qualquer seja sua interpretação absoluto e inerente a determinado comportamento como tal, independentemente do resultado; 3 ) de modo afetivo, especialmente emocional: por afetos ou estados emocionais atuais; 4) de modo tradicional: por costume arraigado. ${ }^{110}$

Rigorosamente, é possível afirmar que a conduta destinada à maximização de interesses individuais envolve ponderação entre os meios necessários ao alcance desse fim e a realização do "autointeresse". Assim, e a partir das categorias weberianas, pode-se afirmar que se trata de um tipo de ação social determinada de modo racional referente a fins. Isso torna claro dois dados relevantes. Primeiro, nem toda ação social é determinada por critérios racionais (há condutas determinadas pela emoção e pela tradição). Segundo, condutas de maximização do autointeresse não esgotam as categorias de ação pautadas em critérios racionais. Ao lado das ações racionais referentes a fins, há as ações racionais referentes a valores.

Além disso, e embora as condutas que maximizam a utilidade individual possam ser incluídas na categoria de condutas racionais orientadas a fins, também não é possível afirmar que elas esgotam essa categoria de ação social. Isso porque a maximização da utilidade individual não é o único objetivo a que pode se dirigir uma ação social racional referente a fins. Ao lado desse, os sujeitos podem agir racionalmente movidos por finalidades diversas da prevalência dos interesses individuais.

AMARTYA SEN, depois de afirmar que ADAM SMITH admitia uma diversidade de motivações ${ }^{111}$ para o comportamento humano, indica que "The demands of rationality need not be geared entirely to the use of only one of these motivations (such as

courses of action that are available to him, which of these will permit him to reach the highest attainable point on his preference scale." (“A behavioral model of rational choice”. Ob. cit., p. 99).

${ }_{110}^{110}$ Economia e sociedade. vol. 1, Ob. cit., p. 15.

111 Além do "amor-próprio (que pode ser reconduzido à ideia de autointeresse), "prudência", "simpatia", "generosidade" e "espírito público" também influenciariam a conduta humana (AMARTYA SEN, "Rationality and social choice”. The American Economic Review, vol. 85 (1), 1995, p. 15). 
self-love), and there is plenty of empirical evidence to indicate that the presumption of uncompromising pursuit of narrowly defined self-interest is as mistaken today as it was in Smith's time". ${ }^{112}$ Dessa forma, assim como se deve evitar pensar que todos os indivíduos (e os servidores públicos em particular) sempre visam à realização de fins sociais e públicos, também é importante evitar a assunção de que todos sempre estão constante e exclusivamente motivados pelo autointeresse individual. ${ }^{113}$

Note-se que isso não significa negar a existência de condutas autointeressadas, ${ }^{114}$ mas apenas consignar que, ao lado desse tipo conduta, podem existir outras tantas, igualmente racionais e orientadas a fins que visem a outros objetivos que não à realização do autointeresse.

Finalmente, mesmo quando motivadas pelo autointeresse, as decisões podem ser submetidas a certas limitações, que impedem que essa tutela seja alcançada.

Por um lado, há limitações gerais que incidem sobre todo o processo decisório. ${ }^{115}$ Envolvem o fato de que (i) o volume de informações à disposição do indivíduo é limitado; (ii) a capacidade de processamento das informações também é limitada. Nas palavras de Douglass C. NORTH,

If political and economic markets were efficient (i.e, there were zero transaction costs) then the choices made would always be efficient. That is the actors would always possess true models or if they initially possessed incorrect models the information feedback would correct them. But that version of the rational actor model simply led us astray. The actors frequently must act on incomplete information and process the information that they receive through mental constructs that can result in persistently inefficient paths. ${ }^{116}$

\footnotetext{
112 AMARTYA SEN, "Rationality and social choice". Ob. cit., p. 15. Quando trata da motivação dos agentes, Douglass NORTH adota entendimento que pode ser alinhado ao de AMARTYA SEN. Segundo NORTH, "The broad range of human actions characterized by such activities as the anonymous free donation of blood, the dedication to ideological causes such as communism, the deep commitment to religious precepts, or even the sacrificing of one's life for abstract causes could all be dismissed (as many neoclassical economists dismiss them) if they were isolated events. But obviously they are not ant they must be taken into account if we are to advance our understanding of human behavior".(Institutions, institutional change and economic performance. Ob. cit., p. 25-26).

${ }^{113}$ AMARTYA SEN, "Rationality and social choice". Ob. cit., p. 15-16. Em sentido similar, HA-JOON CHANG, "The economics and politics of regulation". Cambridge Journal of Economics. vol. 21, 1997, p. 723-724.

114 “Comportamento econômico e sentimentos morais". Sobre Ética e Economia. Trad. de Laura Teixeira Motta, São Paulo: Companhia das Letras, p. 34-35.

${ }^{115}$ De modo sintético, pode-se afirmar que o processo de escolha do agente autointeressado envolve, inicialmente, a criação de alternativas e, posteriormente, a tomada de decisão, com vistas à maximização dos próprios interesses (C. MANTZAVINOS, Individuals, institutions and markets. Cambridge: Cambridge University Press, 2001, p. 46-47). Nos dois momentos, incidem as limitações aqui tratadas. Isto é, no momento em que o indivíduo elabora as alternativas, como no momento de deliberação (em que o sujeito escolhe entre as alternativas que anteriormente elaborou).

116 Institutions, institutional change and economic performance. Ob. cit., p. 8. Quanto à limitação da racionalidade, PAULO GALA destaca que NORTH, nesta obra, conectava essa limitação à restrição da
} 
Por outro, existem limitações específicas (isto é, vinculadas à situação concreta em que a decisão será tomada). Elas são de duas ordens: (i) instituições; e (ii) organizações.

Para Douglass NORTH, as instituições são "the rules of the game in a society"117, que abrangem restrições formais e informais. Para VICTOR NEE, instituições são "a system of interrelated informal and formal elements-custom, shared beliefs, conventions, norms, and rules-governing social relationships within which actors pursue and fix the limits of legitimate interests.". 118

A partir dos dois conceitos, pode-se afirmar que instituições modelam e restringem a conduta dos indivíduos. Assim, mesmo na busca do autointeresse, a existência de instituições pode gerar constrangimentos às condutas dos indivíduos, impedindo a maximização. Por sua vez, a presença de organizações que atuam ao lado do agente econômico pode levar a alterações nas condutas por ele adotadas que nem sempre serão pautadas por critérios estritamente racionais. ${ }^{119}$

Ocorre que, além das limitações relacionadas com a adoção de condutas racionais (até aqui expostas), também há as limitações que derivam da impossibilidade de

\footnotetext{
"capacidade computacional" dos indivíduos no processamento das informações. Porém, em obra posterior, teria adicionado mais um dado. A limitação da racionalidade não deriva somente das restrições inerentes à capacidade operacional, mas também da circunstância de a realidade ser mutável e se alterar ao longo do tempo, ampliando a dificuldade de que seja plenamente apreendida pela razão (PAULO GALA, "A teoria institucional de Douglass North". Revista de Economia Política, vol. 23, 2003, p. 94 e 99).

${ }^{117}$ Institutions, institutional change and economic performance. Ob. cit., p. 3.

${ }^{118}$ "New institutucionalism, economic and sociological". Center for the Study of Economic and Society". Disponível em: http://economyandsociety.org/publications/wp4_nee_03.pdf. Último acesso em: 20.10.2007, p. 23. Embora o conceito de VICTOR NEE tenha sido cunhado depois de dirigir crítica ao conceito de NORTH, não se vê incompatibilidade ontológica entre eles. Diversamente, entende-se como possível verificar uma relação de complementaridade. É certo que o conceito de V. NEE põe em foco característica relevante - o papel dos atores sociais - e permite que se percebam as instituições como resultado de interações sociais (algo que não é abordado e nem cogitado por NORTH). Porém, os traços fundamentais (presença de elementos formais e informais e a governança que exerce sobre a atuação dos agentes) parecem presentes nos dois conceitos.

${ }^{119}$ Quanto a isso, destaque-se o estudo de PAul J. DiMAggio e WALTER W. Powell ("The iron cage revisited: institutional isomorphism and collective rationality in organizational fields". American Sociological Review. vol. 48 (2), 1983, p. 147-160). Segundo eles, as organizações estariam submetidas a um processo de isomorfismo, cujo delineamento tenderia a homogeneização. Isso pode derivar de pressões exercidas por outras organizações (isomorfismo coercitivo), da imitação de soluções adotadas por outra organização atuante no mesmo setor (processo de mimetização) ou da linearidade na formação e nas relações dos profissionais que as compõem (pressões normativas). Note-se que Di MAGGIO E POWELL afirmam, de modo incisivo, que esse processo de isomorfismo pode ocorrer sem que haja qualquer evidência de que se está a ampliar a eficiência ("The iron cage revisited: institutional isomorphism and collective rationality in organizational fields". Ob. cit., especialmente p. 147 e p. 153). Em outras palavras: instala-se certa homogeneidade entre empresas do mesmo setor sem que, necessariamente, o modelo aplicado seja o mais eficiente para as organizações que o adotam.
} 
se desconsiderar que o agente responsável pela tomada de decisão está inserido em um meio social (e que, portanto, não age de modo atomizado).

Esse aspecto da questão é apreendido com bastante precisão pela Sociologia Econômica, desenvolvida especialmente por MARK GRANOVETTER. Segundo RICHARD SwEDBERG, uma das grandes contribuições de GRANOvETTER foi deixar de focar a eventual irrealidade do conceito de racionalidade adotado pelos economistas para passar a dar atenção ao fato de que os economistas não incorporam as estruturas sociais em suas análises. $^{120}$

De acordo com GRANOVETter, os indivíduos não se comportam e nem decidem como se fossem átomos, desconectados do contexto social. Ao contrário, as ações intencionais são enraizadas (embedded) em sistemas concretos e dinâmicos de relações sociais. ${ }^{121}$ Assim, as estruturas sociais (relações e redes sociais) ocupam um papel central na tomada de decisões e não podem ser desconsideradas na análise do processo decisório. ${ }^{122}$ Dessa forma, uma análise completa do modo de atuação do agente exige que sejam consideradas as relações sociais mantidas pelo indivíduo e as redes sociais em que ele está inserido. Afinal, "economic actions are never exclusively inspired by economic interests - as soon as the actor starts to interact with other actors, other interests also begin to intervene, namely social interests." 123 Essa necessidade de se considerar a inserção social no exame do processo de decisão dos agentes - e o impacto que exercem sobre o processo decisório - torna o problema da captura um fenômeno contingente (que pode ou

\footnotetext{
120 "New Economic Sociology: What has been accomplished, What is ahead?" Acta Sociologica. vol. 40(2), 1997, p. 162. Para comprovar tal assertiva, SWEDBERG cita primeira versão (não-publicada) do artigo seminal de GRANOVETTER, oficialmente publicado em 1985 ("Economic action and social structure. The problem of Embeddedness"), segundo a qual "Critics who have attempted to reform the foundations of economics have mainly been economists themselves. Their attack has typically been on the usual conception of rational action. It is my argument here that there is another fundamental feature of neoclassical economic theory that economic actors make decisions in isolation from one another - independent of their social connections: what I will call the assumption of 'atomized' decision-making." ("New Economic Sociology: What has been accomplished, What is ahead?" Acta Sociologica. vol. 40(2), 1997, 162).

121 MARK GRANOVETTER. "Economic action and social structure. The problem of Embeddedness". The American Journal of Sociology. vol. 91 (3), 1985, p. 487.

${ }^{122}$ Muitas vezes, ao se levar em conta essa inserção social, condutas aparentemente irracionais passam a ser explicadas por meio de padrões de racionalidade. Ou, nas palavras de GRANOVETTER, "I suggest, in contrast, that while the assumption of rational action must always be problematic, it is a good working hypothesis that should not easily be abandoned. What looks to the analyst like nonrational behavior may be quite sensible when situational constraints, especially those of embeddedness, are fully appreciated" ("Economic action and social structure. The problem of Embeddedness". Ob. cit., p. 506).

123 Richard Swedberg. Principles of economic sociology. Princeton and Oxford: Princeton University Press, 2003, p. 37.
} 
não ocorrer). ${ }^{124}$

\subsubsection{Conclusão parcial: exame das duas vertentes teóricas para a explicação da captura}

Ao longo deste capítulo, utilizou-se o termo "captura" para designar tanto o fenômeno detectado pela teoria econômica da regulação quanto aquele referido pela teoria do "ciclo de vida das agências reguladoras". Ainda que se tenha optado pelo uso amplo da expressão "captura", fato é que as duas teorias antes expostas fazem referência a fenômenos que podem ser diferenciados em alguns aspectos.

Sob o ângulo da teoria econômica, tem-se um regulador que, em termos genéricos, tende à captura. A regulação é fruto de diversas coalizões de interesses, que vão desde o legislador (que tutela os seus próprios interesses na busca de votos e dinheiro), passam pelos membros diretivos das agências reguladoras (que, por um lado, não pretendem se indispor com o legislador para manter intacto o seu espaço de atuação e que, por outro, não pretendem se contrapor à indústria regulada, por ver nela uma oportunidade para futura colocação profissional) e chegam aos grupos de interesses (especialmente, os grupos dos regulados), que têm condições de oferecer o que legisladores e reguladores pretendem. Estabelece-se um mercado político, em que a regulação é fruto do encontro da oferta e da demanda. Assim como os agentes econômicos, os agentes políticos empreendem, isto é, atuam pró-ativamente na busca da maximização dos seus próprios interesses.

Na teoria do "ciclo de vida das agências reguladoras", a captura não parece derivar dessa busca incondicionada pela maximização. Admite-se que o regulador pode, de

\footnotetext{
${ }^{124}$ Nesse passo, deve-se mencionar o trabalho de NEIL FLIGSTEIN, para quem as regras tendem a refletir os interesses do grupo que exerce dominação (incumbentes) em determinada sociedade. (The architecture of markets: an economic sociology of twenty-first-century capitalist societies. Princeton and Oxford: Princeton University Press, 2001, p. 16). A partir dessa ideia, FLIGSTEIN cunha tipos-ideais de sociedades e destaca a captura como expressão da intervenção no domínio econômico do tipo-ideal de sociedade dominada por grupos de capitalistas. Porém, além de se estar tratando de um tipo-ideal (que, em sua pureza, não se encontra na realidade) e de existirem outros tantos tipos-ideais de sociedade que não têm a captura como expressão da intervenção no domínio econômico, a dominação dos grupos e a formação de coalizões derivam de processos históricos e, portanto, os grupos dominantes se sucedem ao longo do tempo. (The architecture of markets: an economic sociology of twenty-first-century capitalist societies. Ob. cit., p. 16). Assim, e se a ocorrência de captura pode ser plausível em uma sociedade específica da atualidade, pode deixar de o ser em um futuro próximo. Basta que haja uma crise e que se forme uma nova coalizão política, que privilegie grupo de interesse diverso dos capitalistas (The architecture of markets: an economic sociology of twenty-first-century capitalist societies. Ob. cit., p. 56).
} 
início, visar à tutela do interesse público. Porém, ao longo do tempo, esse objetivo "desgasta-se". A agência, para adquirir segurança e estabilidade, acaba por se aproximar dos grupos de regulados e, ao fim, acaba por se tornar deles dependente. Diversamente do que se dá na explicação econômica, a captura resulta da apatia e da passividade da agência, que a impedem de se contrapor aos interesses dos regulados quando isso se faz necessário para o adequado exercício da regulação.

Em suma: enquanto a teoria econômica noticia um fenômeno que decorre da conduta ativa dos agentes envolvidos na regulação (o que inclui a atuação dos próprios membros da agência reguladora), a teoria do ciclo de vida indica que a ocorrência da captura decorre, justamente, da passividade da agência.

Se as duas teorias guardam essas diferenças, por que, então, se entendeu possível albergar sob a mesma expressão ("captura") os fenômenos por elas identificados? Se é certo que tal escolha encontra respaldo em doutrina específica, ${ }^{125}$ é igualmente correto que tal referência não é suficiente para sustentar a opção. Entendeu-se possível a reunião porque, embora as duas teorias trilhem caminhos diversos, acabam por identificar um mesmo problema: o comprometimento do regulador com o interesse privado (especialmente o interesse regulado) em detrimento do interesse público. Seja qual for o objetivo (maximização individual ou busca de segurança e estabilidade para a burocracia), seja qual for o modo de atuação (pró-ativa ou passiva), há o comprometimento daquilo que se espera do regulador (tutela do interesse público) em troca de algo (segurança, estabilidade ou benefícios pessoais atuais ou futuros).

O núcleo das duas explicações para captura parece ser, então, o comprometimento do interesse público em benefício do interesse privado. Diante disso, o presente trabalho não poderia deixar de examinar essa contraposição, o que é feito no tópico a seguir.

\footnotetext{
${ }^{125}$ Nesse sentido, MiChAEL E. LEVINE e JENNIFER L. FORRENCE ("Regulatory capture, public interest, and the Public Agenda: toward a synthesis". Ob. cit., p. 169). Porém, esses AUTORES reconhecem que, em termos estritamente históricos, o termo captura está conectado à idéia da "teoria do ciclo de vida", isto é, da noção segundo a qual a regulação pode, na origem, estar pautada no interesse público e, paulatinamente, ser dominada por interesses especiais. Adepta dessa diferenciação, reservando o termo "captura" somente para teoria do ciclo de vida das agências reguladoras, pode-se mencionar a obra de MARIA ROSARIA FERRARESE (Diritto e mercato: il caso degli Stati Uniti. Ob. cit., p. 359).
} 


\subsection{A característica central das explicações para a ocorrência da captura: o comprometimento do interesse público em benefício do interesse privado}

Como se percebe das teorias que identificaram o problema da captura, o problema por elas detectado tem como núcleo central o comprometimento do interesse público em detrimento do interesse privado. As questões que se põem são de duas ordens: (i) Quando o regulador tem espaço para gerar esse comprometimento? (ii) O que é, afinal, o interesse público comprometido?

\subsubsection{O espaço dado para a atuação do regulador}

No que concerne ao espaço em que o interesse público pode ser comprometido, remonta-se à diferença tradicional entre atos administrativos vinculados e atos administrativos discricionários. Às agências reguladoras são outorgadas competências das mais diferentes ordens (normativas, administrativas e quase-judiciais). Essa outorga se dá por meio de lei, que fixa standards gerais que devem ser por elas observados. Assim, a agência reguladora acaba, em primeiro lugar, editando normas que concedem maior concretude aos standards fixados em lei, estabelecendo direitos e deveres no setor sob sua competência. Posteriormente, pratica atos administrativos de execução das normas outrora editadas, como também arbitra os eventuais conflitos que possam surgir no seu âmbito de atuação. Para que possa exercer tais atividades, a lei precisa lhe outorgar discricionariedade, a fim de que tenha possibilidade de escolha entre diferentes soluções para uma mesma questão. Seria nessa margem de discricionariedade que a agência reguladora passaria a tomar decisões que comprometeriam o interesse público.

A questão está em que a margem de discricionariedade concedida à agência reguladora é consideravelmente ampla. Alberga não só a possibilidade de escolha em face da solução de determinado caso concreto, mas envolve, também, a outorga de competências normativas. Nesse último aspecto, o espaço discricionário parece mais amplo. Ainda que deva cumprir os standards gerais colocados pela lei que outorga a competência, a agência é responsável pela própria edição das normas, isto é, ela dita as regras que deverão ser observadas pelos atores do setor de sua atuação.

Além do âmbito da discricionariedade, nas agências reguladoras pode haver um “espaço de frouxidão"(slack), expressão utilizada por MICHAEL E. LEVINE para indicar não só a presença de discricionariedade, mas a falha no acompanhamento (quiçá, controle) 
da utilização dessa discricionariedade, de molde a se possibilitar que a escolha do regulador seja exercida à margem de eventual escrutínio público. ${ }^{126} \mathrm{E}$ por que essa possibilidade parece se colocar em face das agências reguladoras independentes? Por razões que derivam da estrutura e da função por elas exercidas. A atividade desenvolvida pela agência envolve uma plêiade de competências que regula completamente um setor econômico específico. Ela mesma é responsável pela edição das normas, pelo seu cumprimento e pela adjudicação dos conflitos com base nas normas por si editadas. $\mathrm{O}$ exercício de tais competências normalmente envolve temas de alta complexidade, que geram a edição de um volume significativo de regras (muitas vezes, em curto espaço de tempo). Tudo isso se passa sem que incidam os tradicionais instrumentos administrativos de controle (tal como a tutela e os recursos hierárquicos impróprios) e sem que o cidadão médio possa levar a efeito eventual controle popular. A par da apatia que normalmente o acomete no acompanhamento da tomada das decisões coletivas ${ }^{127}$, observar o desenvolvimento das atividades regulatórias tende a ser mais árduo, especialmente diante da tecnicidade dos temas discutidos e da eventual dificuldade para se apreender as repercussões concretas das decisões técnicas que estão sendo tomadas. ${ }^{128}$

\subsubsection{As dificuldades de eventual identificação do interesse público}

$\mathrm{O}$ segundo questionamento, que decorre diretamente do primeiro, não permite resposta simples. É possível, afinal, identificar o que seja interesse público? Ao mesmo tempo em que se recusa a identificação entre interesse público e interesse estatal, não são raras as tentativas de conceituar o que vem a ser interesse público, seja tomando-o como soma dos interesses dos integrantes de uma comunidade (interesse geral) ou da maioria de seus integrantes ${ }^{129}$, seja ao segregar os interesses individuais que se detém na

\footnotetext{
126 "Regulatory Capture", In: NEWMAN, Peter (Ed.).The New Palgrave Dictionary of Economics and the law. vol.3, New York: Palgrave Macmillan, 2002, p. 268.

${ }^{127}$ Tal como afirma MAURIZIO VIROLI, em obra conjunta com NORBERTO BOBBIO: "Hoje o problema não é apenas a tendência do poder para esconder-se, mas também o fato de que os cidadãos não estão interessados em ver. Há uma apatia difusa, pouquíssimo interesse em acompanhar os acontecimentos políticos". (Direitos e deveres na República: os grandes temas da política e da cidadania. Trad. de Daniela Beccaccia Versiani, São Paulo: Campus, 2007, p. 112).

${ }^{128}$ A idéia de slack de MiCHAEL E. LEVINE está intimamente ligada à idéia da possibilidade de se exercer, de forma opaca (no sentido de não-transparente), as relações de poder no âmbito das agências reguladoras.

129 Tal como o faz HÉCTOR JORGE ESCOLA ao afirmar que "El interés público, de tal suerte, puede ser un querer valorativo general y total en una comunidad, pero no tiene necesariamente que serlo, bastando con que aparezca como la expresión de una mayoría, del que se tenga conciencia como tal" (El interes público como fundamento del derecho administrativo. Buenos Aires: Depalma, 1989, p. 239). Em última medida, há identificação entre o interesse público e os interesses da maioria. Sobre a questão e os problemas que decorrem da adoção da regra da maioria, confira-se CELSO FERNANDES CAMPILONGO, Direito e democracia. São Paulo: Max Limonad, 1997.
} 
esfera privada daqueles existentes na vida em sociedade (para afirmá-lo como "interesse resultante do conjunto de interesses que os indivíduos pessoalmente têm quando considerados em sua qualidade de membros da Sociedade e pelo simples fato de o serem ${ }^{130}$ ), seja, ainda, ao privilegiar um viés econômico, afirmando-se que "O interesse geral não é, portanto, o interesse da comunidade considerada como uma entidade distinta dos que a compõem e superior a eles; é muito mais simplesmente, um conjunto de necessidades humanas - aquelas a que o jogo das liberdades não provê de maneira adequada e cuja satisfação, todavia, condiciona a realização dos destinos individuais."

Porém, em nenhum dos casos, o conceito é dotado de autonomia ou de cunho aplicativo. Não é dotado de autonomia porque os conceitos pretendidos acabam por relacionar o interesse público com alguma espécie de interesse privado. Embora o façam na tentativa de diferenciar, os conceitos acabam por identificar o interesse público com uma parte do interesse privado. Depois, não seria aplicativo porque não é possível, a partir deles, saber com precisão quando se está (e quando não se está) diante de um interesse público. Isso é reconhecido por JEAN RIVERO ao consignar que "A delimitação do que entra no interesse geral varia com as épocas, as formas sociais, os dados psicológicos, as técnicas; mas se o conteúdo varia, o fim continua o mesmo: a acção administrativa tende à satisfação do interesse geral". ${ }^{132}$ Logo, sabe-se que a atuação da Administração Pública (e, por conseguinte, das agências reguladoras) deve ser a consecução do interesse público, mas a questão quanto ao seu conteúdo permanece em aberto.

Se é fato que essa dificuldade não é inédita - em meados do século XIX, IHERING, ao identificar a existência de interesses individuais, estatais e sociais reconhecia que, em temas estritamente privados, efetivamente tutelam-se interesses privados, mas, em um segundo nível, essa preocupação também traz consigo a tutela de interesses estatais e sociais, ${ }^{133}$ tornando difícil identificar com precisão os limites entre cada uma das

\footnotetext{
${ }^{130}$ Celso Antônio Bandeira de Mello, Curso de Direito Administrativo. $17^{\mathrm{a}}$ ed., São Paulo: Malheiros, 2004, p. 53.

${ }^{131}$ JEAN RIVERo. Direito Administrativo. Trad. de Rogério Ehrhardt Soares, Coimbra: Almedina, 1981, p. 15.

${ }^{132}$ Direito Administrativo. Ob. cit., p. 15.

${ }^{133} \mathrm{Na}$ exposição de JULIUS STONE acerca da doutrina de IHERING consigna-se que "Contracts and tort (delict) and quase-contracts and quase-delict, were in major part directed to private interests of property, or integrity of the physical person and honour. But part was also directed to the state's interest, and part, for instance, much of quasi-contract and quasi-delict, to the security of social interests" (The province and function of law: law as logic, justice and social control. $2^{\text {nd }}$ ed., Cambridge: Harvard University Press, 1950, p. 310). Quanto à diferenciação em interesses individuais, sociais e estatais, JULIUS STONE indica que essa é a segunda distinção feita por IHERING. Inicialmente, ele detecta cinco espécies de interesses: individuais, estatais, associativos, eclesiásticos e sociais. Esses cinco são reduzidos aos três a que se fez referência no corpo do
} 
categorias de interesses -, na sociedade contemporânea, ela se torna maior. A assunção de novas tarefas pelo Poder Público unida à tutela pública de interesses heterogêneos (que, por vezes, não podem ser reconduzidos à generalidade da comunidade) tornam ainda mais confusos os limites entre os interesses públicos e privados. ${ }^{134}$ Daí se concordar com TÉRCIO SAMPAIO FERRAZ JÚNIOR, para quem a idéia de "interesse público" é um lugar comum, "que, em tese e por princípio, não admite definição". ${ }^{135}$

Todas essas dificuldades tornam a identificação do problema da captura ainda mais complexa. Se a idéia de captura tem como centro a prevalência de interesse privado em face do interesse público, ela só faz sentido se for possível identificar, de alguma forma, o que é interesse público. Se isso não for passível de ser feito, ou o problema da captura é um pseudo-problema (se não se consegue diferenciar interesse público e interesse privado, problema não há) ou o núcleo da questão está em outro lugar. Como se tentará demonstrar a seguir, o problema da captura não é um pseudo-problema. Porém, efetivamente, o seu centro está em outro lugar.

O fato de não se poder indicar, a priori, o que é interesse público não significa que ele não possa ser identificado (mesmo que em concreto e de modo relacional). Quanto a essa possibilidade, alude-se à lição de TÉRCIO SAMPAIO FERRAZ JÚNIOR, para quem a "dicotomia interesse público-interesse privado" também é um lugar comum que, examinada caso a caso, permite definir espaços interpretativos e locais de intervenção da autoridade no âmbito particular. Assim, em face de temas concretos, é possível estabelecer uma linha limitadora entre interesse público e interesse privado e identificar os campos de atuação do Poder Público.

Depois, e ainda de acordo com TÉRCIO SAMPAIO FERRAZ JÚNIOR, “o que se observa é a passagem de um termo [interesse público] que tinha ou possivelmente teve uma função descritiva, isto é, interesse público descrevia um âmbito, em oposição a interesse privado, que descrevia um outro âmbito, para uma função eminentemente

trabalho. A mesma dificuldade se encontra nos estudos de ROSCOE POUND, que também enxerga essa possibilidade de identificação. Afirma que, em última análise, os interesses públicos podem ser reconduzidos a interesses sociais e esses a interesses individuais (mas o contrário não seria verdadeiro; interesses individuais e sociais só poderiam ser reconduzidos a interesses públicos em um aspecto reduzido: no aspecto político da vida individual e social). Confira-se Julius STONE, The province and function of law: law as logic, justice and social control. $2^{\text {nd }}$ ed., Cambridge: Harvard University Press, 1950, p. 491.

${ }_{134}$ A propósito, confira-se FloRIANo DE AZEVEDO MARQUES NETO ao fazer referência à doutrina de MASSimo SEVERo GiANNini (Regulação estatal e interesses públicos. São Paulo: Malheiros, 2002, p. 89-91).

${ }_{135}$ "Interesse Público". Texto disponível em: http://www.terciosampaioferrazjr.com.br/?q=/publicacoescientificas/34. Último acesso: 21.11.2008. 
prescritiva. E nessa função prescritiva, torna-se instrumento de intervenção do 'aplicador' nas relações sociais (...)"136 Assim, e na medida em que a expressão "interesse público", "usata al singolare, non corrisponde ad uma realtà diretamente ed univocamente definibile"137 e que na sociedade contemporânea a Administração Pública assume a tutela de um plexo de interesses diferentes (e, por vezes, contraditórios), a definição de interesse público acabará por ser ditada pelo aplicador do direito (na hipótese deste trabalho, pelo regulador). Há, portanto, uma ampliação da liberdade do regulador, a quem se acomete o dever de delimitar o interesse público e justificar a ação estatal.

Tal como afirma Floriano PeiXoto de Azevedo Marques Neto, “de corpo profissional, impessoal, técnico e objetivo, a burocracia do Estado torna-se, mais e mais, 'intérprete do interesse público'. Diante da indefinição ou da abertura conceitual da lei, passa o agente burocrático a ser o ente capacitado para, no caso concreto, definir unilateralmente onde reside o interesse público justificador de uma manifestação concreta do poder político."138

Portanto, mais relevante que o esforço para definir interesse público, é aquele destinado a tentar descrever e determinar critérios - intersubjetivamente controláveis - que devem ser aplicados quando da definição de interesse público pelo regulador. ${ }^{139}$ Nesse esforço, alguns critérios se apresentam de imediato.

\section{a) A chancela legal do regulador e o método de validação da norma regulatória}

O primeiro desses critérios relaciona-se com a noção que decorre do princípio da estrita legalidade: toda e qualquer atuação da Administração Pública deve contar com algum grau de previsão legal (isto é, precisa estar respaldada, de alguma forma, por ato emitido pelo Poder Legislativo). Portanto, a avaliação de conveniência e oportunidade conferida à Administração Pública e mesmo as prerrogativas que lhe são outorgadas têm amparo (mas também limite) normativo.

Relativamente ao poder normativo das agências reguladoras - lugar em que

\footnotetext{
136 "Interesse Público". Texto disponível em: http://www.terciosampaioferrazjr.com.br/?q=/publicacoescientificas/34. Último acesso: 21.11.2008.

137 AlESSANDro PIZZORUSSO, "Interesse pubblico e interessi pubblici". Revista Trimestrale di Diritto e Procedura Civile. Milano, ano XXVI, mar. 1972, p. 68.

${ }^{138}$ Regulação estatal e interesses públicos. São Paulo: Malheiros, 2002, p.94.

139 Humberto Ávila. "Repensando o 'princípio da supremacia do interesse público sobre o particular". Revista Diálogo Jurídico. Salvador, vol. I (7), outubro-2001, p. 18.
} 
se encontra o mais intenso nível de discricionariedade outorgado às agências -, tem-se que a lei-quadro de constituição da agência é, também, a lei que confere a (e define os limites da) competência normativa da agência reguladora. Às normas regulatórias, aplicar-se-á um critério de validação finalística, isto é, a norma regulatória terá de ser apta a atingir as finalidades que autorizaram a outorga da competência.

Quanto a isso, faz-se referência à construção de TÉRCIO SAMPAIO FERRAZ JÚNIOR ao indicar que as reações possíveis do ouvinte [aqui, sujeito a quem é endereçada a norma] em relação a uma definição do orador [aqui, orador normativo] são três: confirmar, rejeitar ou desconfirmar. Pela confirmação, o ouvinte aceita a definição ("compreende e concorda"); pela rejeição, o ouvinte nega a definição ("compreende e discorda"); e pela desconfirmação, o ouvinte desqualifica a definição ("não compreende ou ignora"). ${ }^{140}$ Nos dois primeiros casos, o destinatário da norma reconhece a autoridade do emissor (mesmo na hipótese de descumprimento, o sujeito descumpre, mas assume os riscos decorrentes de tal conduta. Reconhece, portanto, a autoridade da norma). No último, a autoridade é ignorada. Age-se como se ela não existisse.

\section{Ainda de acordo com TÉRCIO SAMPAIO FERRAZ JÚNIOR,}

uma norma é válida na medida em que seu editor consegue manter-se como autoridade perante o sujeito, i.é, na medida em que se imuniza contra eventuais desconfirmações. Juridicamente, esta imunização se obtém através de outra norma que por sua vez a obtém de outra, significando isto que a validade é uma relação de imunização dentro de um ordenamento. A imunização, entretanto, é obtida através de duas diferentes técnicas de validação que denominaremos técnica finalista e técnica condicional. ${ }^{141}$

Assim, a lei-quadro de constituição da agência reguladora independente imuniza a norma regulatória. Para tanto, tem as duas técnicas ao seu dispor. Ou fixa as condições de edição da norma (estabelecendo, por exemplo, a competência, os aspectos da hipótese de incidência etc.) e deixa em aberto os fins que devem ser atingidos; ou consigna os fins que devem ser atingidos, cabendo ao emissor da norma inferior a escolha dos meios para que sejam atingidos. No primeiro caso, há uma desvinculação dos meios e dos fins. $\mathrm{O}$ emissor da norma inferior precisa se preocupar somente com o atendimento das condições, mas não com as consequências da norma. Como os meios já estão pré-fixados, o editor da norma que a atende se exime das críticas quanto aos fins. Na segunda situação, não se consegue desvincular os meios dos fins. Com a prefixação dos fins, o emissor da norma é

${ }^{140}$ Teoria da Norma Jurídica, $4^{\text {a }}$ ed., Rio de Janeiro: Forense, 2006, p. 57.

141 “A relação meio/fim na teoria geral do Direito Administrativo". Revista de Direito Público. São Paulo, vol. 61, p. 30. Ver, do mesmo autor, Teoria da Norma Jurídica, Ob. cit., p. 109 e ss. 
responsável pela escolha de meios adequados para que os fins sejam atingidos. Para controlar a validade da norma, não bastará verificar, tão-somente, se a autoridade detinha competência para a edição da norma, mas se deve verificar, casuisticamente, se a adequação meios/fins foi obtida. ${ }^{142}$

Quando a lei-quadro opta por conceder discricionariedade à agência, estabelece genericamente competências e fixa os fins que devem ser atendidos pelo exercício da regulação. Portanto, "não lhe bastam (...) os requisitos da validade condicional (ou requisitos formais de vigência) (...), pois a mera utilização dos meios não significa que deles decorram, necessariamente, os fins colimados."143 A verificação da validade se dará de modo casuístico, e "nos obriga a pensar em probabilidade e chances, escalas móveis, proporções de valores e oportunidades condicionadas pelo tempo." ${ }^{144}$ Nessa medida, e de modo até mesmo paradoxal, a fixação de finalidades pela norma de atribuição de competência à agência reguladora - por mais genérica que seja tal atribuição - acaba por revelar critério que permite o controle do exercício de suas competências.

\section{b) O necessário “desinteresse” do responsável pela edição da regulação}

Em segundo lugar - e o que é mais relevante para este trabalho -, se se admite que o interesse público é um conceito aberto, a ser fixado pelo aplicador do direito, o desinteresse pessoal é a conditio sine qua non para que essa definição possa ser levada a efeito. Como consigna Josef ISENSEE, autor referido por HuMBERTO ÁviLA em estudo sobre o tema, "O bem público e o bem particular determinam fins, enquanto o desinteresse pessoal e o interesse pessoal marcam caminhos. No primeiro caso trata-se de objeto; no segundo, de procedimento; aqui de programa, lá de realização."145 Assim, "A constatação de que os funcionários não representam interesses outros além do público não resulta do interesse público propriamente dito (definido, aliás, pela finalidade), mas do desinteresse,

\footnotetext{
142 “A relação meio/fim na teoria geral do Direito Administrativo”. Ob. cit., p. 30-31.

143 “A relação meio/fim na teoria geral do Direito Administrativo". Ob. cit., p. 33.

144 "A relação meio/fim na teoria geral do Direito Administrativo". Ob. cit., p. 33. TÉRCIO SAMPAIO FERRAZ JÚNIOR retoma a construção não só para indicar que a discricionariedade da atuação da agência reguladora está submetida ao critério de validação finalística, mas também para submetê-la a deveres que derivam do princípio da eficiência ("O poder normativo das agências reguladoras à luz do princípio da eficiência". In:ARAGÃO, Alexandre Santos de (Coord.). O poder normativo das agências reguladoras. Rio de Janeiro: Forense, 2006, p. 271-297.

145 Humberto Ávila. "Repensando o 'princípio da supremacia do interesse público sobre o particular". Revista Diálogo Jurídico. Salvador, vol. I (7), outubro-2001, p. 20. O texto de JOSEF ISENSSE referido por Humberto Ávila é “Gemeinwohl und Staatsaufgaben im Verfassungsstaat”, in: HStR, §57, Rn. 62.
} 
por sua vez reconduzido à função pública e ao princípio republicano”. ${ }^{146}$

Nesse ponto, torna-se claro que a captura não é um pseudo-problema. Quando se fala em comprometimento do interesse público em benefício do interesse privado está-se a dizer, em verdade, que o regulador não age de modo desinteressado. Seja na tentativa de maximizar os ganhos que podem decorrer da atuação alinhada a interesses privados (explicação econômica da captura), seja na busca de um espaço de segurança e conforto no exercício de suas atividades (explicação do ciclo de vida das agências reguladoras), o regulador deixa de atuar de modo desinteressado e passa a tutelar interesses específicos que, ao fim, poderão conduzir à captura. Em outras palavras: se a definição concreta e a tutela do interesse público dependem da atuação desinteressada do regulador e a captura identifica que o regulador atua (e tutela) interesses específicos, torna-se claro que a captura é um problema efetivo.

Por outro lado, essa identificação também torna presente que o núcleo duro do problema da captura está em outro lugar. A questão central do problema está em momento anterior: no comprometimento do "desinteresse" que deve pautar a atuação do regulador. O comprometimento do interesse público em favor do interesse privado é, em verdade, a consequência que decorre do fato de o regulador não agir de modo desinteressado. O tema é tratado com mais vagar no tópico seguinte.

\subsection{A autonomia do regulador em face dos interesses em jogo}

O "desinteresse" que deve pautar a atuação do regulador é mais bem compreendido como autonomia do responsável pelo exercício da regulação em relação aos interesses em jogo. Em princípio, autonomia pode ser tida em dois sentidos. O primeiro é o da completa desvinculação dos objetivos do regulador relativamente às forças que integram a sociedade; autonomia corresponderia, então, ao completo insulamento do responsável pelo exercício da regulação. O segundo relaciona-se com a habilidade de se formular, de modo autônomo, objetivos coletivos (ainda que não se esteja diante do completo isolamento do regulador). ${ }^{147}$

Em termos estritamente lógicos, faz sentido defender o primeiro dos

\footnotetext{
${ }^{146}$ HUMBerto Ávila. "Repensando o "princípio da supremacia do interesse público sobre o particular". Revista Diálogo Jurídico. Salvador, vol. I (7), outubro-2001, p. 20.

${ }^{147}$ Peter Evans, Embedded Autonomy: States \& Industrial Transformation. Princeton: Princeton University Press, 1995, p. 44.
} 
sentidos enunciados, isto é, a autonomia como equivalente a insulamento, propugnando o afastamento completo do regulador (seja da realidade social, seja do embate dos interesses que aí se colocam). Por meio desse completo afastamento, o regulador estaria protegido dos riscos de se relacionar com os interesses em jogo (sejam eles quais forem), estando mais apto a adotar condutas puramente desinteressadas. Todavia, há dois motivos (extremamente relevantes) que impedem que se adote esse primeiro sentido.

Por um lado, a mesma crítica que acima se fez quanto à impossibilidade de que o indivíduo adote condutas completamente atomizadas também é aqui aplicável. ${ }^{148} \mathrm{Se}$ é verdade que o agente econômico não tem condições de agir de forma absolutamente desvinculada da realidade social em que está inserido, o mesmo se deve dizer em relação ao regulador. Ele também não detém condições de se afastar por completo da realidade social que o circunda. Tal como afirma PETER EvAns, "The idea that states operate most effectively when their connections to society are minimized is no more plausible than the idea that markets operate in isolation from other social ties. Just as in reality markets work only if they are 'embedded' in other forms of social relations, it seems likely that states must be 'embedded' in order to be effective". 149

Por outro, a regulação visa à tutela do interesse público que, conforme já exposto, é construído e identificado quando do próprio exercício da regulação. Para que possa levar a efeito essa definição, é adequado que o regulador tome em conta a realidade social e os interesses que a permeiam. Primeiro porque se nega a natureza de "direito natural" às normas regulatórias. Não são elas produtos exclusivos da natureza racional do homem que se impõem por tal característica. ${ }^{150}$ Depois, porque mesmo tendo as normas regulatórias caráter de normas positivas (normas editadas por autoridade com competência para tanto e que, em ultima ratio, envolvem atos de vontade), não se deve olvidar que elas não devem prever o impossível e precisam deter um mínimo de eficácia para que sejam tomadas como válidas. ${ }^{151}$ E essas condições podem ser mais facilmente preenchidas com a

\footnotetext{
${ }^{148}$ Confira-se item 2.1.2, "c", supra.

${ }^{149}$ Embedded Autonomy: States \& Industrial Transformation. Ob. cit., p. 41.

${ }^{150}$ Sobre as características do direito natural e a sua contraposição em relação ao direito positivo, confira-se Norberto Bobbio, O positivismo jurídico: lições de filosofia do direito. Trad. de Márcio Pugliesi, Edson Bini e Carlos E. Rodrigues. São Paulo: Ícone, 1995, p. 20-21.

${ }^{151}$ Hans Kelsen, Teoria Geral das Normas. Trad. de José Florentino Duarte. Porto Alegre: Sérgio Antônio Fabris Editor, 1986, p. 179. A eficácia é condição de validade da norma jurídica, isto é, "eficácia é condição no sentido de que uma ordem jurídica como um todo e uma norma jurídica singular já não são consideradas como válidas quando cessam de ser eficazes" (HANs KelsEn, Teoria Pura do Direito. Trad. de João Baptista Machado, $7^{\text {a }}$ ed., São Paulo: Martins Fontes, 2006, p. 236). Quando a norma prevê uma conduta impossível,
} 
consideração da realidade social que se pretende regular. ${ }^{152}$

Diante dessas considerações, parece adequado adotar o segundo sentido de autonomia, que envolve a possibilidade de se buscar fins coletivos de modo desvinculado dos interesses individuais do regulador. Isso, contudo, não significa que o regulador não esteja inserido no meio social e não sofra o influxo dos embates de interesse que ali se colocam e das próprias características pessoais do responsável pela tomada de decisão. Afinal, como afirma KARL LARENZ,

Cada homem está marcado em seu modo de entender as coisas, seja por sua origem, por seu envolvimento vital, pela educação cultural recebida, por suas experiências vitais e profissionais, e muitos outros fatores mais. A 'independência de pensamento' não é congênita para ninguém e tampouco se adquire com instrução, senão que exige trabalho solitário do homem ao longo de sua vida. 153

Ele, por certo, sofre as influências dos interesses em jogo e de sua própria formação pessoal, mas, apesar disso, age autonomamente, sem compromisso prévio com qualquer grupo de interesse específico. A autonomia nesse segundo sentido aproxima-se da idéia de imparcialidade que se exige dos membros do Poder Judiciário, mas que também se aplica à Administração Pública. ${ }^{154}$

Tal como afirma Maria Teresa De Melo Ribeiro, a imparcialidade que se exige da Administração Pública pode ser explicada a contrario sensu, invocando-se a ideia de parcialidade. Parcialidade pode ser compreendida de duas formas: como parte de uma disputa (e que, portanto, atua com subjetividade na busca de interesses egoísticos) e como parte de um todo. A noção de imparcialidade depende dessas duas nuances. Por um lado, é o exato contraposto da idéia de subjetividade e tutela de interesses egoísticos, revelando-se

tolhe-se, de pronto, a possibilidade de que a norma venha a ser eficaz. Sabe-se, de antemão, que a condição de validade da norma (eficácia) não tem como se perfazer. Logo, a norma não será dotada de validade (HANS KELSEN, Teoria Geral das Normas. Ob. cit., p. 179).

${ }^{152}$ Especialmente quando se faz referência à eficácia, a sentença ora enunciada deve ser lida nos estritos termos em que foi colocada: voltar os olhos para a realidade social pode facilitar a edição de norma dotada de eficácia. Contudo, a ausência de tal preocupação (a edição da norma sem tal tipo de consideração) não tem o condão de invalidar a norma. Como alerta KELSEN na passagem já mencionada, a eficácia é condição de validade (e não é fundamento da validade). Por isso, o fato de se ter uma norma eficaz tem-se o preenchimento de uma condição para que se tenha uma norma válida; porém, o fato de se estar diante de tal condição não causa, por si, a validade da norma.

${ }^{153}$ Derecho Justo: fundamentos de ética jurídica. Trad. de Luis Díez-Picazo. Madrid: Civitas, 1985, p. 183. No âmbito estrito do Direito Administrativo, TÉRCIO SAMPAIO FERRAZ JÚNIOR destaca que a atribuição de competências discricionárias envolve edição de normas "cuja validade jamais se liberta do juízo de valor do seu emissor", sendo impossível uma "impessoalização neutra" ("A relação meio/fim na teoria geral do Direito Administrativo". Ob. cit., p. 33).

${ }^{154}$ UMBERTO ALLEGRETTI estende o dever de imparcialidade a todas as funções estatais, de molde a abranger, também, a função legislativa (L 'Imparzialità Amministrativa. Pádua: CEDAM, 1965, p. 55-57). 
como conduta objetiva, desvinculada dos interesses em jogo (portanto, neutra, isenta e independente). Por outro, a sua plenitude se revela quando se tem atenção ao todo (e não só à parte dele). A imparcialidade exige, portanto, que se "tenha em atenção a totalidade dos interesses afectados pela própria acção". ${ }^{155}$

Essas duas vertentes dão origem a duas teses que visam explicar o alcance do dever de imparcialidade. A primeira, denominada tese negativa ou subjetiva, toma a imparcialidade como mecanismo para manter a Administração Pública imune aos interesses que se colocam no exercício da atividade administrativa (quer interesses privados, quer interesses pessoais do responsável pela atividade administrativa, quer interesses partidários ou, mesmo, de Governo). Envolve uma vertente negativa porque impõe proibições para a Administração Pública, com vistas a garantir que ela atue de forma objetiva (com base em critérios jurídico-racionais), isenta (sem o busca de interesses próprios dos funcionários responsáveis pela atividade administrativa), neutra (em posição de eqüidistância dos interesses em jogo) e independente (indiferente às pressões exercidas pelos grupos interessados no desempenho da atividade administrativa). A segunda é denominada tese positiva ou objetiva, pois, de modo mais abrangente que a primeira, defende que a imparcialidade impõe à Administração o dever de ponderar de forma adequada os interesses em jogo antes da tomada da decisão. ${ }^{156}$

À primeira das vertentes teóricas aplicam-se as críticas que se fez à primeira aproximação de autonomia. Faticamente, não parece haver condições para a Administração manter-se completamente alheia aos interesses sociais sobre os quais, muitas vezes, terá de decidir. Aliás, e tão como anteriormente exposto, há dúvidas, até mesmo, de que isso fosse recomendável. Todavia, isso não significa que as contribuições de tal vertente sejam irrelevantes. Se à referida vertente teórica for atribuída outra finalidade (não a de afastar por completo a Administração dos interesses em jogo, mas a de impedir que a Administração Pública esteja comprometida de antemão com alguma espécie dos interesses que estão em jogo), seus aportes podem se revelar extremamente úteis, especialmente quando unidas à segunda das vertentes teóricas. As proibições que decorrem do dever de impessoalidade e os objetivos por ela visados passam a servir de garantia para que a atuação administrativa de que trata a segunda vertente teórica (ponderação de todos os interesses em jogo em determinada questão) possa ocorrer de forma efetiva e sem o

${ }^{155}$ O princípio da imparcialidade da Administração Pública. Coimbra: Almedina, 1996, p. 17.

${ }^{156}$ O princípio da imparcialidade da Administração Pública. Ob. cit., p. 153-155. 
comprometimento prévio da Administração.

Note-se que o problema da captura ocorrerá justamente no espaço em que aquele conjunto de garantias não funciona. A atuação da Administração será favorável e, até mesmo dependente, de alguns dos interesses em jogo, o que coloca em causa a própria ponderação e respectiva avaliação a ser levada a efeito pela atividade administrativa. $\mathrm{O}$ detalhe está em que as características da atividade regulatória tornam mais intensa a possibilidade de que esse comprometimento ocorra.

Relativamente à atividade administrativa tradicional, MARIA TERESA DE MELO RIBEIRO afirma que "Os interesses perseguidos pela Administração são interesses públicos, predeterminados pelo legislador, interesses que, por natureza, são objectivos, pelo que objectiva deve ser a conduta que os prossegue e objectivos devem ser os instrumentos utilizados para a sua prossecução". ${ }^{157}$ Ocorre que essa predeterminação pelo legislador nem sempre ocorre nas leis de criação das agências reguladoras.

Tal como acima minudenciado, a atividade da agência reguladora envolve a conjugação de competências normativas, executivas e quase-judiciais, fixadas em uma leiquadro. Menos que normas de condutas, as leis de criação das agências envolvem a atribuição de uma plêiade de competências. Há, aí, uma "não pequena área de discricionariedade para os órgãos que recebem não apenas a delegação de poderes normativos como ainda as atribuições de controle, orientação e fiscalização da conduta dos particulares". ${ }^{158}$ Nesse espaço não só se deve atender ao interesse público prévia e objetivamente descrito em lei (tal como ocorre na atuação administrativa tradicional), mas, especialmente, é nele que se constrói a noção concreta de interesse público para determinados temas. Portanto, aqui, a objetividade - tida como expressão do dever de imparcialidade da Administração Pública - fica mitigada pela eventual ausência de prédeterminação legal do interesse público a ser perseguido, tornando mais plausível o comprometimento da imparcialidade.

Não fosse isso, há um dado ainda mais relevante que precisa ser considerado. As agências reguladoras atuam em setores econômicos específicos, tutelando as atividades com eles relacionadas. Normalmente, as decisões por si tomadas irão impactar (seja positiva, seja negativamente) sobre os agentes econômicos vinculados ao

${ }^{157}$ O princípio da imparcialidade da Administração Pública. Ob. cit., p. 162 (original sem destaque).

${ }^{158}$ FÁBIO NUSDEO. "O direito econômico e os grupos de pressão". Ob. cit., p. 132. 
setor. Esses agentes, portanto, têm todo o interesse em se organizar, de molde a poderem exercer pressão sobre o responsável pela regulação. Para expor essa ideia com maior clareza, recorre-se à construção teórica de MARCUR OLSON, que diferencia grupos grandes e pequenos (assim definidos pelo número de indivíduos ou organizações que os integram), afirmando que:

The most important single point about small groups in the present context, however, is that they
may very well be able to provide themselves with a collective good simply because of the
attraction of the collective good to the individual members. In this, small groups differ from larger
ones. The larger a group is, the farther it will fall short of obtaining an optimal supply of any
collective good, and the less likely that it will act to obtain even a minimal amount of such a good.
In short, the larger the group, the less it will further its common interests. 159

Depois de ressaltar a relevância da diferença do tamanho dos grupos, OLSON identifica realidades diversas.

Primeiro, os grupos pequenos (ou de dimensões oligopolísticas) podem ser divididos em grupos privilegiados e grupos intermediários. Os grupos privilegiados envolvem aqueles em que pelo menos um dos seus membros tem um significativo interesse na obtenção do benefício coletivo a ponto de se dispor a arcar sozinho com os custos de sua obtenção. Nesses casos, o benefício coletivo será obtido independente de organização e acordo entre os integrantes do grupo. Os grupos intermediários envolvem as situações em que nenhum dos membros obtém, sozinho, vantagem tão grande que compense custear isoladamente a obtenção do benefício. A obtenção de benefícios coletivos depende da coordenação ou da organização do grupo. Porém, o grupo é composto por um número restrito de integrantes de forma que, havendo o acordo, seus membros possam se controlar mutuamente. Cada um dos membros tem condições de verificar se o outro está (ou não) contribuindo com a obtenção do benefício coletivo. Quando os custos de organização forem inferiores às vantagens que podem ser obtidas por meio da atuação conjunta, os seus integrantes tendem a se organizar com vistas à obtenção do benefício. ${ }^{160}$

Por fim, haveria os grupos latentes (de dimensões equivalentes ao da competição atomizada no mercado). Nesses, os seus membros não têm incentivo para envidar esforços na obtenção do benefício coletivo, pois há intensa dificuldade em saber se os integrantes do grupo estão (ou não) contribuindo para a obtenção do benefício coletivo,

${ }^{159}$ The logic of collective action: public goods and the theory of groups. Cambridge: Harvard University Press, 1965, p. 36.

${ }^{160}$ The logic of collective action: public goods and the theory of groups. Cambridge: Harvard University Press, 1965, p. 49-50 e p. 46. 
assim como fica mitigada a possibilidade de reação dos demais membros quando se identifica determinado desvio (isto é, a conduta desviante não gera efeitos significativos sobre os demais membros do grupo que não têm razão para agir). Relativamente a esses grupos, o normal é que não consigam se organizar com vistas à realização de benefícios coletivos. E isso por três motivos. Primeiro, quanto maior o grupo, menor e menos adequada tende a ser recompensa para aqueles que envidam esforços na obtenção do benefício coletivo. Depois, quanto maior o grupo, menor tende a ser a fração de ganho de cada um dos indivíduos que o integram (há menor probabilidade de que se ganhe o suficiente para empreender conduta que gere o benefício coletivo). Por fim, quanto maior o grupo, maiores são os custos de organização. Em resumo: há uma conjugação entre parcela reduzida de benefícios que podem ser apreendidos individualmente e custos altos que precisam ser suportados, o que tornaria rara a organização de grupos grandes com vistas à obtenção de benefícios coletivos. ${ }^{161}$

Ao se considerar que do exercício da regulação - especialmente na sua vertente de poder normativo - pode resultar regras favoráveis ou contrárias aos agentes econômicos vinculados a dado setor (muitas delas aptas a configurar "benefícios coletivos" para esses mesmos agentes econômicos) e tomando-se o referencial teórico de MARCUR OLSON, torna-se claro que tais agentes têm interesse em se organizar em grupo com vistas a exercer pressão sobre o regulador, de molde a tentar obter a regulação que lhes seja mais favorável. $^{162}$

O grupo formado pelos agentes econômicos afetados pela regulação (seja na

\footnotetext{
${ }^{161}$ The logic of collective action: public goods and the theory of groups. Ob. cit., p. 50-51 e p. 48. A construção de MARCUR OLSON é especialmente relevante quanto aos grandes grupos e à dificuldade de que envidem esforços na obtenção de um benefício coletivo. Em que pese essa dificuldade dos grandes grupos já ter sido antes identificada por DAVID HUME - conforme relatada o próprio OLSON (The logic of collective action: public goods and the theory of groups. Ob. cit, p. 50-51 e p. 33, nota 53), em Tratado da Natureza Humana, HuME destaca que não há qualidade da natureza humana que cause mais erros do que aquela que nos leva a preferir algo presente e imediato em relação a algo distante e remoto e aquela que nos faz preferir as coisas mais pela sua situação do que pelo seu valor intrínseco. Para exemplificar, HuME destaca que é relativamente fácil dois vizinhos acordarem sobre a drenagem de dado terreno porque ambos conseguem perceber as intenções um do outro; porém, um acordo para o mesmo fim entre mil pessoas seria extremamente complexo ou impossível, pois as pessoas tenderiam a encontrar bons pretextos para se livrar dos problemas e gastos derivados do projeto e tentar imputá-los às demais pessoas -, fato é que as teorias ortodoxas dos grupos de interesse entendem que a atuação dos grupos menores é mitigada pela potencial atuação dos grandes grupos, que "would arise and organize to do battle with the special intersts if the special interests got far out of line" (The logic of collective action: public goods and the theory of groups. Ob. cit., p. 124). Nessa passagem, MARCUR Olson está a se referir aos estudos de DAVID B. TRUMAN, em The Governmental Process (New York, Alfred A. Knopf, 1958).

162 Isso não significa que, na realidade, não se encontrem grandes grupos organizados (a respeito, ver as lições de NEIL KOMESAR mencionadas na nota 167, infra). Só se chama a atenção para o fato de que há a tendência de que grupos menores se organizem com maior facilidade.
} 
qualidade de regulado, seja na qualidade de "grande consumidor") tende a contar com um número restrito de potenciais integrantes. Envolvem grupos de dimensões oligopolísticas que, conforme o caso, podem se constituir como grupos privilegiados (em que a vantagem derivada da obtenção da decisão pode ser tão significativa a ponto de um só agente entender vantajoso, independente da atuação do grupo, envidar os esforços tendentes à obtenção do resultado) ou como grupos intermediários (em que, embora a vantagem não se mostre tão intensa a ponto de convencer um ou alguns dos membros do grupo a empreender isoladamente na busca do benefício, há incentivos para que os membros do grupo se organizem e se coordenem para obter o benefício coletivo). Assim, há alta probabilidade de que os agentes econômicos organizem-se com vistas a tutelar os seus interesses perante a agência reguladora, envidando os esforços necessários para obter a decisão que mais lhes beneficiem. Porém, o mesmo não ocorre com os demais grupos que suportam os efeitos da regulação. Normalmente, envolvem grandes grupos (como o é, por exemplo, o grupo de usuários ou de consumidores ordinários de determinada atividade), cujos integrantes não têm incentivos para empreender em favor da obtenção de regulação que lhes seja favorável. Há, pois, um descompasso entre o empenho dos grupos envolvidos na regulação (com vantagens consideráveis em favor dos agentes econômicos que suportam os efeitos da regulação), apto a comprometer a imparcialidade do responsável pela edição da regulação.

Ocorre que, ao lado das dificuldades inerentes à ação coletiva de grandes grupos, há outros fatores que podem contribuir para o comprometimento da imparcialidade no exercício da regulação. No presente trabalho, exploram-se três dessas circunstâncias: $(i)$ a inexistência de partes processuais em sentido estrito; (ii) a assimetria informacional; e (iii) os diferentes níveis de "poder" e "controle" exercido sobre a atividade alheia. Os itens subsequentes dedicam-se ao exame de cada um desses fatores.

\subsubsection{A inexistência de partes processuais}

Não se deve olvidar que, no âmbito do Poder Judiciário (lugar de origem e no qual o dever de imparcialidade tem especial importância ${ }^{163}$ ), a tutela da imparcialidade

\footnotetext{
${ }^{163}$ Sobre o surgimento do dever de imparcialidade vinculado ao Poder Judiciário, confira-se MARIA TERESA DE Melo RiBeIRO, O princípio da imparcialidade da Administração Pública. Ob. cit., p. 20 e ss. Sobre as características específicas da imparcialidade do magistrado singularmente considerado, confira-se JUAN Montero ArocA, Sobre la imparcialidade del juez y la incompatibilidad de funciones procesales. Valencia: Tirant lo blanch, 1999.
} 
do juiz conta, em larga medida, com a participação das partes do processo. Se há causa de comprometimento da imparcialidade do juiz que beneficie a parte autora, é muito provável que a parte ré se insurja, adotando as medidas necessárias que inibam a proximidade do juiz da causa e o autor da demanda. Quanto a isso, cogitem-se das hipóteses de impedimento e suspeição do juiz (exemplo clássico de tutela de imparcialidade do magistrado). Caso alguma delas esteja presente e o juiz não a reconheça de ofício, a parte interessada poderá arguir a causa de impedimento e suspeição. ${ }^{164}$ Normalmente, a parte que se sinta prejudicada formulará a alegação. E por que essa é a postura provável (ou, quiçá, natural)? Porque em um processo judicial as partes atuam como tal. Têm interesses claramente identificáveis (diretos e imediatos) no processo. De forma muito nítida, conseguem perceber a necessidade e a utilidade da obtenção de uma decisão futura que tutele aquilo que defendem em tal sede. E evitar que o juiz esteja de antemão comprometido com a outra parte (o que provavelmente geraria uma decisão favorável ao ex adverso) é o primeiro passo para se equilibrar a disputa e tentar ter sucesso no final da demanda.

Ocorre que esse tipo de tutela da imparcialidade (concreto e deixado nas mãos das partes) tende a não funcionar com tanta eficácia no âmbito das agências reguladoras. ${ }^{165-166}$ Isso porque o mecanismo depende da existência de parte na estrita acepção do termo, ou seja, depende da presença de agentes que enxerguem, de modo nítido e imediato, a vantagem de se obter decisão que lhe seja favorável e o impacto de tal provimento sobre sua esfera pessoal.

Nos procedimentos das agências reguladoras, raras vezes se estabelece uma relação de partes efetivamente comprometidas com os interesses a tutelar. Excetuando as situações de adjudicação ou aquelas em que há conflito direto entre agentes econômicos interessados no setor (seja na qualidade de regulado, seja na qualidade de "grande consumidor" da atividade regulada), essa intensa contraposição de interesses não se coloca. Se, de um lado, há parte na exata acepção do termo (o agente econômico que tutela o seu

\footnotetext{
${ }^{164}$ Art. $138, \S 1^{\circ}$, do Código de Processo Civil Brasileiro; art. 112 do Código de Processo Penal Brasileiro.

${ }^{165}$ Com isso não se quer dizer que a sistemática do processo judicial seja uma solução ótima. É fato que, com a presença de partes efetivas, ele tende a funcionar melhor. Porém, ao fim e ao cabo, o sistema pode se revelar até mais frágil, já que o Judiciário não se submete a controles externos a ele (e, em compensação, os atos praticados pelas agências terão, sempre, a possibilidade de se submeterem a esse contraste externo, por meio do controle jurisdicional).

${ }^{166}$ Note-se que as causas de impedimento e de suspeição antes utilizadas como exemplo também se aplicam às agências reguladoras independentes, na qualidade de integrantes da Administração Pública Federal (art. 18 a 20 da Lei n. ${ }^{\circ}$ 9.784/99).
} 
negócio); de outro, tem-se interesses dispersos (interesses dos usuários, interesses na manutenção hígida da atividade regulada etc.), cuja representação não é muito bem definida e cujas vantagens ou desvantagens da decisão regulatória não são nítidas e(ou) não geram impactos muito significativos sobre a esfera pessoal de quem quer que seja. Assim, e aqui também se abre mais um espaço para que a imparcialidade possa a vir a ser prejudicada: o comprometimento do regulador na eventual tutela dos interesses do agente regulado pode ocorrer sem que a relação venha a ser contestada pela "parte" ex adversa. ${ }^{167}$

\subsubsection{A assimetria informacional}

Os agentes econômicos, ao se inter-relacionarem no mercado, não gozam dos mesmos níveis de informação. Quando a informação detida por um deles (e não conhecida pelos demais) é relevante para a transação econômica que as partes visam entabular, surge uma série de problemas econômicos (custos de transação, oportunismo contratual, moral hazard, seleção adversa, entre outros). ${ }^{168}$ Ocorre que não é somente nas trocas de mercado que essa diferença entre os níveis de informação figura com um dado relevante. O bom desempenho das atividades regulatórias depende, em grande medida, de o regulador deter informações sobre o setor sobre o qual exercerá regulação. E, nesse ponto, a assimetria informacional é relevante para o tema enfrentado nesta monografia.

Ao se tratar de regulação em um determinado setor econômico, cogita-se de

\footnotetext{
${ }^{167}$ Note-se que quando é possível identificar a polarização de posicionamentos, reduz-se a tendência de que prevaleçam os interesses dos grupos numericamente menores. Nesse sentido, NEIL KOMESAR destaca que, ao lado do modelo de ação coletiva acima exposto (por ele denominado como um modelo de força única), é possível construir um modelo de duas forças (two-force model). Nesse modelo - que não substitui, mas a complementa o anteriormente exposto -, pode haver situações em que grandes grupos se organizem e funcionem como uma "countervailling force", contrabalançando a influência detida pelos grupos menores numericamente. (Imperfect alternatives: choosing institutions in Law, Economics and Public Policy. Chicago and London: The University of Chicago Press, 1994, p. 65). A depender das características da situação concreta - o fato de, por exemplo, a regulação afetar consideravelmente um subgrupo que integra a maioria e esse grupo "ativar" a atuação do grupo como um todo -, é possível se assistir à atuação dos grupos maiores e menos organizados (Imperfect alternatives: choosing institutions in Law, Economics and Public Policy. Ob. cit., p. 82-84). Assim, "Where the majority is dormant and the majoritarian influence is negligible, we get the results of the IGTP [Interest Group Theory of Politics] - the same results as we would get from a one-force, minoritarian bias model. But as the majoritarian influence grows, we can get a contervailance of sorts between the two forces and, with it, political outcomes that are more 'balanced' than predicted by a model that focuses on only one force.(Imperfect alternatives: choosing institutions in Law, Economics and Public Policy. Ob. cit., p. 75)

168 Neste trabalho, não há espaço para aprofundar o exame dos problemas econômicos decorrentes da assimetria informacional. De toda a forma, deve-se destacar que o Prêmio Nobel de Economia de 2001 foi outorgado a George A AKerlof, Joseph E Stiglitz e A. Michael Spence pelos estudos que realizaram acerca de mercados em que a assimetria informacional se faz presente. Para uma visão geral acerca da relevância do tema, confira-se o texto de JOSEPH E. STIGLITZ, "Information and the change in the paradigm in Economics". Disponível em: <http://nobelprize.org/nobel_prizes/economics/laureates/_2001/stiglitzlecture.pdf $>$. Último acesso em: 1.10.2009.
} 
dois tipos de informação: um envolve as informações relativas ao conhecimento técnico sobre a área regulada e outro se refere às informações relacionadas aos fatos que devem ser regulados. Como MAX WEBER indicava ainda ao início do século, a tendência é a de as informações desses dois tipos detidas pelos agentes econômicos interessados no desenvolvimento de certa atividade econômica serem qualitativa e quantitativamente superiores àquelas recebidas pelas organizações burocráticas estatais:

Superior à burocracia, em relação ao conhecimento - conhecimento profissional e dos fatos, dentro do âmbito de seus interesses - é, em regra, somente o interessado privado com orientação aquisitiva, isto é, o empresário capitalista. Este constitui a única instância realmente imune (pelo menos, relativamente) à dominação inevitável do conhecimento burocrático racional. ${ }^{169}$

Nesse ponto, o tema adquire relevância para o exame do problema da captura. Na medida em que as agências reguladoras independentes são organizações estatais (pautadas, em grande medida, pela forma de organização burocrática) ${ }^{170}$, há a tendência que essa diferença informacional também se coloque entre elas e os grupos regulados.

Relativamente às informações referentes a conhecimentos técnicos, parece possível afirmar que essas são reputadas de extrema relevância para os grupos de interesse. Primeiro, e para evitar percalços no desenvolvimento das atividades (e, mesmo, na realização dos investimentos), é de todo adequado que os responsáveis pelo exercício da regulação detenham conhecimentos técnicos suficientes para que bem possam exercer a regulação. Decisões pautadas em critérios técnicos (em vez de substancialmente políticos) são mais previsíveis e permitem que investimentos sejam realizados com maior segurança. Ocorre que o conhecimento técnico não é nem unívoco, nem estático. É plenamente possível que determinada questão técnica possa ser abordada e resolvida de formas diferentes. Mais: é possível que as respostas hoje tidas como adequadas se revelem, em futuro próximo, equivocadas. ${ }^{171}$

\footnotetext{
${ }^{169}$ Economia e sociedade, vol.1, Ob. cit., p. 147.

${ }^{170}$ Sobre o tema, ampliar no item 2.3.3., abaixo.

${ }^{171}$ Quanto a isso, confira-se o alerta de ANTHONY GIDDENS, fazendo diversas referências à obra de Popper: “Algumas descobertas são, em determinadas épocas, muito bem estabelecidas e é sensato segui-las; por exemplo, deixar de fumar quase certamente reduz a chance de contrair uma série específica de enfermidades sérias. Mas, apenas quarenta anos atrás, muitos médicos recomendavam o fumo como um meio de aumentar o relaxamento mental e corporal. Muitas formas de conhecimento científico, particularmente quando elas são consideradas em conjunto com tecnologias observáveis, são relativamente seguras; a areia movediça está nivelada com um pouco de concreto. Todavia, tudo deve ser, a princípio, considerado sujeito a questionamento e, a cada momento, um quebra-cabeças de solicitações rivais, teóricas e práticas pode ser
} 
Diante dessas características, é possível afirmar que os grupos de interesse aplicam ativos (tempo e dinheiro) na tentativa de produzir conhecimento em seu favor e defender os pontos de vista que lhe são mais favoráveis. Essa postura não seria recente. BILAC PINTO faz referência à conduta adotada por prestadores de serviço de energia elétrica norte-americanos que, na década de 1920, não só promoviam “conferências por figuras proeminentes da indústria, [faziam] doações em dinheiro a algumas das principais universidades, destinadas à promoção de investigações acerca dos problemas relacionados com os serviços de utilidade pública e a suscitar estudo de professores, tudo isto visando obter atitude simpática da parte destes, para com a indústria”, mas chegavam a mapear a produção literária e acadêmica, incentivando as obras que lhes fossem mais favoráveis. ${ }^{172}$ No atualidade, e já agora em âmbito nacional, essa tendência também parece se fazer presente. Dentro dos limites do presente trabalho, colheu-se o exemplo da organização dos prestadores de serviços de telecomunicações. Primeiro, identificou-se que aflora número significativo de associações que congregam os prestadores de tais serviços ${ }^{173}$, ao que tudo indica, com o fito de tutelar os interesses de que compartilham. Esse último dado é evidenciado pelas informações disponibilizadas pelas referidas associações. Conforme

encontrado nas áreas 'movediças' do conhecimento". (Modernidade Reflexiva: política, tradicional e estética na ordem social moderna. Ob. cit., p. 109-110).

${ }^{172} \mathrm{O}$ trecho citado consta de Regulamentação efetiva dos serviços de utilidade pública. Atual. de Alexandre Santos de Aragão. 2a ed., São Paulo: Forense, 2002, p. 66. Quanto ao "tarifamento" das obras doutrinárias, BILAC PINTO faz extensa referência a inquérito produzido no âmbito da Federal Trade Commission acerca das práticas levadas a efeito pelas empresas responsáveis pela prestação de atividades equivalentes aos serviços públicos (Regulamentação efetiva dos serviços de utilidade pública. Ob. cit., p. 61-65).

173 Somente como exemplo, mencione-se a existência das seguintes organizações: TELEBRASIL Associação Brasileira de Telecomunicações; TELECOM - Associação Brasileira de Telecomunicações; ABEPREST - Associação Brasileira das Empresas Prestadoras de Serviços em Telecomunicações; ABECORTEL - Associação Brasileira de Empresas Construtoras de Redes e de Sistemas de Telecomunicações; ABRAFIX - Associação das Empresas Brasileiras de Telefonia Fixa; ACEL - Associação Nacional dos Prestadores de Serviço Móvel Celular; ABRANET - Associação Brasileira de Provedores de Internet; ABTA - Associação Brasileira de Telecomunicações por Assinatura; ABTM - Associação Brasileira de Empresas Operadoras de Telecomunicações Móveis; ABRAC - Associação Brasileira de Rádiochamada; ABL - Associação Brasileira de Editoras de Listas; SITEL - Sociedade Brasileira de Prestadores de Serviços de Teleinformações; ABERT - Associação Brasileira de Emissoras de Rádio e Televisão; ABIRD Associação Brasileira da Indústria de Radiodifusão; ABERIMEST - Associação Brasileira das Empresas Revendedoras, Instaladoras e Mantenedoras de Equipamentos e Sistemas de Telecomunicações do Estado de São Paulo; AESP - Associação das Emissoras de Rádio e Televisão do Estado de São Paulo; SET Sociedade Brasileira de Engenharia de Televisão; ASSESPRO - Associação das Empresas Brasileiras de Software e Serviços de Informática; ABDI - Associação Brasileira de Direito da Informática e Telecomunicações; APRITEL - Associação de Operadores de Telecomunicações; TELCOMP - Associação Brasileira das Prestadoras de serviços de telecomunicações competitivas; ABERCORTEL - Associação Brasileira da empresas de serviços de engenharia e telecomunicações; ABETEL - Associação Brasileira de Estudos Tributários das Empresas de Telecomunicações; ABR TELECOM - Associação Brasileira de Recursos em Telecomunicações; ABRAFORTE - Associação Brasileira para Fomento de Negócios em Redes de Telecomunicação; ABRASAT - Associação Brasileira das Empresas de Telecomunicações por Satélites; ABT - Associação Brasileira de Telesserviços; APTEL - Associação de Empresas Proprietárias de Infraestrutura e de Sistemas Privados de Telecomunicações. 


\section{divulgado pela TELEBRASIL - Associação Brasileira de Telecomunicações (que tem} como associadas outras tantas associações, como também uma série de prestadoras do serviço), o seu plano de ação é desdobrado em quinze pontos:

\section{Carga Tributária:}

01 - Atuar junto ao Senado Federal, aos Poderes Executivos Estaduais e à opinião pública, visando a diminuição da carga tributária para $15 \%$ do valor dos serviços. Essa atuação deverá ser apoiada por estudos específicos.

Fundos

02 - Examinar detalhadamente as repercussões da implantação dos novos Fundos de Incentivo (Universalização, Desenvolvimento), assim como do Fundo de Fiscalização (Fistel) e da aplicação dos respectivos recursos.

Canais de Comunicação

03 - Incrementar os canais de comunicação da Associação com a sociedade, através dos instrumentos de que a Telebrasil dispõe: revista, site Internet, televisão e rádio.

Painéis:

04 - Realizar os tradicionais painéis semestrais mantendo o alto nível do conteúdo e dos participantes, abordando preferencialmente temas da Agenda estratégica.

Estudos:

05 - Preparar estudo visando à participação das entidades privadas na gestão dos diversos fundos suportados por recursos oriundos das empresas do setor.

Incentivo Fiscal

06 - Gestionar junto ao Congresso Nacional visando à implementação do Artigo 74 da LGT que versa sobre o incentivo fiscal para as operadoras de serviços de telecomunicações.

Defesa do Associado

07 - Atuar, em nome de seus associados, junto aos Procons, visando esclarecer as matérias que redundam em descrédito para as operadoras, quando forem feitas de modo indevido.

Consultas Públicas

08 - Participar, com estudos próprios, através de consultoria específica e audiência aos associados, das consultas públicas emitidas pelos órgãos normativos, dando subsídios, sugestões e recomendações.

Ação junto ao Governo

09 - Criar e manter representação permanente junto ao Congresso Nacional e ao Ministério das Comunicações, para sensoriamento e contribuições a decisões que influenciem a atuação das entidades do setor.

Mídia

10 - Estudar e publicar artigos na mídia sobre temas importantes para o setor, em particular sobre os impactos do processo de desregulamentação e seu desenvolvimento.

Congresso

11 - Estudar e planejar a realização de congressos de âmbito continental, visando compatibilizar as políticas nacionais e o interesse comum dos países da região.

Banco de Dados

12 - Criar e manter banco de dados sobre estatísticas e informações gerais sobre o setor, em convênio com entidades que geram ou armazenam esses dados, disponibilizando-os a seus associados.

Recursos para o Setor

13 - Criar um mecanismo de ação junto aos órgãos financiadores de infra-estrutura, visando à ampliação dos recursos e do escopo de sua aplicação ao setor.

Bolsas

14 - Implementar uma metodologia de apoio à sustentação de teses de doutorado sobre assuntos de interesse para o setor nas principais universidades do País.

Recursos Humanos

15 - Implementar projetos específicos relacionados ao desenvolvimento de recursos humanos e da tecnologia utilizada no setor. ${ }^{174}$

${ }^{174}$ Disponível em <http://www.telebrasil.org.br/associacao/index.asp?m=plano-acao.htm>, último acesso em 28.11.2008. 
Ao que tudo indica, parcela desse plano de ação foi concretizada. Como exemplo, destaca-se a contratação de estudo que "servisse de base para sensibilizar o governo e a sociedade em geral” acerca da necessidade (ou não) de mudanças no marco regulatório ora vigente. Esse trabalho - denominado “(Tele) Comunicações 2015: Contribuições para o aperfeiçoamento do modelo" - foi distribuído aos associados, mas também "às entidades coirmãs, sindicatos afins, parlamentares, formadores de opinião, governadores, prefeitos e figuras representativas do Poder Executivo e do Governo, além de organizações do mundo acadêmico e de pesquisa."

Assim, e relativamente à informação quanto ao conhecimento técnico do setor, parece haver subsídios que permitem afirmar o emprego de esforços destinados a convencer o regulador quanto a aspectos relevantes atinentes ao exercício da regulação.

Porém, e ao lado disso, também se coloca questão relativa às informações quanto aos fatos que devem ser regulados (ou considerados quando do exercício da regulação).

175 Trecho disponível em <http://www.telebrasil.org.br/tel-inc-soc/index.asp?m=inicio.htm/>, último acesso em 28.11.2008. Nesse mesmo endereço, encontra-se a cronologia de formulação e divulgação do estudo. Quanto da última sucessão presidencial (2002), iniciativa similar já havia sido adotada. Elaborou-se um documento denominado "Livro Azul das Telecomunicações" e, segundo tal documento, "As medidas, contidas neste "Livro Azul", caso forem [fossem] incorporadas ao Plano de Governo durante a próxima etapa governamental, permitirão [permitiriam] consolidar as conquistas já alcançadas no setor das telecomunicações, superar suas atuais dificuldades e realizar plenamente o potencial do setor como instrumento para a conquista de um Brasil mais justo e desenvolvido". O excerto aqui citado é retirado do próprio "Livro Azul", com link de acesso no seguinte endereço: <http://www.telebrasil.org.br/publicacoes/ index.asp?m=livroazul.htm> (último acesso em 28.11.2008). Em linguagem coloquial, a página de apresentação de acesso ao documento chega a consignar que ele equivale a uma bíblia do posicionamento do setor privado relativamente às propostas de mudança para a indústria. Depois de indagar quais são os ajustes necessários para o setor, consigna que "Está tudo no Livro Azul (sic) editado pela Telebrasil com participação da Abrafix e Acel e apoio de 19 entidades ligadas às telecomunicações" (o texto aqui mencionado é acessado imediatamente por meio do último endereço eletrônico indicado). Também são constantes os apoios a congressos, simpósios e encontros relativos a temas do setor. Em consulta ao calendário de eventos nacionais de 2008 divulgados pela Telebrasil, são indicadas 159 ocorrências. Apenas duas delas poderiam ser tidas como, de fato, desvinculadas do setor (seriam elas, o seminário organizado pelo Instituto Fernando Henrique Cardoso e seminário realizado pelo Jornal do Brasil). Todas as demais envolvem atividades desenvolvidas por organismos destinados a ofertar o aprimoramento profissional dos indivíduos (entidades vinculadas ao sistema $\mathrm{S}$ ), por empresas particulares dedicadas à oferta de serviços educacionais ou por empresas de eventos contratadas para organizar seminários maciçamente patrocinados pelas empresas do setor. Os eventos e as entidades responsáveis por sua realização estão disponíveis no seguinte endereço eletrônico: http://www.telebrasil.org.br/eventos/index.asp?m=nacionais.htm, último acesso em 28.11.2008.

${ }^{176}$ A esse respeito, também pode ser consultado o trecho de entrevista feito por VERÔNICA PAULINO DA CRUZ com empregado de empresa de telefonia e transcrito em sua tese de doutoramento. De acordo com o empregado entrevistado, “As empresas investem em 'argumentação regulatória' (...) Chegamos lá (na ANATEL) com 22 técnicos. Qualquer detalhe que faltasse na hora, aquelas pessoas iam ter a informação. Agora pensa do outro lado, na agência, que a gente sabe tem falhas técnicas, não são tão bem preparadas, é uma carreira nova, as agências ainda são novas e por aí vai. Quer dizer, é uma briga muito esquesita. Só para você ter uma idéia, quando chegamos lá, eles não contestaram uma linha da minha apresentação (...)" ("Agências Reguladoras: entre mudanças institucionais e legados políticos". Tese de doutoramento em ciência política apresenta ao Instituto Universitário de Pesquisas do Rio de Janeiro. Rio de Janeiro, 2007) 
Não há dúvida que na relação regulador-regulado, o regulado, em princípio, dispõe de mais informações que o regulador. Essa assimetria informacional não parece ser mera suposição, mas efetivamente ocorrer. Não raro o regulador depende da informação detida pelo regulado (e só por ele conhecida por completo, já que envolve dados internos ao desempenho da atividade) para que possa editar a regulação. ${ }^{177}$ Como afirma ADAM PRZEWORSKI, "Em termos genéricos, o problema é o seguinte: a empresa regulada dispõe de informações sobre algumas condições, como seus custos de produção ou a demanda de seus produtos, que são superiores às informações de que dispõe o Estado (o agente 'regulador', entendido em sentido amplo, como políticos eleitos ou burocratas nomeados". ${ }^{178}$ Entre regulador-regulado cria-se uma inexorável diferença quantitativa e qualitativa de informações acerca das circunstâncias fáticas (inclusive, algumas vezes, acerca daquelas que devem ser submetidas à regulação), o que pode favorecer a ocorrência de captura. Nesse sentido, RoBERT BALDWIN e MARTIN CAVE:

(...) regulators require a good deal of information in order to carry out their functions -say to fix appropriate standards on issues such as acceptable pollution levels or price increases. The primary, and best, source of such information will often be industry. The regulator, accordingly, requires some assistance from the regulated firms in order to make $\mathrm{C} \& \mathrm{C}$ [command and control] regulation work. This gives the regulated firms a degree of leverage over regulatory procedures and objectives, a leverage that, over time, produces capture. ${ }^{179}$

Ainda em relação à assimetria informacional quanto aos fatos, deve-se destacar que, ao lado do diferente nível informacional que se estabelece entre regulador e regulado, é possível cogitar de sua ocorrência sob o ângulo de outra relação que se estabelece entre os sujeitos envolvidos no exercício da regulação, qual seja: a que coloca, de um lado, regulador-regulado e, de outro, os cidadãos. É possível que os processos e resultados das interações entre regulador-regulado não estejam integralmente disponíveis ao público. E se o público não dispuser de dados acerca do ambiente regulatório, torna-se mais fácil que haja um concerto entre os grupos de interesse e os editores da regulação, pois se cria um ambiente propício para que o slack de que trata MiCHAEL E. LEVINE possa ocorrer. $^{180-181}$

\footnotetext{
177 Não é ao acaso que a regulação por meio de agências reguladoras é denominada hetero-regulação, "porquanto é exercida por uma instância estadual sobre os agentes económicos" (VITAL MoREIRA, Autoregulação profissional e Administração Pública. Ob. cit., p. 52).

178 "Sobre o desenho do Estado: uma perspectiva agent $x$ principal”. Ob. cit., p. 47.

${ }^{179}$ Understanding Regulation: theory, strategy and practice, New York: Oxford University Press, 1999, p 36.

${ }^{180}$ Quanto à noção de slack, consulte-se o item 2.2.1, acima.

181 A diferença entre os dois níveis de assimetria informacional (regulador vs. regulado e regulador-regulado vs. cidadãos) é apontada por LÚCIA HELENA SALGADO, em "Agências regulatórias na experiência brasileira:
} 
Assim, a captura - aqui expressada por um controle em sentido forte exercido pelos agentes econômicos relativamente à agência reguladora ${ }^{182}$ - pode decorrer desse divergência. A partir de instrumentos informacionais (não somente no que concerne ao conhecimento técnico, mas especialmente no que se refere ao conhecimento de fatos), os regulados têm condições de persuadir o regulador que a melhor forma de atingir as finalidades a que deve se voltar a regulação envolve o alinhamento da regulação com os interesses dos regulados. Por vezes, a única informação disponível é aquela oferecida pelo regulado e, a partir dela, a solução que se lhe apresenta é a de editar determinada norma condizente com o interesse do regulado.

Note-se que aqui, diversamente do que se passa na explicação econômica do problema e na "teoria do ciclo de vida das agências reguladoras", não se põe em primeiro plano uma relação de troca entre regulador e regulado. ${ }^{183} \mathrm{O}$ regulador não tem condições de detectar que o problema está a ocorrer, pois crê que está atuando com vistas a obter a melhor solução possível diante da situação que lhe é posta (e, objetivamente, não dispõe de meios para perceber que sua atuação foi, ao fim, ditada pelo regulado). É justamente nesse ponto que o problema da captura se põe de modo mais significativo, pois esse modo de atuação tende à não-perceptibilidade e, portanto, a se manter incólume por tempo indeterminado.

\subsubsection{Os diferentes níveis de "poder" e "controle" exercido pelas (e sobre as) agências reguladoras independentes}

Por fim, é necessário avaliar se o "poder" que grupos de interesse exercem sobre os reguladores e o "poder" que esses reguladores são capazes de exercer sobre aqueles grupos são equivalentes. Caso não o sejam, pode haver desequilíbrio na relação

um panorama do atual desenho institucional" (Texto para Discussão. n ${ }^{\circ}$ 941, Rio de Janeiro: IPEA, p. 15-16. Disponível em: <www.ipea.gov.br>, último acesso em 06.05.2005)

182 A respeito da noção de "controle em sentido forte", ver item 2.3.3., abaixo.

${ }^{183}$ Note-se que mesmo na explicação da teoria do ciclo de vida das agências reguladoras essa troca se coloca. $\mathrm{O}$ regulador aceita se submeter ao regulado em troca da estabilidade e da segurança que tal relação lhe proporciona. Nesse aspecto, o que foi dito em outra oportunidade pela Autora desse trabalho (no texto "O problema da captura do regulador e o seu controle pelo Poder Judiciário: comentário a acórdão do Tribunal Regional Federal da 5a Região". Revista de Direito Pública da Economia. vol. 11, Belo Horizonte, 2005 , p. 211-252) merece ser mais bem esclarecido. Lá, indicou-se que a dependência informacional gerava, com o passar do tempo, uma relação de dependência generalizada e que tal poderia ser reconduzida à última das fases da teoria do ciclo de vida das agências reguladoras. Ainda se entende dessa forma, a dependência informacional generalizada e a última fase de vida das agências reguladoras podem ser equiparadas. Mas, só o podem, porque em ambas está-se diante do mesmo problema (a captura do regulador). Porém, e embora o resultado seja o mesmo, a origem dele é diversa, isto é, os caminhos que tomam as relações estabelecidas entre regulador e regulado são diferentes. 
que entre eles se estabelece. E, por conseguinte, existir a tendência de que um deles domine a atuação do outro e a correspondente facilitação da ocorrência de captura. ${ }^{184}$

Para explicar esse dado, o presente trabalho vale-se do conceito de MAX WEBER, segundo quem poder significa "toda a probabilidade de impor a própria vontade numa relação social, mesmo contra resistências, seja qual for o fundamento dessa probabilidade" 185 . No conceito weberiano, estão abrangidas tanto as hipóteses em que há obediência espontânea daquele que recebe a ordem relativamente àquele que a emite (seja porque concorda de antemão com a ordem, seja porque é persuadido para o cumprimento da ordem) quanto as situações em que a obediência é imposta - inclusive por meio do exercício de força.

Ao lado do conceito de poder, WEBER desenvolve a noção de dominação (Herrchaft). O conceito de dominação envolve não só a possibilidade de impor a própria vontade, mas especialmente a probabilidade de encontrar obediência à ordem emanada. $\mathrm{Na}$ relação de dominação, "há um mínimo de vontade de obedecer"186, que se ampara nos mais diversos motivos (desde hábitos inconscientes até razões puramente racionais), como também em um elemento qualitativamente distinto (e quiçá mais relevante): a crença na legitimidade da ordem. Tal como afirma JOAQUín ABELLÁn, no conceito de dominação "Weber destaca que no basta el mero resultado fáctico de que se produzca el cumplimiento de una orden dada, pues lo relevante en esa relación es la aceptación de la orden recibida como 'legítima', 'válida'”. 187

Essa “crença na legitimidade da ordem" significa que o receptor da ordem a pressupõe dotada de caráter obrigatório. ${ }^{188}$ Haveria, então, três tipos-ideais de dominação legítima: (i) dominação racional-legal: dominação baseada na crença na legitimidade das

\footnotetext{
184 Como afirma JULIA BLACK, "Regulation is dialectical: both regulator and regulatee are at once autonomous fo and dependent on each other" ("Constructing and contesting legitimacy and accountability in polycentric regulatory regimes”. $O b$. cit., p. 7). A questão que aqui se coloca é a de se saber se os níveis de dependência que o regulador mantém em relação ao regulado são similares aos que esse mantém em relação àquele.

${ }^{185}$ Economia e Sociedade. vol. I, Ob. cit., p. 33.

${ }^{186}$ Economia e Sociedade. vol. I, Ob. cit., p. 139.

187 JOAQUín ABELLÁN, "Estudo preliminar". In: WEBER, Max. Sociología del poder: los tipos de dominación. Madrid: Alianza Editorial, 2007, p. 19. Na versão brasileira de "Economia e Sociedade", fala-se em probabilidade de se obter obediência (p. 33). Na tradução de FERNANDO HENRIQUE CARDOSO e CARLOS ESTEVAM MARTINS, do mesmo trecho de "Economia e Sociedade" (denominado na obra organizada pelos AUTORES como "A dominação"), utiliza-se o termo possibilidade (CARDOSO, Fernando Henrique; MARTINS, Carlos Estevam. Política \& Sociedade. São Paulo: Editora Nacional, 1979, p. 16).

188 JOAQUín ABELLÁN, "Estudo preliminar". Ob. cit., p. 14.
} 
ordens estatuídas e no direito de mando daqueles nomeados para exercer a dominação; (ii) dominação tradicional: dominação baseada nos costumes vigentes, que se prestam a legitimar as ordens emanadas de acordo com essas tradições; (iii) dominação carismática: dominação baseada na crença que se tem nas qualidades extraordinárias de determinada pessoa. $^{189}$

Em relação à dominação carismática, é de se anotar que WEBER admite uma interpretação antiautoritária do carisma. Se, de início, a dominação carismática é interpretada como a crença em características excepcionais de determinada pessoa (o que normalmente dá origem a regimes personalizados e autoritários), esse tipo de dominação pode vir a ser reinterpretado de modo racional, o que lhe dá uma face antiautoritária. Sob esse último ângulo, o reconhecimento por parte dos dominados passa a ser causa da legitimidade do líder. Desse modo, "el líder ya no extrae su legitimidad de sus propias cualidades extraordinárias, sino de la voluntad de los dominados". ${ }^{190}$ Esta seria, segundo WEBER, "la base de la legitimidad democrática, que descansa en el principio de la elección". 191

Também de acordo com WEBER, a implantação da dominação não depende necessariamente da existência de um quadro administrativo que permita o seu exercício. Porém, o normal é que esse quadro se faça presente. ${ }^{192}$ A burocracia envolve, então, o "quadro administrativo" por excelência do tipo de dominação-legal racional. Nas próprias palavras de WEBER, “O tipo mais puro de dominação legal é aquele que se exerce por meio de um quadro administrativo burocrático". ${ }^{193}$ Dentre outros aspectos, a burocracia caracteriza-se pela organização hierárquica estabelecida por padrões estritamente legais, pela impessoalidade (separação absoluta dos meios administrativos e não-apropriação do cargo) e, em especial, pela qualificação profissional daqueles que exercem os cargos. ${ }^{194}$

\footnotetext{
${ }^{189}$ MAX WEBER, Economia e Sociedade. vol. I, Ob. cit., p. 141.

190 JOAQUín ABALLÁN, "Estudo preliminar”. Ob. cit., p. 46.

${ }^{191}$ JOAQUÍn ABALLÁN, "Estudo preliminar". Ob. cit., p. 46.

192 Nas palavras do próprio WEBER, “A situação de dominação está ligada à presença efetiva de alguém mandando eficazmente em outros, mas não necessariamente à existência de um quadro administrativo nem à de uma associação; porém, certamente - pelo menos em todos os casos normais - à existência de um dos dois" (Economia e Sociedade. vol. I, Ob. cit., p. 141).

${ }^{193}$ Economia e Sociedade. vol. I, Ob. cit., p. 144.

${ }^{194}$ Tal como afirma ALVIN W. GoulDNER, "Weber via nossa época como aquela em que o diletante estava desaparecendo rapidamente e assegurava que as formas modernas de administração se caracterizariam pela importância atribuída à especialização". ("Conflitos na teoria de Weber". Sociologia da burocracia, Tradução de CAMPOS, Edmundo.4ª ed., Rio de Janeiro: Zahar Editores, 1978, p. 61). Nas próprias palavras de WEBER, "Só existe escolha entre "burocratização" e "diletantização" da administração e o grande
} 
Quanto a esse último dado, Alvin W. Gouldner noticia que TAlCotT PARsons teria identificado um caráter equívoco na noção weberiana de burocracia. Segundo ele, WEBER teria unido no mesmo conceito (ou, nas palavras de GOULDNER, confundido) dois tipos diferentes de autoridade: $(i)$ a autoridade que repousa na "atribuição de um cargo legalmente definido" e (ii) a autoridade baseada na "competência técnica". ${ }^{195}$ Assim, a dominação legal-racional seria passível de ser exercida tanto em decorrência da crença na legalidade de atribuição do cargo, quanto com substrato na crença na competência técnica dos responsáveis pelo exercício do poder.

Fixados os referenciais teóricos de que se parte, é possível examinar de que modo se dá o exercício do poder pelas (e sobre) as agências reguladoras independentes.

Se é fato que o Estado detém o monopólio da força e, por isso, pode impor suas decisões à coletividade, também parece correto se admitir que, para seu funcionamento, não se deve pressupor o recurso da força em toda e qualquer ocasião. É de se esperar que a ordem venha a ser acatada, em alguma medida, por seus destinatários. Em suma: é de se esperar que o Estado exerça dominação.

Relativamente à Administração Pública, pode-se afirmar que, geralmente, ela é organizada de modo hierarquizado. Mesmo aqueles integrantes da denominada Administração Pública Indireta têm esse formato de organização, com a peculiaridade de que normalmente se sujeitam a recurso hierárquico impróprio com vistas à revisão de seus atos pela Administração Direta e a controle pela via da denominada "tutela administrativa". Há, portanto, alguma subordinação entre a Administração Direta e a Administração Indireta. Essas características permitem afirmar que a Administração Pública (Direta mais Indireta) compõe um todo escalonado hierarquicamente, cujo ápice é ocupado pelo Presidente da República. Essa posição superior do Presidente da República é característica dos regimes presidencialistas, em que "The function of a chief executive of a sovereing State, generally speaking fall into two categories - political and administrative". ${ }^{196}$ No Brasil, a função de chefia da Administração Pública Federal está expressamente contemplada no artigo 84, II, da Constituição Federal.

instrumento de superioridade da administração burocrática é o conhecimento profissional (...)" (Economia $e$ Sociedade. vol. I, Ob. cit., p. 146).

195 "Conflitos na teoria de Weber". Ob. cit., p. 63. GOULDNER não esclarece o que entende por "autoridade". De toda a forma, esclarece-se que o termo foi compreendido como sendo "aquele que detém a possibilidade de exercer dominação". Na hipótese da burocracia, dominação do tipo "racional-legal".

${ }^{196}$ Bernard SCHWARTZ, American Constitutional Law, Cambridge: The University Press, 1955, p. 109. 
Tal como organizada tradicionalmente, a Administração Pública envolve exemplo de dominação legal-racional, exercida por um quadro administrativo burocrático, organizado a partir de uma sucessão de competências outorgadas pelo ordenamento jurídico (isto é, a partir do escalonamento hierárquico). Porém, e tal como já descrito, a dominação legal-racional não envolve somente a convicção acerca da legitimidade das ordens estatuídas, mas também a crença no poder de mando daquele que coloca as ordens. Na medida em que é chefiada pelo Presidente da República - sujeito escolhido por meio de eleições livres ${ }^{197}$ - à dominação legal-racional exercida pela Administração Pública conjuga-se a dominação carismática em sua reinterpretação antiautoritária. Isso parece ser reconhecido pelo próprio WEBER quando afirma que, na dominação racional-legal, "Somente o dirigente da associação possui posição de senhor, em virtude ou de apropriação ou de eleição ou de designação de sucessão." 198 Ainda que toda a estrutura administrativa esteja organizada a partir de padrões legais e racionais, há um "senhor", cujo traço de legitimidade escapa a essa organização racional-legal e ampara-se na "apropriação" (isto é, na dominação carismática autoritária), na "eleição" (isto é, na dominação carismática de acordo com a reinterpretação antiautoritária) ou na "designação de sucessão" (isto é, na dominação tradicional). ${ }^{199}$

Ocorre que as agências reguladoras independentes parecem não se enquadrar com perfeição na descrição tradicional acima feita (e, consequentemente, na releitura feita a partir da conjugação dos tipos de dominação weberianos).

Primeiro, porque as agências são dotadas de independência (ou autonomia reforçada), caracterizada tanto pela impossibilidade de demissão ad nutum dos dirigentes das agências quanto pela não-submissão das agências ao Chefe do Executivo. Dessa forma, em face dos atos das agências não seria cabível recurso hierárquico impróprio, afastandose a revisão de seus atos pela Administração Direta. ${ }^{200}$ Logo, não se estabelece perfeita

\footnotetext{
197 Tal como alerta JOAQUín ABALLÁn, "No hay que perder de vista, en todo caso, que el concepto de democracia de Weber no está referido a la 'voluntad del pueblo' - de la que procediera la legitimación de los representantes elegidos -, sino simplemente a la elección libre de los dirigentes políticos, 'lo cual no es poco ciertamente"”. ("Estudo preliminar". Ob. cit., p. 46-47).

${ }^{198}$ Economia e Sociedade. vol. I, Ob. cit., p. 144.

199 Mesmo que as atividades desenvolvidas pelo Presidente sejam fixadas por meio de padrões legaisracionais, é inescapável que o traço de legitimidade - que permite falar em "dominação" em termos weberianos e em "poder de mando" - ultrapassa esses limites. Em outras palavras: a definição daquele que exercerá a atividade de Presidente (e não a definição da atividade ela mesma) encontra fundamento de legitimidade em lugar diverso do tipo-ideal de dominação racional-legal.

${ }^{200}$ Essas características - unidas às funções normativas, executivas e quase-judiciais que são outorgadas às agências - fazem com que as agências reguladoras tenham sido denominadas como um "quarto poder". Da
} 
vinculação hierárquica entre a agência e a Administração Central que, por conseguinte, não fica submetida à chefia do Presidente da República.

Depois, o modo de organização das agências reguladoras independentes tal como se dá com a Administração Pública Tradicional - envolve o escalonamento hierárquico de competências, remontando ao quadro administrativo burocrático que caracteriza a dominação racional-legal. Porém, diversamente da Administração Tradicional, não encontra no ápice o traço de legitimação outorgado pelo Chefe do Executivo, vez que não está a ele submetido. O topo da organização administrativa da agência é ocupado por um órgão colegiado (“Conselho Diretor”), formado por um corpo de técnicos que normalmente não advém dos quadros burocráticos. Em outras palavras: o órgão que deve corresponder ao ápice da organização da agência é, em verdade, externo à sua organização burocrática. De toda a forma, a seleção dos integrantes do órgão diretivo leva em conta a qualificação profissional (o conhecimento técnico na área de atuação) dos indivíduos que ocuparão os respectivos cargos. Os padrões de escolha dos dirigentes (isto é, daqueles que exerceram o poder de mando) são semelhantes àqueles que pautam as características de um "quadro administrativo burocrático". Todavia, não cabe plena identificação entre a "fonte" de legitimidade do quadro burocrático da agência e a do seu Conselho Diretor.

Isso porque, tal como afirma ANTHONY GIDDENS, “Aqui, precisamos separar o especialista do funcionário. Os funcionários são especialistas, em um sentido mais amplo do termo, mas a especialização, no contexto da ordem social moderna, é um fenômeno mais penetrante do que o funcionalismo". ${ }^{201}$ É possível, portanto, separar dois tipos de legitimação no âmbito da dominação legal-racional. De um lado, a legitimação decorrente da atribuição legal de um cargo. De outro, a legitimação decorrente do conhecimento técnico. Embora em uma organização burocrática os dois tipos convivam, fato é que a especialização acaba por se desprender da estrutura burocrática, de maneira que "pode, de várias maneiras, não corresponder à formação das hierarquias burocráticas que Weber tanto enfatizou". 202

identificação das agências reguladoras como um "quarto poder", confiram-se as referências de EDSON NUNES, "O quarto poder: gênese, contexto, perspectivas e controle das agências reguladoras", passim.

${ }^{201}$ Modernização Reflexiva: política, tradição e estética na ordem social moderna. Trad. de Magda Lopes, São Paulo: Editora Unesp, 1997, p. 105.

${ }^{202}$ Modernização Reflexiva: política, tradição e estética na ordem social moderna. Ob. cit., p. 106. Diante disso, GIDDENS afirma não só que a especialização tende a romper com a organização hierárquica, mas 
Diante do exposto, pode-se afirmar que a outorga de competências a todos os integrantes da agência reguladora (mesmo àqueles que a compõem sem pertencer à sua hierarquia burocrática) tem traços de dominação legal-racional. Porém, relativamente à estrutura burocrática da agência, o lastro de legitimidade mais relevante tende a ser a atribuição legal do cargo (embora a legitimação derivada do conhecimento técnico permaneça existindo). No que se refere à direção da agência, o lastro de legitimidade é quase que exclusivamente centrado no conhecimento técnico de seus ocupantes.

A observância dessa diferença entre o exercício de função administrativa pela estrutura tradicional da Administração Pública e pelas agências reguladoras independentes permite compreender melhor as dificuldades para que a agência reguladora se imponha em face dos setores regulados. Considerando que as agências reguladoras independentes exercem dominação integralmente pautada em padrões legais-racionais, pode-se afirmar que a sua autoridade (aqui compreendida como a possibilidade de exercer dominação) tem dois fundamentos: a atribuição de um cargo legalmente definido e a sua competência técnica. Porém, menos que da definição legal do cargo ${ }^{203}$, elas tentam afirmar a sua legitimidade a partir da sua competência técnica. ${ }^{204} \mathrm{E}$ exatamente nesse ponto, em eventual embate com os grupos regulados, a tendência é a de que a agência reguladora independente seja colocada em posição de desvantagem.

Tal como abordado anteriormente, as agências reguladoras são instituídas para regular setores econômicos estratégicos, nos quais, normalmente, as mutações

também que a burocracia tende negar a abertura necessária para a inovação (que é o "selo de garantia" da especialização), transformando habilidades em deveres (Modernização Reflexiva: política, tradição e estética na ordem social moderna. Ob. cit., p. 106).

${ }^{203}$ Tal como assinalado, o mais relevante para as agências reguladoras é o fundamento decorrente da competência técnica. De toda a forma, não se deve deixar de assinalar que extrair o fundamento de autoridade exclusivamente da atribuição de um cargo atribuído por lei também tem suas dificuldades, pois reconduz ao problema clássico do fechamento do sistema jurídico. Se sempre deve haver uma lei que atribua o cargo, a investigação extrapola os "limites" da agência, ultrapassa a legitimidade das normas colocadas pelo Parlamento e conduz ao "infinito" (NORBERTO BOBBIO, "Kelsen e il potere giuridico", Diritto e Potere: saggi su Kelsen, Napoli: Edizioni Sccientifiche Italiane, 1992, p. 124). É com vistas a esse problema a construção kelsiana acerca da pressuposição de norma hipotética fundamental, que tem por função o fechamento do sistema. A construção é criticada por BOBBIO, tendo em vista o todo da obra de KELSEN. De acordo com BOBBIO, a norma fundamental pode ter uma função metodológica, mas, ao fim , KELSEN pauta a validade do ordenamento jurídico na sua "eficácia continua" (portanto, um traço de poder efetivo). Confirase: "Kelsen e il problema del potere". Diritto e potere: saggi su Kelsen, Napoli: Edizioni Sccientifiche Italiane, 1992, p. 120

${ }^{204}$ É emblemático um dos títulos utilizados por MARÇAL JUSTEN FILHO, em sua obra $O$ direito das agências reguladoras independentes: "O surgimento das agências independentes como opção técnica” (p. 358). As dificuldades de uma opção como essa, inclusive diante da necessidade de que sejam considerados parâmetros diversos dos técnico-científicos no momento de tomada da decisão, também são destacadas pelo Autor ( $O$ direito das agências reguladoras independentes. Ob. cit., p. 376-379). 
tecnológicas são constantes. Precisam impor normas e controlar a atividade dos regulados. Controle esse que se vale da atividade da edição de normas (regulamentação e fiscalização) e tem como nota o "conhecimento técnico".

Aqui, portanto, há a outra dificuldade que se apresenta à agência reguladora.

FÁBIO KONDER COMPARATO, depois de examinar a origem etimológica da expressão controle, entende que ela pode ser utilizada em dois sentidos. Em um sentido fraco, que se remete às atribuições de regulamentação e de fiscalização da atividade de outrem; e, em um sentido forte, no sentido de poder de dominação ${ }^{205}$, determinando o conteúdo da conduta alheia (tanto no que se refere à escolha de fins quanto no que concerne à determinação de meios). ${ }^{206}$

A regulação exercida pela agência reguladora independente - por mais intensa e impositiva que se afigure - sempre se limitará a um conceito fraco de controle. Ela pode regulamentar determinado setor (e impor determinadas condutas) e, posteriormente, fiscalizar as regras que editou. Porém, não tem como fixar, in totum, a conduta tomada pelos agentes econômicos. Não tem como dominar todos os aspectos, determinando, de fato, a conduta do agente econômico. Pode até eleger fins ou prever meios que devem ser utilizados, mas fará isso por meio da regulamentação. Porém, ao fim, está limitada à possibilidade de fiscalizar a conduta do agente econômico. Mesmo se considerando que a fiscalização pode constatar o descumprimento da norma e abrir a possibilidade de aplicação da sanção não se admitiria que se está diante de um controle em sentido forte. Aliás, a cogitação quanto à aplicação de sanção demonstra justamente o contrário. A abertura da possibilidade de aplicação de sanção deriva, justamente, do fato de que não se tem dominação da conduta alheia (afinal, só se sanciona porque houve o descumprimento das regras e, portanto, a adoção de conduta diversa daquela que se esperava).

Ocorre que o mesmo não se dá com relação ao poder exercido por grupos de interesse sobre a agência reguladora. No limite, o poder exercido pelos grupos de interesse

\footnotetext{
${ }^{205}$ A expressão é aqui utilizada em sentido corrente, desvinculada da categoria weberiana antes exposta. O mesmo se dá nos parágrafos seguintes quando a expressão estiver vinculada à noção de controle em sentido forte.

${ }^{206}$ O poder de controle na sociedade anônima. Atual. de Calixto Salomão Filho, $4^{\mathrm{a}}$ ed., Rio de Janeiro: Farense, 2005, p. 29-32. Também adota essa diferenciação MARÇAL JUSTEN FILHO, $O$ direito das agências reguladoras independentes. Ob. cit., p. 28-29.
} 
sobre as agências reguladoras pode gerar situação de controle em sentido forte. Isto é, pode, de fato, implicar a dominação do modo de atuar da agência reguladora. As explicações da captura dadas pelas teorias expostas no capítulo anterior parecem confirmar essa circunstância. Sob o ângulo da teoria do ciclo de vida das agências, tem-se que, ao final da "vida" da agência, estabelecem-se laços tão estreitos entre regulador e regulado que a agência não reúne condições para se impor em relação aos grupos regulados. Sob o vértice da explicação econômica da teoria, a captura é característica inexorável da regulação. ${ }^{207} \mathrm{O}$ escambo entre regulador e regulado se estabelece de pronto e é característico do processo regulatório. O "deixar-se dominar" do regulador é, em verdade, a moeda de troca que tem a ofertar ao regulado (que está apto a lhe oferecer vantagens pecuniárias e pessoais). Por fim, a assimetria informacional entre regulador e regulado pode se traduzir em um meio para que essa dominação acabe por ocorrer. Quando o regulador não detém as mesmas informações que o regulado, passa a haver um vínculo de dependência entre o recebimento dessas informações e o bom exercício da regulação. Se as informações não são recebidas adequadamente pelo regulador, o resultado da regulação pode refletir a vontade dos regulados, ainda que não haja a consciência do responsável pelo exercício da regulação acerca desse dado.

Examinadas, em abstrato, as diferentes facetas que o problema da captura pode tomar, revela-se necessário analisar a realidade brasileira em que as agências reguladoras foram inseridas e de que modo ela exerce influência sobre a atuação das agências reguladoras. Na sequência, é necessário examinar se o impacto que a realidade brasileira pode exercer sobre as agências reguladoras facilita (ou não) a ocorrência do problema da captura. O próximo capítulo dedica-se a essa ordem de preocupações.

${ }^{207}$ Quanto à última vertente, FÁBIO NUSDEO afirma que "Segundo vários autores, dar-se-ia a captura da agência já no seu nascedouro, no momento mesmo de sua criação (...)" (Fundamentos para uma codificação do Direito Econômico. São Paulo: RT, 1995, p. 93). 


\section{CAPÍTUlO 3: O PROBLEMA DA CAPTURA E A REALIDADE BRASILEIRA}

Relações sociais, práticas culturais e contextos políticos geram efeitos significativos sobre o delineamento das oportunidades e das restrições para a adoção de condutas pelos indivíduos. $^{208}$

Tais elementos também atuam como condicionantes para o concreto funcionamento de novas organizações estatais, para a edição das normas regulatórias e para aplicação que a elas se dá. Tal como esclarecem JACINT JORDANA e DAVID SANCHO, "When certain models of regulatory designs are promoted for a specific country or sector, it is necessary to take in account that their institutions are embedded in a larger institutional constellation. It is this particular configuration and their characteristics that shape the regulatory policy process and regulatory outcomes". 209

Não se pode olvidar que as agências reguladoras são criadas no Brasil em meio a uma estrutura de Administração já posta, com a qual os atores (empresas, usuários, consumidores e Estado) estavam acostumados a lidar. Ou, na explicação de EDSON NUNES, “O regime regulatório que se pretendeu implementar, no entanto, revela permanências institucionais, a despeito da novidade anunciada. A inspiração em experiências internacionais serviu para motivar mudanças, mas teve de lidar com a realidade políticoinstitucional do país". 210

Em suma: quando da criação das agências reguladoras, já existiam mecanismos de relação entre Estado e sociedade que continuam a ser exercitados. A criação de novas estruturas, por si só, não é suficiente para alterar os modos de relacionamento Estado-sociedade. Nesse sentido, parece relevante examinar essas formas de interação já existentes na realidade brasileira, a fim de tentar verificar em que medida o contexto no qual as agências reguladoras foram inseridas pode incentivar (ou não) a ocorrência de captura.

\footnotetext{
${ }^{208}$ MiCHAEL WOOLCOCK. "Social capital and economic development: toward a theoretical synthesis and policy framework". Theory and Society. vol. 27 (2), apr-1998, p. 163.

209 "Regulatory designs, institucional constellations and the study of the regulatory state". In: JORDANA, Jacint. e LEVI-FAUR, David. The politics of regulation: institutions and regulatory reforms for the age of governance. Cheltenham: Edward Elgar, 2004, p. 315-316.

${ }^{210}$ EDSON NUNES [et. al.], Agências reguladoras e reforma do Estado no Brasil: inovação e continuidade no sistema político-institucional. São Paulo: Garamond, 2007, p. 249.
} 


\subsection{Os modos de interação Estado-sociedade existentes na realidade brasileira}

Segundo EDSON NUNES, há quatro formas de relação entre sociedade e Estado $^{211}$ no Brasil (quatro gramáticas): (i) clientelismo; (ii) corporativismo; (iii) insulamento burocrático; e (iv) universalização dos procedimentos. ${ }^{212}$

A noção de universalismo dos procedimentos liga-se ao modo liberal de organização do domínio público. Implica a edição de normas gerais, que podem ser utilizadas por todos os integrantes da sociedade. A partir delas, garante-se aos indivíduos a possibilidade de que elejam seus representantes, protejam-se contra os abusos de poder do Estado, formulem suas demandas perante o Estado e controlem o exercício dos poderes estatais por meio de mecanismos de checks and balances. A universalização dos procedimentos tende ao impersonalismo dos procedimentos. ${ }^{213}$

Embora esse seja um dos formatos de organização das relações Estadosociedade que se tentou implementar no Brasil a partir da década de 1930, fato é que ele não se instalou a esmo. Por um lado, de modo concomitante a esse formato organizatório, também foram implantadas legislações e instituições corporativistas. Por outro, as novidades colocaram-se ao lado do clientelismo, que pauta as relações estabelecidas no domínio público em laços pessoais e informais. ${ }^{214}$ Conforme sintetiza EDSON NuNES

\footnotetext{
${ }^{211}$ Não se olvida que a diferença Estado-sociedade pode remeter a uma diferença estanque entre públicoprivado que não é mais identificável com facilidade na realidade contemporânea (sobre essa questão, consulte-se GUNTHER TEUBNER, "Dopo la privatizzazione: il ritorno dei confliti politici nei private gvernments". Diritto policontestuale: prospettive giuridiche della pluralizzazione dei mondi sociali. Tradução de Beatrice Bodmer e Enrica Mazza-Teubner. Napoli: Edizioni Città del Sole, 1999, p. 145 e ss). Porém, recorre-se a essa distinção como recurso explicativo para expor, com maior clareza, os meios de interação entre agentes econômicos e autoridades estatais existentes no Brasil.

${ }^{212}$ A gramática política do Brasil: clientelismo e insulamento burocrático. $3^{\mathrm{a}}$ ed., Rio de Janeiro: Jorge Zahar Editor, 2003, p. 20.

${ }^{213}$ A gramática política do Brasil: clientelismo e insulamento burocrático, Ob. cit., p. 22-24.

${ }^{214}$ A definição de corporativismo e clientelismo não é tarefa simples. Os diversos estudos que se dedicaram aos temas controvertem sobre os aspectos mais relevantes de cada uma das figuras e, até mesmo, discordam quanto ao impacto (se positivo ou negativo) exercido sobre o desenvolvimento econômico brasileiro. Para um panorama acerca dos diversos estudos que se desenvolveram sobre os temas, consulte-se a tese de doutoramento de VERÔNICA PAUlino DA CRUZ, "Agências Reguladoras: entre mudanças institucionais e legados políticos". Ob. cit., p. 15-30. Para os fins estritos desse trabalho, entende-se corporativismo "as a system of interest and/or attitude representation, a particular modal or ideal-typical institutional arrangement for linking the associationally organized interests of civil society with the decisional structures of the state." (PHILIPPE C. SCHMITTER, "Still the century of corporativism?” Review of Politics 36 (1), 1974, p. 86). A par da possibilidade de ser interpretado como fenômeno de índole estatizante (subordinação de parcela da sociedade civil ao Estado) ou de índole privatista (abertura do Estado à representação de interesses organizados), uma das notas essenciais dessa noção é a de que esse modo de interação Estado-sociedade se dá por meios formais (a respeito, ver Edson Nunes, A gramática política do Brasil: clientelismo e insulamento burocrático, Ob. cit., p. 40-41). Por sua vez, clientelismo é aqui compreendido como "um tipo de relação entre atores políticos que envolve concessão de benefícios públicos, na forma de empregos,
} 
"Longe de destruir as bases locais e personalistas da República Velha, o regime do pós-30 sustentou-se nelas para conseguir apoio."215-216

\author{
Ainda no Governo Vargas, houve a tentativa de insular unidades \\ burocráticas responsáveis pela adoção de medidas estratégicas. Visava-se a afastá-las dos \\ partidos políticos, Congresso e demandas populares, tentando refrear o clientelismo (e o \\ personalismo a eles inerente) e privilegiar decisões técnicas na fixação de prioridades. ${ }^{217}$
}

Essa tendência se prolonga no período posterior (tanto no período

benefícios fiscais, isenções, em troca de apoio político, sobretudo na forma de voto" (JOSÉ MURILO DE CARVAlHo, "Mandonismo, coronelismo, clientelismo: uma discussão conceitual". Dados. vol. 40 (2), Rio de Janeiro, 1997. Disponível em: http://www.scielo.br/scielo.php?pid=S001152581997000200003\&script=sci_arttext. Último acesso em: 5.10.2009). Aqui, interessa destacar que essas trocas são generalizadas (isto é, envolvem o estabelecimento de uma relação pessoal entre concedente do benefício e favorecido, incluindo expectativas de promessas e benefícios futuros), bem como se valem de mecanismos informais de interação (a respeito, ver EDSON NUNES, A gramática política do Brasil: clientelismo e insulamento burocrático, Ob. cit., p. 27-28 e p. 40-41).

${ }_{215}$ A gramática política do Brasil: clientelismo e insulamento burocrático, Ob. cit., p. 48.

216 Rigorosamente, a prática clientelista já estava presente no momento de transição entre Império e República. A respeito, ver interessante texto de José MURILO DE CARVALHO, que examina as correspondências recebidas por Rui Barbosa quando Ministro da Fazenda. Conforme apurou o autor, 40\% das correspondências contemplavam algum pedido de favor. Desses, a maioria envolvia pedidos de emprego público e de promoção na carreira justificados a partir de relações de amizade, parentesco e coleguismo. ("Rui Barbosa e a razão clientelista". Dados. vol. 43 (1), Rio de Janeiro, 2000. Disponível em: http://www.casaruibarbosa.gov.br/dados/DOC/artigos/a-j/FCRB_JoseMuriloCarvalho_Razao_clientalista.pdf Último acesso em: 5.10.2009). Depois, expressões desse modo de atuação e de inter-relacionamento são encontrados ao longo de toda a história da República Brasileira, inclusive por meio de fatos sociais que, diante de suas características específicas descolam-se do clientelismo, podem ser tomados como fenômenos a parte. Isso ocorre relativamente à sociedade agrícola vivenciada na República Velha, VICTOR NUNES LEAL afirma que "O fenômeno de imediata observação para quem procure conhecer a vida política do interior do Brasil é o malsinado 'coronelismo"”. Isto é, "uma forma peculiar de manifestação do poder privado, ou seja, uma forma de adaptação em virtude da qual os resíduos do nosso antigo e exorbitante poder privado têm conseguido coexistir com um regime político de extensa base representativa. Por isso mesmo, o 'coronelismo' é sobretudo um compromisso, uma troca de proveitos entre o poder público, progressivamente fortalecido, e a decadente influência social dos chefes locais, notadamente dos senhores de terra." (Coronelismo, enxada e voto. Rio de Janeiro: Forense, 1948, p. 7-8). O mesmo se dá em relação à sociedade urbana que então se formava. De acordo com RAYMUNDO FAORO, desde a época colonial até a era Vargas, "A comunidade política conduz, comanda, supervisiona os negócios, como negócios privados seus, na origem, como negócios públicos depois, em linhas que se demarcam gradualmente" (Os donos do poder: formação do patronato político brasileiro. $3^{\mathrm{a}} \mathrm{ed}$. rev., Rio de Janeiro: Globo, 2001, p. 819). Relativamente à estrutura burocrática, não se tem um quadro burocrático naquilo a que o termo burocracia se remete (traços de legitimidade legal-racional, pautados em critérios neutros e objetivos). Diversamente, são os estamentos expressões de dominação patrimonialista - que se burocratizam, adotando as técnicas da burocracia como meras técnicas. As estruturas burocráticas brasileiras estariam mais próximas aos denominados estamentos burocráticos que à burocracia propriamente dita (Os donos do poder: formação do patronato político brasileiro. Ob. cit., p. 825). Quanto ao momento de intensificação da industrialização, a professora ELI DINIZ identificou a existência de aparente cooptação do Estado pelo empresariado, de molde que aquele passa a servir de instrumento para a consolidação dos interesses dos industriais da época. Segundo a AUTORA, "o alargamento do espaço político atribuído ao grupo empresarial pelo Estado se faria sobretudo por sua movimentação menos visível em torno de medidas parciais, englobando desde favores e incentivos individualmente negociados, até a pressão por definições em torno de medidas comprometidas com os interesses de todo um setor." (Empresário, Estado e capitalismo no Brasil: 1930-1945. Rio de Janeiro: Paz e Terra, 1978, p. 34).

${ }^{217}$ A gramática política do Brasil: clientelismo e insulamento burocrático, Ob. cit., p. 35. 
democrático pós-45, quanto no período de ditadura militar) e dá origem à criação de órgãos com competências específicas para o exercício da regulação. Assim, esse dado - existência de órgãos setoriais responsáveis pelo exercício da regulação - não é propriamente uma novidade no Brasil.

Como destaca Egon Bockmann Moreira, a era Vargas e o período pós1946 são marcados pela criação de órgãos responsáveis pela edição de atos regulatórios setoriais. $^{218}$ Em sentido similar, PEDRO DUTRA indica que "A criação de órgãos reguladores não é uma novidade nem na experiência estrangeira e nem na experiência brasileira". ${ }^{219}$ Segundo este autor, a criação de órgãos reguladores inicia-se em meados dos anos 30, perpassa a década de 1940 e de 1950 e atinge o período da ditadura militar.

Não se olvide que, nas décadas de 1940, 1950 e 1960 do século passado, foram criados o Conselho Nacional do Petróleo (Decreto n. ${ }^{\circ}$ 42.483/57), o Departamento Nacional de Energia Elétrica - DNAEE, o Conselho Nacional de Águas e Energia Elétrica, o Conselho Nacional de Telecomunicações - CONTEL (Lei n. ${ }^{\circ}$ 4.117/62), o Departamento de Aeronáutica Civil - DAC, o Departamento Nacional de Produção Mineral e o Departamento Nacional de Estradas de Rodagem - DNER (Lei n. ${ }^{\circ}$ 467/37 e Decreto-Lei n. $\left.{ }^{\circ} 8.463 / 45\right)$. Alguns deles dotados de competência normativa, ${ }^{220}$ ainda que sem as garantias que hoje se outorgam às agências reguladoras.

Embora possam contribuir para o impersonalismo que se tenta implementar pela universalização dos procedimentos, o ambiente em que esses órgãos administrativos atuam é de índole extremamente complexa. Em tais condições, "a informação é fortemente valorizada, e a coalizão formada com atores externos selecionados é vital para garantir tanto os recursos adicionais para a realização das metas como para solidificar a proteção do

\footnotetext{
218 "Anotações sobre a história do Direito Econômico Brasileiro". Revista de Direito Público da Economia. vol. 6, Belo Horizonte, p. 76-96, abr.-jun.2004.

219 “Agências reguladoras: reforma ou extinção?". Revista de Direito Público da Economia. vol. 3, Belo Horizonte, p.192, jul.-set.2003. Embora não afirme textualmente, tudo indica que ao fazer referência ao exercício da regulação, para o autor, a expressão abrange o exercício de algum poder normativo. A "impressão" é reafirmada na leitura do texto "Órgãos reguladores: social-democracia ou neogetulismo?". Livre concorrência e regulação dos mercados: estudos e pareceres. Rio de Janeiro: Renovar, 2003, p. 23-34.

${ }^{220}$ Confira-se, o art. $1^{\circ}$ do Decreto n. ${ }^{\circ} 42.483 / 57$ relativamente ao setor de petróleo; a atribuição outorgada ao DNER para regulamentar o transporte coletivo de rodagem (art. $2^{\circ}$, $d$, da Lei $.^{\circ}{ }^{4} 467 / 37$ ) e, quando transformado em Autarquia, para promover a revisão do Código Nacional de Trânsito (art. $1^{\circ}, f$, Decreto-Lei n. ${ }^{\circ}$ 8.463/45); a competência do DAC para elaborar os regulamentos e instruções da aeronáutica civil e comercial (art. $3^{\circ}$, item 3, do Decreto n. ${ }^{\circ}$ 19902/31); e as competências do CONTEL para o estabelecimento das normas técnica do setor (art. 29, $m, o, s$ e $z$, da Lei n. ${ }^{\circ}$ 4117/62).
} 
núcleo técnico contra ruídos originados no mundo exterior". 221 Quando se excluem o Congresso, os partidos políticos e as demandas populares da arena de formulação de políticas, isso não significa que essas unidades insuladas atuam de forma absolutamente impessoal. Além de se sujeitarem à centralidade do Poder Executivo, encontram parceiros relevantes nos integrantes da indústria (nacional e internacional). Em virtude de tal interação, associada à superveniência de regimes autoritários, formam-se os denominados anéis burocráticos, definidos por FERNANDO HENRIQUE CARDOSO do seguinte modo:

É, antes de mais nada, um mecanismo político pelo qual implicitamente se define que a Administração é supletiva aos interesses privatistas e estes fluem, em suas relações com o Estado, através de teias de cumplicidades pessoais. Note-se que, tipicamente, não se trata de lobbies, se entendermos por estes um tipo específico de grupo de interesses que suponham alto grau de organização dos grupos interessados numa decisão e racionalidade na definição de objetivos e meios. Em suma, os lobbies são instrumentos de pressão típicos de uma sociedade desenvolvida onde os interesses de grupo vão buscar influir nas decisões de um Estado bem organizado e que conta com uma burocracia moderna. No caso do Brasil no período nacional-populista, apenas se insinuavam organizações deste tipo, para pressionar decisões nos setores mais dinâmicos da economia, justamente onde as 'ilhas de racionalidade' de uma tecnocracia planejadora começam a formar-se. Em geral, entretanto, a teia de cumplicidades era mais difusa, mais orientada para relações e lealdades pessoais que tornavam cúmplices desde o vereador, o deputado, o funcionário de uma repartição o industrial, o comerciante ou banqueiro até o ministro, quando não o próprio presidente. A partir deste "sistema" as decisões eram tomadas e implementadas. A "burocracia" funcionava, portanto, como parte de um sistema mais amplo e segmentado: não existindo eficazmente partidos de classes, sindicatos ou associações de grupos e classes, os interesses organizavam-se em círculos múltiplos, em anéis, que cotavam perpendicularmente e de forma multifacética a pirâmide social, ligando em vários subsistemas de interesse e cumplicidade segmentos do governo, da burocracia, das empresas, dos sindicatos, etc. ${ }^{222-223}$

Esses anéis, portanto, são pautados em trocas tipicamente personalistas, demonstrando que o insulamento burocrático não ficou imune à realidade em que foi inserido. Para usar a expressão de EDSON NUNES, pode-se afirmar que as novas estruturas juntaram-se às já existentes em um "conjunto sincrético de instituições políticas" e, nesse contexto, “os 'anéis burocráticos' que ligam a burocracia técnica à burguesia internacional foram intensificados, e a burocracia insulada se distanciou da res publica, tal como as

${ }^{221}$ A gramática política do Brasil: clientelismo e insulamento burocrático, Ob. cit., p. 34.

${ }^{222}$ O modelo político brasileiro e outros ensaios. $2^{\mathrm{a}}$ ed., São Paulo: Difusão Européia do Livro, 1973, p. 99 100. Para um exame do papel dos anéis burocráticos na estruturação da Administração Pública e o seu parco relacionamento com a sociedade civil, ampliar em PAULO TODESCAN LESSA MATTOS, "O novo Estado Regulador no Brasil: Direito e Democracia". Tese de Doutorado apresentada à Faculdade de Direito da Universidade de São Paulo. 2004, p. 98 e ss.

${ }^{223}$ Ao comparar a noção de estamento burocrático de FAORO e a de anéis burocráticos de CARDOSO, PAULO TODESCAN LESSA MATTOS indica que essa última demonstra quão sofisticada é a relação que se estabelece entre a burocracia e a iniciativa privada. Porém, não parece haver contradição entre as duas idéias, mas complementariedade. As relações se tornaram mais sofisticadas e o planejamento econômico permitiu que se criassem ilhas de racionalidade no interior da burocracia estatal. Porém, "como essas 'ilhas de racionalidade' se formam dentro de uma estrutura administrativa tradicional, caracterizada pelo clientelismo político, elas não servirão ao interesse público, mas aos interesses privados que se organizam no interior do Estado e são catalisados a partir do Estado". (“O novo Estado Regulador no Brasil: Direito e Democracia”. Ob. cit., p. 99). 
instituições políticas clientelistas tinham feito no passado". 224

Dessas experiências anteriores, o relevante é destacar que já foram forjados mecanismos de relação entre Estado e sociedade que continuam a ser exercitados. A criação de novas estruturas, por si só, não é suficiente para alterar o modo de relacionamento Estado-sociedade. Sendo assim, não se pode olvidar que a criação de agências reguladoras se dá nesse contexto já existente e que, por suas características, podem incentivar a ocorrência de captura.

Entende-se que isso ocorre por duas ordens de motivos.

Primeiro, a experiência anterior demonstrou que os órgãos técnicos criados de forma insulada acabaram por desenvolver relações tipicamente personalistas. Como é cediço, essas formas de relacionamento comprometem a imparcialidade, pois fere diretamente a impessoalidade da atuação administrativa. Ocorre que a imparcialidade, além de traço central para o bom funcionamento das agências reguladoras, é a característica que se vê comprometida quando se está diante da captura de uma agência reguladora.

Depois, esse tipo de relação se estabelece de modo velado e informal, o que amplia a zona de penumbra em que a regulação é editada, facilitando a captura dos entes responsáveis por sua edição.

Parece correto afirmar que as características estruturais e funcionais de que são dotadas as agências reguladoras tendem a torná-las menos suscetíveis a essas ingerências. Não só a estabilidade dos dirigentes, mas os procedimentos a que sua atuação se sujeita permite afirmar que "o poder administrativo das agências difere do poder típico da burocracia hierárquica do executivo, visto que precisa ser feito às claras, com notícia pública e prazos para a intervenção das partes". ${ }^{225}$ Porém, também é correto afirmar que as novas instituições não ignoram a realidade em que se colocam e são por elas influenciadas. Nesse ponto do trabalho, o relevante é destacar que a realidade encontrada quando da instituição das agências reguladoras independentes era favorável à ocorrência do problema da captura. Mais que isso: a experiência histórica demonstra que desvios ainda mais profundos que a captura são de ocorrência recorrente na relação Estado-sociedade.

\footnotetext{
${ }^{224}$ A gramática política do Brasil, Ob. cit., p. 113.

${ }^{225}$ EDSON NunES, Agências Reguladoras e reforma do Estado no Brasil, Ob. cit., p. 266.
} 
Oportunamente, deve-se esclarecer que as referências aqui feitas não pretendem demonstrar ou defender qualquer vínculo determinista entre esses traços históricos e a ocorrência de captura. Em outras palavras: entende-se que essas características podem influenciar, contribuir e facilitar a ocorrência da captura, mas o problema não é delas decorrente de modo imediato e automático. Também se entende que esses traços podem influenciar o modo de organização das agências reguladoras e o seu relacionamento com os grupos de interesse (sejam os agentes econômicos, seja o Poder Central). ${ }^{226}$ Porém, daí não decorre o afastamento das vantagens inerentes à estruturação diferenciada das agências para o exercício das funções que lhe são cometidas. ${ }^{227}$

\subsection{O modus operandi da criação e da aplicação normativas}

Dos modos de interação entre Estado-Sociedade expostos no item anterior, sobressai, de forma nítida, o caráter personalista, informal e casuístico que permeia tais relações. ${ }^{228}$ A tendência é, portanto, a do "homem cordial", que prioriza (e tanto quanto

\footnotetext{
${ }^{226}$ A propósito, confira-se o texto de Mariana Da Mota PRADO, "Independent Regulatory Agencies, Patronage, and Clientelism: lessons from Brazil". Laboratório de Documentación e Análisis de la corrupción y la transparencia. Ciudad de México: Instituto de Investigaciones Sociais - IIS, 2006. Disponível em: http://www.derechoasaber.org.mx/documentos/pdf0103.pdf?PHPSESSID=f341dd5e3c563f62bb69f68fcf90a 350. Último acesso em: 20.12.2008.

${ }^{227}$ Quanto às vantagens da estrutura da agência reguladora relativamente à institucionalização dos mecanismos que tornam o exercício da regulação mais accountable, confira-se PAULO TODESCAN LESSA MatTos, "O novo Estado Regulador no Brasil: Direito e Democracia". Ob. cit., p. 230 e ss.

${ }^{228}$ Embora longa, é ilustrativa a explicação de SÉRGIO BUARQUE DE HOLANDA relativa ao primeiro período republicano:

"Não era fácil aos detentores das posições públicas de responsabilidade, formados por tal ambiente, compreender a distinção fundamental entre os domínios do privado e do público. Assim, eles se caracterizam justamente pelo que separa o funcionário "patrimonial" do puro burocrata conforme a definição de Max Weber. Para o funcionário "patrimonial", a própria gestão pública apresenta-se como assunto de seu interesse particular; as funções, os empregos e os benefícios que deles aufere relacionam-se a direitos pessoais do funcionário e não a interesses objetivos, como sucede no verdadeiro Estado burocrático, em que prevalecem a especialização das funções e o esforço para se assegurarem garantias jurídicas aos cidadãos. A escolha dos homens que irão exercer funções públicas faz-se de acordo com a confiança pessoal que mereçam os candidatos, e muito menos de acordo com as suas capacidades próprias. Falta a tudo a ordenação impessoal que caracteriza a vida no Estado Burocrático. $\mathrm{O}$ funcionalismo patrimonial pode, com a progressiva divisão e racionalização das funções e com a racionalização, adquirir traços burocráticos. Mas em sua essência ele é tanto mais diferente do burocrático, quanto mais caracterizados estejam os dois tipos. No Brasil, pode dizerse que só excepcionalmente tivemos um sistema normativo e um corpo de funcionários puramente dedicados a interesses objetivos e fundados nesses interesses. Ao contrário, é possível acompanhar, ao longo de nossa história, o predomínio constante das vontades particulares que encontram seu ambiente próprio em círculos fechados e pouco acessíveis a uma ordenação impessoal. Dentre esses círculos, foi sem dúvida o da família aquele que se exprimiu com mais força e desenvoltura em nossa sociedade. E um dos efeitos decisivos da supremacia incontestável, absorvente, do núcleo familiar - a esfera, por excelência dos chamados "contatos primários", dos laços de sangue e de coração - está em que as relações que se criam na vida doméstica sempre forneceram o modelo obrigatório de qualquer composição social entre nós. Isso ocorre mesmo onde as instituições democráticas, fundadas em princípios neutros e abstratos, pretendem assentar a sociedade em normas antiparticularistas." (SÉRGIO BUARQUE DE HOLANDA. Raízes do Brasil (edição comemorativa 70 anos). São Paulo: Companhia das Letras, 2006, p. 159-160 - original sem destaque).
} 
possível estabelece) relações pessoais em detrimento de atuações objetivas e imparciais. ${ }^{229}$ Essa necessidade de aproximação gera o afrouxamento dos ritos ${ }^{230}$ que, relativamente à aplicação normativa, se expressa tanto por meio de intensa produção de regras sem a adequada consideração da realidade sobre a qual a norma incidirá e sem um nível adequado de organização (inclusive para se saber quais são as normas em vigor e quais são as normas revogadas) quanto em interpretações que superam os textos normativos, correspondendo a uma verdadeira edição de normas ad hoc.

KEITH S. RosEnN dedicou-se a estudar o modus operandi da aplicação normativa brasileira. Depois de salientar os legados do período colonial e as características da cultura jurídica brasileira (paternalista, legalista e formalista), identificou a existência de dificuldade para, até mesmo, conhecer a lei aplicável a determinada situação concreta. Nas palavras do AUTOR,

Penetration of the formal system into even the modern, urban sectors is greatly hampered by difficulties in ascertaining its provisions. Caligula was reputed to have had his laws and decrees posted high off the ground where none of the populace could read them. The Brazilian method is not so obvious, but it is nearly as effective. Discovering the governing law in Brazil is still as perplexing and difficult a task today as in colonial times. ${ }^{231}$

Não fosse essa dificuldade, o Brasil conta também com uma peculiar forma de aplicação normativa. Ainda de acordo com RoSSEN, essa especificidade (o "jeito" ou “jeitinho") envolve o afastamento da norma formal, por meio de cinco formas: (i) a autoridade pública deixa de cumprir seu dever em troca de benefícios pecuniários ou de ganhos de status; (ii) o cidadão emprega subterfúgios para evitar a imposição de obrigação legal tida por justa em sentido objetivo; (iii) a autoridade pública condiciona o cumprimento do seu dever ao pagamento de vantagens pecuniárias e ganhos de status; (iv) o cidadão evita a incidência de determinada obrigação legal porque ela é irrealista, injusta ou economicamente ineficiente; e $(v)$ a autoridade pública desvia-se de seu dever legal porque, de acordo com a sua convicção, a lei é irrealista, injusta ou economicamente ineficiente. Se as três primeiras hipóteses podem ser rotuladas como práticas corruptas, as

\footnotetext{
${ }^{229}$ Quanto a isso, é emblemática a ilustração trazida por SÉRGIO BUARQUE DE HOLANDA sobre a reclamação de um negociante de Filadélfia, segundo quem, no Brasil e na Argentina, a conquista de um freguês dependia do estabelecimento de laços de amizade. (Raízes do Brasil, Ob. cit., p. 163).

230 SÉRgIO BUARQUE DE HolANDA dá conta do afrouxamento dos ritos relativamente à vida religiosa. Todavia, esse afrouxamento parece presente, também, no "rito" (rectius: procedimento) de aplicação da norma.

231 "The Jeito: Brazil's Institutional Bypass of the Formal Legal System and its Developmental Implications". The American Journal of Comparative Law. vol. 19, 1971, p. 539. Com alguma diferença de redação, o argumento é mantido na revisão do artigo ("Brazil's Legal Culture: The Jeito revisited". Florida International Law Jounal. vol. 1 (1), 1984, p. 30-31).
} 
duas últimas envolvem situações em que a alegação da busca de propósitos públicos é utilizada para afastar a incidência de obrigações legais (sem necessariamente haver uma troca de vantagens). ${ }^{232}$

Diante disso, "The legal norm is often only the starting point for negotiations that produce ad hoc solutions. Knowing the law is ordinarily not nearly as important as knowing the policy of a given regulatory agency, and, more importantly, knowing how to convince that agency to accord favorable treatment to your case." 233

Exemplo desse modo de proceder envolveu a aplicação dada ao Código de Águas na parcela em que pretendeu regular as tarifas de energia elétrica. A legislação limitava o retorno do concessionário a dez por cento do custo histórico (excluída a depreciação dos bens). A legislação, embora coerente com a realidade de outros países, era inadequada para o Brasil, que estava submetido a intenso processo inflacionário e precisava ampliar os investimentos no setor. Na aplicação da legislação, mesmo havendo determinação expressa para que houvesse o inventário dos bens das concessionárias, não foram fixadas as bases para aplicação do percentual definido na legislação. Portanto, não só estava ausente o parâmetro de aplicação do percentual, como também não havia referencial para a futura apuração da amortização dos investimentos. Depois, diante da inadequação do Código de Águas, em vez de se implantar a alteração da regulação de forma a adequá-la à realidade e à adoção de soluções estáveis para o setor, as mudanças foram pontuais, via "special temporary decrees", "jeito" e "extralegal negotiations". Por esses meios, foram concedidos aditivos, subsídios, financiamentos e toleradas dubiedades na contabilidade das concessionárias. Porém, a incerteza e a insegurança derivadas desses métodos inviabilizaram a realização de investimentos de longo prazo. Ao final das concessões, as redes estavam saturadas e já eram vivenciados cotidianos "black-outs". 234

\footnotetext{
232 "Brazil's Legal Culture: The Jeito revisited". Ob. cit., p. 3-4.

233 "Trends in Brazilian Regulation of Business". Lawyer of the Americas. vol. 13, 1981, p. 172.

234 "Brazil's Legal Culture: The Jeito revisited". Ob. cit., p. 40-41. Não bastasse isso, o afastamento ad hoc da legislação pela Administração acabou por impossibilitar que o Judiciário se valesse dos referenciais nela previstos, o que ampliou as bases da indenização deferida aos então prestadores de energia elétrica. Em acórdão recente (especialmente se se considerar o período em que tais concessões vigoraram), o Superior Tribunal de Justiça fixou o seguinte entendimento:

ADMINISTRATIVO. INTERVENÇÃO DO ESTADO NA PROPRIEDADE. EMPRESA EXPLORADORA DE ENERGIA ELÉTRICA. ENCAMMPAÇÃO DE BENS E INSTALAÇÕES. INDENIZAÇÃO. CÓDIGO DE ÁGUAS. APLICAÇÃO. IMPOSSIBILIDADE.

I - Sem a fixação de tarifas, de acordo com as regras do Código de Águas, inviabilizou-se a mensuração das amortizações, previstas no artigo 167, do Decreto $n^{\circ} 24.643 / 34$, máxime ante a falta de fiscalização e de regulação estatal.
} 
Essas características não só comprovam o privilégio dado ao modo de interação pessoal e informal, como também indicam as dificuldades que esse modo de atuar gera.

É fato que a instituição das agências reguladoras dotadas de autonomia tem por fim, justamente, gerar a credibilidade que esse modo de aplicação normativa bloqueia. Conforme destaca AleXANDRE GHEVEnTER:

$\mathrm{Na}$ América Latina, a autonomia torna-se a variável mais relevante para o provimento de credibilidade aos agentes econômicos privados sobre os resultados da política regulatória. A razão para isso é que os Estados latino-americanos são vistos como organizações fracas, incapazes de resistir a pressões por subsídios e proteção, particularmente vulnerável a pressões políticas, tanto na formulação quanto na implementação de políticas públicas, os resultados tendem também a ser muito incertos. A incerteza, em qualquer lugar do mundo, sempre existe; porém, uma coisa é lidar com a incerteza, dado um conjunto de regras. Neste caso, ao levar em consideração o espaço de atuação dos atores, é possível distribuir os resultados de forma probabilística. Outra situação ocorre em contextos em que as regras tendem a ser alteradas ou desrespeitadas: neste caso, os resultados possíveis não podem ser deduzidos das regras. A autonomia, neste particular, fornece certo grau de segurança contra formas de expropriação e arbitrariedade administrativa. ${ }^{235}$

Ocorre que, a despeito dos esforços de racionalidade e de construção de credibilidade - de que a instituição de agências reguladoras independentes é um exemplo-, as dificuldades verificadas nos estudos de ROSSEN continuam presentes. Somente a título do exemplo, destaque-se que recente relatório da OCDE, considerando os níveis federal, estadual e municipal, constatou haver mais de 3,5 milhões de normas em vigor no Brasil. Assim, continua a existir uma "legal confusion because there are texts that are obsolete, partially outdated or superimposed on other legal norms. This has led to legal uncertainty and conflict, creating unnecessary costs for businesses and citizens". ${ }^{236}$ Ou seja, ainda hoje, há dificuldades para se identificar o texto legal que, de fato, vigora. O que se dizer, então, da identificação da interpretação que a ele se dá ou do respeito que a ele se dedica.

Também essa característica favorece a ocorrência da captura da agência reguladora, pois, além de incentivar contactos ad hoc e informais, reduz a transparência da aplicação normativa, ampliando a zona de penumbra em que age o responsável pelo exercício da regulação.

II- Inaplicável o dispositivo de indenização do Código de Águas ante a falta de elementos suficientes para seu cálculo, resta a aplicação das regras de desapropriação, que eram tidas como válidas antes do Decreto $\mathrm{n}^{\mathbf{0}}$ 24.643/34. (Recurso Especial n ${ }^{\circ} 414.402$, $1^{\text {a }}$ Turma, Ministro FRANCISCO FALCÃO, DJ 31.05.2004, original sem destaque).

${ }^{235}$ Autonomia versus controle: origens do novo marco regulatório antitruste na América Latina e seus efeitos sobre a democracia. Belo Horizonte: Editora UFMG, 2005, p. 191.

236 "Brazil: strengthening for growth". Ob. cit., p. 36. 


\subsection{O problema da captura na realidade brasileira: excesso de autonomia ou falta dela?}

PETER Evans dedica-se a estudar o desenvolvimento econômico em países asiáticos, sul-americanos e africanos. Entende que, na atualidade, a atuação do Estado sobre o domínio econômico é um dado. Portanto, a questão apropriada não é de se indagar se deve haver mais (ou menos) intervenção, mas qual é o tipo de intervenção que deve ser levada a efeito, a fim de que seja possível atingir maiores e melhores níveis de desenvolvimento econômico. ${ }^{237}$

A partir da análise de casos concretos, o AUTOR defende que o melhor tipo de intervenção é a denominada "embedded autonomy". Embora conjugue termos contraditórios, a expressão traduz duas necessidades. Por um lado, requer que as instituições burocráticas responsáveis pelo exercício da regulação "are embedded in a concrete set of social ties that binds the state to society and provides institutionalized channels for the continual negotiation and re-negotiation of goals and policies". ${ }^{238}$ Porém, e de outro lado, essas organizações devem ter autonomia decisória, pois "Dense connecting networks without a robust internal structure would leave the state incapable of resolving 'collective action' problems, of transcending the individual interest of its private counterparts". 239 Desse modo, "Only when embeddedness and autonomy are joined together can a state be called developmental". ${ }^{240}$

Depois de sustentar que os níveis de desenvolvimento dos países do leste asiático (Coréia do Sul e Taiwan) comprovam a tese por si sustentada, PETER EvanS examina a situação do Brasil. Entende que o Brasil estaria em uma posição intermediária, ou seja, os níveis de desenvolvimento que apresenta não permitiram que fosse colocado ao lado daqueles países. Ao examinar o modo de organização da burocracia brasileira, identifica que um de seus problemas é a dificuldade que se instituir formas de recrutamento meritório para a composição dos quadros burocráticos. ${ }^{241}$

Segundo ele, o Estado Brasileiro é conhecido como um cabide de emprego, em que privilegiam as conexões pessoais em vez da competência. Para superar esse

\footnotetext{
${ }^{237}$ Embedded Autonomy, Ob. cit., p. 10.

${ }^{238}$ Embedded Autonomy, Ob. cit., p. 12.

${ }^{239}$ Embedded Autonomy, Ob. cit., p. 12.

${ }^{240}$ Embedded Autonomy, Ob. cit., p. 12.

${ }^{241}$ Embedded Autonomy, Ob. cit., p. 60 e seguintes.
} 
problema, em vez de uma transformação das organizações existentes, o Brasil houve por bem adicionar novas formas organizativas àquelas já existentes. Em outras palavras: o Estado foi modernizado por adição (e não por transformação). Com a criação de novos órgãos técnicos, criaram-se bolsões de eficiência, a fim de que as decisões administrativas relacionadas ao desenvolvimento econômico pudessem ser implantadas. Porém, "As long as pockets of efficiency are surrounded by a sea of traditional clientelistic norms, they are dependent on the personal protection of individual presidents." 242

A falta de uma burocracia estável faz com que as conexões entre órgãos responsáveis pela regulação econômica e setor privado relacionem-se por meio de canais individualizados (anéis burocráticos), nos quais "small sets of individual industrialists connected to individual bureaucrats". ${ }^{243}$ Há, aí, "the ad hoc, personalized character of these linkages" que "makes them both undependable form the point of view of industrialists and arbitrary in terms of their outcomes". 244

Assim, e usando como tipo-ideal ${ }^{245}$ a noção de embedded autonomy cunhada por EVANS, tem-se não só que o modo de interação entre Estado-sociedade (embedded) ocorre por meios inapropriados (usam-se canais individualizados em vez de canais institucionais), mas também que os órgãos responsáveis pelas decisões administrativas não são dotados da autonomia necessária para que possam fazer frente às dificuldades da tomada de decisões coletivas. Estabelece-se, desde logo, um vínculo de dependência desde o início em relação ao Poder Central e, na sequência, em relação aos grupos de interesse que inviabilizam a adoção e a implantação de decisões imparciais.

A questão que se coloca de imediato é a de saber se essa situação também ocorre em relação às agências reguladoras independentes. Em outras palavras: essas duas deficiências, encontradas rotineiramente nas organizações burocráticas tradicionais brasileiras, também são encontradas nas agências reguladoras independentes? Os últimos itens deste capítulo dedicam-se ao exame dessa questão.

\footnotetext{
${ }^{242}$ Embedded Autonomy, Ob. cit., p. 61.

${ }^{243}$ Embedded Autonomy. Ob. cit., p. 63.

${ }^{244}$ Embedded Autonomy. Ob. cit., p. 63.

${ }^{245}$ Acerca dos limites do recurso a tipos ideais, ver nota 26, acima.
} 


\subsection{Os canais institucionais de comunicação criados pelas agências reguladoras independentes}

Em termos comparativos, e em um plano abstrato, não é difícil constatar que a criação de agências reguladoras foi acompanhada pela previsão de novos canais (agora institucionalizados) de comunicação entre a sociedade civil e os entes responsáveis pelo exercício da regulação.

Em face da Administração Tradicional, mormente no período anterior à Lei de Processo Administrativo (Lei n. ${ }^{\circ}$ 9.784/99), havia, tão-somente, a previsão genérica do direito de petição. Diante da quantidade de instâncias decisórias ${ }^{246}$ e da ausência de previsões minimamente seguras acerca da tramitação dos eventuais pedidos formulados, criavam-se dificuldades tanto para aquele que formulava pleitos perante a Administração quanto para aquele que se dispunha a acompanhar a decisão que era dada aos pedidos formulados. $^{247}$

No âmbito das agências reguladoras, criam-se instrumentos que facilitam a comunicação e o acompanhamento das atividades regulatórias. Ao lado da realização de audiências e consultas públicas (que permite não só o vocalização de eventuais manifestações, mas que se conheçam as manifestações feitas pelos demais participantes), algumas agências preveem a presença de Conselho Consultivo e a instituição de ouvidorias. $^{248}$ Além disso, os processos administrativos a elas relativas são institucionalizados. Ainda que a lei de criação da agência, o decreto que a regulamenta ou o regimento interno da agência não estabeleçam os parâmetros do processo administrativo a ser obedecido, a Lei de Processo Administrativo (Lei n. ${ }^{\circ}$ 9.874/99) a elas se aplicará, fixando um rito mínimo a ser obedecido em seu desenvolvimento.

\footnotetext{
246 Conforme noticia PETER EvANS, em 1964, havia 200.000 cargos burocráticos (positions). Ao final do regime militar, havia 1.600.000 cargos (Embedded Autonomy. Ob. cit., p. 62). Na atualidade, até julho de 2009, somente o Poder Executivo contava com 1.019.825 cargos efetivos e 79.947 cargos e funções comissionadas. As informações atuais foram extraídas do Boletim Estatístico de Pessoal publicado pelo Ministério do Planejamento, Orçamento e Gestão (vol. 14, n. 160, ago-2009). Disponível em: http://www.servidor.gov.br/publicacao/boletim_estatistico/bol_estatistico_09/Bol160_ago2009.pdf. Último acesso em: 1.10.2009.

${ }^{247}$ Diante de tais dificuldades, privilegiavam mecanismos informais e personalistas de solução de problemas em detrimento da apresentação de pedidos formais, o que impedia, em absoluto, que se conhecessem as matérias decididas e os objetivos visados pelas medidas implantadas.

${ }^{248}$ Para um panorama completo sobre essas previsões legislativas, ver a obra de Leila Cuéllar, Introdução às agências reguladoras brasileiras. Belo Horizonte: Fórum, 2008, p. 155-163
} 
Assim, e ao menos em termos abstratos, é possível afirmar que uma das diferenças que as agências reguladoras independentes apresentam quando comparadas às organizações burocráticas tradicionais é o fato de que os seus mecanismos de decisão são diferenciados. Tanto há "preocupação com os mecanismos de controle das funções exercidas pelas agências reguladoras, sobretudo por intermédio do princípio da publicidade das decisões da agência e da exigência de justificação fundamentada do conteúdo das normas editadas" 249 quanto há "preocupação com a institucionalização de mecanismos de participação pública de usuários, consumidores e investidores de normas específicas ou na solução de controvérsias relativas à prestação do serviços". 250

Diante do exposto, e ao menos em níveis abstratos, é possível afirmar que as agências reguladoras independentes propiciaram a institucionalização de canais de comunicação, o que permite que a interação entre Estado e sociedade se dê por meios mais claros (e, por conseguinte, mais controláveis), representando uma vantagem em relação ao modus operandi que vigorava antes de sua instituição. Porém, e se é assim em relação à primeira parcela da equação de PETER EvANS (embedded), o mesmo não parece se dar com a segunda, relativa à autonomia. Ao que tudo indica, o modo de composição das agências reguladoras seguiu o padrão tradicional - a despeito das normas que visam conferir e garantir a autonomia e a imparcialidade da atuação das agências reguladoras independentes.

É o que se passa a analisar a seguir.

\subsection{Um comprometimento à brasileira da imparcialidade das agências reguladoras independentes: o uso da regulação técnico-econômica pelo Poder Central}

A construção teórica acerca da imparcialidade administrativa está intimamente ligada à necessidade de garantir a independência e a neutralidade da Administração Pública relativamente ao Governo e à atuação político-partidária. Segundo MARIA TERESA DE MElo RIBEIRO, “os autores são unânimes em considerar a despolitilização da Administração Pública como um dos fundamentos, senão mesmo o fundamento do surgimento do princípio da imparcialidade administrativa."

\footnotetext{
${ }^{249}$ PAUlo TOdescan Lessa Mattos, “O novo Estado Regulador no Brasil”. Ob. cit., p. 127.

${ }^{250}$ PAulo Todescan Lessa MatTos, “O novo Estado Regulador no Brasil”. Ob. cit., p. 127.

${ }^{251}$ O princípio da imparcialidade da Administração Pública. Ob. cit., p. 35. De acordo com UMBERTO ALEGRETTI, o dever de imparcialidade administrativa manifesta-se em três vertentes diferentes: a primeira é a
} 
A criação de agências reguladoras (e a imparcialidade que delas se espera) não destoa de tal construção. Tal como exposto anteriormente, a "razão de ser" da criação de agências independentes é a de evitar que temas de alta complexidade técnica e que envolvem decisões de longo prazo sejam submetidos à arena política pura e simples, onde estariam sujeitos a embates político-partidários e a contingências eleitorais. Portanto, menos que afastar a regulação dos interesses privados ${ }^{252}$, a criação das agências reguladoras pretende afastá-la das vicissitudes da política eleitoral.

Contudo, há elementos que permitem afirmar que esse objetivo nem sempre é atingido.

$\mathrm{Na}$ realidade norte-americana, há quem entenda que as agências reguladoras são, em verdade, controladas pelo Congresso. Depois de refutar a idéia segundo a qual não haveria "monitoramento" do Legislativo sobre a atuação das agências reguladoras (e que essa ausência de controle seria, por si só, suficiente para afastar a tese de que o Congresso exerce influência sobre as agências), BARRY R. WEINGAST e MARK J. MORAN examinam dados relacionados às decisões da FTC (Federal Trade Commission) e concluem que "little ostensible activity by Congress may mask more subtle but nonetheless strong congressional influence". ${ }^{253}$ Segundo os autores, o Congresso, por meio de seus comitês específicos, acaba por exercer um papel importante na tomada de decisões pelas agências reguladoras. Assim, menos que entidades independentes e com alto nível de discricionariedade, as agências reguladoras acabam por responder a uma espécie de controle congressional.

da necessidade de haver cisão entre o interesse pessoal do funcionário responsável pelo exercício da função administrativa e a função administrativa ela mesma; a segunda envolve a exigência de se retirar a função administrativa da égide do Governo, já que esse, na medida em que é expressão da função política, tende a transpassar o interesse partidário para a solução dos casos concretos; a terceira vincula-se à necessidade de se colocar o exercício da função administrativa a salvo das influências exercidas pelos grupos de interesse (L 'imparzialità amministrativa. Ob. cit., p. 22-28).

${ }^{252}$ Em verdade, o comprometimento do regulador com interesses privados é uma espécie de "externalidade" decorrente da criação das agências reguladoras. Utiliza-se essa expressão porque se entende que esse é um "efeito não-desejado" que se verificou em momento posterior à criação das agências reguladoras. O mesmo não se dá com a eventual ingerência político-eleitoral sobre regulação editada por agência reguladora. A tentativa de afastar essa última confusão é, justamente, um dos objetivos que pauta a criação das agências reguladoras.

253 "Bureaucratic Discretion or Congressional Control? Regulatory policymaking by the Federal Trade Comission". Journal of Political Economy. Vol. 91 (1), feb-1983, p. 793. Não obstante os dados examinados referirem-se somente ao FTC, os autores sustentam que "the results suggest that the same may also be true for other agencies (...)." ("Bureaucratic Discretion or Congressional Control? Regulatory policymaking by the Federal Trade Comission". Ob. cit., p. 793). 
Além da influência do Legislativo, fato é que, também nos Estados Unidos, as agências surgem como estruturas vinculadas ao Poder Executivo. ${ }^{254}$ A questão que de imediato se coloca é a de saber se o Congresso, quando da criação das agências reguladoras, poderia conceber uma entidade de índole administrativa completamente desvinculada do poder do Presidente da República ou se, na medida em que a agência integra o Poder Executivo, está submetida àquele poder. A experiência de mais de cem anos com as agências reguladoras e a interpretação que tem sido dispensada ao artigo II da Constituição Norte-Americana (relativo à organização do Poder Executivo e às atribuições do Presidente da República) têm redundado na afirmação de que "Probably the best answer is that as a general rule (and subject to important exceptions), Congress is without constitutional power wholly to immunize administrative officers exercising important discretionary policymaking authority from presidential control. Congress is therefore without power to create a "headless Fourth Branch" of government". 255

Nessa medida, há alguns espaços que se colocam desde logo e outros que foram construídos ao longo da experiência norte-americana, que permitem o exercício de supervisão do Presidente da República sobre as agências reguladoras.

Na experiência norte-americana, é necessário destacar a competência para a nomeação, para a escolha do diretor que exercerá as competências de presidente da agência - seleções que cabem ao Presidente da República - e, mesmo, para o afastamento do regulador. ${ }^{256}$ Quanto a esse último aspecto, se é certo que os dirigentes das agências reguladoras contam com mandato fixo e com a garantia da impossibilidade de demissão ad nutum, é igualmente correto afirmar que a estabilidade daí derivada é relativa, pois há situações (ou causas) que autorizam o afastamento do regulador. ${ }^{257}$

\footnotetext{
254 ThOmAs MoE. "Regulatory Performance and Presidential Administration". American Journal of Political Science. vol. 26 (2), may-1982, p. 198. No texto, o autor noticia que o ICC (primeira agência norte-americana de índole federal) foi inicialmente concebido para estar vinculado a um Departamento Interno, sujeito à supervisão do respectivo secretário. Foi a desconfiança do Congresso quanto ao comprometimento do Presidente da República com o setor ferroviário que motivou a criação da agência independente, alocada em um lugar sui generis da organização administrativa (THOMAS MOE. "Regulatory Performance and Presidential Administration”. American Journal of Political Science. vol. 26 (2), may-1982, p. 198-199).

${ }^{255}$ LAWRENCE LESSIG e CASS R. SunStEIN. "The President and the Administration". Columbia Law Review. vol. 94 (1), jan-1994, p. 113. Tal idéia já era anunciada no texto de PETER L STRAUSS e CASS R. SUNSTEIN, "The role of the President and OMB in informal rulemaking". Administrative Law Review. vol. 38, 1986, p. 204.

256 ThOMAS MoE. "Regulatory Performance and Presidential Administration”. Ob. cit., p. 198-200.

${ }^{257}$ CASS R. SUNSTEIN chega a afirmar que esse poder não é tão estreito como se costuma pensar. Para tanto, compara os entendimentos jurisprudenciais do caso Humphrey's Executor vs. United States e do caso Bowsher vs. Synar. O primeiro é o leading case da independência das agências reguladoras norte-americanas.
} 
Além dessas atribuições, há o controle orçamentário. Assim como as demais entidades da Administração, também as agências reguladoras independentes norteamericanas submetem o seu orçamento ao Executivo (por meio do Office of Management and Budget - OMB), que o concilia com as demais prioridades do Presidente. Além dessa compatibilização, o OMB monitora os gastos dos valores já "apropriados" pela agência, a fim de verificar a correta destinação dos valores. O entendimento do OMB é altamente respeitado e o Congresso (responsável último pelo Orçamento) dificilmente o contraria. Dessa forma, o OMB acaba por se revelar um meio capaz de influenciar as iniciativas e as preferências das agências reguladoras. ${ }^{258}$

Além desses meios de controle, outros foram construídos ao longo da história das agências reguladoras norte-americanas, de molde a instituir competências por meio das quais o Poder Central $^{259}$ pode fiscalizar o processo de regulação. Como provável reflexo das críticas a que as agências reguladoras foram submetidas na década de 70 do século passado (inclusive com a detecção da possibilidade de captura por parte dos regulados), o Governo Reagan (1981), por meio da Executive Order 12291, determinou que as agências reguladoras submetessem ao Diretor do OMB análise de impacto regulatório ("Regulatory Impact Analysis" - RIA) referente às regras mais importantes que viessem a editar. Assim, a RIA deveria ser apresentada ( $i$ ) para as regras que tivessem efeito econômico anual igual ou superior a US\$ 100 milhões; (ii) para aquelas que impusessem aumento nos custos ou nos preços para os consumidores, indústrias, agências

De acordo com o lá decidido, os diretores das agências não podem ser demitidos de forma desmotivada pelo Presidente. Diversamente, os diretores só podem ser destituídos for cause, compreendida essa como as situações de "ineficiência, negligência ou ilegalidade". No segundo caso, a Suprema Corte examinou os poderes outorgados ao Congresso para afastar o General Comptroller (chefe do "Government Accountability Office - GAO”, agência que assessora o legislativo no exercício das atividades de físcalização). Entendeu que não se poderia outorgar ao Comptroller a administração do Gramm-Rudman Statute (diploma legal que estabelece limites e mecanismos para controlar os déficits orçamentários) porque o Congresso tinha amplos poderes para afastar aquele agente público. Esses amplos poderes estavam consubstanciados na possibilidade de o Congresso afastar o General Comptroller em casos de "ineficiência, negligência ou ilegalidade". Segundo Sunstein, se no último caso a possibilidade de afastar determinado agente por conta de "ineficiência, negligência ou ilegalidade" revela uma considerável amplitude de poderes, não pode ser diferente quando se outorga a mesma cláusula para o afastamento dos dirigentes das agências reguladoras ("Paradoxes of Regulatory State". The University of Chicago Law Review. vol. 57, 1990, p. 439-440). O raciocínio é reproduzido no texto de LAWRENCE LESSIG e de CASS R. SunsteIn. "The President and the Administration”. Ob. cit., p. 111-112.

${ }^{258}$ THOMAS MOE. "Regulatory Performance and Presidential Administration”. Ob. cit., p. 201.

${ }^{259}$ A expressão é utilizada neste trabalho referindo-se à atuação do Presidente da República e Ministros de Estado. Preferiu-se utilizá-la a usar os termos "Poder Executivo" e "Administração Direta". A expressão "Poder Executivo" revelava-se muito ampla, já que as agências reguladoras independentes o integram. Assim, rigorosamente, está-se a falar do exercício de controle de uma parte do Poder Executivo sobre outra parte desse mesmo Poder. Por sua vez, a expressão “Administração Direta” apresentou-se muito estrita, pois se refere somente à função administrativa. Porém, parte das competências aqui mencionada é típica expressão de função governamental (portanto, política). 
governamentais ou regiões geográficas ; e (iii) para aquelas que tivessem considerável impacto negativo sobre a competição, o nível de emprego, o investimento, a produtividade ou a inovação. Por meio da RIA, a agência deveria apresentar análise de custos e benefícios da regulação, bem como o cálculo do benefício líquido que se pretende obter por meio de sua adoção. Além disso, a RIA deveria descrever as ações alternativas que poderiam gerar o mesmo resultado, assim como, na hipótese de as alternativas serem mais baratas que a regulação adotada, apresentar as razões pelas quais tal opção mais econômica não foi escolhida. Ao início do segundo governo Reagan (1985), essas regras foram complementadas pela Executive Order 12498, que estabelece o dever de a agência submeter ao Diretor do OMB um plano que contemple as políticas regulatórias, as metas e os objetivos para cada ano. Esse plano deve ser compatível com as finalidades da agência, mas também com os objetivos da Administração. Dessa forma, "Together, Executive Orders 12291 and 12498 went far, at least by design, to make the Reagan White House a central part of the process of agency rulemaking". 260

Esse maior controle das agências reguladoras estava inicialmente associado à agenda de desregulação e, portanto, atrelado aos Governos Reagan e Bush. ${ }^{261}$ Porém, e em que pese as Executive Orders acima referidas terem sido revogadas no Governo Clinton, regras muito similares foram por ele adotadas após tal revogação. Por meio da Executive Order 12866 (em termos similares ao que estava contemplado na Executive Order 12291 do Governo Reagan), o Governo Clinton exigia que as agências apresentassem análise de custo e benefício das regras regulatórias mais relevantes. Além disso, e de modo semelhante à Executive Order 12498 do Governo Reagan, ela também determinava que as agências submetessem seus planos regulatórios, as respectivas agendas e as regras mais relevantes que estivessem pendentes de implementação (pending major rules) ao $\mathrm{OMB}^{262}$

\footnotetext{
${ }^{260}$ Steven Croley. "White House Review of Agency Rulemaking: an empirical investigation". The University of Chicago Law Review. vol. 70, 2003, p. 825.

${ }^{261}$ STEVEn CROLEY. "White House Review of Agency Rulemaking: an empirical investigation". Ob. cit., p. 821.

${ }^{262}$ SteVen Croley. "White House Review of Agency Rulemaking: an empirical investigation". Ob. cit., p. 826-827. Ao levar a efeito pesquisa empírica acerca da atuação do Poder Central sobre as agências reguladoras, STEVEN CROLEY detecta que, proporcionalmente ao período de atuação, o Governo Reagan promoveu volume menor de modificações nas regras regulatórias editadas pelas agências reguladoras se comparado com o número de modificações feitas pelo Governo Clinton ("White House Review of Agency Rulemaking: an empirical investigation”.Ob. cit., p. 849).
} 
Embora a forma de influência "Congresso sobre agência" parece fazer mais sentido para a realidade norte-americana (em que, muitas vezes, as atribuições outorgadas às agências reguladoras são vistas como uma delegação de atuação que originalmente cabia ao Poder Legislativo ${ }^{263}$ ), as possibilidades de atuação do Poder Central sobre as agências reguladoras acima examinadas parecem encontrar similares no Brasil. O Poder Central detém poder para a nomeação dos diretores das agências, para a seleção do presidente da agência dentre os seus diretores, assim como possui competências quanto à destituição de tais diretores (embora não sejam de livre demissão, há possibilidade de afastamento nas hipóteses descritas em lei). Além disso, nos termos da Constituição, o Orçamento da União é unitário, de molde que cabe ao Executivo conciliar os valores atribuídos aos órgãos da Administração, às entidades integrantes da Administração Indireta (dentre as quais estão as agências reguladoras) e aos demais Poderes, submetendo o projeto de Lei Orçamentária ao Poder Legislativo. Por fim, e embora sem lastro claro para intervenção, há exemplos que demonstram a atuação do Poder Central sobre o próprio conteúdo da regulação.

A fiscalização por parte do Poder Central pode ter por objetivo compatibilizar as agências reguladoras independentes com o princípio da separação dos poderes e, mesmo, o de promover maior accountability em relação ao exercício da atividade regulatória. Porém, também é possível que tais competências de supervisão sejam desvirtuadas. Desse modo, de um controle em sentido fraco (expressado por meio da fiscalização e da supervisão), o Poder Central passaria a exercer controle em sentido forte, dominando a atuação da agência reguladora e produzindo espécie de "captura política". ${ }^{264}$ $\mathrm{Na}$ realidade brasileira, essa possibilidade afigura-se plausível ao se examinar as nomeações e os desligamentos dos diretores de agências, o processo orçamentário e o inter-relacionamento que se estabelece entre as agências e os Ministérios.

Relativamente à escolha dos dirigentes, tem-se assistido à politização das nomeações. Tal como noticia MARIANA MOTA PRADO, as primeiras nomeações da ANATEL e da ANEEL envolveram partilha de cargos entre PSDB e PFL, partidos aliados

\footnotetext{
${ }^{263} \mathrm{O}$ debate do momento da criação das agências torna isso claro: a discussão era a de se saber se a regulação econômica ficaria a cargo do Congresso ou se se criariam instituições específicas para esse fim. A propósito, confira-se o Capítulo 1, acima.

${ }^{264}$ Sobre a diferença entre os dois significados da expressão controle, confira-se o exposto no item 2.3.3, infra.
} 
ao Governo de Fernando Henrique Cardoso. ${ }^{265}$ A prática permanece no Governo Lula, em que as funções de direção das agências reguladoras integram as "cotas de distribuição de cargos" entre aliados políticos. ${ }^{266}$ Aliás, relatório da Organização para Cooperação e Desenvolvimento Econômico (OCDE) acerca da experiência brasileira com agências reguladoras, baseado em levantamento feito por GESNER DE OLIVEIRA e THOMAS FUJIWARA, detecta o aumento da politização das nomeações nas agências regulatórias no período compreendido entre 2002 e 2005 . $^{267}$

No que concerne às demissões, em que pese o Poder Central não ter utilizado as competências que são a ele outorgadas, valeu-se de meios indiretos de convencimento para obter o afastamento dos dirigentes. ${ }^{268}$ Dois exemplos demonstram esse modo de agir.

O primeiro envolve a renúncia do então presidente da ANATEL, Luiz Guilherme Schymura. Em junho de 2003, houve embate entre o Poder Central e a ANATEL relativamente ao aumento das tarifas de telefonia. O Poder Central pressionava por reajuste tarifário inferior ao previsto nos contratos de concessão, enquanto a ANATEL defendia o respeito à avença contratual. ${ }^{269}$ Em dezembro de 2003, valendo-se de disposição legal que permite ao Presidente da República escolher o presidente da agência (art. $5^{\circ}$, par. único, da Lei n. ${ }^{\circ}$ 9986/2000), Luiz Guilherme Schymura foi afastado da função. Na prática, ele passaria a atuar no Conselho Diretor da agência e outro conselheiro assumiria a função de presidente. Diante de tal situação, o então presidente da ANATEL renunciou ao cargo

265 "The challenges and risks of creating independent regulatory agencies: a cautionary tale from Brazil". University of Toronto Legal Studies Series: Research Paper $n^{\circ}$ 983.907, apr-2007. Disponível em: http://ssrn.com/abstract=983807. Último acesso em: 20.12.2008, p. 44.

266 "Loteamento das agências". O Estado de S. Paulo. Edição de 18.06.2008. "Loteamento político mina as agências reguladoras". Valor Econômico. 19.01.2005. A última notícia referida dá conta de que foi nomeado para a Agência Nacional de Águas (ANA) o Sr. José Machado, ex-líder da bancada do PT na Câmara e exprefeito de Piracicaba (que não conseguiu se reeleger); para a Agência Nacional do Petróleo - ANP, foi indicado o Sr. Haroldo Lima, ex-deputado do PC do B; na ANTT, foi nomeado o Sr. José Cirillo, presidente do PT-Ceará e que não foi eleito para o Governo daquele Estado.

267 "Brazil: strengthening for growth". OECD Review of Regulatory Reform. Paris: OCDE, 2008, p. 214. O estudo se deu mediante a comparação dos currículos dos dirigentes das agências reguladoras. Todo o currículo que continha formação ou experiência na área de atuação da agência foi considerado como nomeação técnica. Assim, o aumento da politização referido envolve as nomeações com substrato exclusivamente político (excluídas, portanto, as nomeações políticas, mas que contavam com algum respaldo técnico).

${ }^{268}$ MARIANA Mota PRADO, "The challenges and risks of creating independent regulatory agencies: a cautionary tale from Brazil". Ob. cit., p. 34-35.

269 "Lula se opõe ao reajuste das tarifas". Gazeta Mercantil (versão on line). Edição de 26.06.2003, 17:00h. Disponível em: HTTP://indexet.gazetamercantil.com.br/arquivo/2003/06/26/70/TELECOM:-Lula-se-opoeao-reajuste-das-tarifas.html. "Anatel contraria Lula e autoriza reajuste de $28,75 \%$ na tarifa de telefone". Folha Online. Edição de 26.06.2003, 22:07h, Disponível em: <http://www1.folha.uol.com.br/folha /dinheiro/ult91u69415.shtml> 
de conselheiro. Entende-se que a atuação do Presidente da República implicou, por vias indiretas, o afastamento de Luiz Guilherme Schymura do Conselho Diretor da ANATEL, já que era público e notório que o objetivo de Schymura era exercer a presidência da agência. Retirá-lo do cargo muito provavelmente implicaria a sua renúncia (tal como efetivamente se deu). ${ }^{270}$

O segundo exemplo envolve a renúncia de todos os diretores da ANAC em meio à denominada “crise aérea". Esse período, compreendido entre 2006 e 2007, teve início com as dificuldades financeiras da Varig. Em virtude de tais obstáculos, a Varig deixou o mercado, o que representou drástica redução da oferta de voos domésticos e internacionais. Os problemas foram agravados pela ocorrência de acidente aéreo de grandes proporções (“acidente da Gol”), a partir do qual se passou a colocar em causa a qualidade dos serviços de operação aeroviária no país. Em tal período, a demanda crescente (já submetida à drástica redução da oferta com a saída da Varig do mercado) trouxe a lume as restrições das infraestruturas aeroviária e aeroportuária brasileiras (que estavam sujeitas a limitações físicas, operacionais e de gestão). A crise tornou-se ainda mais profunda com a ocorrência de outro grave acidente aéreo ("acidente da TAM"). Embora o desastre não possa ser imputado à atuação regulatória do setor, fato é que o novo acidente colocou foco na atuação da ANAC e de seus diretores.

A primeira renúncia de diretores da ANAC ocorreu em momento posterior ao "acidente da TAM", depois da denúncia de que a ANAC teria apresentado "norma inexistente" no bojo de processo judicial que discutia as condições de operação do aeroporto de Congonhas. ${ }^{271}$ Quando dessa primeira renúncia (agosto de 2007), já eram noticiadas articulações políticas para obter o afastamento dos demais diretores. ${ }^{272}$ Se, por um lado, não há dados consistentes que permitam afirmar a existência dessas articulações e o modo como ocorreram; por outro, é fato que, em setembro de 2007, quatro dos cincos

\footnotetext{
${ }^{270}$ Em declarações à imprensa, Luiz Guilherme Schymura destacava que não aceitaria atuar somente como conselheiro da agência. Conforme salientava a Gazeta Mercantil no dia da renúncia de Schymura, o então Presidente da ANATEL voltara a afirmar que "deixa o cargo, pois, quando foi indicado pelo presidente Fernando Henrique Cardoso, estava claro de que ele só entraria na Anatel se fosse no cargo de presidente e que não teria cabimento mudar de opinião agora" ("Reguladoras: Schymura oficializa renúncia da ANATEL". Gazeta Mercantil (versão on line). 07.01.2004, 18:00h. Disponível em: http://indexet.gazetamercantil.com.br/arquivo/2004/01/07/22/REGULADORAS:-Schymura-oficializa-renun cia-da-Anatel.html).

271 "Pressionada, diretora da ANAC renuncia". Folha de S. Paulo. Edição de 25.08.2007.

${ }^{272}$ Conforme noticiou a Folha de São Paulo, o Ministro Nelson Jobim, "que trabalha nos bastidores para mudar toda a direção da agência, disse que a saída de Denise Abreu é o primeiro passo para repensar a Anac" ("Pressionada, diretora da ANAC renuncia". Folha de S. Paulo. Edição de 25.08.2007).
} 
diretores já haviam renunciado. ${ }^{273}$ Em novembro de 2007, ocorreu a renúncia do último diretor e então presidente da agência. A carta de renúncia foi divulgada pela imprensa. Nela, ao mesmo tempo em que o presidente da agência indicava as constantes pressões do Ministro da Defesa para que deixasse o $\operatorname{cargo}^{274}$, apontou o comprometimento da autonomia da agência decorrente daquela atuação ministerial:

A lei que criou a ANAC lhe deu autonomia administrativa. Se a decisão do Governo é caminhar para esta retirada, primeiro mude-se a lei, para que depois se tome as atitudes correspondentes, nunca o contrário, pois dessa forma estamos ferindo de morte a Constituição da República. O que estamos vendo até o presente momento é o mais absoluto desrespeito à legalidade, atropelando-se o princípio daquela autonomia dada pelo diploma legal. ${ }^{275}$

Pelo exposto, constata-se que a restrição formal à destituição dos diretores da agência dá lugar a formas de atuação indireta, que permitem ao Poder Central (por intermédio seja do Presidente da República, seja do Ministro de Estado) ter ingerência sobre o mandato dos dirigentes das agências. ${ }^{276}$ Tal modo de atuação é complementado por outro, consistente na omissão ou na demora das nomeações para os cargos de diretores das agências. Quando do encerramento dos mandatos, o Poder Central omite-se ou leva considerável tempo para a nomeação dos novos diretores, o que, levado ao limite, ocasiona a "paralisia decisória" da agência, isto é, a ausência das nomeações provoca o esvaziamento do órgão de direção responsável pelas deliberações colegiadas da agência. O relatório da OCDE indica que, em 2006, os cargos de direção das agências de infraestrutura ficaram vagos por, em média, 98 dias (isto é, 27,1\% do ano). ${ }^{277}$ Ainda de

\footnotetext{
${ }^{273}$ Tal como constou de notícia veiculada no jornal O Estado de S. Paulo, "Após quase um ano de crise aérea, quatro dos cincos diretores da Agência Nacional de Aviação Civil (ANAC) renunciaram a seus cargos. Agora, apenas o presidente da agência, Milton Zuanazzi, continua no cargo e resiste às inúmeras pressões. Já pediram demissão Denise Abreu, Jorge Velozo, Leur Lomanto e Josef Barat - que entregou a carta de renúncia na terça, 25. Todos eles deveriam ficar no cargo até 2011" "“Zuanazzi está sozinho na ANAC após renúncia do quarto diretor". O Estado de S. Paulo (versão on line). Edição de 26.09.2007, 08:23h. Disponível em: http://www.estadao.com.br/cidades/not_cid56989,0.htm)

${ }^{274}$ Essas pressões eram noticiadas pela imprensa ("Jobim reitera renovação completa da ANAC após saída de Barat". O Estado de S. Paulo (versão on line), Edição de 26.09.2007, 12:51h. Disponível em: http://www.estadao.com.br/cidades/not_cid57049,0.htm).

275 Trecho da carta de renúncia de Milton Zuanazzi divulgada na imprensa. Disponível em: http://www.anac.gov.br/arquivos/pdf/Carta\%20Milton\%20Zuanazzi.pdf. Último acesso em: 15.12.2008.

${ }^{276}$ A "atuação indireta" parece ligada aos traços encontrados na realidade brasileira examinadas nos itens anteriores desse capítulo. Traduzem mecanismos informais de atuação, com vistas à implementação de soluções personalistas e casuísticas.

277 "Brazil: strengthening for growth". Ob. cit., p. 215-216. Nos anos de 2003, 2004 e 2005, a média de tempo da vacância dos cargos de direção foi de 29, 84 e 58 dias, respectivamente. "Brazil: strengthening for growth". OECD Review of Regulatory Reform. Paris: OECD, 2008, p. 215-216. Os números utilizados pela OCDE têm origem em pesquisa realizada pela Associação Brasileira de Infraestrutura e Indústrias de Base (ABDIB) e envolveram apenas as agências de infraestrutura (Agência Nacional de Energia Elétrica ANEEL, Agência Nacional de Telecomunicações - ANATEL, Agência Nacional de Transportes Terrestres ANTT, Agência Nacional de Transportes Aquaviários - ANTAQ, Agência Nacional de Águas - ANA e Agência Nacional do Petróleo, Gás Natural e Biocombusíveis -ANP).
} 
acordo com o relatório da OCDE, uma das explicações para a delonga no processo de nomeação dos diretores é o fato de que os nomes indicados pelo Presidente da República devem ser aprovados pelo Senado Federal. Esse mecanismo que, em termos abstratos, serve de contrapeso ao poder de nomeação outorgado ao Presidente da República, acaba, na prática, por tornar mais lentos os processos de nomeação e ampliar a politização de tais escolhas. A aprovação pelo Senado exige, muitas vezes, o compromisso com número significativo de partidos, o que cria um impasse político nas nomeações. ${ }^{278}$

O orçamento também funciona como mecanismo de controle das agências reguladoras. No Brasil, além de vigorar a regra da unidade orçamentária ${ }^{279}$ (propiciando restrição similar àquela identificada nos Estados Unidos), os efeitos de tal restrição são ampliados pelo denominado "contingenciamento" de receitas. Por meio dele, parcela das receitas que deveriam ser destinadas às agências reguladoras (por exemplo, valores obtidos com taxas de fiscalização, concessões de licença etc.) deixa de ser a elas disponibilizado para permanecerem como "receitas" do balanço fiscal e contribuírem para a formação do superávit fiscal. Quanto a esses dados, os números relacionados à ANATEL são os mais significativos. Ao longo dos anos, a arrecadação da ANATEL cresceu consideravelmente. O que deveria significar um repasse significativo de verbas acabou por se traduzir na ampliação do contingenciamento. Se, em 1999, o percentual de repasse de valores era de $64,3 \%$ do total arrecadado, em 2005 , esse percentual foi de apenas $10,1 \%{ }^{280}$

Por sua vez, o modo de "atuação indireta" (que se identificou no afastamento dos dirigentes das agências reguladoras) é igualmente utilizado na tentativa de influir no próprio conteúdo da regulação ou no ato de sua aplicação. Além do já citado embate entre a ANATEL e o Poder Central quanto ao reajuste das tarifas de telefonia, podem ser mencionados o confronto entre o Ministro das Comunicações (Hélio Costa) e a ANATEL relativamente à licitação para o direito de uso de radiofrequências para Internet

278 "Brazil: strengthening for growth". Ob. cit., p. 215.

${ }^{279}$ De acordo com o artigo $165, \S 5^{\circ}$, I, da Constituição Federal, a lei orçamentária anual deve compreender o orçamento referente aos Poderes da União, seus fundos, órgãos, entidades da administração direta e indireta, inclusive fundações instituídas e mantidas pelo Poder Público. Ao mesmo tempo, a lei orçamentária anual é de iniciativa do Executivo (art. 165, III, da Constituição Federal) e a possibilidade de emenda pelo Congresso Nacional fica restrita à observância do contido no artigo $166, \S 3^{\circ}$, da Constituição.

${ }^{280}$ OCDE. "Brazil: strengthening for growth". Ob. cit., p. 229, Tabela 6.1. De toda a forma, deve-se destacar que os valores absolutos repassados à ANATEL são, em média, constantes (GESNER OLIVEIRA, THOMAS FUJIWARA e EDUARDO LUIZ MACHADO, “A experiência brasileira com agências reguladoras". Trabalho desenvolvido por iniciativa do Conselho de Infra-estrutura da Confederação Nacional da Indústria - CNI, Quadro 2.7. Disponível em: <www.goassociados.com.br/papers/Agencias_IPEA_Final.pdf>. Último acesso em: 20.12.2008) e que há agências (ANTT, por exemplo) em que o percentual de repasse passou a ser significativo nos últimos anos. (OCDE. "Brazil: strengthening for growth". Ob. cit., p. 229, Tabela 6.2.). 
em banda larga ${ }^{281}$ e o atrito entre o então Ministro de Minas e Energia (Silas Rondeau) e a ANEEL relativamente à questão da contabilização da eletricidade gerada por usinas termoelétricas. $^{282}$

Não fossem as "atuações indiretas", é possível identificar medidas diretas, adotadas por parte do Poder Central, ditando os termos próprios da regulação. MARIANA MotA MACHADO identifica dois exemplos. ${ }^{283} \mathrm{O}$ primeiro refere-se a divergências entre o Ministério de Minas e Energia e a ANEEL quanto à partilha de riscos em licitações para a construção de novas hidrelétricas. Inicialmente, a ANEEL divulgou Edital de Licitação indicando que os custos com eventos imprevisíveis poderiam ser repassados à tarifa final. Se, durante a construção da nova planta, sobreviesse evento imprevisível, o custo daí derivado seria compensado mediante aumento de tarifa. No dia seguinte ao da publicação da minuta do Edital, por meio de Portaria, o Ministério de Minas e Energia "instruiu" a ANEEL a alterar a regulação, de forma a atribuir ao investidor a assunção de tais riscos. A ANEEL acolheu a determinação e modificou o teor da regulação, amoldando-a à instrução ministerial.

O segundo exemplo envolve a alteração do critério de cobrança pelo serviço de telefonia. De acordo com Decreto n. ${ }^{\circ}$ 4.733/2003, a partir de 2006, as cobranças dos serviços de telefonia deixariam ser feitas "por pulso" e passariam a ser feitas "por minuto". A ANATEL "acolheu" o decreto e passou a formular os estudos necessários para implantar a modificação. Pouco antes do prazo final para se promover a alteração (fevereiro/2006), resolveu-se adiar a data de adoção das mudanças sob o argumento de que as alterações pretendidas prejudicavam os usuários de Internet com conexões dial-up. Em que pese uma das explicações possíveis para a ANATEL haver consentido com o adiamento ser a de que,

\footnotetext{
${ }^{281}$ Quando da licitação do direito de uso de radiofrequiência em banda larga, o Ministro de Comunicações pediu que a ANATEL adiasse a realização da licitação. Ao mesmo tempo, ameaçou intervir na agência caso a licitação fosse levada adiante sem que fossem promovidas as alterações fixadas pelo Ministério ("Hélio Costa defende intervenção na Anatel e adiamento de leilão". Gazeta Mercantil. Edição de 23.08.2006, p. C1).

${ }^{282}$ Por meio da Resolução 231, a ANEEL determinou que o potencial de geração das termoelétricas movidas a gás (e que não tivessem gás à disposição) fosse retirado da contabilidade geral da energia disponível. Por meio de tal medida, a agência entendia que promoveria um "mapeamento" mais preciso da disponibilidade de energia elétrica no país. Essa determinação foi criticada pelo então Ministro de Minas e Energia, que a ela se contrapôs por entender que a Resolução da ANEEL promoveria o aumento do preço da energia elétrica. Ocorreram, então, sucessivas discussões entre a ANEEL e o Ministro de Minas e Energia e, ao início de dezembro de 2006, adiou-se a aplicação da resolução para janeiro do ano subseqüente ("Aneel aprova medida que afeta preço de energia". Valor Econômico. Edição de 29.11.2006 e "Preservar a ANEEL". O Estado de S. Paulo. Edição de 04.12.2006).

${ }^{283}$ Os exemplos e as informações aqui expostas foram extraídos do texto de MARIANA Mota PRADO, "The challenges and risks of creating independent regulatory agencies: a cautionary tale from Brazil". Ob. cit., p. 21 e ss.
} 
de fato, ela concordava com o argumento do Poder Central, há outra razão mais plausível, qual seja: a ANATEL não atua de modo independente do Poder Central e, em algumas ocasiões, a regulação por ela editada serve a propósitos políticos. Nas palavras de MARIANA MOTA PRADO,

Another plausible hypothesis is that the agency is no longer independent from the government, which can be supported by a number of factors. First, Lula appointed two of the three directors who participated in the meeting where the decision was made. Second, the government was one of the stakeholders most interested in postponing the policy's implementation. In fact, in addition to the concern with digital inclusion policies, the government could have been concerned with the impact of this rate increase on inflation. Whereas the government had at least two reasons to postpone the policy's implementation, the consumers remained in favor of the shift (although opposed to the rate increase), and some companies had already spent substantial amounts of money since 2003 to make the necessary changes to the new system. Thus, except for the government, there were many stakeholders who wanted the shift. ${ }^{284}$

Essas experiências anteriores dão a percepção de que, por vezes, as agências reguladoras brasileiras funcionam como instrumento de ação dos Ministérios e da Presidência da República. ${ }^{285}$

Os mecanismos de fiscalização e supervisão do Poder Central sobre as agências reguladoras (controle em sentido fraco) podem ser interpretados positivamente, pois ampliam o accountability dessas agências e, em última análise, podem contribuir para o melhoramento da qualidade da atuação das agências reguladoras. Porém, na experiência brasileira, detecta-se que esses instrumentos são utilizados visando a fins políticos. As nomeações, o afastamento "indireto" de dirigentes, as restrições orçamentárias e, o que é mais grave, as ingerências sobre o próprio conteúdo da regulação revelam a "deturpação" dos mecanismos de físcalização e supervisão. Do exercício de controle em sentido fraco, identificam-se tentativas de exercer controle em sentido forte, buscando a dominação das agências com vistas a amoldar a regulação a finalidades estritamente políticas. ${ }^{286}$ Assim, também sob esse viés, há o comprometimento da imparcialidade da atuação da agência

\footnotetext{
284 "The challenges and risks of creating independent regulatory agencies: a cautionary tale from Brazil". Ob. cit., p. 24.

${ }^{285}$ Essa percepção transparece em pesquisa com os investidores dos setores de energia elétrica e de telefonia. Conforme pesquisa realizada pela Câmara Americana de Comércio (AMCHAM/SP) com tais investidores, entre 2004 e 2005, pelo menos a metade dos investidores do setor elétrico entendiam que a ANEEL era excessiva ou altamente influenciada pelo Poder Central. Por outro lado, nenhum entrevistado considerou "mínimo" o nível de influência do Poder Central. Resultado similar foi obtido em relação ao setor de telecomunicações (MARIANA MOTA PRADO, "The challenges and risks of creating independent regulatory agencies: a cautionary tale from Brazil”. Ob. cit., p. 25-26). Esse histórico de atuação coloca em dúvida o modo como será implantado o Programa de Fortalecimento da Capacidade Institucional para Gestão em Regulação (PRO-REG) instituído pelo Decreto $n^{0}$ 6.062/2007 ("Programa para agências reforça temor de ingerência". Valor Econômico. 20.03.2007).

${ }^{286}$ Sobre as diferenças entre controle em sentido forte e em sentido fraco, confira-se o item 2.3.3., supra.
} 
reguladora ("captura política"), que também pode pôr em causa o bom exercício da regulação, especialmente quando se tem em conta a finalidade por ela buscada: manutenção da atividade sob regulação, garantindo-se sua ampla disponibilidade (inclusive para as gerações futuras).

Tal como salientado em passagens anteriores, este trabalho compreende a captura como o comprometimento da imparcialidade de atuação do regulador. E, nesse sentido, a identificação do fenômeno independente de quem seja o responsável por esse desbalanceamento (se o grupo de regulados, se o Poder Central). Ou seja, compreende-se que a captura pode ocorrer para além da relação regulador-regulado e que limitá-la a essa relação seria uma excessiva simplificação. ${ }^{287}$

Identificadas as possíveis fontes de ocorrência da captura e o modo pelo qual a realidade brasileira pode contribuir para a ocorrência desse problema, a questão que se coloca é a de saber se o problema da captura é inexorável ao exercício da regulação. Em outras palavras: é necessário investigar se a opção pelo exercício de regulação por meio de agências reguladoras independentes implica, ipso facto, a ocorrência da regulação. $\mathrm{O}$ próximo capítulo dedica-se ao exame dessa questão.

\footnotetext{
${ }^{287}$ TONY PROSSER, "Theorizing utility regulation”. The modern law review. vol. 62, 1999, p. 204. Mesmo na realidade inglesa, a captura política foi identificada. Segundo TONY PROSSER, “(...) is certainly possible to suggest that the early stages of the regulatory process were subject to governmental capture rather than capture by the firm, not in the sense that the regulators were pressurised by ministers but that major decisions, in particular the all-important initial price formulae, were determined directly by government to achieve the political objective of successful privatisation." ("Theorizing utility regulation". Ob. cit., p. 204). $\mathrm{O}$ autor esclarece que a identificação dessa circunstância não significa que não haja captura levada a efeito pelos regulados, mas, tão somente, que o fenômeno não pode ser reduzido a essa única hipótese. ("Theorizing utility regulation". Ob. cit., p. 204).
} 


\section{CAPÍtUlO 4: A CARACTERIZAÇÃO DO PROBLEMA DA CAPTURA COMO RISCO DECORRENTE DA REGULAÇÃO}

\subsection{O exercício de regulação na sociedade complexa}

Tal como destacado no primeiro capítulo, a moderna regulação emerge em meados do século XIX. Ao longo do século XX, caminhou-se a passos largos em direção ao aumento paulatino de intervenção do Estado no âmbito econômico, com vistas não só a suprir as denominadas falhas de mercado, mas também a prestigiar interesses sociais atrelados a determinadas atividades econômicas reputadas essenciais (as denominadas public utilities ou os chamados serviços públicos econômicos).

Nesse contexto, o problema da captura das agências reguladoras pode ser examinado sob três enfoques. Primeiro, pode ser reconduzido a uma questão interna ao próprio direito resumida na clássica expressão “quem guarda os guardiães?”. ${ }^{288}$ Em segundo lugar, pode ser analisado como sintoma das dificuldades inerentes ao exercício da regulação pelo Estado Intervencionista. Depois, e especialmente no contexto europeu e brasileiro, a criação das agências reguladoras pode ser vista como uma reação às dificuldades relacionadas ao exercício da regulação. E, então, a captura emerge como uma "externalidade" 289 desse novo instrumento para o exercício da regulação.

Examinar-se-á cada um desses pontos nos itens a seguir.

\subsubsection{O problema da captura como expressão do dilema "Quem guarda os guardiães?"}

GUNTHER TEUBNER faz referência ao paradoxo subjacente à indagação “Quem guarda os guardiães?” para exemplificar a circularidade do sistema jurídico e a necessidade se apreendê-la para tentar evitar o paradoxo que deriva da autorreferência que

\footnotetext{
288 A frase "Quis custodiet ipsos Custodes?" é de JUVENAL, em Satura VI, 1. 347-348. Disponível em: http://www.thelatinlibrary.com/juvenal/6.shtml. Último acesso em: 10.05.2009.

${ }^{289}$ Empresta-se, aqui, o vocabulário da ciência econômica, para a qual externalidades são compreendidas como "efeitos (positivos ou negativos) de uma determinada ação sobre terceiros não-diretamente responsáveis por esta ação.” (ELIZABETH MARIA MERCIER QUERIDO FARINA, PAULO FURQUIM DE AZEVEDO e MARIA SYlvia MACChIONE SAES. Competitividade: mercado, Estado e organizações. Ob. cit., p. 284). Em resumo: trata-se de um efeito não-querido, mas que decorre da tomada de uma decisão.
} 
caracteriza o direito. ${ }^{290}$ Essa circularidade, manifestada na indagação acima referida, é um problema inerente à própria realidade social e, também, ao sistema jurídico. ${ }^{291}$

Em que medida, então, o problema da captura se relaciona com este paradoxo?

As agências reguladoras independentes são criadas para regular determinado setor econômico. Por meio de sua atuação, buscam alterar o comportamento dos agentes econômicos, a fim de compatibilizá-los com a necessidade de que determinadas atividades sejam desenvolvidas e disponibilizadas ao público em geral. Assim, ainda que em uma acepção fraca, a atuação das agências reguladoras implica exercício de algum controle (por meio de regulamentação e fiscalização) sobre os agentes econômicos. ${ }^{292}$ Sob esse ângulo, portanto, é possível afirmar que as agências reguladoras independentes são criadas para exercer controle sobre as atividades reguladas.

Em termos típicos ideais, e tal como exposto no primeiro capítulo, a independência das agências reguladoras decorre, dentro outros fatores, da necessidade de submeter certos setores econômicos a uma regulação primordialmente técnica. Para que esse intento possa ser alcançado, é necessário afastar as agências reguladoras da política partidária, não a subordinando à Administração Central. Diante da ausência desses controles ordinários, permite-se que a pergunta “quem controla os controladores?" dirija-se às agências reguladoras independentes.

Com efeito, quando do surgimento das agências reguladoras independentes nos EUA (e, especialmente, com a criação de novas agências no bojo do New Deal) tinhase que essa era a melhor a configuração para essas estruturas administrativas: atribuição de considerável discricionariedade conjugada com a ausência de controles ordinários. Ocorre que, nesse contexto, é possível identificar a ocorrência de captura. Tal como afirma MARTIN SHAPIRO, "So perhaps is was wrong to allow the technocrats in the agencies wide

${ }^{290}$ O direito como sistema autopoiético. Trad. de José Engrácia Antunes. Lisboa: Fundação Calouste Gulbenkian, 1989, p. 9-10. A obra de TEUBNER tem por finalidade desenvolver uma das três estratégias disponíveis para gerir os paradoxos da auto-referência no direito. ( $O$ direito como sistema autopoiético, Ob. cit., p. 1-21)

${ }^{291}$ Nesse sentido, GUNTHER TEUBNER, apoiado em NIKLAS LUHMANN (O direito como sistema autopoiético, Ob. cit., p. 21). De toda a forma, TEUBNER, embora não acolha, também faz referência a autores que compreendem o problema da auto-referência do direito como um problema de "paradoxos do pensamento jurídico" e não como um problema de "paradoxo do próprio direito" ( $O$ direito como sistema autopoiético, Ob. cit., p. 16 e ss).

292 Aqui, faz-se referência ao entendimento de FÁBIO KONDER COMPARATO, O poder de controle na sociedade anônima, Ob. cit., p. 28-29, exposto no item 2.3.3., acima. 
discretion. They might be captured and use their discretion to serve the regulated industry rather than the public."293

Nesse sentido, o problema da captura emerge como um efeito da questão relacionada ao controle dos responsáveis pelo exercício de funções públicas que não se sujeitam a uma revisão superior e não se subordinam a vínculos de legitimidade popular. ${ }^{294}$

No que se refere especificamente às agências reguladoras independentes, a solução "natural” foi submetê-las ao controle pelo Poder Judiciário. Porém, essa submissão não resolve o problema em definitivo.

Conforme narra MARTIN SHAPIRO, desde o início da década de 1960, assistiu-se a um movimento de intensificação desse controle jurisdicional. Primeiro, o Judiciário passou a exigir que os procedimentos de elaboração de normas constituíssem um processo escrito ("rule-making record"). Depois, passa a adotar a "hard look doctrine" e, por fim, passa a exigir que a regra resultante do processo tenha derivado de um "reasoned decision making" ${ }^{295}$ Essa alteração de exigências é acompanhada pela consideração de questões pertinentes ao conteúdo da regulação. Se, em um primeiro momento, cabia à agência conciliar os interesses em jogo ao elaborar a norma; posteriormente, passa-se a exigir da agência reguladora a apresentação da melhor solução para o tema (exceção feita aos casos de "frontiers of science", em que determinadas circunstâncias não podiam ser conhecidas com suficiente grau de certeza).

\footnotetext{
${ }^{293}$ Who guards the Guardians? Judicial Control of Administration. Athens and London: The University of Georgia Press, 1988, p. 66. Note-se que MARTIN SHAPIRO sequer faz referência à captura como resultado de comportamentos estratégicos dos reguladores com vistas à obtenção de um benefício futuro. Diversamente, $o$ AUTOR concebe que, além do ciclo de vida das agências reguladoras (que, a rigor, o autor não inclui como forma de captura), o problema da captura pode ter origem em três pontos fundamentais: a) o fato de os grupos regulados terem interesse mais direto no resultado da regulação (o que os incentiva a tentarem influenciar, de modo mais intenso, o resultado da regulação); b) o contacto direto entre reguladores e regulados, que pode gerar uma identificação entre os responsáveis pelo exercício da regulação e a indústria regulada (quanto a esse argumento, M. SHAPIRO admite ser um argumento de "psicologia social" e não de ciência política); e c) a regulação pressupõe que as atividades sejam desenvolvidas por empresas privadas e que investimentos sejam por elas realizados (e se é assim, uma das preocupações das agências reguladoras tem de ser, mesmo, a manutenção das empresas sujeitas à regulação). (Who guards the Guardians? Ob. cit., p. 65-66). Quanto a esse último aspecto, M. SHAPIRO não identifica se a captura decorre diretamente desse fato (na medida em que a agência reguladora deve se preocupar com a solidez das empresas responsáveis pelo exercício da regulação, edita normas favoráveis ao setor e tal circunstância implica, ipso facto, captura) ou se é circunstância que apenas favorece a ocorrência da captura (se a agência precisa, sob algum aspecto, proteger a atividade desempenhada pelas empresas sujeitas à regulação, tende a adotar posturas que lhes sejam mais favoráveis, o que pode facilitar a ocorrência do problema).

${ }^{294}$ Além das agências reguladoras independentes, o Poder Judiciário é reconduzido ao mesmo paradoxo. A respeito, ver MAURO CAPPELLETTI, "Who watches the Watchmen? A comparative study on judicial responsaibility". American Journal of Comparative Law. vol. 83 (1), p. 1-62.

${ }^{295}$ Who guards the Guardians?, Ob. cit., p. 48-49.
} 
Ocorre que, paulatinamente, a regulação se torna tecnicamente mais complexa e a verificação da "correção" da regulação pelo Judiciário já não pode mais prescindir da contribuição dos técnicos. O dilema de tal constatação está em que "it makes little difference whether one sees the agency experts as 'on tap' as advisors or 'on top' among the deliberators". ${ }^{296}$ Afinal, a decisão, ela mesma, dependerá da consideração técnica. Quando esse dado é compreendido, assiste-se a um retorno ao prestígio das soluções técnicas elaboradas pelas agências. Na sequência, passa-se a atentar para a circunstância de que, muitas vezes, não é possível encontrar $a$ solução tecnicamente correta. Muitas das questões submetidas à regulação estão sujeitas a incertezas e, em tais ocasiões, o tratamento técnico e científico que se espera das agências não é possível. Ela exercerá nessa ocasião uma escolha pautada em um juízo de prudência. E, então, o problema que se põe é o de que a agência não parece ser a melhor organização para exercer essa função. ${ }^{297}$

Assim, e em termos sucintos, haveria de se distinguir duas situações: a) os casos em que a incerteza pode ser resolvida por meio de proposições técnico-científicas: nessa situação, deve-se atribuir a solução do tema às agências reguladoras, que se sujeitarão a uma revisão mínima do Judiciário; e b) os casos em que as incertezas não podem ser resolvidas por meio do conhecimento técnico-científico e, nessas ocasiões, a única solução possível é o exercício da prudência pelas agências (atribuição que não deveria ser a elas outorgada).

$\mathrm{Na}$ primeira situação, remanescerá a discricionariedade da agência reguladora e, com ela, a questão do controle que sobre ela se exerce. Na segunda, admitese maior controle por parte do Judiciário. Porém, a questão não é solucionada, pois "the only way courts can check on this kind of agency discretion is by themselves engaging in prudential deliberation, that is, exercising discretion. So we now return to looking judicial discretion straight in the face and asking again, Who guards the guardians? And again we will not answer the question in any direct way (...),298

\subsubsection{O problema da captura como sintoma das dificuldades do exercício da regulação em uma sociedade complexa}

\footnotetext{
${ }^{296}$ Who guards the Guardians? Ob. cit., p. 129.

${ }^{297}$ Who guards the Guardians? Ob. cit., p. 142-143.

${ }^{298}$ Who guards the Guardians? Ob. cit., p. 168.
} 
Segundo Helmut WillKe ${ }^{299}$, ao final da Idade Média, vigorava a idéia de que de que o sistema político poderia se fundar em uma autoridade externa: primeiro, na autoridade divina; depois, na autoridade decorrente da própria natureza humana. Posteriormente, no período das Revoluções Burguesas, Deus e Natureza cedem lugar à razão humana. Ocorre que, nesse período (fim do século XVIII e início do século XIX), a sociedade torna-se mais complexa em decorrência da dinâmica da emergente economia industrial e do desenvolvimento da ciência e da tecnologia. A questão que se punha era de se saber "which authority was to contain, control and guide this complexity? Which institution - after God, Nature and Man - was capable of structuring this anomic complexity?",300

Nesse momento, emerge a idéia hegeliana de Estado, como ente capaz de representar toda a sociedade em face das suas parcelas diversificadas. Assim, surge "the State as the sphere of universal altruism". ${ }^{301}$ Em outras palavras, "here it is, the noble hero of the new era, ready to defend the common good, the common identity, the common welfare against the contradictions and contingencies of a civil society which is built in the inherent instability of private interests. $" 302$

A tragédia está em que essa concepção de Estado pode trazer mais problemas do que ela pretende resolver. Dentre elas, e para os fins do presente trabalho, interessa a tragédia de compreender o Estado como um instrumento de solução de problemas sociais e a concepção de Estado Social que daí decorre.

\section{Como afirma WILLKE,}

"The failure seems to be tragic because it builds on the misconception of the State as a general societal problem solver. In this role, the modern State necessarily must become overburdened, it must assume responsabilities it cannot bear, it must elicit hopes it cannot fulfill. In highly developed functionally differentiated societies, there is no single hierarquical top instance or central institution which can adequately represent the complexity of the whole of society, or which would be able to build up the requisite variety (internal complexity) for overall societal problem solving., 303

\footnotetext{
299 "The Tragedy of the State. Prolegomena to a Theory of the State in Polycentric Society". O texto foi originalmente publicado em Archiv für Rechts-und Sozialphilosophie, Bd.72, Nr.4, 1986, S. 455-467. A versão consultada para o desenvolvimento desse trabalho está disponível em: http://www.unibielefeld.de/soz/globalgov//Lit/Willke Tragedy_State.pdf.Último acesso em: 8.5.2009.

300 "The Tragedy of the State", cit., p. 3.

301 "The Tragedy of the State", cit., p. 4.

302 "The Tragedy of the State", cit., p. 4.

303 "The Tragedy of the State", cit., p. 8-9.
} 
Tal como já detectava em meados do século XIX, a sociedade é composta por grupos sociais diferenciados (diversificação essa que se amplia de modo exponencial ao longo do século $\mathrm{XX}$ ). Na medida em que o Estado tem a pretensão (e anuncia a pretensão) de resolver os problemas sociais, esses grupos diversificados passam a demandar a atuação (rápida, precisa e eficiente) do Estado para a solução de questões de naturezas absolutamente diversas. Ocorre que o atendimento prestacional exigido do Estado é missão de difícil (senão impossível) execução. Por um lado, a tarefa tem um indissociável viés econômico: prestar adequadamente serviços públicos demanda, de algum modo, a aplicação de recursos (sejam recursos públicos, sejam recursos de investidores privados, seja eventual contraprestação paga pelos usuários desses serviços).

Contudo, a inversão de recursos nas atividades requeridas é só o passo mais evidente dessa atividade. Ao lado de se ter acesso aos recursos necessários, é preciso identificar onde e em que momento eles devem ser empregados. E, então, surge um novo problema: as atividades demandadas do Estado permeiam diferentes áreas do conhecimento e definir os investimentos necessários requer conhecimento técnico em cada uma delas. Conhecimento técnico e científico que se altera diuturnamente, de modo que a solução ótima de hoje rapidamente se torna obsoleta. Tais exigências, por si, colocam em dúvida a possibilidade de que as demandas dirigidas ao Estado possam ser adequadamente atendidas por meio das estruturas estatais.

\section{Conforme afirma José EDUARDO FARIA, há}

o aumento em progressão geométrica na velocidade do processo de diferenciação sócio-econômica. Cada vez mais os sistemas técnico-científicos, produtivos, financeiros e comerciais se especializam e se subdividem continuamente com base em novas especializações. Ao atuar em áreas crescentemente específicas, eles tendem a produzir suas próprias regras, seus próprios procedimentos, suas próprias racionalidades e suas próprias concepções de justiça. Essa tendência dos diferentes subsistemas à autonomia por sua vez amplia extraordinariamente a complexidade do sistema jurídico. Dificulta o trabalho de produção normativa por parte dos legisladores. E ainda leva toda a legislação por eles editada a ter sua efetividade condicionada à aceitação de suas prescrições justamente pelos distintos sistemas que ela deveria disciplinar, enquadrar, regular e controlar, colocando assim em xeque a própria centralidade dos poderes públicos. ${ }^{304}$

Nesse contexto, ao examinar estritamente essas dificuldades do exercício da regulação, a captura se apresenta como um sintoma do aumento da complexidade social, que cria óbices instransponíveis para o exercício da regulação estatal. ${ }^{305} \mathrm{O}$ problema,

\footnotetext{
304 “As metamorfoses do direito na reestruturação do capitalismo”, p. 1, mimeo.

${ }^{305}$ Nesse ponto, merece referência a crítica desenvolvida por LOUIS L. JAFFE em face do problema da captura: por vezes, a regulação oriunda da agência reguladora e que, posteriormente, é alvo das mais diversas
} 
assim, revela-se como exemplo das questões enfrentadas pelas estruturas estatais para exercer as tarefas a elas atribuídas.

Diante dessa ampliação da complexidade social detectada por JosÉ EDUARDO FARIA, abre-se a possibilidade não só de que as normas regulatórias sejam descumpridas, mas que sejam efetivamente ignoradas (ou, para usar a expressão de TÉRCIO SAMPAIO FERRAZ JR., sejam desconfirmadas). ${ }^{306}$ E esse tipo de reação do destinatário da norma é insuportável para o responsável pela edição da regulação, "pois a desconfirmação equivale ao aniquilamento da autoridade enquanto tal." 307 Assim, diante do "temor" de ver ignoradas as normas por si editadas, torna-se plausível a ocorrência de aproximação entre regulador e regulado (ou entre regulado e poder político), a fim de que o primeiro obtenha "segurança" no desenvolvimento de suas atividades. Ou seja, torna-se plausível a ocorrência da captura na forma detectada pela teoria do ciclo de vida das agências reguladoras. ${ }^{308}$ Nessa medida, o problema da captura é, ao lado de outros fenômenos, mais uma expressão das dificuldades enfrentadas pela regulação estatal em uma sociedade altamente complexa (como a sociedade contemporânea).

Ocorre que, em exame mais amplo, a captura pode ser reconduzida a uma das falhas próprias do exercício da regulação no bojo do Estado Intervencionista. Por ora, deixar-se-ão de lado as necessidades do responsável pelo exercício da regulação, a fim de tentar enfocar o papel do direito e de suas pretensões no exercício da regulação (e o sentido em que é possível tratar do problema da captura nessa seara).

A sociedade contemporânea é funcionalmente diferenciada. Sistemas econômico, político e jurídico exercem funções diferenciadas e desenvolvem interpretações também diversas, a partir da utilização de códigos binários próprios. ${ }^{309} \mathrm{O}$ sistema político exerce uma função que lhe é própria e que permitiu a sua diferenciação funcional em relação aos demais sistemas: trata-se da capacidade de impor decisões vinculantes. ${ }^{310}$ Vinculantes no sentido de que se impõem tanto aos que adotam os referidos

críticas, apoiava-se no conhecimento vigorante no momento de sua edição ("The independent agency - a new scapegoat", cit., passim). A respeito, ver nota 60, acima.

${ }^{306}$ A respeito, ver o tópico 2.2.2, item a,supra.

${ }^{307}$ TÉRCIO SAMPAIO FERRAZ JR., Teoria da norma jurídica, cit., p. 57.

${ }^{308}$ A respeito, ver item 2.1.1., supra.

${ }^{309}$ Sobre o tema, ver item 4.4, infra.

${ }^{310}$ Nas palavras de LUHMANN, "La función que ha provocado la diferenciación del sistema político puede caractarizarse como el empleo de la capacidad de imponer (Parsons: effectiveness) decisiones vinculantes." 
provimentos, como àqueles a quem tais decisões se dirigem. ${ }^{311}$ Por meio dessa função específica, o sistema político oferta prestações em favor dos demais sistemas sociais. Desse modo, quando os demais subsistemas sociais necessitam de decisões vinculantes, eles requerem prestações políticas. ${ }^{312}$ Para que possa exercer a sua função e, também, “(em)prestar” decisões vinculantes aos demais subsistemas sociais, o sistema político dispõe de dois meios essenciais: dinheiro e direito (no sentido de regulamentação de condutas). ${ }^{313}$

No âmbito do Estado de Bem-Estar, os requerimentos de prestações políticas aumentam paulatinamente. Tome-se como exemplo a economia. Se, ao início do século XIX, o sistema econômico se satisfazia com a garantia política do direito privado, com o Estado de Bem-Estar agregam-se novos temas a exigir prestações políticas, tais como a responsabilidade política pelas consequências sociais de certos processos econômicos, o estabelecimento de marcos de garantia política para o funcionamento da economia etc. ${ }^{314}$ Relativamente à regulação econômica, tem-se a atuação do sistema político que, ao empregar um dos instrumentos que tem à disposição (o direito $e$ a respectiva regulamentação de condutas), emite decisões vinculantes com vistas a alterar o modo de funcionamento do sistema econômico.

A questão está em que o sistema econômico também é dotado de autonomia. Decisões vinculantes que se valem do direito não são "apenas" aceitas e incorporadas pacificamente pelo sistema econômico. São, antes, filtradas por seus mecanismos próprios de atuação, de forma que podem não produzir os efeitos que o sistema político pretende gerar. Tal como alerta LUHMANN, "Respecto al derecho, la actual juridificación de muchos ámbitos de la vida ha suscitado uma creciente atención. Así, el problema no sólo reside en la cantidad de regulaciones, que genera sus propios problemas de conocimiento y aplicación, sino también em la cuestión relativa a los limites de lo que sea posible realizar

(Teoría política en el Estado de Bienestar. Trad. de Fernando Vallespín, Madrid: Alianza Editorial, 1997, p. 94)

${ }_{311}^{31}$ NiKLas LuHMANn, Teoría política en el Estado de Bienestar. Ob. cit., p. 94.

312 Textualmente, NIKLAS LUHMANN afirma que "Las prestaciones políticas existen cuando quiera que en otros sistemas fucionales de la sociedad se requieran decisiones vinculantes" (Teoría política en el Estado de Bienestar. Ob. cit., p. 95). Como exemplo, LuhMANN destaca que, ao início do século XIX, já se pôs de forma clara na relação entre política e economia que seria necessária a garantia do direito privado; de mesma forma, na relação entre política e educação, requereu-se a imposição política do ensino obrigatório e a organização de um sistema educacional básico e superior (Teoría política en el Estado de Bienestar. Ob. cit., p. 95$)$.

${ }_{313}^{31}$ Teoría política en el Estado de Bienestar. Ob. cit., p. 104-105.

${ }^{314}$ Teoría política en el Estado de Bienestar. Ob. cit., p. 95. 
por médios jurídicos."

Assim, a utilização do direito pelo sistema político submete-se a um trilema regulatório.

Primeiro, é possível que haja uma incongruência entre direito, sistema político e sociedade ("incongruence" of law, politics and society). Em tal situação, a ação regulatória é incompatível com o modo de interagir do sistema social que se busca regular. Em tal ocasião, o sistema regulado reage por meio de uma não-reação. O direito é inefetivo e não produz mudanças de comportamento. ${ }^{316}$ Em outras palavras: o sistema regulado não considera a regulação que sobre ele se exerce.

Depois, é possível que haja uma sobrelegalização da sociedade (overlegalisation of society). Nessa situação, a ação regulatória influencia tão fortemente o sistema social que visa regular, que acaba por "destruir" a racionalidade do sistema regulado. Nesse sentido, "Law as a medium of the welfare state works efficiently, but at the price of destroying the reproduction of traditional patterns of social life". 317

Por fim, é possível haver uma sobresocialização do direito (oversocialization of law). Aqui, em vez de o direito causar a destruição dos mecanismos internos dos sistemas regualados, são os sistemas regulados que prejudicam o bom funcionamento do direito. Quando isso ocorre, "The law is 'captured' by politics or by the regulated sub-system, the law is 'politicized', 'economized', 'pedagogized' etc. with the result that the self-production of its normative elements gets overstrained." $" 318$

É possível, assim, que o direito perca sua autonomia e, nesse sentido, seja colonizado pelos sistemas político ou econômico. Ao se examinar a realidade mais estrita do exercício da regulação econômica, o problema da captura (em uma situação extremada) pode ser reconduzido a esse problema mais amplo. Em ambas as situações, identifica-se o aniquilamento da autonomia (seja do regulador, seja do sistema jurídico), que passa a atuar a partir de uma lógica que não lhe é própria. Note-se que ambos os problemas podem ser

\footnotetext{
${ }^{315}$ Teoría política en el Estado de Bienestar. Ob. cit., p. 106-107.

${ }^{316}$ GUNTHER TEUBNER, "After legal instrumentalism? Strategic models of post-regulatory law". In: SCOTT, Colin (Ed.). Regulation. The International Library of Essays in Law \& Legal Theory. Aldershot: Ashgate, 2003 , p. 60.

317 GUNTHER TEUBNER, "After legal instrumentalism? Strategic models of post-regulatory law". Ob. cit., p. 61.

${ }^{318}$ GUNTHER TEUBNER, "After legal instrumentalism? Strategic models of post-regulatory law". Ob. cit., p. 61.
} 
reconduzidos ao desgaste da utilização do direito como instrumento de atuação do Estado de Bem Estar. Nele, acaba-se por exigir da regulação e do sistema jurídico a obtenção de resultados que eles não são capazes de produzir. E tal exigência pode lhes custar a sua própria autonomia. ${ }^{319}$

\title{
4.1.3. A criação de agências reguladoras como reação às dificuldades relacionadas ao exercício da regulação estatal
}

Em que pese o problema da captura poder ser interpretado como expressão de problemas de controle (internos ao sistema jurídico) e de funcionamento do Estado Intervencionista, essa identificação não esgota todas as possibilidades de análise.

Assim, e indo adiante, é necessário se ter em conta que a criação de agências reguladoras independentes - especialmente na realidade brasileira e europeia - surge no contexto da crise do Estado Intervencionista e como um dos instrumentos utilizados para se tentar superá-la. Nesses países, a criação das agências reguladoras independentes acompanha os movimentos de liberalização, desestatização e desregulamentação (portanto, os movimentos de reação à crise do Estado de Bem-Estar). ${ }^{320}$

\section{Como bem sintetiza AlKeTA PeCI,}

\begin{abstract}
A crise fiscal do setor público, as inovações tecnológicas e outros fatores importantes estão fazendo com que se abra espaço para uma maior participação do setor privado nesses segmentos, anteriormente considerados de exclusiva atuação do Estado. Medidas em favor da desregulamentação e desestatização têm feito parte das principais políticas governamentais nos últimos anos. Com o estabelecimento dessas novas relações entre o setor público e o privado, prevalece a necessidade de estabelecer novas regulações, capazes de eliminar o risco de conversão de monopólios estatais em monopólios privados, favorecendo o princípio da livre concorrência e protegendo o cidadão-usuário destes serviços.
\end{abstract}

\footnotetext{
${ }^{319}$ Como afirma Teubner, "Overstrain of the law in the welfare state may be the effect of its political instrumentalisation (Luhmann, 1984a), but it may also result from the law's 'surrender' to other sub-systems of society at the cost of its own reproduction (Nonet \& Selznick, 1978, p. 76)." ("After legal instrumentalism? Strategic models of post-regulatory law”. Ob. cit., p. 61)

${ }^{320}$ É nítida a influência do modelo norte-americano de agências reguladoras na elaboração das novas estratégias de atuação do Estado sobre o domínio econômico. Sobre o tema, ver CONRAD HÜBNER MENDES, "Reforma do Estado e agências reguladoras: estabelecendo os parâmetros de discussão". Direito Administrativo Econômico. São Paulo: Malheiros, 2002, p. 109; EdSON NunES, Agências Reguladoras e reformas de Estado no Brasil. Ob. cit., p. 20 e ss., LEILA CUÉLLAR, As agências reguladoras e seu poder normativo. Ob. cit., p. 65-75; MARÇAL JUSTEN FILHO, O Direito das Agências Reguladoras Independentes. Ob. cit., p. 52-54. Nesse sentido, EGON BOCKMANN MOREIRA chega a afirmar que "A disseminação mundial das agências reguladoras (com os mais diversos nomes, mas com a mesma rationale) deu consistência à chamada 'americanização do direito' - fenômeno através do qual os ordenamentos nacionais vão se tornando semelhantes, ao menos em alguns pontos, ao direito norte-americano." ("Os limites à competência normativa das agências reguladoras". In: ARAGÃO, Alexandre Santos de. O poder normativo das agências reguladoras. Rio de Janeiro: Forense, 2006, p. 192).
} 
Por outro lado, a simples passagem às mãos do setor privado não garante uma melhor prestação de serviços públicos. A criação das agências reguladoras pode ser considerada um passo importante no fortalecimento do novo marco regulatório, na medida que sua função é regular o funcionamento de determinados setores de economia ou serviços públicos concedidos pelo Estado. ${ }^{321}$

Desse modo, poder-se-ia afirmar que as alterações inerentes ao exercício da regulação que inspiraram a criação de agências reguladoras independentes no contexto europeu e brasileiro derivam do fato de que " the actual practices of government agencies were necessarily so many, so complex and so varied, they could not be governed by a single, simple set of uniform rules." 322

Todavia, a questão não parece se resumir a esse dado. Se é certo que o exercício de regulação impõe dificuldades, essa não é questão exclusiva do mais recente movimento de criação de agências reguladoras independentes. ${ }^{323}$ Diversamente, isso remonta às dificuldades de se exercer a regulação em um Estado Intervencionista, nos moldes examinados em passagem anterior. ${ }^{324}$ Para essa parcela do trabalho, o que parece mais fundamental é o fato de que, quando adotadas ao final do século $\mathrm{XX}$, as agências reguladoras passam a ser expressão da atual configuração da sociedade.

É certo que, em período anterior aos movimentos de liberalização, privatização e desestatização, países europeus e latino-americanos não deixavam de regular as atividades desenvolvidas pela iniciativa privada. Ocorre, no entanto, que ela era exercida por meio do Estado, organizado de modo fechado e hierarquizado. Por óbvio, havia regulação setorial. ${ }^{325}$ Porém, os vínculos de subordinação jurídica mantinham certa coesão entre os organismos responsáveis pela regulação (ao menos em sentido formal). ${ }^{326}$

Com a superveniência de tais movimentos, ocorre uma fragmentação da regulação estatal. Nela, à margem do aparelho administrativo, a regulação passa a ser exercida por organismos dotados de autonomia e liberdade de atuação, que escapam da estrutura hierárquica do Estado, em um movimento de autonomização da regulação em

\footnotetext{
${ }^{321}$ Novo marco regulatório para o Brasil pós-privatização: o papel das agências reguladoras em questão. Trabalho apresentado no Encontro Anual da Associação Nacional de Pós-Graduação e Pesquisa em Administração - ENANPAD. 1999, Disponível em: http://www.anpad.org.br/enanpad/1999/dwn lenanpad1999-ap-13.pdf. Último acesso em 08.05.2009.

${ }_{322}$ MARTIN SHAPIRO, Who guards the Guardians? Ob. cit., p. 39.

${ }^{323}$ Prova disso é o trecho da obra de MARTIN SHAPIRO mencionado no parágrafo anterior. O texto de faz referência a argumentos invocados em meados da década de 40 quanto à implementação das políticas do New Deal.

${ }^{324}$ Ver item 4.1.2., acima.

${ }^{325}$ Sobre a pré-existência de órgãos setoriais no Brasil, ver item 3.1, supra.

326 JACQUES CHEVALLIER, "La régulation juridique en question". Droit et Societé. vol. 49, 2001, p. 838.
} 
relação ao Estado. ${ }^{327}$ E, nesse sentido, "Tout se passe donc comme si le modèle unitaire était en voie d'être mis en cause au profit d'un modele nouveau, de type 'polycentrique", 328

A criação de agências reguladoras independentes nesse momento histórico pode ser interpretada como expressão desse policentrismo da regulação contemporânea (e, consequentemente, da redução do espaço de atuação do Estado).

Tal como consigna José EDUARDO FARIA, contemporaneamente, o direito positivo passa a se confrontar com intensas limitações estruturais. Uma delas é, justamente, o fato de que "as formas tradicionais e excessivamente hierarquizadas de ação e regulação públicas se tornam incompatíveis com a flexibilidade e as possibilidade que as novas tecnologias propiciam, sendo progressivamente substituídas por órgãos dotados de ampla autonomia funcional e administrativa". 329

Daí se poder afirmar que "A insurgência de espaços administrativos efetivamente autônomos frente ao Poder Executivo central, do que as agências reguladoras independentes constituem o exemplo mais relevante em nosso Direito Positivo, é uma exigência de eficaz regulação estatal de uma sociedade também diferenciada e complexa".330

Ao argumento poder-se-ia opor a idéia de que, em verdade, a criação de agências reguladoras independentes tem origem em decisões estatais, de modo que não podem ser tomadas como expressão do policentrismo decisório que caracteriza a sociedade contemporânea.

Todavia, o fato de haver decisão por parte do Estado não parece afastar a conclusão aqui sustentada.

\footnotetext{
${ }^{327}$ JACQUES CHEVALLIER, "La régulation juridique en question". Ob. cit., p. 838-839. O neologismo referido no texto é retirado da afirmação de Chevallier, no sentido de que "la fonction de régulation tend ainsi progressivement à s'autonomiser dans l'État" (Ob. cit., p. 839)

328 JACQUES CHEVALlier, "Régulation et polycentrisme dans l'administration française" La Revue Administrative. vol. 301, Paris, 1998, p. 44.

${ }^{329}$ Direito e conjuntura, Ob. cit., p. 36. Embora o autor não aponte expressamente, a indicação das características mais marcantes das agências reguladoras independentes permite supor que esteja a fazer referência a essas organizações. Por sua vez, J. CHEVALLIER expressamente menciona o surgimento das agências reguladoras independentes como exemplo do policentrismo decisório que se instala na sociedade atual. ("Régulation et polycentrisme dans l'administration française", Ob. cit., p. 44-45)

330 AleXandRe Santos De ARAGÃo. Agências reguladoras e a evolução do Direito Administrativo Econômico. Ob. cit., p. 218-219 (original sem destaque).
} 
Por certo, a criação de agências reguladoras independentes não esgota todas as alterações pelas quais perpassa a atuação do Estado na sociedade complexa. ${ }^{331}$ Aliás, tal pode ser interpretada como um dos exemplos mais tímidos de alteração do modo de produção do direito na sociedade atual. ${ }^{332}$ Porém, não se pode olvidar que a criação de agências tem origem em movimentos mais amplos, que perpassaram a maioria dos países ocidentais. Desse modo, a alteração da estratégia de atuação em face do domínio econômico parece estar mais ligada a essa circunstâncias (e menos vinculada a uma "consciente" tomada de posição do Estado no sentido de alterar o modo como passará a exercer a regulação).

\title{
Nas palavras de J. CHEVALLIER,
}

\begin{abstract}
“Ce processus d'éclatement reste à première vue canalisé et contrôlé par l'État: c'est l'État qui accepte de renoncer à certaines prérogatives de souveraineté au profit d'organisations internationales; c'est à son initiative que certaines attributions vont se trouver déléguées à des entités autonomes; c'est toujours lui qui décide de créer en son sein des autorités de régulation indépendantes. (...) Néanmoins, cette maîtrise est plus apparente que réelle: la diffusion de la fonction de régulation est devantage le produit de constraintes objectives, que l'expression d'une stratégie délibérée de l'État; et cette autonomisation réduit d'autant la capacité de régulation étatique." ${ }^{333}$
\end{abstract}

\footnotetext{
${ }^{331}$ Isso é reconhecido por ALEXANDRE SANTOS DE ARAGÃo, Agências Reguladoras e a evolução do direito administrativo econômico. Ob. cit., p. 216.

${ }^{332}$ Especialmente se comparada com os meios de produção do direito que se desprendem por completo do ente estatal. Nesse sentido, ver, por exemplo, GUNTHER TEUBNER ("The corporate codes of multinationals: company constitutions beyond corporate governance and co-determination". In: NICKEL, Rainer (ed.). Conflict of Laws and Laws of Conflict in Europe and Beyond: Patterns of Supranational and Transnational Juridification, Oxford: Hart, 2009. Disponível em: http://www.jura.uni-frankfurt.de/ifawz1/teubner /dokumente/CorporateCodes eng.pdf. Último acesso em: 8.5.2009). Por outro lado, é possível afirmar que, diante de sistemas de dupla jurisdição (tal como os europeus), o surgimento de agências reguladoras como ente que se coloca ao lado da estrutura administrativa tradicional torna-se mais clara. Na medida em que os sistemas de dupla jurisdição foram concebidos para evitar o controle de atos administrativos pela Justiça Comum, tem-se que os atos administrativos "circulam" somente no âmbito da Administração (mesmo quando submetidos a controle, esse é exercido, em última ratio, pela jurisdição administrativa, que também integra a Administração). Quando surgem as agências reguladoras, elas não se coadunam com essa estrutura fechada, colocando-se ao lado dela (sobre a relevância da idéia de unidade para a organização da Administração Pública Francesa, ver JACQUES CHEVALLIER "Régulation et polycentrisme dans l'administration française." Ob. cit., p. 43). Aliás, há quem diga que o surgimento das agências reguladoras independentes presta-se a suprir algumas das deficiências de funcionamento do sistema da Justiça Administrativa (JEAN-LOUIS AUTIN. "Du juge administratif aux autorités administratives indépendantes: un autre mode de régulation". Revue du Droit Public et de la Science Politique em France et a L'Étranger. vol. 5, Paris, 1988, p. 1218). Em países como o Brasil, sujeitos à jurisdição una, o controle jurisdicional, sob certo ângulo, já mitiga esse completo fechamento da estrutura administrativa. De toda a sorte, e examinando-se exclusivamente a estrutura da Administração, tem-se que as agências reguladoras produzem efeito similar ao identificado nos países europeus. Os instrumentos de "fechamento" da estrutura administrativa e que permitiam a subordinação das agências ao chefe da Administração Pública (recurso administrativo hierárquico e tutela) não mais se aplicam, de modo que essas estruturas acabam por se colocar ao lado da estrutura administrativa tradicional.

${ }^{333}$ JACQUES CHEVALLIER, "La régulation juridique em question”. Ob. cit., p. 840.
} 
Nessa medida, o problema da captura das agências reguladoras pode se colocar. Parece possível afirmar que ele acompanha a utilização agências reguladoras para o exercício da regulação como uma "externalidade" decorrente da utilização do modelo das agências. ${ }^{334}$

E isso porque a criação de diferentes centros decisórios altamente especializados só é possível mediante a atribuição de ampla discricionariedade aos responsáveis pela edição da regulação (tal como ocorre com as leis-quadro de constituição das agências reguladoras independentes). ${ }^{335}$ Essa ampla discricionariedade unida à tecnicidade dos temas sujeitos à regulação e à constante mutação (não só dos fatos, mas também do conhecimento técnico-científico) criam as condições para que apareça o slack, espaço de liberdade em que a captura do responsável pelo exercício da regulação pode ocorrer.

Mas não é só. Tal como consigna José EduARDo FARIA, o Estado, ao perceber que não pode controlar produzir e dominar o direito de modo universal e incontrastável, adota algumas medidas pragmáticas. Dentre essas reações, está a procedimentalização do direito, por meio da qual "o Estado deixa de decidir o conteúdo das leis, limitando-se a estabelecer procedimentos para que os diferentes setores sociais possam negociar as alternativas mais adequadas aos seus respectivos interesses". 336

A criação de agências reguladoras independentes pode ser vista como expressão dessa tendência de procedimentalização. A criação de normas regulatórias por meio de agências independentes normalmente se dá no bojo de um processo administrativo, por meio da intervenção dos diversos interessados.

Se, por um lado, as normas derivadas dessa procedimentalização da regulação podem ser interpretadas como resultado da ampliação da participação popular

\footnotetext{
${ }^{334}$ A respeito, ver nota 289, supra.

${ }^{335}$ A título ilustrativo, confira-se a afirmação de CARLOS ARI SUNDFELD sobre o modelo regulatório de telecomunicações: "Essa característica do quadro legal - a de flexibilizar a gerência da própria estrutura jurídica das telecomunicações - foi imaginada para, em primeiro lugar, permitir a absorção, sem necessidade de constante revisão do próprio modelo, das rápidas e profundas mudanças por que vem passando o campo das telecomunicações - e cuja direção ou dimensão não é possível, hoje, prever. Em suma, trata-se de um modelo camaleão, aberto, adaptável às situações e a seu câmbio." ("A regulação das telecomunicações: papel atual e tendências futuras". Revista Diálogo Jurídico. Salvador, vol. I, no 3, jul2001. Disponível em: http://www.direitopublico.com.br/pdf 3/DIALOGO-JURIDICO-03-JUNHOCARLOS-ARI-SUNDFELD.pdf. Último acesso em 08.05.2009, original sem grifo).

${ }^{336}$ Direito e conjuntura. Ob. cit., p. 56.
} 
no exercício da regulação ${ }^{337}$; por outro, é inescapável a tendência de que essa participação mais ampla derive dos grupos mais organizados e mais interessados no resultado da regulação. ${ }^{338}$ Por consequência, reúnem-se condições para a ocorrência de captura, não só em decorrência de eventual comportamento estratégico do responsável pelo exercício da regulação, mas especialmente em virtude da assimetria informacional que aí se estabelece. $^{339}$

\subsection{Problema da captura: característica inerente à regulação?}

A identificação do problema da captura levada a efeito nos capítulos anteriores detectou circunstâncias que permitem a ocorrência do problema. Por um lado, indicou que a "busca de segurança" por parte dos regulados pode fazer com que se aproximem dos grupos regulados ou, mesmo, da política partidária. Por outro, examinou o fato de que a discricionariedade outorgada ao regulador pode permitir o surgimento de um "espaço de liberdade" deixado ao regulador sem a devida sujeição ao escrutínio público e que tal circunstância poderia favorecer a ocorrência de captura. Por fim, ao tempo em que se identificou a possibilidade de que as agências sejam desautorizadas e os diferentes tipos de controle que incidem nas relações entre regulador-regulado, detectou-se que a captura pode decorrer da inevitável assimetria informacional entre reguladores e regulados.

Ao longo deste capítulo, detectou-se que o problema da captura pode ser interpretado como $(i)$ resultado de problemas de controle (inerentes ao próprio sistema jurídico); (ii) sintoma das dificuldades de se exercer regulação em um Estado Intervencionista; e (iii) decorrência das medidas adotadas para fazer frente às dificuldades impostas pelo Estado Intervencionista. Entende-se que essas interpretações não são

\footnotetext{
${ }^{337}$ Nesse sentido, PAULO MATTOS, para quem a criação das agências reguladoras independentes implica a ampliação da possibilidade de participação popular no exercício da regulação, especialmente se comparado com a regulação editada por meio da Administração centralizada ("O novo Estado Regulador no Brasil: Direito e Democracia". Tese de Doutorado apresentada à Faculdade de Direito da Universidade de São Paulo. 2004, passim).

${ }^{338}$ Conforme item 2.3., acima.

339 Ver item 2.3.2, acima. Aliás, JOSÉ EDUARDO FARIA vai ainda mais longe ao afirmar que a opção pela procedimentalização faz com que se abdique de decisões unilaterais e imperativas. Segundo o AUTOR, "essa estratégia configuraria uma forma de 'rendição' do poder público, na medida em que, ao beneficiar grupos econômicos, sociais e políticos com poder de voz, capacidade de mobilização e poder de veto, ela conduz à privatização da produção do conteúdo do direito. Graças a essa estratégia, conglomerados empresariais, entidades de classe, órgãos de representação corporativa e organizações não-governamentais podem multiplicar seu poder político, convertendo-o em poder normativo sem precisa obrigatoriamente passar pelos filtros democráticos tradicionais". (Direito e conjuntura. Ob. cit., p. 56-57)
} 
excludentes entre si. Diversamente, todas elas devem ser consideradas e combinadas, com vistas a se obter o contexto em que o problema da captura pode ocorrer.

Sendo assim, uma questão emerge de imediato: se o problema da captura é um problema que acompanha desde as dificuldades internas do próprio direito e faz-se presente nas formas atuais de produção normativa, é possível afirmá-la como um problema inevitável, isto é, como um problema que inoxeravelmente se fará presente quando ocorrer exercício de regulação (especialmente por meio de agências reguladoras independentes)?

A primeira resposta, especialmente quando se considera a plêiade de críticas que são dirigidas à adoção do modelo das agências reguladoras independentes, seria positiva. Afinal, tal como afirma ironicamente JAMES Q. WILSON, "One cannot mention regulatory agencies without adding the observation that, of course, such agencies are likely to be 'captured' by the interests they are supposed to regulate. To suggest that matters are any different from this is to mark oneself as hopelessly naïve or even disingenuous." 340

Todavia, depois do exame aqui empreendido, a resposta não se afigura tão simples. Quando menos, a "obviedade" de que trata o excerto acima não parece tão clara. Desse forma, e assumindo os riscos de se receber os rótulos acima indicados, não se entende possível interpretar a captura como manifestação inafastável do exercício de regulação por meio de agências reguladoras independentes. ${ }^{341}$

Essa resposta tem fundamento em duas ordens de considerações.

A primeira delas envolve as dificuldades próprias de se sujeitar a regulação editada (e, consequentemente, identificar a emergência do problema da captura) à avaliação. Como bem destaca WILSON, em que pesem as virtudes dos modelos econômicos para explicação da existência da regulação (e que, ipso facto, identificariam a ocorrência de captura), permanece sem resposta uma questão: "are the facts consistent with the model?"342-343

\footnotetext{
${ }^{340}$ The politics of regulation. New York: Basic Books, 1980, p. ix (original sem destaque).

${ }^{341} \mathrm{Ou}$, na síntese de Tony Prosser, "Therefore capture cannot be predicted as a matter of a priori principle". ("Theorizing utility regulation". Ob. cit., p. 204).

342 The politics of regulation. Ob. cit., p. 361.

${ }^{343}$ Há, aliás, estudos que demonstram as deficiências presentes nos modelos econômicos neoclássicos (especialmente por deixarem de considerar o arcabouço institucional em que se dá a atuação do regulador). A respeito, consulte-se o trabalho de RONALDO FIANI, “Afinal, a quais interesses serve a regulação?”. Economia e Sociedade. vol. 13, n. 2 (23), jul-dez 2004, p. 81-105.
} 
A dúvida é razoável. Isso porque, embora as agências reguladoras independentes que atuam em relação a indústrias específicas sejam amplamente criticadas por sua aproximação com as indústrias reguladas, há agências independentes (especialmente as de atuação inter-setorial) em que esse dado não é tão evidente. ${ }^{344}$

Assim, resposta à questão demandaria a realização de pesquisa empírica precisa que, a partir de dados objetivos, pudessem evidenciar em que medida os fatos se aproximam (ou se afastam) do modelo. Identificar-se-ia, então, o "produto" da atuação das agências reguladoras (isto é, o teor da regulação por elas editada) e de que modo distribuem custos e benefícios entre empresas reguladas, grupos políticos e o público em geral. ${ }^{345}$ Todavia, e de acordo com PAUL J. QUIRK, a realização de pesquisa empírica de tal teor não é factível. ${ }^{346}$

Primeiro, decisões regulatórias não contrapõem, de forma clara e precisa, interesse público ou geral vs. interesse privado dos grupos regulados. ${ }^{347}$ Normalmente, em cada um dos pólos de uma discussão singularmente considerada fazem-se presentes subgrupos de interessados das mais diferentes índoles. ${ }^{348}$ Segundo QUIRK, essa realidade não pode ser apreendida por uma análise estritamente objetiva (e, nem mesmo, pela aplicação de técnicas analíticas como a avaliação custo $v s$. benefício). ${ }^{349}$

Depois, é extremamente complexo definir o que são benefícios e o que são custos derivados da regulação. Diante do conjunto de objetivos que a regulação pode visar, benefício tanto pode ser o aumento do nível de informações disponibilizadas aos consumidores, como também o melhoramento da qualidade dos serviços, a redução dos

\footnotetext{
${ }^{344}$ Nesse sentido, PAUL J. QUIRK consigna que "there are some agencies (ICC, CAB) that have generally been considered highly responsive to regulated industry, and others (FTC, FDA) about which there would be sharp disagreement on the extent of industry influence" (Industry Influence in Federal Regulatory Agencies. Princeton: Princeton University Press, 1981, p. 9). Ver, ainda, MARTIN SHAPIRO, que explica o modo como se deu o surgimento de novas agências reguladoras independentes (especialmente relacionadas à saúde, à segurança no trabalho e ao meio ambiente) concomitantemente à desconfiança que se tinha em relação aos reguladores (Who guards the guardians? Ob. cit., p. 79 e ss).

${ }^{345}$ Paul J. Quirk, Influence in Federal Regulatory Agencies. Ob. cit., p. 5. O AUTOR não menciona os "grupos políticos". Porém, diante da identificação da possibilidade de que o problema também possa ocorrer sob esse viés, a menção foi aí incluída.

${ }^{346}$ Influence in Federal Regulatory Agencies. Ob. cit., p. 6.

${ }^{347}$ Sobre as dificuldades quanto ao conceito de interesse público e a tentativa de superá-las, ver item 2.2.2.

${ }^{348}$ A respeito, SABINO CASSESE, ao examinar o ângulo dos regulados, detecta haver uma "asimmetrie dei regolati", isto é, nem todos os regulados estão na mesma posição de fato. Assim, o operador histórico, os primeiros entrantes no mercado e os últimos entrantes têm, cada um deles, interesses diversos a defender ("Dalle regole del gioco al gioco com le regole". Mercato concorrenza regole. n. 2, ago-2002, p. 269).

${ }^{349}$ Influence in Federal Regulatory Agencies. Ob. cit., p. 6. Afinal, e como salienta JAMES Q. WILSON, "the behavior [das agências reguladoras] is complex and changing; it cannot easily be summarized as serving the interests of either the regulated sector or the public at large".(The politics of regulation. Ob. cit, p. 373).
} 
preços, a ampliação da segurança dos produtos etc. Por sua vez, custo tanto pode ser preços mais altos, como a redução de lucros, a criação de inconveniências para os consumidores, etc. Além da arbitrariedade inerente à escolha dessas variáveis, seria necessário encontrar padrões de medida que permitissem a comparação entre a atuação das diferentes agências e o funcionamento dos diferentes programas. ${ }^{350}$

Por fim, e ainda que houvesse instrumentos de investigação que permitissem superar as dificuldades acima salientadas (e, ao dizer de QUIRK, não há), há questão que, cabalmente, impede que a referida pesquisa seja realizada. Esse elemento envolve o desconhecimento quanto aos efeitos precisos das decisões regulatórias (ainda que os objetivos possam estar bem definidos). Tal como afirma PAUL J. QUIRK, "Regulation actions have their effects on complex, open-ended systems. It is always problematic whether any estimate has properly controlled for all other significant factors affecting the variables under study". 351

As considerações de QUIRK não só justificam a impossibilidade de se realizar pesquisa empírica objetiva sobre os efeitos da regulação (com vistas a identificar o problema da captura), como também permitem afirmar a impossibilidade de defender que, "obviamente", a atuação das agências reguladoras independentes tem em vista a tutela dos interesses dos grupos regulados. Se o próprio resultado da regulação é contingente (na medida em que o fim buscado pode não ser atingido), torna-se claro que o problema da captura tem igual natureza. Afinal, mesmo que toda e qualquer atuação de agências reguladoras independentes estivesse comprometida de antemão com eventuais grupos de interesse (o que, por si, não é indene de dúvida), nem sempre o resultado visado seria obtido, pois não é possível se conhecer, com precisão e ex ante, o efetivo resultado que será produzido pela regulação.

\footnotetext{
${ }^{350}$ Influence in Federal Regulatory Agencies. Ob. cit., p. 7.

${ }^{351}$ Influence in Federal Regulatory Agencies. Ob. cit., p. 7. Não fosse isso, por vezes, exige-se da agência reguladora independente a obtenção de resultados que, faticamente, são difíceis de serem obtidos. Tal como afirma ROBERT HORWITZ, "Regulatory agencies are also limited by the difficulty of their tasks. Just because an agency is mandated to achieve a certain goal does not mean the attainment of that goal is administratively possible" (The irony of regulatory reform: the deregulation of American telecommunications, New York and Oxford: Oxford University Press, 1989, p. 45). Note-se que mesmo para MARTIN SHAPIRO, autor que considera a hipótese de captura bastante plausível, essa não é a única explicação para o mau funcionamento da regulação. Segundo esse autor, "In some instances, agencies had been captured and their regulations had come to favor the industry against the public. In others, the regulations had been well-intended but turned out to be wrong" (Who guards the guardians? Ob. cit., p. 97).
} 
Indo adiante, a última das considerações de QUIRK - mencionada acima - já introduz a segunda ordem de considerações que impedem a afirmação de que o problema da captura acompanha, de modo inexorável, o exercício de regulação.

Tal como já exposto, a regulação econômica envolve a utilização do direito como meio para alterar o funcionamento do sistema econômico. Porém, o sistema econômico é, ele mesmo, autônomo e funciona a partir de uma lógica própria. Nesse contexto, a regulação pode ser interpretada pelo sistema econômico das mais diversas formas. GUNTHER TEUBNER diferencia seis diferentes leituras que podem ser levadas a efeito pelo sistema econômico ${ }^{352}$ :

1. impossibilidade de leitura: as operações econômicas permanecem indiferentes às normas jurídicas que a elas se dirigem;

2. leitura como property rights: as normas são lidas como alterações de patrimônio e de propriedade. Nesses casos, “as normas não serão concebidas como mandamentos normativos de ação, e sim como genuínas expectativas econômicas do tipo cognitivo (e não normativo)." ${ }^{, 353}$ Assim, as normas oferecem formas de "aprendizado" ao sistema econômico, a fim de que ele possa identificar os limites e as chances que tem para atuar;

3. leitura como registros contábeis no cálculo econômico: as informações não compõem o conjunto de dados que delineiam a ação fática; diversamente, as normas são submetidas a avaliações de custo vs. benefício e, a partir delas, decidese quanto à sua observância (ou não). Nesse cálculo leva-se em conta não só o peso da sanção, mas também a probabilidade de que seja aplicada;

\footnotetext{
352 "Direito regulatório: crônica de uma morte anunciada". Trad. de: Rodrigo Octávio Broglia Mendes. In: TEUBNER, Gunther. Direito, sistema e policontextualidade. Piracicaba: Editora Unimep, 2005, p. 45 e ss.

353 "Direito regulatório: crônica de uma morte anunciada", Ob. cit., p. 46. A referência à diferença entre expectativas normativas e cognitivas remete-se à teoria dos sistemas de LUHMANN. "Expectativas" são estruturas que reduzem a complexidade e permitem que escolhas sejam realizadas. Embora promovam tal redução de complexidade, expectativas sempre estão sujeitas a frustrações. De modo especial, a diferença entre expectativas normativas e expectativas cognitivas reside na forma de tratamento dessas frustrações. Expectativas normativas são aquelas que se mantêm, ainda que contrariamente aos fatos. São, portanto, essencialmente contrafactuais (resistem aos fatos mesmo que tenham sido frustradas). Por sua vez, as expectativas cognitivas são as que se alteram de acordo com os fatos, isto é, tomam os fatos como um dado de aprendizado e a eles se adaptam (a respeito, ver NikLas LuHMAnN, Sociologia do Direito. Vol. I, Rio de Janeiro: Tempo Brasileiro, 1983, p. 45 e ss). Diante disso, nessa leitura específica, as normas jurídicas são interpretadas pelo sistema econômico não como mandamentos normativos, mas como expectativas cognitivas (que "ensinam" os limites de atuação).
} 
4. leitura como moeda de barganha: as normas jurídicas são utilizadas como instrumentos para se atingir outros objetivos; "são reconstruídas como estratégias, isto é, como estruturas econômicas de tipo especial para 'barganhar sob a sombra da lei", ${ }^{\prime 354}$;

5. leitura como modificação de preferência: são as situações em que as normas jurídicas levam à alteração das preferências dos agentes econômicos;

6. leitura no contexto dos programas de auto-regulação: trata-se da identificação de qual programa de regulação será perseguido, concretamente, no campo regulado. A partir de tal identificação e da formulação das estratégias de regulação, verifica-se se a regulação jurídica e a regulação econômica podem (ou não) coincidir. ${ }^{355}$

A possibilidade de identificar essas diferentes leituras permite verificar que as normas jurídicas incidem sobre outros sistemas sociais (tal qual o sistema econômico). Porém, também torna claro que esses outros sistemas, autônomos que são, reconstroem as normas de acordo com o seu respectivo horizonte de sentido. ${ }^{356}$

Nessa medida, duas circunstâncias se colocam de imediato. Por um lado, uma norma jurídica regulatória pode ser lida de diferentes formas pelo sistema econômico (e não se pode precisar, de antemão, qual será a leitura que o sistema autônomo fará). Diante disso, coloca-se a mesma questão acima identificada: não há qualquer garantia de que o fim visado pela regulação (mesmo que seja a suposta tutela de atores econômicos sujeitos a regulação) será efetivamente atingido. Por outro, a imposição de normas por atores econômicos com vistas a atingir outros objetivos é, apenas, uma das leituras possíveis de ser levada a efeito pelo sistema econômico (leitura como moeda de barganha). Ao lado dela, põem-se outras tantas e não é possível se precisar, previamente, qual será privilegiada pelo sistema econômico e em quais circunstâncias.

\footnotetext{
${ }^{354}$ GUNTHER TEUBNER, "Direito regulatório: crônica de uma morte anunciada”, Ob. cit., p. 46.

355 Tal como referido anteriormente, a exposição dessas seis leituras tem por base o texto de GUNTHER TEUBNER, "Direito regulatório: crônica de uma morte anunciada", Ob. cit., p. 45-47. Quanto a essa última leitura, uma advertência terminológica deve ser feita. O significado da expressão "regulação econômica" utilizada ao longo do trabalho e a que se faz referência nessa parcela específica do texto não coincidem. Nessa parcela, e para o excerto permanecer fiel às idéias de G. Teubner, a expressão remete-se a uma manifestação própria do sistema econômico (que se coloca ao lado da regulação jurídica). Ao longo do restante do trabalho, utiliza-se a expressão "regulação econômica" para fazer referência à utilização de instrumentos jurídicos sobre o sistema econômico (portanto, para se remeter à "regulação jurídica" sobre o sistema econômico).

${ }^{356}$ GUNTHER TEUBNER, "Direito regulatório: crônica de uma morte anunciada”, Ob. cit., p. 46.
} 
Pelas razões expostas, parece difícil aceitar que o problema da captura como característica inerente ao exercício da regulação (mormente por meio de agências reguladoras). Nesse sentido, entende-se que as teorias que identificam o problema da captura, menos que conceder explicações positivas satisfatórias para fenômenos como a existência de regulação econômica exercida por meio de agências reguladoras (ou, mesmo, para o modo de funcionamento dessas organizações), elas têm a virtude de chamar a atenção para um problema: em virtude das características dos entes reguladores e diante das atividades por eles desenvolvidas, é possível que, em vez de atuar de modo imparcial, a agência passe a funcionar como tutora dos interesses regulados ou dos interesses de determinados grupos. O problema é mais amplo que a mera existência de eventual ato regulatório que favoreça um determinado grupo (que, aliás, pode ser genuinamente fruto de escorreita atuação por parte da agência). Envolve, em verdade, a motivação pessoal daqueles que exercem regulação (que podem pretender tutelar interesses pessoais ou buscar zonas de segurança para o exercício das atividades regulatórias) e a presença de eventuais distorções institucionais (a assimetria de informações em desfavor do regulador).

Está-se, assim, diante de uma possibilidade, sendo impossível afirmar, de antemão ou de modo abstrato, a presença ou a ausência do fenômeno da captura.

\subsection{A caracterização do problema da captura como um risco}

\subsubsection{Pressuposto teórico: teoria dos sistemas}

No desenvolvimento do presente trabalho, ter-se-á por pressuposto a ideia de "risco" e "perigo" desenvolvida por NiKLAS LuHMANN e de que modo tais temas podem ser tratados pelo sistema social, tomando-se especialmente o papel do sistema jurídico. ${ }^{357}$

\subsubsection{O conceito de risco de LUHMANN}

Depois de indicar que a sociologia carece de um conceito científico de "risco", LuHMANN dedica-se a tentar identificar de que modo tal fenômeno poderia ser

\footnotetext{
${ }^{357}$ Sociologia del rischio. Trad. de: Giancarlo Corsi, Torino e Milano: Bruno Mondadori, 1996. Em que pese haver outras matrizes teóricas que poderiam ser utilizadas para explicar o fenômeno do risco (por todos, UlbRICH BeCK, La sociedade del riesgo global. Trad. de Jesús Alborés Rey. Madrid: Siglo Veintiuno de España editores, 2002), optou-se por utilizar a teoria luhmaniana por se entender que o recurso explicativo que se obtém a partir dela é mais condizente com os propósitos deste trabalho. Como se verá na sequência, a noção de risco na teoria de Luhmann não se limita a indicá-lo como uma característica generalizada da sociedade contemporânea, mas permite que se o vincule à tomada de uma decisão. Nesse sentido, facilita a compreensão do fenômeno e de seu respectivo "tratamento".
} 
conceituado.

Antes da aproximação ao conceito de risco de LuHMANN, há de se destacar que, relativamente às observações de segundo grau (observações das observações), LUHMANN diferencia objetos e conceitos. Segundo ele, objeto significa indicar (portanto, diferenciar) algo de todo o restante, sem ter em conta o outro lado da distinção. Por sua vez, conceito leva em consideração o outro lado da distinção (homem/mulher, frio/quente etc.). As condensações dessa prática discriminante - que leva em conta o outro lado da distinção - são denominadas conceitos. ${ }^{358}$

Ainda antes da indicação do conceito de "risco", duas outras considerações precisam ser feitas. ${ }^{359}$ A primeira é a de que a idéia de risco envolve um fenômeno de múltiplas contingências. A segunda (intimamente relacionada com a primeira) é a circunstância de que, do ponto de vista do presente, o futuro é inseguro (ou, na síntese de CELSO FERNANDES CAMPILONGO, “não se conhece o futuro na véspera”360).

Tendo em conta esses pressupostos, o conceito de "risco" vincula-se à ideia de que o futuro depende de decisões adotadas no presente. Passa a ser possível falar em risco quando é possível tomar uma decisão sem a qual não seria possível surgir um dano. ${ }^{361}$ Para o conceito, ainda é relevante a idéia de que os danos contingentes são causados de modo contingente (isto é, os danos em questão foram produzidos de tal modo que podiam ser evitados - se outra tivesse sido a decisão, v.g. - e também permitem diversas perspectivas de observação e, conseqüentemente, opiniões diferentes dos observadores). ${ }^{362}$

Porém, se se está diante da aproximação de um conceito e, como já dito, os conceitos implicam a necessidade de que se leve em consideração a outra parte (o outro lado). Qual é o contraponto e qual é a "forma"363 que permite a um observador indicar uma

\footnotetext{
${ }^{358}$ Sociologia del rischio, Ob. cit., p. 24 e ss.

${ }^{359}$ N. LUHMANN, Sociologia del rischio, Ob. cit., p. 25.

360 Prefácio da obra "Direito, tempo e memória", de RAFFAELE DE GIORGI (trad. de Guilherme Leite Gonçalves, São Paulo: Quartier Latin, 2006, p. 13).

${ }^{361}$ Nas palavras do AUTOR, "Dall'altro lato, inoltre, ache ciò che può accadere in futuro dipende dalla decisione da prendere nel presente: infatti si parla di rischio soltanto quando può esser presa una decisione, senza la quale non potrebbe insorgere alcun danno" (Sociologia del rischio, Ob. cit., 26).

${ }^{362}$ Segundo Luhmann, o conceito de risco envolve um grau elevado de contingência. Ainda segundo ele, o simples fato de duas situações de contigência (o evento e o dano) serem combinadas como contingências já torna possível a divergência de opinião dos observadores (Sociologia del rischio, Ob cit., p. 26).

${ }^{363}$ Por "forma - afirma LUHMANN - intendiamo sempre un confine, una censura che separa due lati, con la conseguenza que bisogna precisare da quale lato si parte nella successiva operazione" (Sociologia del rischio, Ob cit., p. 28). Sobre a noção de "forma", ampliar em Glosario sobre la teoría social de Niklas Luhmann
} 
observação como risco?

Depois de refutar a contraposição tradicional risco/segurança, LUHMANN indica que é o caso de dar outra forma ao conceito de risco. Para tanto, valer-se-á da distinção entre risco e perigo. Segundo ele, ou os eventuais danos são vistos como consequência de uma decisão (e, então, fala-se em risco) ou esses supostos danos seriam decorrentes de fatores externos atribuíveis ao ambiente (e, então, falar-se-ia em perigo).

LUHMANN não concebe um conceito formal de risco, mas um "método" que permita atingi-lo. Segundo ele, "Non si tratta della determinazione formale del concetto di rischio; questa deve essere effetuata secondo la metodologia qui proposta, cioè determinando il concetto opposto e quindi distinguendo delle distinzioni.". 364

E tal "método" é a distinção entre risco e perigo antes indicada.

\subsubsection{A associação do problema da captura à noção de risco}

Segundo LUHMANN, uma das vantagens de se trabalhar com a distinção risco e perigo é a de que essa distinção se coloca no plano das observações de segundo grau e permite, assim, a utilização do conceito de atribuição. Porém, isso não significa que a atribuição a ser levada a efeito (isto é, a indicação de algo como risco ou como perigo) se dá ao acaso. A atribuição de um dano a uma decisão somente é possível se a decisão pode ser atribuída a alguém e se é possível cogitar de uma escolha entre alternativas.

Rigorosamente, a captura pode ser tomada como um risco decorrente da decisão de regular um determinado setor econômico. Diante de um setor econômico específico, o Estado tem a possibilidade de escolher entre diversas alternativas (deixar o setor sujeito ao livre mercado, submetê-lo exclusivamente às regras gerais e abstratas derivadas do Poder Legislativo, regular o setor por meio de órgão vinculado à Administração Pública Direta ou criar um ente regulador setorial e independente). A decisão de regular traz consigo o risco de cooptação do responsável pela regulação por interesses específicos. Mais que isso: a decisão de regular por meio de entes setoriais independentes reforça esse risco.

(Giancarlo Corsi, Elena Espósito e Claudio Baraldi, trad. de Miguel Romero Pérez e Carlos Villalobos, Guadalajara: Universidade Iberoamericana, 1996, p. 84-86).

${ }^{364}$ Sociologia del rischio, Ob. cit., p. 33. 
Para utilizar a nomenclatura cunhada por LUHMANN, entende-se que a captura é um risco inerente à decisão de regular um determinado setor econômico. Tratarse-ia mesmo de um risco, pois há uma decisão que pode ser imputada a alguém (o Estado), que foi adotada diante de uma plêiade de possibilidades que se apresentavam. ${ }^{365}$

Tratar-se-ia de um verdadeiro risco porque tanto a decisão, quanto os danos que dela podem decorrer são contingentes. A decisão poderia ter sido outra, assim como os danos (prevalência real dos interesses regulados ou interesses políticos em detrimento dos demais interesses em jogo) podem (ou não) ocorrer.

Especialmente em relação às agências reguladoras independentes, são ilustrativas as referências de que a utilização de agências reguladoras setoriais implica um reforço para o risco de que a captura (especialmente quando as agências são comparadas com outras que têm atuação que perpassa os diversos setores econômicos). ${ }^{366}$

Essas referências permitem considerar duas circunstâncias relevantes: a decisão de implementar a regulação traz consigo o risco da captura e a possibilidade de que os entes reguladores privilegiem, de modo desproporcional, o interesse dos grupos com interesses específicos (ou seja, a decisão traz consigo a possibilidade de que um dano possa ocorrer). Porém, trata-se de uma possibilidade que pode se implementar (ou não). E, no momento da tomada da decisão, não se pode afirmar categoricamente que os danos inerentes ao risco serão concretizados no futuro.

Assim, entende-se pela possibilidade de reconduzir o fenômeno da captura ao conceito de risco de Luhmann. Porém, não só ao conceito de risco, mas também ao conceito de perigo. Segundo LUHMANN, o risco de um é o perigo para o outro ${ }^{367}$. Assim, por exemplo, a decisão de fumar tem um risco a ela associado (maior propensão em ter um

\footnotetext{
365 Não se olvida que a deliberação do Estado pode, por vezes, ser intensamente influenciada pelas contingências em que está envolvido. Sobre a questão, podem ser consultadas as lições de J. CHEVALLIER citada acima (nota $\mathrm{n}^{\circ} 333$ ). Todavia, não se pode deixar de considerar que, ao fim, a criação de agências reguladoras independentes depende de uma decisão de Estado (no caso brasileiro, de deliberação parlamentar que aprove a lei de criação das agências reguladoras independentes).

${ }^{366}$ Nesse sentido, MARTIN SHAPIRO, Who guards the guardians? Ob. cit., p. 81; PAUL J. QUIRK, Industry influence in Federal Regulatory Agencies, Ob. cit., p. 13-14; MARIA MANUEl LeITÃo MARQUES, Jõ̃O Paulo SimÕes de Almeida e AndRÉ Matos Forte, "Regulação Sectorial e concorrência". Revista de Direito Público da Economia - RDPE. n. 9, Belo Horizonte, p. 194, Quadro 1, jan - mar 2005. A todos os estudos poder-se-ia opor a crítica de que nenhuma das afirmações funda-se em dados objetivos e empíricos. A crítica seria prontamente respondida, ao menos por QUIRK, com as justificativas que impedem a realização de pesquisas empíricas e objetivas sobre o tema (v. item 4.2).

${ }^{367}$ Sociologia del rischio, Ob. cit,. p. 126.
} 
problema de saúde e sofrer os danos daí derivados). Porém, esse risco que é atribuível à decisão e àquele que a adotou, ao mesmo tempo, corresponde a um perigo para os coenvolvidos naquela decisão (no exemplo, as pessoas que não decidiram fumar, mas que suportam os prejuízos para a saúde decorrente da condição de fumante passivo, estariam sujeitas a um perigo).

Diante disso, a captura é um risco inerente à decisão de regular, atribuível ao Estado. Porém, e sob outro ângulo, a captura também é um perigo para os demais coenvolvidos no processo regulatório (consumidores, v.g.).

O que foi exposto instala uma segunda ordem de preocupações. Tomada a captura como um risco derivado da decisão de regular um determinado setor, os danos que podem decorrer desse risco devem ser prevenidos? Ou, para utilizar as palavras próximas àquelas utilizadas por LUHMANN: deve haver uma preparação em relação aos danos futuros incertos, de tal sorte a tentar reduzir a probabilidade de que os danos ocorram ou o vulto dos danos que possam ocorrer? ${ }^{368}$

O próximo item dedica-se a responder essa questão.

\subsection{As justificativas para a prevenção do risco de captura}

O tema da prevenção envolve consideração de pelo menos duas ordens.

Primeiro, no que tange aos riscos, não se pode perder de mira que a prevenção, em si, pode constituir um novo risco. A decisão de se prevenir um risco também pode se revelar um risco: "Il rischio de evitare il rischio resta sempre un rischio." $" 369$

Depois, há de se reconhecer que a questão da prevenção tem um aspecto político, pois é necessário valorar quais são os riscos e os perigos aceitáveis e admissíveis e quais são os que devem ser objeto de prevenção. Até por se tratar de uma questão política, a decisão não coincide necessariamente com os cálculos de probabilidade de que

\footnotetext{
${ }^{368}$ Sociologia del rischio, Ob. cit., p. 39.

${ }^{369}$ Sociologia del rischio, Ob. cit., p. 41. Afinal, a prevenção pode vir a se revelar supérflua. O exemplo do autor é o da decisão de se correr diariamente para evitar males de saúde, mas morrer com a queda de um avião.
} 
determinado evento venha a ocorrer. ${ }^{370}$

$\mathrm{O}$ risco/perigo da captura precisa ser examinado preliminarmente nesse sentido: admitindo que a prevenção traz, em si, novos riscos e perigos, deve-se indagar se é o caso de se implementar medidas que visem prevenir o problema ora examinado.

A resposta à pergunta anterior parece ser positiva (mesmo se tendo em conta que a decisão de prevenir um risco traz, em si mesma, um novo risco).

O exercício da regulação estatal se dá por meio de competências funcionalizadas. ${ }^{371}$ Dá-se por meio de atribuições de um dever-poder, que deve ser exercido tendo em vista os fins a que se destinam e de modo desprendido dos interesses pessoais daquele que exerce a função. Com isso, não se quer dizer que a atuação do regulador deve buscar o "interesse público", como categoria universal e metafísica que se sobrepõe e se opõe aos interesses dos particulares. Diversamente, entende-se que o exercício da regulação envolve uma concreta atividade de ponderação de eventuais interesses em jogo, que precisam ser sopesados e considerados no exercício da regulação. Porém, esse sopesamento deve ser feito de modo imparcial, sem que haja uma prevalência desproporcional de um interesse específico em detrimento dos outros. ${ }^{372}$

Entende-se que o comprometimento dessa imparcialidade e a cooptação do regulador estatal por um grupo de interesses específico pode gerar danos para a integridade econômica do setor regulado (o que, por si, é grave), mas também levar ao comprometimento da própria democracia, especialmente se se admitir que o regulador não integra o setor econômico (isto é, envolve mecanismo heterogêneo de intervenção estatal sobre a economia ${ }^{373}$ ) e que a agência deve inserir-se na realidade democrática. Segundo RAFFAELE De Giorgi, “O problema do sistema da política, conseqüentemente, consiste na

\footnotetext{
${ }^{370}$ O exemplo fornecido por LUHMANN é ilustrativo: na Suécia, os residentes da Lapônia foram retirados de helicóptero enquanto se realizavam testes com mísseis naquela área. E isso não obstante a chance de ocorrer um acidente de helicóptero ser maior que a de alguém ser atingido por um fragmento de míssil durante os testes (Sociologia del rischio, Ob. cit., p. 42).

${ }^{371}$ Nas palavras de RENATO ALESSI, "Il potere statuale appunto, considerato in quanto diretto a queste finalità di interese collettivo ed in quanto oggetto di un dovere giuridico relativamente alla sua esplicazione constituisce una funzione statuale" (Principi di diritto amministrativo. Vol. I, $3^{a}$ ed., Milão: Dott A. Giuffrè Editore, 1974, p. 3).

${ }_{372}^{372}$ Sobre as dificuldades acerca da noção de interesse público, ver item 2.2.2, supra.

${ }^{373}$ Pode até haver dúvida quanto à eficácia desse tipo de medida e, mesmo, não há exatidão quanto ao resultado que poderá produzir. Sobre o tema, podem ser consultadas as referências acima feitas ao trabalho de GUNTHER TEUBNER, segundo quem o sistema econômico pode fazer seis leituras diferentes acerca das normas jurídicas (item 4.2 , acima).
} 
contínua tensão de manter uma alta complexidade e produzir continuamente novas possibilidades de decisões. Dessa perspectiva, então, democrático é o sistema da política que mantém constantemente elevada a complexidade. ${ }^{374}$ Parece provável que a cooptação de um órgão regulador por grupo de interesse específico envolverá uma redução de complexidade, pois restringe as possibilidades de decisão, que sempre será tomada com vistas a beneficiar grupos específicos.

Diante da possibilidade de tais danos, entende-se que é recomendável a decisão que pretenda implementar medidas que possam precaver (isto é, tentar minimizar) esses prejuízos. Diante dos pressupostos de que se parte (incerteza quanto ao futuro, contingência quanto a eventos e danos), tem-se como claro que as eventuais medidas que visem precaver o risco da captura podem tentar minimizar os danos que podem dele derivar, mas não podem evitá-los por completo.

A questão que imediatamente se põe, então, é a de saber quem seria o responsável pela adoção dessas medidas: se o sistema político ou se o sistema jurídico.

O próximo tópico tenta examinar esse tema.

\subsection{A diferenciação funcional dos sistemas jurídico e político e o tratamento dos riscos}

\subsubsection{A diferenciação funcional dos sistemas jurídico e político}

Política e Direito são sistemas sociais parciais funcionalmente diferenciados. Cumprem funções diferentes e operam a partir de códigos binários diversos (que permitem a reprodução autopoiética do sistema e o seu fechamento operacional). A aplicação dos códigos é orientada por "programas", que estabelecem os critérios para a atribuição de valores aos códigos. ${ }^{375}$

A função da política é a de adotar decisões que vinculem a coletividade. A partir dos códigos superior/inferior e governo/oposição leva a efeito as operações no

\footnotetext{
374 "Democracia, parlamento e opinião pública na sociedade contemporânea", Direito, democracia e risco: vínculos com o futuro. Porto Alegre: Sérgio Fabris, 1998, p. 41.Ampliar em CELSO FERNANDES CAmPIlongo, Política, sistema jurídico e decisão judicial. São Paulo: Max Limonad, 2001, p. 71.

${ }^{375}$ Segundo ELENA ESPOSITO, "Los programas se definen en general como conjuntos de condiciones para la corrección. Con referencia a los códigos, los programas son aquello que establece los criterios para la correcta atribución de los valores de tales códigos, de tal manera que un sistema que se oriente hacia ellos pueda alcanzar la complejidad estructurada y controlar el propio proceder." (Glosario sobre la teoría social de Niklas Luhmann. Ob. cit., p. 131-132, verbete: "programa")
} 
interior do sistema, permitindo a variação, seleção e estabilização das decisões coletivamente vinculantes. ${ }^{376}$ A operação dos códigos é orientada por "programas", que correspondem aos programas político-eleitorais e aos programas de governo. Em outras palavras: esses programas orientam a aplicação dos códigos do sistema político e, como resultado, tem-se a reprodução autopoiética desse sistema e o desempenho da função especificamente por ele cumprida: a tomada de decisões que vinculam a coletividade.

Por sua vez, a função do direito é a da generalização congruente das expectativas normativas. A partir da aplicação do código lícito/ilícito, o direito tem condições de definir o que é comportamento conforme (lícito) e o que é comportamento desviante (ilícito), mantendo as expectativas normativas, que não se alterarão pela circunstância de terem sido contrariadas pelos fatos (isto é, a infração a uma determinada lei não implica, por si só, que a respectiva lei se altere ${ }^{377}$ Como já se pode antever, os programas que orientam a aplicação do código lícito/ilícito são os programas normativos (leis, contratos, regulamentos etc.).

Note-se, ainda, que o modo de organização dos programas com que trabalham a política e o direito também é diferente. Programas que orientam a aplicação dos códigos operativos dos sistemas sociais podem ser condicionais ou finalísticos. A diferença está na circunstância de que os programas condicionais estabelecem como critério de avaliação da decisão a presença de determinadas condições (se A ocorre, o comportamento B é devido). Por sua vez, a avaliação de decisões a partir de programas finalísticos depende de que as consequências esperadas realmente ocorram.

A produção legislativa (portanto, a atividade do sistema político) envolve programas finalísticos. Envolve a adoção de uma decisão programante, que tem em mira determinadas consequências. As decisões judiciais (portanto, a atividade do sistema jurídico) relacionam-se com programas condicionais. Trata-se de decisões programadas de

\footnotetext{
${ }^{376}$ Celso Fernandes CAMPILOngo, Política, sistema jurídico e decisão judicial. Ob. cit., p. 71.

377 Cláudio BARALDI, Glosario sobre la teoría social de Niklas Luhmann. Ob. cit., p. 81. Isso não significa que as expectativas normativas não se modifiquem. Uma das características fundamentais do direito positivo é a possibilidade de mutação. Porém, essa alteração não se dá de forma diretamente conectada a uma singular frustração de uma específica expectativa normativa. Sobre as dificuldades de se operação do código lícito/ilícito no contexto de complexidade da sociedade atual, consultem-se as lições de NiKLAS LUHMANN mencionadas na nota $\mathrm{n}^{\circ} 393$, abaixo.
} 
acordo com as condições estabelecidas pelo ordenamento jurídico. ${ }^{378}$

\subsubsection{O tratamento do risco pelo sistema político e a repercussão para o sistema jurídico}

Conforme exposto em tópico anterior, cabe à política adotar as decisões que vinculam a coletividade. Assim, a decisão de regular (ou não) parece ser uma típica decisão política, ou seja, a decisão arriscada de regular parece ser manifestação típica da função do sistema político. Mas e o tratamento do risco (para o Estado) e do perigo (para os demais envolvidos) inerente à decisão? Cabe a quem? Também parece ser o sistema político o mais apto a adotar as decisões que implementem as medidas preventivas que possam reduzir o risco e o perigo de captura.

Na medida em que a função do sistema político é a de tomar decisões que vinculam a coletividade, as medidas de prevenção também parecem envolver a implementação de decisões desse tipo. Nas palavras de RAFFAELE DE GIORGI, “A política é sempre mais a destinatária de prevenções de miniminizações do risco, de reduções do risco a níveis toleráveis". ${ }^{379}$ Por um lado, o sistema político pode observar o comportamento arriscado e tentar regular o eventual comportamento que lhe possa dar causa. ${ }^{380}$ Por outro, cabe a ele processar as pressões relacionadas à circunstância de que o risco inerente a determinada decisão envolve um perigo para os que dela não participaram, bem como adotar (ou não) decisões de prevenção a esses riscos ou perigos.

Admitindo-se que o sistema político entenda oportuno tentar prevenir o risco e o perigo da captura, adotará decisões coletivamente vinculantes que implementem os mecanismos que podem reduzir a possibilidade de os danos daí derivados se concretizarem. Normalmente, essas decisões vinculantes terão formas normativas (regras jurídicas que visam definir o modo de funcionamento dos órgãos reguladores e o próprio

\footnotetext{
378 Niklas Luhmann, Sociologia do Direito. Tradução de Gustavo Bayer, vol. II, Rio de Janeiro: Edições Tempo Brasileiro, 1985, p. 27-34. Ainda que algumas decisões judiciais possam (ou tenham de) levar em conta o futuro, tomam-no como o futuro se mostra no presente. Não será o futuro que decidirá o que é (e o que não é) conforme ao direito. Confira-se NiKLAS LuHMANN, El derecho de la sociedad. Trad. de Javier Torres Nafarrate, México: Universidad Iberoamericana, 2002, p. 259. Sobre a diferença dos programas de que se valem a política e o direito, ampliar em Celso FERnANDES CAMPILONGO, Política, sistema jurídico e decisão judicial. Ob. cit., p. 103.

379 "O Direito na sociedade do risco", Direito, tempo e memória. Ob. cit., p. 235.

${ }^{380}$ Segundo LUHMANN, "Il sistema politico può osservare il comportamento rischioso e, osservando, riferirsi a cause, a strutture oppure a ricorrenze statistiche. Se il comportamento umano viene identificato come causa, si può tentare di regolarlo, qualunque cosa poi accada di diverso da prima" (Sociologia del rischio. Ob. cit., p. 167).
} 
comportamento dos agentes que funcionam como reguladores). ${ }^{381}$ Essas normas jurídicas funcionarão como "programas" para o direito, que poderá reputar como ilícitas as condutas que se desviem das normas jurídicas em questão.

Assim, por meio das normas jurídicas, o tratamento do risco pode se infiltrar no sistema jurídico. Caso haja normas jurídicas que busquem reduzir os danos derivados do risco e do perigo da captura, o direito poderá tratar desse risco. Note-se, porém, que esse exercício é limitado: o direito decidirá que algo é lícito/ilícito porque respeita (ou não) as regras e princípios que organizam o funcionamento dos órgãos reguladores e dos próprios agentes públicos responsáveis pelo exercício da regulação. Não decide se algo é lícito/ilícito porque há regulação que, como tal, traz consigo o risco e o perigo da captura.

Porém, as próprias normas são limitadas para o tratamento do risco.

As normas envolvem a definição, no presente, de como deve ser a conduta futura. Os julgamentos feitos a partir dela verificam se uma determinada conduta é conforme ou desviante do direito, mantendo intactadas as expectativas normativas. Porém, essas normas não podem garantir que os riscos serão evitados, como também não podem ser substituídas pelos próprios "riscos".

Por um lado, e como já ficou acima explicitado, os riscos e os perigos envolvem um alto nível de contingência. A própria decisão de tentar prevenir um risco é arriscada e sempre há a possibilidade de a prevenção se configurar como supérflua.

Por outro, as normas são formas de vínculo temporal, que permitem a estabilização de expectativas (mesmo quando essas expectativas são frustradas). Devem manter uma forma que permita distinguir comportamentos conformes ao direito daqueles que não o são. Caso as normas sejam substituídas pelos "riscos" e "perigos" propriamente ditos, não se terão parâmetros que permitam distinguir o que é lícito e o que é ilícito.

Como esclarece LUHMANN,

Nel caso dei rischi no si tratta affatto di un futuro in riferimento al quale si debba stabilire nel presente come gli altri si dovranno comportare in situazioni future. I rischi non possono essere violati.

Se si pretende dal diritto che si assuma dei rischi, questo può accadere soltanto detemporalizzando il giudizio sulla correttezza o meno delle decisioni. I simboli come il valore legale o la validadità giuridica, in altre parole, devono essere introdotti 'in maneira vincolante' senza curarsi si il futuro

${ }^{381}$ Como detecta RAfFAele De GiORgi, é a política a destinatária a dar tratamento ao risco. Porém, as decisões políticas assumem formas jurídicas (“O Direito na sociedade do risco”, Ob.cit., p. 235). 
dimonstrerá che una decisione è stata correta o sbagliata. ${ }^{382}$

Caso riscos tomem o lugar das normas, o direito não cumprirá mais a sua função. ${ }^{383}$ Não há como generalizar de modo congruente expectativas normativas quando normas vinculantes dão lugar a riscos e perigos (por essência contingentes e sujeitos à verificação futura).

${ }^{382}$ Sociologia del rischio, Ob. cit., p. 71.

${ }^{383}$ É verdade que a positivação do direito permite que os programas com que trabalha o sistema jurídico (portanto, as normas jurídicas) sejam alteradas (NiKLAS LuHMANn, Sociologia do Direito, vol. II, Ob. cit., p. 7-17). E, nessa alteração, é possível que o novo programa a orientar as decisões do sistema jurídico haja tomado eventuais riscos que se apresentavam em outros subsistemas sociais. A esse respeito, ver o trabalho de DomenICo TOSINI acerca da alteração do critério de aferição da responsabilidade civil que, paulatinamente, caminha da culpa para a responsabilidade objetiva, permitindo que os ônus de determinada decisão arriscada recaia sobre aquele que a tomou em vez de ser imposta àquele que sofreu os seus efeitos ("The welfare courts: a sócio-legal analysis of risk management modern strict liability". International Journal of the Socioloby of Law. vol. 33, 2005, p. 200-214). Porém, nesse caso, o sistema jurídico funciona a partir das normas que incoporaram os riscos (e, não, dos riscos eles mesmos). Por outro lado, é de se notar que as normas não se prestam a eliminar todos e quaisquer riscos. Podem, quando muito, tratar alguns deles e tentar minimizá-los, mas não podem substitui-los por completo. Não fosse só isso, quando pretender levar adiante o tratamento de alguns riscos trazem consigo a criação de novos riscos. A esse respeito, podem ser conferidas as lições de HENRY ROTHSTEIN, MICHAEL HUBER e GEORGE GASKELL acerca da regulação sobre riscos, também aqui aplicável: "Regulator, therefore, have only a limited capacity to control societal risks. The difficulty in satisfaying conflicting demands on regulation, therefore, creates institutional risks that can threaten the legitimacy of regulatory organizations and their practices" "A theory of risk colonization: the spiraling regulatory logics of societal and institutional risk" [on line]. London: LSE Research Online. Disponível em: <http://eprints.lse.ac.uk/2675>.Último acesso em: 1.10.2009, p. 5). 


\section{CAPÍTUlO 5: A PREVENÇÃO DO RISCO DE CAPTURA - LIMITES E POSSIBILIDADES}

Conforme exposto no item anterior, tem-se que o risco da captura deve ser tomado pelo sistema político, que poderá, por meio de normas jurídicas, tentar preveni-lo. A atuação do sistema jurídico será na aplicação dessas normas previamente postas (isto é, a aplicação do programa a partir do qual o sistema jurídico opera). Dessa forma, é o caso de se investigar as normas jurídicas já existentes que podem, de algum modo, contribuir para minimizar o problema da captura. O presente capítulo propõe-se a efetuar esse exame. Antes, contudo, apresenta-se a relação que se estabelece entre duas situações fáticas próximas: o risco de captura e a prática do lobby.

\subsection{A circunstância fática próxima da captura: lobby}

Há muito, discute-se o significado da expressão lobby ou lobbying. ${ }^{384} \mathrm{De}$ toda a forma, e em especial no Brasil, é corrente a tendência de se associar a prática do lobby a práticas de corrupção e tráfico de influências (isto é, a cometimento de ilícitos penais). ${ }^{385}$ No presente trabalho, refuta-se essa associação, entendendo-se pela necessidade de que se diferenciem as práticas de lobby estritamente consideradas daquelas que possam configurar a prática de ilícitos penais (corrupção ativa e passiva, concussão, tráfico de influência, prevaricação, advocacia administrativa, entre outras). Se é certo que podem existir "áreas cinzentas" - para usar a expressão de LUIGI GRAZIANO - em que lobby e corrupção se interpenetram, é igualmente correto indicar que "em princípio, a linha de demarcação é bastante nítida". ${ }^{386}$ O lobby seria, portanto, o exercício de pressão, mediante o emprego de instrumentos lícitos, levado a efeito por grupos de interesses ou por profissionais contratados por esses grupos de interesses, com vistas a apresentar e a

\footnotetext{
${ }^{384}$ A respeito das dificuldades de se precisar o significado da expressão, ver JAMES H. TELBERRY, "Lobbying - a definition an recapitulation of its practice". Ohio State Law Journal. vol. 11, 1950, p. 557-558.

${ }^{385}$ Sobre essa tendência, consultar a tese de ANDRÉA C. J. OLIVEIRA. "Lobby e Representação de Interesses: lobistas e seu impacto sobre a representação de interesses no Brasil". Tese de Doutorado apresentada ao Instituo de Filosofia e Ciências Humanas da Universidade Estadual de Campinas, 2004, p. 27-31.

386 "Lobby e o interesse público". Trad. de Vera Pereira. Revista Brasileira de Ciências Sociais. vol. 12, n. 35, São Paulo, fev-1997, p. 5. A versão consultada está disponível em: <http://www.scielo.br/scielo.php? script=sci_arttext\&pid=S0102-69091997000300009). Último acesso em: 15.06 .2009 (a paginação aqui mencionada segue a da versão consultada). Segundo GRAZIANO, lobby e corrupção seriam práticas que se excluem mutuamente. Isso porque, o exercício de pressão, puro e simples, é atividade que exige emprego de recursos consideráveis e os resultados que podem daí derivar são incertos. Se meios mais diretos e mais eficazes quanto à obtenção de resultados - tal como seria a corrupção - estiverem à disposição, serão eles os empregados (e não o lobby). Assim, e para esse autor, há pouco espaço para o lobby em locais em que a corrupção é generalizada e assume dimensões sistêmicas (LUIGI GRAZIANO, "Lobby e o interesse público". Ob. cit., p. 5).
} 
defender a visão desse grupo em face dos Poderes Públicos responsáveis pela tomada de decisão política. Porém, "Fazer lobby não é apenas exercer pressão. A pressão é o último estágio de um processo multifacetado que inclui reunir informações, preparar projetos de políticas e uma estratégia adequada para a defesa desses projetos, procurar aliados e outras providências. ${ }^{, 387}$ Há, portanto, um conjunto de atividades (todas lícitas), que viabilizam o exercício dessa pressão. Para Luigi GraziAno, o mais relevante da atividade de lobby é o fato de que ele é apto a fornecer conhecimento especializado acerca de determinada área de atuação. Em outras palavras: as informações trazidas por aquele que exerce o lobby tende a ser quantitativa e qualitativamente melhor e maior que a detida pelo responsável pela toma de decisão. ${ }^{388} \mathrm{E}$, nessa medida, pode auxiliar o bom exercício dos poderes públicos. Devese anotar, ainda, que o exercício de pressão por meio do lobby não deixa de ser manifestação dos grupos de pressão, de molde que há a tendência de que grupos compostos por um número menor de participantes e com interesses mais coesos consigam se organizar de modo mais eficiente e recorrer com mais frequência e maior efetividade ao exercício de pressão.

Em primeiro exame, lobby e captura distinguir-se-iam pelo locus em que são encontrados. Enquanto o lobby conecta-se mais diretamente à atividade do Poder Legislativo, a captura relacionar-se-ia de forma mais próxima com o Poder Executivo. Contudo, essa distinção, a par de ser secundária, não é precisa (mormente quando se toma em consideração a realidade brasileira). Isso porque o lobby não é fenômeno específico de atuação de grupos de interesse em face do Poder Legislativo. É plenamente possível que essa atuação de grupos de interesse ocorra no âmbito da tomada de decisões do Poder Executivo. Aliás, diante da configuração da "divisão de poderes" no Estado Brasileiro e a respectiva preponderância do Poder Executivo, não é de se supor que os grupos de interesse não exerçam pressão sobre o Executivo. ${ }^{389} \mathrm{E}$, ontologicamente, não há diferença entre exercer pressão no processo de tomada de decisões no âmbito do Legislativo e

\footnotetext{
${ }^{387}$ LUIGI GRAZIANO, "Lobby e o interesse público". Ob. cit., p. 6.

${ }^{388}$ LUIGI GRAZIANO, "Lobby e o interesse público". Ob. cit., p. 6

389 A respeito, ampliar em ANDRÉA C. J OLIVEIRA. "Lobby e Representação de Interesses: lobistas e seu impacto sobre a representação de interesses no Brasil" Ob. cit., p. 34 e ss. ELI DINIZ também destaca a precedência do Executivo sobre o Legislativo ("Empresário, democracia e desenvolvimento: tendências e desafios no limiar do novo milênio", 2004. Disponível em: <http://neic.iuperj.br/artigos.html $>$. Último acesso em: 15.06.2009). De toda a forma, a AUTORA destaca que, ao final da década de 1980, depois da experiência da Assembleia Constituinte, assistiu-se a um deslocamento das ações de grupos de interesse. Algumas ações que antes eram dirigidas ao Poder Executivo passaram a ser dirigidas ao Legislativo por meio da prática de lobby. ("Empresário, democracia e desenvolvimento: tendências e desafios no limiar do novo milênio", 2004, p. 24. Disponível em: 〈http://neic.iuperj.br/ artigos.html〉. Último acesso em: 15.06.2009).
} 
exercer pressão no processo decisório do Poder Executivo. ${ }^{390}$ Poder-se-ia diferenciar os dois fenômenos a partir do tipo de decisão pública de que tratam. O lobby estaria vinculado à tomada de decisões políticas em sentido amplo e a captura estaria vinculada ao exercício de competências regulatórias, com vistas a implementar aquelas decisões políticas. ${ }^{391}$ A diferença também não é absolutamente precisa. Tal como destacado em passagem anterior, a teoria econômica que primeiramente identifica o problema da captura não faz distinção entre a ocorrência do problema no manejo das competências exercidas pelo Legislativo (isto é, das competências utilizadas na fixação de decisões políticas) e aquelas exercidas pelas agências responsáveis pela regulação do setor. ${ }^{392}$

Assim, entende-se que a melhor distinção entre os dois fenômenos parecer ser a diferença entre meio e resultado. Em uma só palavra, lobby equivale a "pressão". É, portanto, meio pelo qual os grupos de interesse pretendem obter a prevalência de seu ponto de vista na tomada de decisão. A captura do responsável pela tomada de decisões, por sua vez, é um dos resultados que pode derivar desse exercício de pressão. Assim, lobby e captura são fenômenos diversos, mas que se relacionam, na medida em que o primeiro pode ser meio que gera, como resultado, a segunda.

\subsection{As teorias jurídicas existentes para situações de fronteira de legalidade}

É certo que a captura do responsável pelo exercício da regulação pode ocorrer por meio da prática de eventuais ilícitos (penais ou administrativos). Nesses casos, o problema será tratado com os instrumentos do Direito Penal e do Direito Administrativo Sancionador, respectivamente. E, nessa medida, o problema encontra tratamento direto pelo sistema jurídico. Ocorre, no entanto, que a faceta mais complexa do problema da captura não é a parcela que coincide com a eventual prática de ilícitos. Diversamente, o tratamento do problema torna-se mais difícil quando as condutas empreendidas revestem-

\footnotetext{
${ }^{390}$ Isso parece ser reconhecido pela legislação norte-americana. Enquanto o Federal Regulation of Lobby Act (1946) regulamentava somente os contactos entre lobistas e membros do Congresso, o estatuto que o substitui (Public Disclosure Act, de 1995) abrange, também, os eventuais contactos entre lobistas e a Administração Pública. As referências legislativas foram retiradas de LUIGI GRAZIANO, "Lobby e o interesse público". Ob. cit., p. 6.

${ }^{391}$ Sobre a diferença entre políticas de Estado, políticas de Governo, políticas públicas e política regulatória, ver FlORIANO AZEVEDO MARQUES NETO (“Agências reguladoras: instrumentos do fortalecimento do Estado, São Paulo: ABAR, [s/d], p. 38 e ss).

${ }^{392}$ Ver item 2.1.2., b, acima. Afinal, o fato de o presente trabalho limitar-se à investigação da questão no âmbito das agências reguladoras não significa que problema similar (ou, quiçá, idêntico) não possa ocorrer em outra seara. Em outras palavras, e como é evidente, o recorte levado a efeito no presente trabalho - e que tem finalidade estritamente metodológica - não altera a realidade. Não exclui a ocorrência do problema aqui investigado em âmbitos diversos dos aqui tratados.
} 
se de legalidade. ${ }^{393}$ Quando isso ocorre, a questão é a de investigar em que medida é possível cogitar de controle da atividade dos grupos de interesse e, mesmo, do regulador. Embora sem cogitar do problema que aqui se trata, fato é que a dogmática jurídica desenvolveu teorias - hoje, consagradas no direito positivo - que lidam com situações que se encontram na fronteira entre legalidade e ilegalidade. É o que se dá com as teorias do "abuso de direito" e do "desvio de poder" (ou "desvio de finalidade"). Embora com campos de atuação distintos, as teorias se aproximam justamente no ponto em que buscam tratar casos que, embora abstrata e formalmente encontrem amparo no ordenamento jurídico, acabam por desbordar dos limites da legalidade. ${ }^{394}$ Assim, e na medida em que podem auxiliar o tratamento da captura nessa "zona de fronteira", faz-se necessário examinar cada um desses institutos e a eventual contribuição que podem proporcionar para o tratamento da captura.

\subsubsection{O abuso de Direito}

$\mathrm{O}$ art. XXXIV, $a$, da Constituição Brasileira assegura o direito de petição a pessoas físicas e jurídicas (nacionais e estrangeiras). Esse direito - que já encontrava

${ }^{393}$ A esse respeito, ainda que longa, merece transcrição a lição de NIKLAS LUHMANN sobre a questão: "Com os recentes desenvolvimentos da sociedade e do direito essas incertezas aumentam e modificam sua forma. As ameaças através de outras pessoas passam a ser juridicamente combatidas, mas também permitidas. Agora, os perigos surgem em grande parte a partir do próprio direito. Por isso as trincheiras contra o perigo não podem mais ser erigidas no terreno da oposição entre o legal e o ilegal; elas atravessam o próprio direito como regulamentação e distribuição dos riscos: lei podem ser modificadas, mas só no contexto da constituição e de determinadas dificuldades; contratos podem ser denunciados, mas só por motivos especiais; direitos subjetivos podem ser desapropriados, mas só no interesse público e através de indenizações; permitem-se ações cujos resultados já se supõem danosos, mas para isso já se prevê uma responsabilidade por risco de danos. A importância desse tipo de regulamentação cresce comparativamente. É verdade que ainda pode ocorrer que um ladrão roube minha prataria, mas qual é a relevância disso em comparação com a falência do meu banco, a demissão do meu emprego, a mudança do código de obras do meu município, a greve nas minhas fábricas, ou até a greve em importantes serviços públicos? Em vista dessas ameaças agora juridicamente permitidas, torna-se necessário redefinir o conceito e a sensação do problema da segurança. Não se trata mais de segurnaça contra ações ilegais, de proteção jurídica, mas de segurança contra ações legais, envonvendo, portanto, complicadas disposições contrárias no próprio direito, que exigem constantes controles e adaptações jurídico-políticos. Por isso, o direito atual não é mais capaz de garantir aquela certeza moral das expectativas que resulta do simples fato de alguém julgar-se no direito" (Sociologia do Direito, vol. II, Ob. cit., p. 54-55).

${ }^{394}$ Nesse sentido, EVERARDO DA CUNHA LUNA ao afirmar que a "lógica" do abuso de direito é a mesma da presente no "desvio de poder". Nas palavras do autor: "No abuso de direito, tem-se o direito, embora viciado; no défaut de droit, não se tem o direito, simplesmente. Sucede o mesmo, em direito administrativo, com o desvio e o excesso de poder; no desvio de poder, tem-se o poder e se desvia ele dos fins, a que se propõe o direito; no excesso de poder, usa-se de um poder que a ordem jurídica não reconhece." (Abuso de Direito. Rio de Janeiro: Forense, 1959, p. 102). Por sua vez, VICTOR NUNES LEAL destaca que "Quem abusa de seu direito excede os limites em que lhe era lícito agir e pratica um ato que se equipara, por suas conseqüências, ao ato ilícito. Do mesmo modo, se a Administração abusa do seu poder discricionário, excede os limites da ação discricionária, penetrando no terreno da ação arbitrária, equiparado o seu ato a um ato ilegal" ("Poder discricionário e ação arbitrária da Administração", Revista de Direito Administrativo. vol. XIV, out-dez 1948 , p. 80).Note-se, portanto, que essa proximidade é detectada tanto por aqueles que estudam o "abuso de direito", como pelos estudiosos que se dedicam a examinar o "desvio de poder". 
previsão em todos os anteriores Textos Constitucionais brasileiros ${ }^{395}$ - pode ser definido “como aquele que, exercitável por qualquer pessoa, tem por objetivo apresentar um pleito de interesse pessoal ou de interesse coletivo, visando com isto obter uma medida que considera mais condizente com o interesse público". ${ }^{396}$ O direito de petição, todavia, não se encerra na possibilidade de formular um pleito perante o Poder Público. Vai além para abranger, também, o direito de obter uma resposta para o pedido formulado. Como bem consigna CElso Antônio BANDEIRA DE Mello, "A Constituição consagra o direito de petição (art. $5^{\circ}$, XXXIV, 'a') e este presume o de obter reposta. Com efeito, simplesmente para pedir ninguém precisaria de registro constitucional assecuratório, pois não se imaginaria, em sistema algum, que pedir fosse proibido."397

Nessa medida, pode-se compreender o direito de petição como um direito subjetivo público. Se os direitos subjetivos têm como nota "um poder de exigir" 398, o modo como é estruturado o direito de petição - possibilidade de formular um pedido conjugada com o poder jurídico de exigir uma resposta do Poder Público - permite afirmar que se trata de um direito subjetivo. Seria um direito subjetivo público porque, além de clara individualização, a exigência que se pode formular (a de obter uma resposta para o pleito apresentado) dirige-se aos Poderes Públicos em geral e à Administração Pública em particular. ${ }^{399}$ Ainda que em obiter dictum, o Supremo Tribunal Federal salientou que "O direito de petição qualifica-se como prerrogativa de extração constitucional assegurada à generalidade das pessoas pela Carta Política (art. $5^{\circ}, \mathrm{XXXIV}$, a). Traduz direito público

395 Conforme informam Gilmar Ferreira Mendes, InocÊNCIO Mártires Coelho e Paulo Gustavo Gonet Branco, Curso de Direito Constitucional. $2^{\mathrm{a}}$ ed., São Paulo: Saraiva, 2008, p. 566.

${ }^{396}$ Celso Ribeiro Bastos, Comentários à Constituição do Brasil. $2^{\circ}$ volume, São Paulo: Saraiva, 1989, p. 166.

${ }^{397}$ Curso de Direito Administrativo. Ob. cit., p. 380.

398 Expressão de BONNARD, referida por Miguel SEABRA FAGUNDES, na obra $O$ controle dos atos administrativos pelo Poder Judiciário. Atual. por Gustavo Binenbojm, $7^{\mathrm{a}}$ ed., Rio de Janeiro: Forense, 2006, p. 210.

399 Miguel Seabra Fagundes, $O$ controle dos atos administrativos pelo Poder Judiciário. Ob. cit., p. 210211. Além de a exigência se voltar contra os Poderes Públicos, Seabra Fagundes também destaca a necessidade de individualização dos direitos, a fim de que possam ser tomados como direitos subjetivos públicos. Segundo o AUTOR, há várias obrigações impostas ao Estado pelo direito objetivo sem que haja a individualização do beneficiário. Nesse contexto, só se falará em "poder de exigir" quando o administrativo se apresente como interessado imediato na prestação $(O$ controle dos atos administrativos pelo Poder Judiciário. Ob. cit., p. 210). Embora a questão possa gerar dificuldades (mormente para o eventual reconhecimento de direitos sociais como direitos subjetivos públicos), o problema não se coloca no contexto do direito de petição. Por certo, o titular do direito subjetivo público em questão é aquele que formula o pleito. Nesse ponto, é necessário não se confundir o teor do direito de petição e o eventual direito que se pleiteia. $\mathrm{O}$ direito de petição concede o direito de obter - e exigir - uma resposta. Se o mérito do pedido envolve (ou não) um direito subjetivo do administrado que formula o pleito é uma questão diversa. 
subjetivo de índole essencialmente democrática." ${ }^{400}$

A temática se relaciona com o presente trabalho na medida em que a atuação dos grupos de interesse perante os responsáveis pelo exercício da regulação pode se dar por medidas que expressam exercício do direito de petição, seja ao inaugurar eventual processo perante as agências reguladoras independentes, seja ao participar de processos já instalados pela própria agência ou por outros interessados. A dúvida está em saber se é possível haver abuso no exercício do direito de petição. E, em caso positivo, verificar em que medida essa identificação pode ser utilizada para auxiliar no tratamento do problema da captura.

A idéia de abuso de direito remonta à noção medieval de atos emulativos, recuperada pela jurisprudência francesa para coibir situações em que o direito subjetivo foi exercido de molde a prejudicar injustificadamente o interesse de outrem. ${ }^{401}$ Desde então, a figura é estudada pelo Direito Civil com o desenvolvimento de diferentes conceitos e critérios para a identificação da abusividade. ${ }^{402}$

No presente trabalho, não há espaço para o estudo de cada uma das vertentes teóricas. Elas são aqui expostas exclusivamente na tentativa de identificar a ideia basilar que subjaz as principais teorias a respeito do tema. Com esse objetivo, utiliza-se a sistematização feita por EDUARDO FERREIRA JORDÃO, segundo quem é possível agrupar as teorias sobre abuso de direito em seis vertentes, considerando, dentre outros pontos, a

\footnotetext{
${ }^{400}$ Supremo Tribunal Federal, Pleno, Agravo Regimental em Ação Rescisória 1354, Relator Ministro Celso DE Mello, DJ 06.06.1997.

${ }^{401}$ Eis a síntese de MENEZES CORDEIRO relativamente a tais casos:

"As primeiras decisões judiciais do que, mais tarde, na doutrina e na jurisprudência viria a ser conhecido por abuso de direito, datam da fase inicial da vigência do Código de Napoleão. Assim, em 1808, condenou-se o proprietário duma oficina que, no fabrico de chapéus, provocava evaporações desagradáveis para a vizinhança. Doze anos volvidos, era condenado o construtor de um forno que, por carência de precauções, prejudicava um vizinho. Em 1853, numa decisão universalmente conhecida, condenou-se o proprietário que construíra uma falsa chaminé para vedar o dia a uma janela do vizinho, com quem andava desavindo. Um ano depois, era a vez do proprietário que bombeava, para um rio, a água do próprio poço, com o fito de fazer baixar o nível do do vizinho. Seguir-se-iam, ainda, numerosas decisões similares, com relevo para a condenação, em 1913, confirmada pela Cassação, em 1915, por abuso do direito, do proprietário que erguera, no seu terreno, um dispositivo dotado de espigões de ferro, destinado a danificar os dirigíveis construídos pelos vizinhos." (Da boa fé no direito civil. Coimbra: Almedina, 1987, p. 671).

${ }_{402}$ Tal como consignam Gustavo Tepedino, Heloísa Helena Barboza e Maria Celina Bodin de MORAES, "A vasta diversidade de conceituações e critérios de aferição da abusividade deriva do fato de ser o abuso de direito uma construção de natureza essencialmente jurisprudencial, nascida da análise de problemas concretos à luz de cada sistema jurídico particular" (Código Civil interpretado conforme a Constituição da República. Vol. I, $2^{\mathrm{a}}$ ed. rev. e atual., Rio de Janeiro: Renovar,2007, p. 345).
} 
explicação para a relação entre o ato abusivo e o direito subjetivo. ${ }^{403} \mathrm{~A}$ primeira, denominada tradicional, compreende o abuso de direito como direito subjetivo exercido em contrariedade ao direito objetivo (JOSSERAND). A segunda envolve a idéia de um escalonamento de preferências no ordenamento jurídico. Fala-se em abuso de direito quando o exercício do direito subjetivo implica violação de outro direito que é preferencialmente protegido pelo ordenamento (Desserteaux, Alvino Lima, PONTES DE MIRANDA). A terceira vê no abuso de direito uma natureza metajurídica, ou seja, os atos são juridicamente lícitos, mas contrariam a moral ou a consciência social de justiça (Rotondi e JEAN DABIN). A quarta é a tese de que o abuso de direito implica violação à funcionalidade social do direito subjetivo. $\mathrm{O}$ ato é, em princípio, lícito, mas foi colocado a serviço de fins ilegítimos (JOSSERAND). O quinto conjunto de teses diferencia limites externos e internos do direito subjetivo. Ainda que não ultrapasse os "limites externos", o ato é tido por abusivo porque ultrapassa os limites internos do direito subjetivo (PASCAL ANCEL e JACQUES GHESTIN). Por fim, há a tese da violação ao valor imanente ao direito subjetivo. $\mathrm{O}$ ato abusivo seria formalmente lícito, mas materialmente ilícito (FERNANDO Augusto Cunha de Sá, Castanheira Neves e Jorge Manuel Coutinho de Abreu). ${ }^{404}$

Não obstante a diversidade teórica, é possível identificar que o ponto de partida de todas as teorias é o mesmo: o ato praticado é, em princípio, concorde com o ordenamento jurídico, pois expressão do exercício de um direito subjetivo. Porém, em um segundo momento, ele se revela abusivo. E, então, é à abusividade que se emprestam diferentes explicações: contrariedade ao direito objetivo, a outro direito subjetivo preferencialmente protegido, à moral ou à consciência social de justiça, à funcionalidade social do direito subjetivo, aos limites internos do direito subjetivo ou aos valores imanentes ao direito subjetivo. ${ }^{405}$

A figura do abuso de direito é aplicável aos direitos subjetivos públicos, pois a qualificação "pública" não lhes retira a natureza de direito subjetivo. ${ }^{406}$ Aliás,

\footnotetext{
${ }^{403}$ EDUARDO FERREIRA JORDÃo, Repensando a teoria do abuso de direito. Salvador: JusPODIVM, 2006, p. 65 .

${ }^{404}$ EDUARDO FERREIRA JORDÃo, Repensando a teoria do abuso de direito, Ob. cit., p. 65-98.

${ }^{405}$ No Direito Brasileiro, a previsão de vedação ao abuso de direito consta do art. 187 do Código Civil. Antes dele, a vedação derivava da interpretação, a contrario sensu, do art. 160, I, segunda parte, do Código Civil de 1916

${ }^{406}$ Sob outro enfoque argumentativo (compreendendo que o legislador, ao erigir certo direito como fundamental, não é uniciente e não tem como prever todas as nuances que os casos concretos podem apresentar), JUAN RUIZ MANERO admite que "puede haber situaciones em las que quepa un uso no justificado - esto es, un abuso - de reglas que constituyan uma concreción de derechos fundamentales"
} 
exemplo de situação em que se tem reconhecido a ocorrência de abuso de direito de direito subjetivo público é a do abuso de direito de demandar em juízo, ou seja, situação de abuso do direito de petição conjugado com o de ação (também constitucionalmente previsto no art. $5^{\circ}, \mathrm{XXXV}$, do $\left.\mathrm{CF}\right) .{ }^{407}$ Em sentido similar, tem-se reconhecido o abuso do direito de recorrer, constitucionalmente protegido pelo art. $5^{\circ}, \mathrm{LV}, \mathrm{da} \mathrm{CF} .{ }^{408}$

Em que medida, então, é possível se cogitar de abuso no exercício do direito de petição e de que modo a figura do abuso de direito pode auxiliar no tratamento do problema da captura? O primeiro aspecto a se considerar envolve o reconhecimento da possibilidade de abuso de direito no exercício de direito de demandar (uma das facetas do direito de petição). A segunda, mais delicada, envolve a sham exception da doutrina NoerrPennington. Ambas são analisadas na sequência.

\section{a) O abuso do direito de demandar}

O atual Código de Processo Civil cria um sistema que privilegia a lealdade e a boa-fé processual, cujo objetivo é coibir a adoção de práticas abusivas porventura existentes no manejo e na condução da demanda. Há, assim, regras específicas sobre o dever de probidade das partes processuais (artigos 14, 17 e 18 do Código de Processo Civil). Em que pese, na atualidade, haver um arcabouço normativo próprio para coibir as práticas abusivas em âmbito jurisdicional, fato é que ele não esgota todas as possibilidades em tal pode ocorrer. ${ }^{409}$

(Ilícitos atípicos: sobre el abuso del derecho, el fraude de ley y la desviación de poder. Madrid: Editorial Trotta, 2000, p. 65-66).

${ }^{407}$ O exemplo é mencionado por Gustavo TePedino, Heloísa Helena Barboza e Maria Celina BodiN DE MORAES, que fazem referência a julgado do Tribunal de Justiça do Estado de São Paulo (Código Civil interpretado conforme a Constituição da República. Ob. cit., p. 347).

${ }^{408}$ Nesse sentido, o Código de Processo Civil estabelece multa para a hipótese de interposição de recurso manifestamente infundado e condiciona o recebimento de novos recursos ao depósito prévio dessa multa. Recentemente, o Supremo Tribunal Federal entendeu que a regra é de observância obrigatória, sob pena de os recursos posteriores não serem conhecidos. Ao fazê-lo, consignou que "O processo não pode ser manipulado para viabilizar o abuso de direito, pois essa é uma idéia que se revela frontalmente contrária ao dever de probidade que se impõe à observância das partes. O litigante de má-fé - trate-se de parte pública ou de parte privada - deve ter a sua conduta sumariamente repelida pela atuação jurisdicional dos juízes e dos tribunais, que não podem tolerar o abuso processual como prática descaracterizadora da essência ética do processo." (Supremo Tribunal Federal, Tribunal Pleno, Embargos de declaração nos Embargos de Divergência nos Embargos de Declaração no Agravo Regimental no Agravo de Instrumento ${ }^{\circ}$ 567.171, Relator Ministro CELSO DE MELLO, DJe 05.02.2009).

${ }^{409}$ Sobre o tema, ÁlVARO VILLAÇA AZEVEDo esclarece que "[n]as hipóteses do art. 17 (...) está clara a atuação ou omissão voluntária, com o objetivo de causar dano, o que se configura como ato ilícito, conforme programado no art. 185 do novo Código Civil" (Código Civil Comentado. vol. II, São Paulo: Atlas, 2003, p. 364). Assim, o problema está em saber se, ao lado dessas infrações, há espaço para se cogitar do cometimento de eventual abuso do direito de demandar. A indagação é relevante porque, embora seja 
MenEzes CoRDEIRO, fazendo referência ao art. $334^{\circ}$ do Código Civil Português- em tudo similar ao art. 187 do Código Civil Brasileiro ${ }^{410}$ - destaca que "Do enunciado, por dedução, retira-se que a boa fé e os bons costumes impõem, ou podem impor, limites ao exercício dos direitos e que estes têm, ou podem ter, um fím social e económico o qual, por seu turno, limita também, ou pode limitar, o seu exercício". 411 Assim, e nos termos da regra positiva, abusa no exercício do direito subjetivo aquele que excede manifestamente os limites impostos ( $i$ ) pelo fim econômico e social do direito exercido; (ii) pela boa-fé; e (iii) pelos bons costumes.

Se, por um lado, aquele que demanda em juízo tem em favor de si a presunção de que está a respeitar os bons costumes e a agir de acordo com a boa fé subjetiva $^{412}$, também não deve olvidar que tem de observar os deveres que decorrem da boa-fé objetiva. ${ }^{413}$ Por outro lado, o direito de demandar em juízo tem como fim precípuo a obtenção da tutela jurisdicional. Se as condutas são empreendidas com vistas a fins diversos (o uso estratégico do processo em que o fim último da parte não é a tutela jurisdicional, mas a criação de benefícios e prejuízos que decorrem da mera pendência do processo) ou em ostensiva contrariedade a esse fim (implementação de condutas que impedem e postergam injustificadamente a tutela jurisdicional), é possível se cogitar da

corrente admitir a possibilidade de ocorrência de abuso no exercício da demanda, fato é que, muitas vezes, ele é identificado com as infrações tipificadas pelo Código de Processo Civil (ver, a respeito, ÁlVARO Villaça Azevedo, Código Civil Comentado. Ob. cit., p. 364) e, então, não seriam hipóteses próprias de abuso de direito, mas de prática de condutas proibidas a priori (e, conseqüentemente, cometimento de ato ilícito propriamente dito). De toda a forma, a indagação parece já ter sido respondida pelas considerações anteriores. O direito de demandar em juízo - faceta do direito de petição - envolve um direito subjetivo público. Além das hipóteses de violação das normas que regulamentam o seu exercício (tais como os deveres estabelecidos no Código de Processo Civil), pode haver ocasião em que a conduta inicialmente fundada no exercício do direito subjetivo de demandar acabe por se revelar abusiva. Como já afirmava JORGE AMERICANO, "Com effeito, si o abuso no exercicio de qualquer direito acarreta a responsabilidade, mais rigorosa deve ser a sua constatação quando converte o proprio poder judiciario em instrumento de opressão, de perseguições individuaes, para satisfazer ambições ou interesses menos legítimos." (Do abuso do direito no exercício da demanda. $2^{\mathrm{a}}$ ed., São Paulo: Livraria Acadêmica, 1932, p. 52). Portanto, a dificuldade é menos a de se admitir a possibilidade de haver genuíno abuso de direito no exercício da demanda e mais a de encontrar critérios que permitam a sua identificação.

${ }^{410} \mathrm{O}$ art. 187 do Código Civil Brasileiro dispõe que "Também comete ato ilícito o titular de um direito que, ao exercê-lo, excede manifestamente os limites impostos pelo seu fim econômico ou social, pela boa-fé ou pelos bons costumes". A seu tempo, o art. $334^{\circ}$ do Código Civil Português consigna "É ilegítimo o exercício de um direito, quando o titular exceda manifestamente os limites impostos pela boa fé, pelos bons costumes ou pelo fim social ou económico desse direito"

411 Da boa fé no Direito Civil, Ob. cit., p. 661.

${ }^{412}$ Nas palavras de JORGE AMERICANO, “A presumpção é que age de bôa fé quem invoca o poder judiciario para dirimir uma controvérsia ou restaurar uma violação” (Do abuso do direito no exercício da demanda, Ob. cit., p. 52).

${ }^{413}$ Segundo JUDITH MARTINS-COSTA, a boa-fé objetiva impõe não só deveres instrumentais para as partes que assumem os pólos de uma relação jurídica, mas também implica limitações ao exercício de direitos subjetivos (A boa-fé no Direito Privado: sistema e tópica no processo obrigacional. São Paulo: Revista dos Tribunais, 2000, p. 437-472). 
eventual ocorrência de abuso de direito. Note-se que não é mero julgamento contrário aos interesses do litigante que permite concluir pela ocorrência de abuso de direito, mas a evidência de que se valeu do processo para fins diversos da obtenção da tutela jurisdicional. $^{414}$

A relevância da teoria aqui exposta está em que eventual utilização abusiva do processo administrativo pode ser coibida por meio dessa figura. Assim, mesmo que se entenda que o Código de Processo Civil não é aplicável subsidiariamente à Lei de Processo Administrativo (Lei n. ${ }^{\circ}$ 9.784/99) ou às leis específicas de criação das agências reguladoras - e, então, as regras que tipificam infrações processuais não poderiam ser invocadas no bojo de processos administrativos ${ }^{415}$-, os eventuais abusos poderiam ser afastados na hipótese de configurarem espécie de abuso do direito de demandar.

Note-se que, no direito brasileiro, o abuso de direito configura a prática de ato ilícito. É, pois, causa de ilicitude (e não de nulidade). Assim, a sua contribuição para minimizar o problema da captura não envolve o controle da decisão administrativa, mas a responsabilização daquele que incorreu no abuso e o desincentivo para os demais agentes econômicos que daí possa derivar.

\footnotetext{
${ }^{414}$ Nesse sentido, o Superior Tribunal de Justiça reconheceu que "Age em fraude à lei, quando exercendo uma seqüência de atos lícitos obtém resultado contrário ao preceito jurídico" (STJ, $1^{\text {a }}$ Turma, Recurso Especial 207.484, Relator Ministro Humberto Gomes de Barros, Revista do STJ vol.135, Brasília, novembro 2000, p. 136-139).O caso concreto tem origem em discussão entre a Companhia de Saneamento Básico do Estado de São Paulo - SABESP e a Companhia de Saneamento de Diadema - Saed. As partes tinham encerrado litígio anterior por meio de transação homologada judicialmente. Como a Saed não cumpriu o acordado, a Sabesp propôs a execução do título judicial. Depois de citada na execução, a Saed propôs ação anulatória do acordo, com pedido de tutela antecipada para suspender o andamento da execução. O pedido foi acolhido pelo Juízo de $1^{\circ}$ grau e mantido pelo Tribunal de Justiça. Porém, a decisão foi reformada pelo STJ ao argumento de que, embora o ordenamento jurídico admita o ajuizamento de ação para anular acordos, no caso concreto, a demanda foi utilizada pela Saed para obter a suspensão da execução sem arcar com ônus que o ordenamento jurídico impõe a quem pretende obter tais efeitos (à época, nomeação de bens à penhora e apresentação de embargos à execução no prazo fixado em lei).

${ }^{415}$ Nas hipóteses em que a lei que disciplina o processo administrativo - seja a Lei Federal de Processo Administrativo, seja a lei específica de cada agência reguladora -não previr a aplicação subsidiária do Código de Processo Civil, entende-se que o regramento do CPC quanto a deveres processuais (art. 14) poderia ser aplicado analogicamente ao processo administrativo (inclusive em eventual complemento ao art. $4^{\circ}$ da Lei de Processo Administrativo). Porém, o mesmo não se entende quanto à tipificação da litigância de má-fé e a sua punição (arts. 17 e 18). Se não houver previsão expressa de condutas que configurem a litigância de má-fé nos referidos diplomas legais ou, ao menos, o estabelecimento da aplicação subsidiária do CPC, entende-se que admitir a aplicação direta da legislação processual civil envolveria a criação, por analogia, de infração e respectiva sanção administrativas, o que não poderia ser admitido. A respeito dos limites do uso da analogia nas infrações administrativas, ver RAFAEL MunHOZ DE MELlo, Princípios constitucionais de Direito Administrativo Sancionador: as sanções administrativas à luz da Constituição Federal de 1988. São Paulo: Malheiros, 2007, p. 149.
} 


\section{b) A figura da sham exception}

Ao lado do abuso de direito de demandar em geral, é possível que a conduta empreendida pelos grupos de interesse implique efeitos anticoncorrenciais. É possível, ainda, que os regulados pretendam utilizar a regulação para gerar esses efeitos, aproximando a questão do problema da captura. Daí haver pertinência em se examinar de que modo esse tema é tratado doutrinariamente e de que modo pode auxiliar no exame do problema analisado neste trabalho.

Nesse sentido, poder-se-ia cogitar da aplicação da exceção criada no bojo da doutrina Noerr-Pennington. Essa doutrina surge nos julgamentos dos casos Eastern Railroad Presidents Conference v. Noerr Motor Freight (Noerr, 1961) e United Mine Workers of America v. Pennington (Pennington, 1965) pela Suprema Corte NorteAmericana. Os casos envolviam a contraposição entre o exercício do direito de petição e a proteção da concorrência. No primeiro deles, a situação de fato relacionava-se a pedido formulado pela indústria ferroviária ao Poder Legislativo da Pensilvânia, visando impossibilitar que o transporte rodoviário concorresse com o ferroviário em rotas de longa distância. $^{416}$ Esse pedido foi acompanhado por intensas campanhas com vistas a demonstrar as desvantagens e os prejuízos causados pelo transporte rodoviário. ${ }^{417}$ Isso gerou o litígio judicial entre representantes dos dois setores econômicos e a Suprema Corte entendeu que o direito de petição é expressão das liberdades previstas na Primeira Emenda da Constituição Norte-Americana, de molde que teria precedência sobre a proteção da concorrência prevista no Sherman Act. No segundo, a doutrina foi aplicada a uma questão que envolvia influência exercida perante o Poder Executivo. O caso discutia a legalidade de acordo firmado entre produtores de carvão e sindicatos de empregados do setor. A tratativa previa atuação em duas frentes. Por um lado, pretendia influenciar a autoridade administrativa (Secretary of Labor) para aumentar o salário mínimo dos empregados do setor. Por outro, convenceu-se a TVA (Tennessee Valley Autority) a vetar a aquisição de

\footnotetext{
${ }^{416}$ Milton Handler e Richard A. De Sevo. "The Noerr doctrine and its sham exception". Cardozo Law Review. vol. 6 (2), 1984-1985, p. 3.

417 Segundo relata GARY MiNDA, as campanhas não eram meramente publicitárias. Houve a contratação de uma empresa de relações públicas, a Carl Byoir \& Associates, que "experienced in the art of manipulating public opinion for industry, created an antitruck lobbing 'kit' - a composite of statistical information, magazine articles, films, and other sources containing half-truths, distortions and falsehoods about the trucking industry. This 'kit' then was utilized in conjunction with a media campaign in a number of key states to generate hostile public reactions against the trucking industry, and to create demand for antitruck legislation". ("Interest groups, political freedom, and antistrust: a modern reassessment of the NoerrPennington Doctrine”. Hastings Law Journal. vol. 41, 1989-1990, p. 915-916).
} 
insumos advindos de produtores que não pagassem o salário mínimo a seus empregados. A Suprema Corte não censurou a conduta adotada, mesmo diante da afirmação de que esse acordo fazia parte de uma estratégia mais ampla para excluir do mercado os pequenos produtores de carvão. ${ }^{418}$

Ocorre que, ao lado do privilégio do direito de petição, ainda no caso Noerr, a Suprema Corte ressalvou que "There may be situations in which a publicity campaign, ostensibly directed toward influencing governamental action, is a mere sham to cover what is actually nothing more than an attempt to interfere directly with the business relationships of a competitor and the application of the Sherman Act would be justified. ${ }^{, 419}$ Portanto, e tal como afirma Milton HANDler e Richard A. De SEVo, é necessário diferenciar as situações em que o peticionário atua na defesa genuína de um interesse ou direito próprio daquelas em que utiliza o pedido para, diretamente, gerar um resultado anticoncorrencial. ${ }^{420}$ No primeiro caso, o peticionário está no exercício de seu direito de petição (mesmo que tenha empreendido condutas desleais ou antiéticas). ${ }^{421}$ No segundo, está-se diante da sham exception, conduta abusiva que não deve ser admitida em face do direito antitruste.

Em que pese a dificuldade de se estabelecer critérios que permitam diferenciar com precisão as duas situações, a Suprema Corte julgou caso (California Motors Transports Co. vs. Trucking Unlimited, 1972) em que considerou que a conduta dos peticionários se incluía na exceção da doutrina Noerr-Pennington. A controvérsia envolvia discussão entre transportadoras locais e interestaduais. Segundo as empresas locais, em todos os pedidos que formulavam na tentativa de expandir as rotas em que

\footnotetext{
${ }^{418}$ Essa estratégia mais ampla é narrada por GARY MINDA. Segundo o AUTOR, em 1950, grandes produtores de carvão e os sindicatos do setor entendiam que o maior problema da indústria era uma suposta superprodução. Para resolvê-lo, os sindicatos concordavam que esses grandes produtores substituíssem mãode-obra por maquinário (labor-saving technology) e, portanto, reduzissem o número de empregos, desde que houvesse um aumento dos salários dos empregados remanescentes. O problema é que esse salário maior foi imposto como regra e prejudicou intensamente os pequenos produtores. Se era fato que os grandes produtores absorveram esse aumento do custo de produção utilizando novas tecnologias que reduziam a necessidade de empregados, os pequenos produtores - que necessitavam de um volume considerável de mão-de-obra ficavam alijados do mercado em virtude do aumento do custo de produção. De acordo com G. MiNDA, "The 1950 wage agreement established a classic 'barriers to entry' - a device economists consider essential to successfully secure a monopoly advantage" ("Interest groups, political freedom, and antistrust: a modern reassessment of the Noerr-Pennington Doctrine". Ob. cit., p. 925).

${ }^{419}$ A citação foi extraída do texto de THOMAS A. BALMER, "Sham litigation and the antitrust laws". Buffalo Law Review. vol. 29, 1980, p. 41-42.

420 "The Noerr doctrine and its sham exception". Ob. cit., p. 8.

${ }^{421}$ Nessa situação, caso condutas desleais ou antiéticas sejam empreendidas, elas deverão ser sancionadas pelas regras específicas (no direito anglo-saxão envolveria situações de tort law, cujos parâmetros seriam fixados pela common law). Porém, não podem ser afastadas por contraste com a legislação antitruste.
} 
atuavam (tanto perante a agência reguladora local, quanto perante a agência reguladora federal), as transportadoras interestaduais intervinham "with and without problable cause, and regardless for the merits of the cases". ${ }^{422}$ Nesse caso, a Suprema Corte entendeu que se estava diante da sham exception, pois as empresas locais tiveram inviabilizado o acesso às agências reguladoras e, mesmo, ao Judiciário. ${ }^{423}$ A questão, no entanto, permanecia sem solução. Em que pese reconhecer, casuisticamente, que a situação envolvia uma sham exception, não foram estabelecidos critérios para diferenciar o exercício legítimo do direito de petição e o eventual abuso que gera efeitos anticompetitivos. ${ }^{424}$

Em 1993, ao decidir o caso Professional Real Estate Investors, Inc. v. Columbia Pictures Industries, Inc., a Suprema Corte definiu um teste com vistas a diferenciar essas situações (denominado PRE test). ${ }^{425}$ Esse teste se desdobraria em duas

${ }^{422} \mathrm{O}$ trecho da decisão é mencionado no relatório do Federal Trade Commission denominado "Enforcement perspectives on the Noerr-Pennington Doctrine: na FTC Staff Report", 2006, p. 7 (Disponível em: http://www.ftc.gov/reports/P013518enfperspectNoerr-Penningtondoctrine.pdf. Último acesso em: 20.06.2009). Além do reconhecimento concreto de uma sham exception, o caso California Motors é relevante para a própria evolução da doutrina Noerr-Pennington. Nele, entendeu-se que a referida doutrina seria aplicável não só a situações que envolvessem atividade normativa, mas também em casos de adjudicação (tanto do Poder Judiciário, quanto da Administração Pública). Assim, e conforme afirmam MILTON HANDLER e RichARD A. DE SEVo, nesse caso firma-se o entendimento de que "the right to petition extends to all departments of all Government" ("The Noerr doctrine and its sham exception". Ob. cit., p. 6). Esse julgado, lido em conjunto com a decisão do caso Allied Tube \& Conduit Corp. v. Indian Head, Inc, torna claro o âmbito de incidência do doutrina. No caso Allied Tube, ficou estabelecido que a doutrina Noerr-Penngington não se aplica a pedidos formulados fora da órbita estatal, ainda que em tal esfera possa haver algum tipo de exercício de atividade normativa. O caso envolvia petições dirigidas a uma associação privada responsável pela criação de normas técnicas para a regulamentação de produtos. Nesse caso, "The Court held that the association was not a quase-legislative body because it had no official authority and its decision-making body was composed, at least in part, of those with economic incentives to restrain trade. Therefore, the defendant could not claim Noerr protection for lobbying the private standard-setting association" ("Enforcement perspectives on the Noerr-Pennington Doctrine: an FTC Staff Report”, Ob. cit., p. 8). Em resumo: as petições dirigidas a órgãos do Legislativo, do Executivo e do Judiciário admitem, em princípio, a proteção da doutrina Noerr-Pennington, seja em relação à atividade normativa, seja em relação à atividade adjudicatória. Os pleitos formulados perante pessoas privadas, ainda que essas exerçam alguma espécie de competência normativa, não podem invocar a referida doutrina.

${ }^{423}$ GARY MINDA sustenta que o tratamento mais rigoroso aplicado no caso California Motors deriva do fato de se estar diante de atividade adjudicatória (e não normativa). De acordo com o AUTOR, "Unethical conduct condoned in the political arena was not immunized in the adjudicatory process. Hence, petitions before adjudicatory bodies were entitled to a different (lower) degree of immunity protection than that afforded petitions before legislative bodies" ("Interest groups, political freedom, and antistrust: a modern reassessment of the Noerr-Pennington Doctrine". Ob. cit., p. 929).

${ }^{424}$ GARY MINDA chega a afirmar que, nesse contexto, nenhuma conduta se enquadraria na sham exception. Segundo o AUTOR, se a exceção só é aplicada nos casos em que o direito de petição é empregado sem uma intenção genuína de influenciar a ação governamental, ela é uma exceção que não faz sentido. Ainda de acordo com G. MiNDA, seria evidente que uma grupo de produtores que busca restringir a atuação de seus competidores por meio da regulação sempre está buscando influenciar, genuinamente, a atuação estatal. Afinal, "What better way to eliminate competition then by having the government impose a barrier to competition for rivals?" ("Interest groups, political freedom, and antistrust: a modern reassessment of the Noerr-Pennington Doctrine”. Ob. cit., p. 923).

425 Note-se que antes de a Suprema Corte estabelecer um teste que permitisse diferenciar, com maior objetividade, as situações de abuso e aquelas que não o configuravam, houve quem tentasse buscar esses 
partes. A primeira envolveria verificar se o pleito é objetivamente infundado, no sentido de que nenhum litigante razoável esperaria ter êxito no mérito da demanda. Se verificada essa característica, aplicar-se-ia a segunda parte do teste, que consistiria em investigar se o pleito reflete a intenção de o agente econômico utilizar o aparelho estatal como ferramenta anticompetitiva para interferir diretamente nas relações empresariais dos concorrentes. ${ }^{426}$ Se, porém, o teste razoavelmente resolve o exame de casos únicos, ele não é suficiente para solucionar questões como a enfrentada no caso California Motors, em que a conduta adotada pelos agentes econômicos foi a de propor intensa e repetidamente demandas contra os concorrentes. Para essas situações, a jurisprudência norte-americana (no caso USSPosco do nono circuito, e posteriormente, no caso Primetime 24, do segundo circuito) entendeu que nas situações em que os agentes recorrem à formulação de uma série de pedidos, a questão não é de investigar se cada um desses pleitos é plausível, mas de considerar a conduta como um todo (se ela é empreendida sem considerar a obtenção de eventuais êxitos e com vistas a promover prejuízos e dificuldades para os concorrentes). Portanto, para as demandas repetitivas, o exame deixaria de ser retrospectivo (como o é no PRE-Test) e deveria ser prospectivo. ${ }^{427}$

Assim, da jurisprudência norte-americana, é possível retirar dois critérios para aferir a abusividade do direito de petição sob o ângulo concorrencial. Primeiro, o PRE-Test e os dois passos por ele previstos. Depois, o exame das demandas repetitivas como uma conduta que, por ela mesma, pode gerar um resultado anticoncorrencial. A Federal Trade Comission, no entanto, sustenta que a sham exception pode ser ampliada para abranger não só as situações que passem pelo "PRE-Test" e que configurem o "peticionamento repetitivo" com as características acima mencionadas, mas também outras duas: (i) as situações em que, menos que apresentar uma petição para tentar influenciar o exercício de discricionariedade das autoridades estatais, o pleito resume-se a registrar uma informação com vistas a obter um "ato vinculado" com impacto sobre a concorrência; (ii)

critérios em decisões da Suprema Corte que não tratavam, diretamente, de conflitos entre concorrentes. Nesse sentido, Milton Handler e Richard A. DE SEvo defendiam que as bases para a aplicação da sham exception poderiam ser encontradas no caso Bill Johnson's Restaurants, Inc.v. NLRB. A partir de tais parâmetros, para se saber se a demanda se encaixa (ou não) na exceção, dever-se-ia examinar um "dual standard of baselessness as articulated in Bill Jonhson's Restaurants: only an attempt to petition the government that is plainly foreclosed as a matter of law or is otherwise frivolous, and which the petitioner instigated knowing that it lacked any factual or legal basis, should subject the defendant to antitrust liability" ("The Noerr doctrine and its sham exception". Ob. cit., p. 55).

${ }^{426}$ Federal Trade Commission, "Enforcement perspectives on the Noerr-Pennington Doctrine: an FTC Staff Report", Ob. cit., p. 11-12.

${ }^{427}$ Federal Trade Commission, "Enforcement perspectives on the Noerr-Pennington Doctrine: an FTC Staff Report”, Ob. cit., p. 32. 
as situações em que a apresentação das circunstâncias (fáticas e jurídicas) é feita de modo deturpado ou omisso, que acaba por induzir em erro o responsável pela tomada da decisão. ${ }^{428}$

Para justificar a primeira situação, a Federal Trade Commission defende que o direito de petição, por sua natureza, dirige-se à obtenção de uma ação governamental. Porém, há ocasiões em que os agentes se dirigem aos órgãos estatais apenas para registrar dadas informações, com vistas a obter mera chancela governamental. Em tais casos, em que não haja a expressão de opinião política e nem pedido que implique o exercício de competências discricionárias, a conduta requerida dos entes estatais é meramente passiva e pedidos dirigidos à obtenção desses atos não estariam protegidos pela doutrina Noerr-Pennington. ${ }^{429}$

Na segunda situação, entende-se que no contexto político é pouco provável conseguir estabelecer uma relação causal entre eventual pedido apresentado e a norma efetivamente editada. Porém, fora dele, a atuação das autoridades públicas é mais bem delimitada e identificação dessa relação "causa e efeito" torna-se mais plausível. Assim, e fora do âmbito político, é possível que se afaste a aplicação da doutrina Noerr-Pennington quando a apresentação deturpada ou omissiva das circunstâncias fáticas e jurídicas seja $(i)$ deliberada (deve haver algo mais que mero erro); (ii) passível de se submeter a verificações

\footnotetext{
${ }^{428}$ Rigorosamente, o relatório da Federal Trade Comission faz alusão a três novas situações que permitiriam exceptuar a doutrina Noerr-Pennington. Além das duas mencionadas, faz referência ao "peticionamento repetitivo". Esse conjunto pode ser considerado como exceções autônomas que, ao lado do sham litigation passível de ser identificada pelo PRE-Test, não permitem invocar a doutrina Noerr-Pennington para obter a imunidade antitruste (Federal Trade Commission, "Enforcement perspectives on the Noerr-Pennington Doctrine: an FTC Staff Report", Ob. cit., p. 1-38).

${ }^{429}$ Apenas para ilustrar, mencione-se o caso referido pela Federal Trade Comission acerca do ingresso de fabricantes de medicamentos genéricos na indústria farmacêutica. De acordo com as normas estabelecidas, a Food and Drug Administration (FDA) registrava as patentes existentes dos "medicamentos de marca" no denominado "Orange Book" (essa atividade envolvia o mero registro, sem qualquer análise da origem das patentes). Para que se pudesse obter a autorização para produzir um medicamente genérico, era necessário que o interessado demonstrasse que o medicamento que pretende produzir não está registrado no Orange Book. Um grupo de fabricantes de medicamentos genéricos acusou a Bristol-Myers Squibb de ter apresentado ao FDA patentes obtidas fraudulentamente. Elas foram incluídas no Orange Book, o que gerou um atraso de 30 meses na obtenção da autorização para o início da produção dos genéricos que concorreriam com a Bristol-Myers Squibb. O Federal Trade Commission entendeu que uma situação como essa - em que a FDA limitava-se a registrar as patentes - o pedido de inclusão dessas informações no Orange Book não estava protegido pela doutrina Noerr-Pennington. Afinal, naquele contexto, a FDA não podia exercer qualquer competência discricionária, assim como não havia qualquer teor político no pedido formulado (Federal Trade Commission, "Enforcement perspectives on the Noerr-Pennington Doctrine: an FTC Staff Report", Ob. cit., p. 4-5).
} 
fáticas; e (iii) central para a ação governamental (governmental proceeding) em questão. ${ }^{430}$

Em resumo: a sham exception, apta a admitir a aplicação do direito antitruste, envolveria a sham litigation (pedido desprovido de embasamento detectado pelo PRE-Test), a apresentação reiterada de pedidos administrativos e judiciais com objetivos anticoncorrenciais; os pedidos destinados a provocar atos vinculados, quando a prática deles é tomada como instrumento para obtenção de um resultado anticoncorrencial; e os pedidos que induzem deliberadamente em erro o responsável pela tomada da decisão (seja em virtude de apresentação deturpada dos fatos e argumentos jurídicos, seja em decorrência de omissões nessa narrativa).

No Brasil, o Sistema Brasileiro de Defesa da Concorrência - SBDC acena para a possibilidade de vir a aplicar a sham exception, seja em decorrência da apresentação de pleitos judiciais, seja pelo uso de pedidos administrativos.

Relativamente a pleitos judiciais, merece destaque a Averiguação Preliminar $n^{\circ} 08012.005335 / 2002-67^{431}$. Nela, admitiu-se a instauração de processo administrativo para apuração de prática abusiva levada a efeito no mercado de publicações de passatempos. Há a fundada suspeita de que o agente econômico que efetivamente detinha poder de mercado ajuizava demandas judiciais para tentar bloquear o ingresso de novos agentes ou impedir o desenvolvimento dos concorrentes. ${ }^{432}$ Além desse, há o Processo Administrativo $\mathrm{n}^{\mathrm{o}}$ 08012.004484/2005-51, em que a Secretaria de Direito Econômico recomendou a condenação de agente econômico que teria empreendido a prática de sham litigation. $^{433}$ No caso concreto, ter-se-ia aproveitado uma suposta divergência entre as regras técnicas editadas pelo Instituto Nacional de Metrologia, Normalização e Qualidade Industrial - Inmetro e aquelas editadas pelo Departamento Nacional de Trânsito-Denatran

\footnotetext{
${ }^{430}$ Federal Trade Commission, "Enforcement perspectives on the Noerr-Pennington Doctrine: an FTC Staff Report”, Ob. cit., p. 27-28.

431 Conselho Administrativo de Defesa Econômica. Averiguação Preliminar no 08012.005335/2002-67. Relator Conselheiro LUÍs FERNANDO SCHUARTZ, DOU 2.5.2007.

$432 \mathrm{O}$ voto do Conselheiro LUIZ FERNANDO SCHUARTZ cita alguns acordos para encerramento de demandas judiciais firmados nos feitos ajuizados pela Editora Ediouro (agente com posição dominante no mercado) contra alguns de seus concorrentes. Conforme o estabelecido nesses acordos, a Editora Ediouro passava a publicar as revistas então publicadas pelas concorrentes (que, assim, saíam do mercado). Em contrapartida, pagava a esses concorrentes quantias em dinheiro com vistas a reembolsar as despesas e os prejuízos decorrentes do processo judicial. Em que pese o título do pagamento (reembolso de despesas e ressarcimento de prejuízos), os valores previstos eram muito significativos e, em alguns casos, implicavam pagamentos contínuos, sem previsão de termo final (p. 3 e 4).

433 Conselho Administrativo de Defesa Econômica. Processo n ${ }^{\circ}$ 08012.004484/2005-51, Relator Conselheiro FERnANDo DE MAGALHÃES FURLAN.
} 
para tentar afastar (ou, ao menos, postergar), por meio do ajuizamento de medida judicial, o ingresso de produto concorrente que utiliza outra tecnologia. ${ }^{434}$

Quanto aos pedidos administrativos, ambos envolvem mercados regulados.

O primeiro diz respeito à Averiguação Preliminar $n^{\circ}$ 08012.005610/2000$81^{435}$, relativo a uma controvérsia sobre transporte de passageiros. Por meio de autorização do órgão regulador estadual, empresa responsável por transporte intermunicipal (Viação Oliveira Torres) passaria a fazer concorrência parcial com uma empresa de transporte municipal (Empresa Valadrense de Transporte Coletivo). A empresa municipal passou, então, a adotar diversas medidas contra essa autorização (administrativa e judicialmente), bem como a, supostamente, exercer a influência que detém perante o órgão municipal com vistas a prejudicar os pedidos formulados pela empresa intermunicipal. O voto-vista do Conselheiro PAUlo FurquiM, depois de ponderar sobre a relevância constitucional do direito de petição, menciona que "seu uso indiscriminado e com fundamentos inconsistentes, como transparece em algumas passagens dos autos, pode configurar abuso de direito e infração à ordem econômica, se restar configurado ser seu propósito primeiro obstruir a concorrência". ${ }^{436}$ Assim, admitiu-se a instalação de processo administrativo para apurar a ocorrência de prática abusiva.

O segundo (Averiguação Preliminar $n^{\circ}$ 08012.006076/2003-72 ${ }^{437}$ ) diz respeito a julgamento de recurso de ofício em averiguação preliminar relativa à denúncia apresentada pelo Grupo Moura contra um conjunto de empresas que produzem baterias estacionárias (e que detêm 90\% do mercado). Segundo o Grupo Moura, o conjunto de empresas havia atuado de modo concertado ao solicitar esclarecimentos perante a ANATEL relativamente à certificação das baterias por si produzidas. Ainda segundo o

\footnotetext{
${ }^{434}$ Trata-se do caso dos tacógrafos, em que a atuação da Representada (Siemens VDO Automotive Ltda.) teria envolvido a conjugação de duas medidas. Por um lado, o uso de demandas judiciais para dificultar o ingresso de nova tecnologia no mercado (Parecer da Secretaria de Direito Econômico no Processo Administrativo 08012.004484/2005-51, Seva Engenharia Eletrônica S.A. vs. Siemens VDO Automotive Ltda., p.48). Por outro, teria ocorrido convite à Representante (SEVA Engenharia Eletrônica S.A.) para participar de cartel. Com a atuação nessas duas frentes, a Siemens evitaria a disseminação da nova tecnologia no Brasil e, portanto, evitaria a concorrência no mercado de tacógrafos, no qual exerce posição dominante. O caso conta com o parecer da Secretaria de Direito Econômico - SDE que opina pela condenação, mas ainda não foi julgado pelo Conselho Administrativo de Defesa Econômica - CADE.

${ }^{435}$ Conselho Administrativo de Defesa Econômica. Averiguação Preliminar n ${ }^{\circ}$ 08012.005610/2000-81, Relator Conselheiro LUÍS FERNANDO SCHUARTZ, DOU 18.9.2006.

436 Conselho Administrativo de Defesa Econômica, Averiguação Preliminar nº 08012.005610/2000-81, Voto-vista do Conselheiro PAUlo FURQUim DE AZEVEDo, p. 5.

${ }^{437}$ Conselho Administrativo de Defesa Econômica, Averiguação Preliminar no 08012.006076/2003-72, Relator Conselheiro CARLOS THADEU DELORME PRADO, DOU 17.07.2007.
} 
Grupo Moura, essa conduta visava excluí-lo do mercado, especialmente porque os bens por si produzidos eram comercializados por preços significativamente menores que os praticados pelo conjunto de empresas. $\mathrm{O}$ arquivamento recomendado pela Secretaria de Direito Econômico foi mantido, já que a ANATEL efetivamente detectou irregularidades no procedimento de certificação do produto fabricado pelo Grupo Moura e, mesmo assim, manteve a homologação do produto por entender que não havia parâmetros técnicos atualizados para a área. O relevante desse caso é o fato de que o Conselheiro RICARDO VILLAS BÔAS CUEVA teceu diversas considerações quanto à doutrina Noerr-Pennington e à exceção que a ela se aplica. Aparentemente, entende possível que esses parâmetros venham a ser aplicados no âmbito do Sistema Brasileiro de Defesa da Concorrência.

Por fim, o único caso em que houve condenação por infração à ordem econômica envolveu conjunto de pedidos dirigidos ao Poder Executivo e ao Poder Legislativo. No Processo Administrativo $n^{\circ} 08000.024581 / 1994-77^{438}$, apurou-se que o Sindicato do Comércio de Varejista de Derivados de Petróleo do Distrito Federal (SINPETRO), a Rede Gasol e o Grupo Igrejinha empreenderam conduta anticompetitiva por meio do exercício do direito de petição. A rede de supermercados Carrefour pretendia obter autorização administrativa para instalar postos de gasolina anexos aos supermercados da rede. Os Representados formularam diversos pedidos perante o Executivo em que pleiteavam, de forma expressa, que se deixasse de atender a descabida pretensão do Carrefour. Ao Legislativo, encaminharam minuta de projeto de lei, que acabou aprovado, no qual se previa a expressa proibição de construção de postos de gasolina em pátios de hipermercados.

Como SANDRA TEREPINS já teve oportunidade de examinar em detalhes, a aplicação dos parâmetros criados pela jurisprudência norte-americana permitiria identificar que se estava, de fato, diante de uma sham exception. ${ }^{439} \mathrm{O}$ conjunto de pedidos formulados não visava à tutela de interesses dos peticionários, mas obstar, por qualquer meio, o ingresso de novo agente econômico no mercado. A conduta enquadrar-se-ia nos

\footnotetext{
${ }^{438}$ Conselho Administrativo de Defesa Econômica, Processo Administrativo $\mathrm{n}^{\mathrm{o}}$ 08000.024581/1994-77, Relator Conselheiro Roberto Augusto CASTEllanOs PFeIFFER, DOU 9.2.2005.

439 "Sham litigation - uma exceção à doutrina Noerr-Pennington e a experiência recente vivida pelo CADE". Revista do IBRAC. vol. 15 (1), 2008, p. 80-84.
} 
parâmetros criados a partir dos casos USS-Posco e Primetime 24, equivalendo às condutas censuradas no caso California Motors. ${ }^{440}$

\author{
Por certo, e como já salientou o Conselheiro LUIZ FERNANDO SCHUARTZ,
}

deve-se destacar desde logo que é muito tênue a linha divisória que separa as ações do poder público que restringem abusivamente o exercício legítimo de algum direito subjetivo (e.g. o direito de contratar ou o direito de recorrer), das ações do poder público que restringem legitimamente o exercício abusivo de algum direito subjetivo, recomendando-se o máximo de cautela para os que pretenderem transitar por essa linha. Não obstante, essa separação existe, não podendo o CADE, no seu papel de órgão judicante, furtar-se à tarefa de determinar se uma conduta ou seqüência de condutas que se apresenta como exercício legítimo de um direito é ou não abusiva no sentido específico de ter por propósito a obtenção de um dos estados de coisas referidos nos incisos do art. 20 da Lei $8.884 / 94 .^{441}$

A sham exception da doutrina Noerr-Pennington é, portanto, modo de compatibilização entre o direito de petição e a eventual afronta à concorrência que daí pode derivar. Embora tenha essa aplicação específica e estrita a questões com impacto concorrencial, presta-se a contribuir para o tratamento do problema da captura.

Primeiro, e tal como ficou evidenciado quando da exposição do problema, um dos motivos que pode gerar a captura é a busca por regulação pelos regulados. Essa procura funda-se, especialmente, na tentativa de obter medidas regulatórias que protejam os regulados da pressão concorrencial. ${ }^{442}$ Portanto, a tendência é a de que haja um número significativo de demandas perante as agências reguladoras que gerem impactos concorrenciais nos setores específicos. Isso é confirmado pelas informações contidas no texto de Milton Handler e Richard A. De Sevo, no qual se indica que grande número de casos em que se invocou a doutrina Noerr-Pennington envolveu pedidos formulados

\footnotetext{
${ }^{440}$ Em sentido contrário, EDUARDO FERREIRA JORDÃO entende que "A postura adotada pelo CADE neste caso é contrária ao entendimento da Suprema Corte americana com a Noerr-Pennington Doctrine" ("O direito antitruste e o controle do lobby por regulação restritiva da concorrência". Revista de Direito Público da Economia. vol. 25, jan-mar 2009, p. 77). Apesar de serem procedentes as críticas formuladas pelo AUTOR no sentido de que a decisão não estabeleceu parâmetros precisos para definir os limites do exercício legítimo do direito de petição, parece ser possível enquadrar a conduta implementada pelos agentes econômicos nesse caso específico dentre as exceções já desenvolvidas na doutrina norte-americana. Assim, não seria propriamente caso de proteção da doutrina Noerr-Pennington, mas situação que se encaixa em exceção à aplicação de tal doutrina. Por outro lado, a sanção antitruste aplicada não implica, necessariamente, afronta ao direito de petição. $\mathrm{O}$ direito de petição esgota-se no próprio exercício do direito e na possibilidade de exigir resposta por parte do Poder Público. Se há abuso em seu exercício, a ponto de os atos praticados poderem ser enquadrados como ilícitos antitruste, nada obsta que sejam sancionados. No caso concreto, menos que tutelar interesses próprios, os pedidos foram dirigidos para interferir diretamente nos negócios do concorrente (rede Carrefour), a fim de que o pedido por este formulado fosse denegado.

441 CADE, Averiguação Preliminar $n^{\circ}$ 08012.005335/2002-67, Relator Conselheiro LUIZ FERNANDO SCHUARTZ, p. 3, item 7.

${ }^{442}$ A respeito, ver os motivos elencados por STIGLER para a busca de regulação (item 2.1.2, supra).
} 
perante agências reguladoras (o que demonstra haver espaço para se cogitar da aplicação da sham exception). ${ }^{443}$

Assim, e em virtude dessa ordem de considerações, é plausível assumir a possibilidade de que grupos sujeitos à regulação busquem valer-se da atividade regulatória para, diretamente, gerar prejuízos aos concorrentes. ${ }^{444} \mathrm{E}$, com isso, empreenderem conduta que pode ser enquadrada na sham exception, a ser contrastada com a legislação antitruste.

Por outro lado, ao se permitir o controle antitruste que pode derivar da aplicação da sham exception, permite-se a inclusão de novas instâncias decisórias - os órgãos do sistema de proteção da concorrência - que ampliam o controle e reduzem os riscos de captura. ${ }^{445}$

\section{c) A liberdade de manifestação perante os órgãos públicos e o abuso de direito}

Por fim, o argumento que se poderia utilizar para inibir a aplicação da sham exception é, justamente, a noção subjacente à doutrina Noerr-Pennington, qual seja: não se pode inibir a manifestação de pensamento e a participação política dos cidadãos.

Se é correto afirmar que esse direito não pode ser tolhido, também parece certo dizer que esse direito não pode ser utilizado de modo abusivo e com vistas a contrariar regras jurídicas estabelecidas para a ordenação de outras searas da vida. Nesse

443 "The Noerr doctrine and its sham exception". Ob. cit., p. 20.

${ }^{444}$ Note-se que essa possibilidade se amplia quando se está diante de uma multiplicidade de instâncias regulatórias (conforme relatado acima, no caso dos tacógrafos, o agente econômico instalou discussão judicial acerca da regulamentação editada pelo órgão de trânsito; no caso da concorrência entre empresas de transportes, o agente econômico visava a contrapor a regulamentação editada pelo órgão estadual e aquela editada pelo Município). Em outras palavras: a pluralidade de instâncias é aproveitada pelos agentes econômicos, a fim de obterem o resultado que lhes seja mais favorável (há, aí, um "jogo com as regras” com vistas a obter tal resultado). Tal como afirma SABINO CASSESE, "La motiplicazione dei regulatori, sai allo stesso livello (nello Stato), sai a piú livelli (nazionale e comunitário) offre um'ulteriore occasione ai regolati, i quali sfruttano i conflitti tra le autorità per ottenere il rispetto dei loro diritti (o, comunque, provvedimenti più favoreboli)." ("Dalle regole del gioco al gioco com le regole". Ob. cit., p. 272)

445 ANA MARIA DE OLIVEIRA NUSDEO, ao examinar a separação e a articulação entre as competências das agências reguladoras e as atribuídas aos órgãos de proteção à concorrência, destaca que "a transferência de poderes exclusivos às agências é uma alternativa perigosa, tomando-se em consideração o risco de sua captura pelos interesses regulados, à medida que o contato reiterado com os agentes econômicos atuantes no setor tende a produzir uma identificação entre os interesses dessas empresas e os funcionários das agências." (“A regulação e o direito da concorrência”. In: SUNDFELD, Carlos Ari. Direito Administrativo Econômico. São Paulo: Malheiros, 2002, p. 179) A contrario sensu, extrai-se que a atuação dos órgãos de defesa da concorrência sobre os setores regulados é positiva para minimização do problema da captura, já que "retira" a exclusividade de atuação das agências reguladoras setoriais (ao menos em matéria concorrencial). Em sentido semelhante, SABINO CASSESE entende que a presença de várias autoridades com competência para decidir o mesmo caso (tal como ocorre quando se outorga competências à autoridade da concorrência para atuar em face de mercados regulados) pode levar à otimização do interesse geral que se visa a tutelar ("Dalle regole del gioco al gioco com le regole". Ob. cit., p. 272-273). 
sentido, deve-se anotar que a idéia de que pode haver abuso no exercício desse direito em geral (e que pode, especificamente, configurar a ocorrência de sham exception apta a viabilizar o contraste com o direito antitruste acima mencionado) encontra, em algum sentido, respaldo na jurisprudência do Supremo Tribunal Federal.

No HC 82.424, o Supremo Tribunal foi chamado a decidir o caso Ellwanger. O Sr. Siegfried Ellwanger foi condenado nas instâncias ordinárias pelo crime de discriminação tipificado no art. 20 da Lei n. ${ }^{\circ}$ 7.716/89 ("Praticar, induzir ou incitar a discriminação ou preconceito de raça, cor, etnia, religião ou procedência nacional"), consubstanciado na publicação de livros com conteúdo antissemita. O habeas corpus foi impetrado pelo Sr. Ellwanger com o objetivo de demonstrar que a conduta por si praticada não configurava prática de racismo e, portanto, não se sujeitava à imprescritibilidade prevista no art. $5^{\circ}$, XLII, da Constituição Federal. Ao lado de questões da mais alta indagação (como a natureza antropológica ou cultural do conceito de raça), surgiu a dúvida de se saber se a conduta praticada pelo Sr. Ellwanger não estaria albergada pela liberdade de manifestação de pensamento e de consciência, previstas no art. $5^{\circ}$, IV e IX, da Constituição Federal. O voto do Ministro CARLOS BRITTO - que restou vencido e privilegiava a liberdade de pensamento e consciência - acabou por estabelecer alguns parâmetros para que se examine a abusividade no exercício desses direitos. Em parcela do voto, posteriormente reprisada pelo voto do Ministro Sepúlveda Pertence, o Min. CARLOS BRITTO consignou:

Que a Lex Maxima declara e garante a liberdade de expressão, é juízo que ninguém desconfirma.
Liberdade tanto para manifestar o pensamento (exteriorizá-lo, portanto) como para expor o fruto
da atividade artística, intelectual, científica, ou de comunicação. Ponto pacífico. Uma coisa,
porém, é a liberdade de que desfruta quem quer seja para dizer o que quer que seja (em poema
antigo, cheguei a trocadilhar que a liberdade de expressão é a maior expressão da liberdade), ou,
ainda, para trazer à ribalta suas incursões pelos domínios da Arte, do Intelecto, da Ciência, ou da
Comunicação; outra coisa, bem diferente, é o titular dessas liberdades ficar imune a resposta por
eventual agravo a terceiros, ainda que não intencionalmente cometido. Ou, pior ainda, deixar de
responder pelos abusos em que vier a incorrer, deliberadamente. ${ }^{446}$

Assim, e para o Ministro CARlos BritTo, a Constituição garante a cada indivíduo um “espaço apriorístico de movimentação". Nesse espaço, garante-se a incontrolabilidade da manifestação de pensamento, traduzida como a impossibilidade de se impedir ou censurar previamente o exercício do direito. Porém, essa liberdade, nesse ponto tutelada de forma até mesmo absoluta, não significa autorização para que os

${ }^{446}$ Supremo Tribunal Federal, Pleno, HC 82.424, Relator Ministro MAURícIO CORRÊA, DJ 19.-3.2004 item 41 do voto do Ministro CARLOS BRITTO. 
eventuais abusos ou condutas gravosas deixem de gerar a respectiva responsabilização. Esses abusos e agravos permitem que, a posteriori, aquele que se valeu da manifestação de pensamento e causou prejuízo a outrem venha a ser responsabilizado. Trata-se, inclusive, de um mecanismo cíclico: a cada abuso ou agravo gerado pela manifestação de pensamento surge a possibilidade de que esses venham a ser apurados e constatados (com a respectiva responsabilização daquele que exerceu o direito). Ainda nas palavras do Ministro CARLOS BRITTO,

Os dois momentos de licitude são estes: a) o primeiro sujeito de direito não pode ser obstado, por antecipação, quanto à sua liberdade de manifestar ou de voltar a manifestar um pensamento, ou, ainda de desempenhar ou tornar a desempenhar aquelas outras quatro atividades (a literária, a científica, a artística e a de comunicação); b) correlatamente, o segundo sujeito de direito também não pode ser obstado em sua pretensão de punir o autor da conduta extravasante, quantas vezes o extravasamento vier a conspurcar a sua (dele, segundo sujeito de direito) autonomia de vontade. ${ }^{447}$

A esse mecanismo, agregar-se-iam três "excludentes de abusividade". Tratar-se-iam dos comportamentos ditados por imperativos de consciência previstos no art. $5^{\circ}$, VIII, da CF e que envolveriam as manifestações atinentes à (i) crença religiosa, (ii) concepção filosófica, e (iii) convicção política. Quanto à última, ressalva que

\begin{abstract}
a convicção política de que trata o Código dos Códigos é aquela que materializa o fundamento republicano-federativo de nome "pluralismo político" (inciso V do art. $1^{\circ}$ ). De conseguinte, atividade que ora se contém no fechado conteúdo programático de uma determinada agremiação partidária, ora se exprime numa concepção estritamente pessoal do modo optimum de estruturação e funcionalização da pólis (espaço ideal de materialização das primárias relações entre governados e governantes e ainda entre os próprios Estados e Governos Soberanos). ${ }^{448}$
\end{abstract}

O posicionamento ditado nesse caso acabou por ser adotado, mutatis mutandis, no julgamento de dois feitos que, recentemente, geraram repercussão significativa.

O primeiro diz respeito à não-recepção da Lei de Imprensa pela Constituição de 1988. Embora o acórdão final do caso ainda não haja sido disponibilizado pelo Supremo Tribunal Federal, as notícias veiculadas por aquele Tribunal dão conta de que o entendimento adotado foi no sentido de que a Constituição da República fixou "a precedência das liberdades de pensamento e de expressão lato sensu as quais não poderiam sofrer antecipado controle nem mesmo por força do Direito-lei (...)". ${ }^{449}$ Todavia, a

\footnotetext{
${ }^{447}$ Supremo Tribunal Federal, Pleno, HC 82.424, Relator Ministro MAURícIO CORRÊA, DJ 19.-3.2004 item 48 do voto do Ministro CARLOS BRITTO.

${ }^{448}$ Supremo Tribunal Federal, Pleno, HC 82.424, Relator Ministro MAURí́cIo CoRrÊA, DJ 19.3.2004 item 50 do voto do Ministro CARLOS BRITTO.

${ }^{449}$ STF, ADPF 130/DF, rel. Min. Carlos Britto, j. 30.4.2009 (Notícia: “ADPF e Lei de Imprensa - 8”, Informativo $\mathrm{n}^{\circ}$ 544).
} 
impossibilidade de controle preventivo das manifestações relacionadas à liberdade de expressão e de pensamento não vedam que haja responsabilização a posteriori, inclusive por meio do ajuizamento de eventual ação penal que se afigure cabível. ${ }^{450}$

O segundo caso envolveu o julgamento quanto à exigência de diploma para o exercício da profissão de jornalista. A íntegra do acórdão ainda não foi disponibilizada ao público. De toda a forma, também aqui, as notícias veiculadas pelo STF destacam que, naquele julgamento,

Entendeu-se ser certo que o exercício abusivo do jornalismo ensejaria graves danos individuais
e coletivos, mas que seria mais certo ainda que os danos causados pela atividade jornalística
não poderiam ser evitados ou controlados por qualquer tipo de medida estatal de índole
preventiva. Dessa forma, o abuso da liberdade de expressão não poderia ser objeto de controle
prévio, mas de responsabilização civil e penal sempre a posteriori.

Assim, a sistemática cunhada no exame do caso Ellwanger parece ter encontrado respaldo na jurisprudência recente do STF. Relativamente ao tema desta monografia, entende-se possível aproveitar as lições ditadas sobre os limites do direito de manifestação do pensamento para bem interpretar os limites do direito de petição.

Esse direito é, em princípio, ilimitado, no sentido de que não se pode impedir, previamente, que o particular formule pedidos perante os Poderes Públicos. Mais que isso: não se pode permitir que, de modo igualmente apriorístico, esses Poderes deixem de dar resposta aos pleitos formulados. Porém, se a formulação desses pedidos implicar abusos, de molde a gerar prejuízos a terceiros (tomando-se, em especial, os seus potenciais e efetivos concorrentes), não há óbice para que os eventuais peticionários venham a ser responsabilizados.

Aplica-se, também aqui, a "excludente de abusividade" consubstanciada na “convicção política". Em princípio, pedidos que externem concepções relacionadas ao modo de estruturação e funcionalização dos governos estão excluídas de gerar eventual responsabilização. Note-se, porém, que esse é o limite da "excludente de convicção política”. Eventuais pedidos que, sem defender qualquer concepção desse jaez, gerem prejuízos diretos a terceiros (concorrentes ou consumidores), podem configurar abuso e, sob a ótica do direito concorrencial, configurar ilícito antitruste. Para a configuração

\footnotetext{
${ }^{450}$ STF, ADPF 130/DF, rel. Min. Carlos Britto, j. 30.4 .2009 (Notícia: “ADPF e Lei de Imprensa - 8”, Informativo $\mathrm{n}^{\circ} 544$ ).

${ }^{451}$ STF, RE 511961/SP, rel. Min. Gilmar Mendes, 17.6.2009. (Notícia: “Art. 4º V, do Decreto-lei 972/69: Exigência de Curso de Jornalismo e Não-recepção - 6”. Informativo 551).
} 
concreta do abuso, podem ser utilizados os parâmetros do art. 187 do Código Civil, bem como as situações de sham exception desenvolvidas pela doutrina norte-americana.

\subsubsection{Desvio de Poder}

Outra teoria jurídica cunhada para lidar com ações que, prima facie, são lícitas é a relacionada ao desenvolvimento da noção de desvio de poder. Como trata da atuação de autoridades administrativas no exercício de competências a elas outorgadas, faz sentido examiná-la no bojo do presente trabalho (que, afinal, visa a examinar problema verificado no exercício da regulação e, por conseguinte, no desempenho de tarefa outorgada à Administração Pública).

A ideia de desvio de poder surge na jurisprudência do Conselho de Estado francês em meados do século XIX. ${ }^{452}$ Esses julgados fundamentam o desenvolvimento da noção ao longo do século XX, que pode ser sumariamente definida como a situação em que "o agente público pratica o ato visando a um fim - público ou privado, pouco importa - diverso daquele previsto na regra de competência para a qual o poder discricionário foi instituído (p. ex., transferência de funcionário, não por necessidade de serviço, mas por vingança pessoal; desapropriação de um bem porque o proprietário faz oposição ao governo; utilização do poder de política para fins fiscais)." ${ }^{453}$

A construção da teoria percorreu um longo caminho de contraposições. A primeira questão que surgiu era a de se saber se o desvio de poder caracteriza um vício moral ou um vício de legalidade. Mesmo considerado um vício de legalidade, a indagação seria quanto ao elemento do ato administrativo que estaria comprometido: a competência

452 Segundo CAIO TÁCITO, a noção de desvio de poder (ainda denominada como excesso de poder) é delineada, pela primeira vez, no caso Lesbats (1864/1865). A ele, seguem-se outros dois casos: Bouchardon (1870) e Ville de Cannes (1917), que firmam as bases de aplicação da idéia de desvio de poder (“O desvio de poder no controle dos atos administrativos, legislativos e jurisdicionais". Revista de Direito Administrativo. vol. 228, abr-jun 2002, p. 1-12). JOSÉ CRETELLA JR. faz referência a acórdão anterior ao caso Lesbats que tratou do tema (caso Vernes), mas reconhece que foi o caso Lesbats que fixou os parâmetros da noção de desvio de poder posteriormente utilizados na jurisprudência francesa ( $O$ desvio de poder na Administração Pública. $4^{\mathrm{a}}$ ed., Rio de Janeiro: Forense, 1997, p.120).

453 Almiro do Couto E Silva. "Poder discricionário no Direito Administrativo Brasileiro". Revista de Direito Administrativo. vol. 179-180, jan-jun 1990, p. 63. A teoria de desvio de poder é adotada na Alemanha, na Itália, na Espanha e em Portugal. Quanto à aplicação da teoria na Alemanha, ver VITOR NUNES LEAL ("Poder discricionário e ação arbitrária da Administração" Revista de Direito Administrativo. vol. XIV, Rio de Janeiro, out.-dez 1948, p. 53-82). Quanto à aplicação nos demais países, ver JOSÉ CRETELLA JÚNIOR ( $O$ desvio de poder na Administração Pública. Ob. cit., passim). No Brasil, a aplicação da teoria encontrava amparo legal desde o século XIX, na Lei $\mathrm{n}^{\circ} 221$ de 1894 (art. 13, 9, $b$ ), ainda que sob referência a "excesso de poder”. Na jurisprudência, CELSO ANTÔNIO BANDEIRA DE MELlo afirma que o leading case brasileiro acerca da aplicação dessa teoria é acórdão do Tribunal de Justiça do Rio Grande do Norte, de 1948, examinado com mais detalhes adiante (Curso de direito Administrativo. Ob. cit., p. 372, nota 34). 
do agente ou a finalidade do ato. Além dessas, outras questões se colocaram: desvio de poder só se caracteriza pela busca de interesse privado ao invés do interesse público ou, também, pela busca de interesse público diverso daquele subjacente à norma que outorga competência? Mais: o desvio de poder configura um vício subjetivo (que recai sobre o móvel de atuação do agente administrativo) ou um vício objetivo?

$\mathrm{Na}$ atualidade, algumas dessas indagações são respondidas com certa tranquilidade pela doutrina brasileira. É corrente a idéia de que o desvio de poder envolve um vício de legalidade ${ }^{454}$, que recai sobre o elemento "finalidade" do ato administrativo. 455 Também é usual a noção de que haverá desvio de poder em duas situações: tanto nas ocasiões em que o agente administrativo deixa de perseguir o interesse público para, em seu lugar, buscar o interesse privado; quanto nas situações em que busca interesse público diverso daquele subjacente à norma que lhe outorga competência para agir.

Quanto à natureza do vício (se subjetivo ou objetivo), permanece, ainda, alguma divergência de posicionamento. Há doutrina autorizada que o considera como um vício subjetivo, cuja configuração depende da consideração quanto às intenções subjetivas do agente administrativo, isto é, "é preciso indagar se os móveis que inspiram o autor de um ato administrativo são aqueles que, segundo a intenção do legislador, deveriam realmente inspirá-lo" ${ }^{456}$ Mais recentemente, essa idéia é afastada - mesmo por aqueles que anteriormente a sustentavam - para entender o desvio de poder como um vício objetivo, no qual "o que importa não é se o agente pretendeu ou não discrepar da finalidade legal, mas

\footnotetext{
${ }^{454}$ Nesse sentido, consulte-se o apanhado doutrinário constante da obra de JOSÉ CRETELLA JR. $O$ desvio de poder na Administração Pública. Ob. cit., p. 183-190.

${ }^{455}$ Embora, na atualidade, prevaleça a idéia de que o desvio de poder revela um vício de finalidade, não se ignora a relação estreita existente entre o vício de desvio de poder e a questão da competência administrativa. Isso pode ser apanhado na obra de MARIA SYLVIA ZANELlA DI PIETRO, segundo quem, enquanto desvio de poder é vício de finalidade, excesso de poder é vício de incompetência. E ambos são espécies do gênero "abuso de poder" (Direito Administrativo. $22^{\mathrm{a}}$ ed., São Paulo: Atlas, 2009, p. 239). Essa aproximação também se faz presente nos estudos de CELSO ANTÔNIO BANDEIRA DE MELlo, cuja exposição da teoria do desvio de poder funda-se na idéia de um mau uso da competência administrativa e no desacordo objetivo entre finalidade do ato e finalidade da competência (Curso de direito Administrativo. Ob. cit., p. 372-374). AFONSO RODRIGUES QUEIRÓ explica adequadamente as razões dessa conexão. Segundo o autor português, "A competência é um poder e um dever de realizar certas esferas ou círculos de atividades, de interesses públicos" ("A teoria do 'desvio de poder' em Direito Administrativo". Revista de Direito Administrativo. vol. VII, jan-mar 1947, p. 74). Esse "círculo objetivo de interesses" - que delineia a competência - pode ser compreendido como a finalidade do agir administrativo ("A teoria do 'desvio de poder' em Direito Administrativo". Ob. cit., p. 76).

${ }^{456}$ José CRETElla JR. Do ato administrativo. São Paulo: Bushatsky, 1977, p. 184. Adiante, o autor reitera que o desvio de poder é vício que "emana do motivo subjetivo" do agente responsável pela prática do ato (Do ato administrativo, Ob. cit., p. 209).
} 
se efetivamente dela discrepou". ${ }^{457}$

Nesse ponto, é esclarecedora a lição clássica de AFONSO RODRIGUES QUEIRÓ, que vislumbra a existência de dois tipos de desvio de poder: aquele em que há uma violação intencional da "regra de interesse público" pelo agente público (e, então, há um vício de moralidade administrativa) e aquele em que o agente público ultrapassa os limites objetivos de atuação (e, então, há um vício de legalidade consubstanciado na incompetência). ${ }^{458} \mathrm{Em}$ que pesem as referências à moralidade administrativa e à vício de competência, a distinção cunhada pelo autor português parece diferenciar duas realidades que, efetivamente, não se confundem: uma é a eventual contaminação do móvel subjetivo do agente público; outra é a sua atuação objetiva contrária aos limites ditados pela lei. A questão está em que, se a idéia de desvio de poder for mantida como coincidente com a primeira forma identificada por QUEIRÓ, a teoria que dela decorre torna-se inoperante. Sob certo aspecto, o AUTOR reconhece que, se o motivo e a motivação não evidenciarem o móvel subjetivo do agente, será impossível para a parte interessada evidenciar o vício e efetivar o seu controle. ${ }^{459}$ Assim, menos que uma contraposição entre as naturezas subjetiva e objetiva do vício (pois há, efetivamente, vício das duas índoles), a questão envolve reconhecer os limites em que se pode exercer o controle desse tipo de vício da atuação administrativa. Nesse sentido, o reconhecimento da vertente objetiva do defeito do ato administrativo permite não só a identificação mais clara e precisa do defeito do ato administrativo, mas também é aquela que se figura mais útil. Afinal, o controle preciso do móvel do agente administrativo é, na maioria das vezes, impossível. Ou ele se revela no processo administrativo prévio e nos elementos do ato administrativo editado; ou se manterá incólume. ${ }^{460}$

${ }^{457}$ Celso AntôNIo BandeIRA De Mello, Curso de Direito Administrativo, Ob. cit., p. 863. Segundo o próprio autor, até a quarta edição da obra ora citada, sustentava-se que a configuração do desvio de poder dependia da presença de uma intenção inadequada do agente (ver, a respeito, Curso de Direito Administrativo, Ob. cit., p. 373).

458 “"A teoria do 'desvio de poder' em Direito Administrativo". Ob. cit., p. 58 e p. 80.

459 "A teoria do 'desvio de poder' em Direito Administrativo". Ob. cit., p. 57. Mais adiante, AFONSO RODRIGUES QUEIRÓ chega a indicar que a demonstração de ocorrência de desvio de poder na vertente de vício do móvel do agente depende de prova "a demonstrar, positivamente, que o agente agiu por um motivo administrativamente imoral" ("A teoria do 'desvio de poder' em Direito Administrativo". Ob. cit., p. 78). Todavia, tal referência não invalida a constatação anterior. Só se pode cogitar de obtenção de prova positiva se há algum tipo de manifestação externa do agente administrativo que demonstre essa circunstância. Caso não haja, não há condições de se reconhecer o vício (ainda que, efetivamente, o móvel interno e subjetivo do agente esteja comprometido).

${ }^{460}$ Quem reconhece o desvio de poder como vício da intenção do agente administrativo, destaca que a sua ocorrência se comprova por indícios. Haveria, assim, alguns "sintomas" que podem evidenciá-lo, tais como “a) a motivação insuficiente; b) a motivação contraditória, c) a irracionalidade do procedimento, 
Exposta a teoria do desvio de poder, a questão que imediatamente se coloca é a de saber em que medida essa teoria - aparentemente consolidada e, quiçá, tradicional do Direito Administrativo - relaciona-se com o exercício da regulação e o problema da captura que se procura examinar no presente estudo.

Em primeiro lugar, deve-se destacar que a preocupação da teoria do desvio de poder e a da investigação quanto ao problema da captura são bastante similares. Entender que há desvio de poder quando o agente administrativo deixa de buscar o interesse público para tutelar interesse de outra índole (inclusive eventuais interesses privados) não é muito distante da afirmação de que o problema da captura ocorre quando o regulador tutela interesses específicos (privados ou políticos) em detrimento do interesse geral. Aliás, o “abuse of discretion” - que, segundo CAIO TÁCITO ${ }^{461}$, é a versão anglo-saxã do desvio de poder - é justamente um dos parâmetros para exame (e consequente controle) da atuação das agências norte-americanas (dentre as quais estão, por certo, as agências reguladoras independentes). ${ }^{462}$ Depois, não se deve olvidar que os leading-cases da teoria do desvio de poder (em França e no Brasil) envolvem o exercício (ou tentativa de se exercer) regulação econômica. ${ }^{463}$

acompanhada da edição do ato; d) a contradição do ato com as resultantes dos atos; e) a camuflagem dos fatos; f) a inadequação entre motivos e os efeitos; g) a motivação excessiva." (JosÉ CRETELLA JR., Do ato administrativo. Ob. cit., p. 209-210). Ocorre que se esses "sintomas" forem identificados, não será preciso recorrer ao desvio de poder para anular o ato. Ele já será nulo por vício de motivação ("a", "b", "f" e, eventualmente, "g"), por afronta ao due process of law no processo administrativo que lhe dá origem ("c" e "d") ou por vício de motivo ("e" e "f").

461 "O desvio de poder no controle dos atos administrativos, legislativos e jurisdicionais". Ob. cit., p. 1-12

${ }^{462}$ Segundo R. B. HORWITZ, o Administrative Procedure Act (APA) permite que o Judiciário verifique se a atuação da agência foi "arbitrary, capricious or an abuse of discretion" (The irony of regulatory reform. Ob. cit., p. 85).

${ }^{463}$ Em França, o caso paradigma - caso Lesbats - envolveu serviço de transporte de passageiros entre a estação rodoviária de Fontainebleau e o centro da cidade. À época, havia norma legal (L'ordonnance royale de 15 de novembro de 1846) que atribuía poder de polícia aos prefeitos - mediante posterior aprovação do Ministro de Obra Pública - para disciplinar o tráfego no pátio das estações ferroviárias. O Sr. Lesbats pediu autorização para estacionar ônibus de sua propriedade na estação ferroviária de Fontainebleau. O pedido foi deferido condicionalmente. Para que pudesse estacionar os ônibus (e, assim, prestar o serviço de transporte de passageiros), o Sr. Lesbats deveria: (i) disponibilizar ônibus suficientes para atender a todos os trens que parassem na referida estação (tal como fazia o Senhor Richard, pessoa subvencionada pela companhia ferroviária para prestar serviço similar); (ii) providenciar veículos especiais para o transporte de hóspedes de determinado hotel (L'hôtel de l'Europe). Esses veículos especiais vincular-se-iam exclusivamente ao transporte dos hóspedes, de modo que não poderiam ser utilizados para o cumprimento da primeira condição. O Sr. Lesbats contrapôs-se às condições impostas, consignando que a imposição de obrigações extrapolava os limites da competência do prefeito no caso concreto (que se limitava ao exercício do poder de polícia). Defendeu, também, que a imposição da obrigação de atender a todos os trens atentava contra a iniciativa privada, pois tornava impossível que outros particulares fizessem concorrência para o Sr. Richard (subvencionado da companhia ferroviária para a prestação desse serviço). Os argumentos foram acolhidos pelo Conselho de Estado, para quem, em vez de disciplinar o tráfego do local, as competências administrativas foram utilizadas com o objetivo de intervir nas condições de concorrência entre as empresas 
Essas constatações permitem afirmar que a teoria do desvio de poder é um instrumental teórico - já acolhido em direito positivo ${ }^{464}$ - que permite controlar desvios próximos àqueles verificados quando há a captura do regulador. Em um primeiro momento, poder-se-ia, até mesmo, afirmar que parcela do "risco da captura" já encontra "tratamento" no sistema jurídico por meio da teoria do desvio de poder. Todavia, não se pode olvidar que há dificuldades para aplicar a teoria à realidade contemporânea.

A teoria do desvio de poder parte de premissa objetiva: haverá desvio de poder - independente do móvel do agente - se houver discrepância entre o fim definido em lei e o fim perseguido pelo ato. A dificuldade para a aplicação da teoria está no

que prestam o serviço de transporte. E, na medida em que tais objetivos não se inseriam nas regras que atribuíam competência ao prefeito e ao Ministro de Obras públicas, era o caso de se anular as condições estabelecidas nas autorizações concedidas ao Sr. Lesbats (a versão integral do julgado foi consultada em LM. Devilleneuve, A.-A. CARette e P. Gilbert. Recueil Général des Lois et des Arrêts en matiére civile, criminelle, administrative et de droit public. Paris: Bureaux de L'Administration du Recueil, 1865, p. 218222).

No leading case brasileiro, a questão envolvia o serviço de transporte entre Natal e a cidade de São José de Mipibú. Certa empresa (Empresa de Transporte Potiguar Ltda.) pediu autorização administrativa para incluir um novo veículo na linha "Natal- São José de Mipibú". Esse novo ônibus sairia de São José de Mipibú às 07h00 em direção a Natal e regressaria às $17 \mathrm{~h} 00$. De acordo com o requerimento, esse novo veículo atenderia, de modo mais adequado, aos trabalhadores de São José de Mipibú que trabalhavam em Natal. Além disso, os horários propostos não coincidiam com os horários em que já havia transporte à disposição dos usuários (seja prestado pela Potiguar, seja prestado pela concorrente - a empresa "Serviço de Transporte Mipibuense"). O pedido foi dirigido à Inspetoria Estadual de Trânsito, que tinha competência para, ao lado de outras autoridades, supervisionar o serviço de transporte coletivo de passageiros. Ocorre que as razões do pedido não foram examinadas. Em vez de autorizar a inclusão do novo veículo no horário pleiteado, a Administração autorizou que o referido ônibus saísse às 10h00 de São José de Mipibú e regressasse às $22 \mathrm{~h} 00$. A Potiguar voltou-se contra esse ato administrativo por meio de mandado de segurança. $\mathrm{O}$ ato foi anulado pelo Tribunal de Justiça do Rio Grande do Norte, que constatou a ocorrência de desvio de poder. Primeiro, o acórdão considerou os horários fixados pelo ato administrativo. Naqueles horários, parecia não haver interesse na prestação do serviço. Aliás, quanto ao horário de $22 \mathrm{~h} 00$, verificar-se-ia que a Potiguar concorreria consigo mesma (a par do pouco movimento no horário, o ônibus anterior - que partia de Natal às 21 h00 - já era seu). Depois, de acordo com o julgado, o horário sugerido pela Potiguar era razoável. A inclusão de um novo ônibus às $17 \mathrm{~h} 00$ não só permitiria uma partilha equilibrada de usuários entre os prestadores de serviço (já que o único ônibus do final da tarde tinha a sua partida programada para 18h30min e era disponibilizado pela concorrente), como também viabilizava a melhor prestação do serviço (afinal, os usuários que terminassem a jornada de trabalho até às $17 \mathrm{~h} 00$ poderiam apanhar o novo veículo e o ônibus de 18h30min poderia prestar de modo mais adequado o serviço para os usuários remanescentes). Quando a Administração rejeitou o pedido da Potiguar, manteve toda a demanda centralizada na Mipibuense (sem justificativa apta a fundamentar tal posição). Em terceiro lugar, havia outros dados objetivos que indicavam o favorecimento da Mipibuense (por exemplo, somente ela tinha a possibilidade de realizar viagens extraordinárias - quantas quisesse e nas horas que bem entendesse). Por fim, a regulação exercida sobre a atividade também se revelava sui generis. Isso porque, dentre os serviços de transporte rodoviário submetidos à regulação da mesma Inspetoria, o único trecho rodoviário que contava com o estabelecimento de horários fixos para a saída dos ônibus era a linha "São José de Mipibú-Natal". A reunião dessas circunstâncias permitiu que o Tribunal identificasse desvio de poder no exercício da competência administrativa que, em vez de bem regular o serviço em questão, tinha em mira conceder privilégio a uma das empresas prestadoras de serviço (BRASIL. Tribunal do Rio Grande do Norte, Apelação Cível n 1422, Relator Desembargador SEABRA FAGUNDES, publicado na Revista de Direito Administrativo, vol. XIV, Rio de Janeiro, out-dez 1948, p. 52-82).

${ }^{464}$ Nos termos do art. $2^{\circ}$, par. único, $e$, da Lei 4.717/65 (Lei de Ação Popular), “o desvio de finalidade se verifica quando o agente pratica o ato visando a fim diverso daquele previsto, explícita ou implicitamente, na regra de competência". 
recolhimento das provas do desvio perpetrado pelo ato. Porém, uma vez obtidas tais provas, a atividade torna-se relativamente simples: há uma finalidade legal identificável de plano que diverge daquela buscada no ato. ${ }^{465}$ Todavia, se essa singeleza pode estar presente nos atos em que o Estado exerce as competências herdadas do Estado Liberal (isto é, quando pratica atos unilaterais como são os atos de punição, de expropriação e de arrecadação fiscal, por exemplo), ela se esvai com o advento do Estado Intervencionista. Com ele, é necessário se reconhecer que "O comum da actividade dos órgãos públicos está assim hoje a desenvolver-se fora daquele domínio que serviu de base à teoria clássica do direito administrativo." 466

Especificamente no que concerne ao controle da atividade administrativa, ROGÉRIO EHRARDT SOARES destaca que, se a Administração Tradicional era constituída "por um sistema mais ou menos ordenado de serviços, sujeitos a controlo hierárquicos apertados", os interesses sociais que passam a reclamar a atividade estatal e, mesmo, a se colocar em conflito "não se converteram apenas em motor da aparelhagem administrativa tradicional". Diversamente, esses interesses "Com frequência, organizam-se, institucionalizam-se em grupos e vão lançar-se ao assalto da Administração, procurando afirmar interesses sectoriais como interesses públicos gerais da comunidade, utilizando para isso processos que vão desde a pressão indirecta até à própria compressão e desafio. $\mathrm{O}$ que quer dizer que a Administração pública muitas vezes está a falar uma voz que não é a sua". 467

Ainda na esteira do ensinamento de RoGÉrio EHRARDT SOARES, se, em face da Administração Tradicional, a teoria de desvio de poder parecia ter resolvido o problema do controle da discricionariedade administrativa, o tema ressurge no Estado Intervencionista. Nas palavras do AUTOR,

Ora, acontece que o desenvolvimento da Administração constitutiva complicou de tal modo as condições da previsão legislativa, que as normas foram cada vez mais dando guarida a conceitos imprecisos, a cláusulas gerais, que deixam ao agente um especial encargo de preenchimento de seu conteúdo. E aquilo que parecia ser um capítulo pacificado da teoria do direito administrativo

\footnotetext{
${ }^{465}$ Fala-se em identificação "de plano" da finalidade legal do ato administrativo porque, tradicionalmente, afirma-se que um dos atributos do ato administrativo é a tipicidade, segundo a qual "o ato administrativo deve corresponder a figuras definidas previamente pela lei como aptar a produzir determinados resultados. Para cada finalidade que a Administração pretende alcançar existe um ato definido em lei." (MARIA SYLVIA ZANElla Di PIETRO. Direito Administrativo, Ob. cit., p. 201, original sem destaque).

466 ROGÉRIO EHRARDT SOARES, "Princípio da legalidade e Administração constitutiva". Boletim da Faculdade de Direito da Universidade de Coimbra. vol. LVII, Coimbra, 1981, p. 176.

467 "Princípio da legalidade e Administração constitutiva", Ob. cit., p. 177.
} 
voltou, desde a década de 50, a transformar-se num mar de encapeladas discussões. ${ }^{468}$

Portanto, e se a teoria do desvio de poder pode auxiliar no "tratamento" do risco da captura, há de se reconhecer os seus limites já no Estado Intervencionista. Primeiro, no bojo do Estado Intervencionista, a Administração "não fala sozinha". E, então, os problemas a serem enfrentados são mais complexos. Aqui, não há somente as situações em que o próprio administrador público pratica atos movidos por finalidade diversa da pública, mas especialmente as situações em que esse administrador está sujeito à influência (algumas vezes até mesmo inconsciente) de grupos de interesses. Depois, a tipicidade do ato administrativo - que permitia identificar com relativa tranquilidade a finalidade legal a ser atingida pelo ato - se esvai. Demandam-se da Administração tantas atuações e de naturezas tão diversas que, na maioria das vezes, o interesse público a ser buscado não é estabelecido pela lei (que se limita a determinar que o próprio administrador o dite) ${ }^{469}$ Assim, a situação sobre a qual incide a teoria torna-se mais difícil sob dois ângulos: por um lado, os problemas enfrentados são mais intensos; por outro, as finalidades que se buscam por meio da atuação da Administração não são tão precisas.

No que concerne ao Estado Regulador e à regulação setorial a ele subjacente, às dificuldades anteriormente salientadas, agregam-se outras, que não pode ser olvidadas.

Primeiro, a dinâmica da regulação é complexa. Há uma diferenciação interna entre os próprios agentes econômicos que compõem o grupo de regulados, de forma que uma mesma norma, aplicada de modo uniforme no setor, pode atingi-los de forma diferenciada. Um exemplo nítido desse dado são as regras de portabilidade criadas no setor de telefonia. Se essas regras podem ser benéficas para os agentes que ingressam no mercado, são prejudiciais para os operadores históricos e que contavam com o "custo de mudança" como uma mecanismo para manter a carteira de usuários. Justamente porque há essa diferença, pode haver a criação de regras diferentes para os agentes econômicos, a depender da posição que ocupem no setor que se visa a regular. O exemplo também vem do setor de telefonia e envolve a regulação do preço pelo uso de redes. Por vezes, é necessário editar regras diferentes para os operadores históricos (que detêm as redes) e para os ingressantes no mercado (que ocupam as redes). Além disso, pode haver um policentrismo regulatório, em que há uma multiplicidade de instâncias regulatórias a atuar

\footnotetext{
468 "Princípio da legalidade e Administração constitutiva", Ob. cit., p. 187.

${ }^{469}$ Quanto às dificuldades da noção de interesse público, ver item 2.2.2., acima.
} 
sob um mesmo setor. ${ }^{470}$ Com efeito, a "assimetria entre regulados", a "assimetria entre regras regulatórias" e a "concorrência entre reguladores" aqui narrada torna problemática a aplicação pura e simples da teoria do desvio de poder, cunhada para uma realidade estanque e com marcos divisórios de repartição de competências muito bem definidos.

Afinal, quando se pretende levar a efeito a regulação de um setor econômico sensível, não se pode desprezar que o regulador está a exercer atividade regulatória destinada à manutenção e disponibilização dos bens e serviços sob regulação. Essa atividade não se confunde com a prática isolada de atos de regulação, pois "A atividade não significa ato, mas uma série de atos coordenáveis entre si, em função de uma finalidade comum". ${ }^{471}$ Assim, é necessário se ter em conta que, quando o regulador pratica os atos de sua competência, eles se inserem nessa "série de atos" (que obedecem dada ordem e unidade) com vistas à realização de determinado objetivo. ${ }^{472}$

Isso é especialmente relevante para a aplicação da teoria do desvio de poder, talhada para o controle de atos administrativos singularmente considerados. Se, ao examinar atos isolados, basta o contraste entre a ação isolada do administrador e a finalidade legal, no controle dos atos praticados na atividade regulatória, é necessário compreendê-los como parte de um conjunto que integra uma atividade. Em outras palavras: para que se possa compreender a finalidade do ato regulatório, não basta que ele seja examinado isoladamente; é necessário tomá-lo como parte da atividade regulatória (e, por conseguinte, considerar a finalidade que se busca com a atividade).

Diante do exposto, parece claro que as dificuldades identificadas nos parágrafos anteriores impõem obstáculos para que estejam reunidas as condições que autorizam a aplicação da teoria do desvio de poder. Assim, e embora a teoria do desvio de poder possa ter aplicação em casos similares ao do problema da captura, o seu locus de aplicação é reduzido, sendo inafastável a necessidade de que novos mecanismos mais condizentes com a realidade do Estado Regulador sejam cunhados.

De toda a forma, menos que contribuição emprestada para a minimização do

\footnotetext{
${ }^{470}$ As características da regulação contemporânea foram extraídas de Sabino Cassese, "Dalle regole del gioco al gioco com le regole". Ob. cit., p. 268-273.

${ }^{471}$ TUllio AsCARELl, "O empresário (L'impreditore)" Trad. de Fábio Konder Comparato. Revista da Faculdade de Direito da Universidade de São Paulo, vol. 92, São Paulo 1997, p. 270 (original sem destaque).

${ }^{472}$ Quanto à finalidade da regulação, ver o Capítulo I, acima.
} 
problema da captura, a teoria do desvio de poder parece fornecer algumas balizas para que se possa compreender os limites do controle e do tratamento do risco de captura. É inafastável (tal como se pretendeu indicar no exame da natureza do vício de desvio de poder) que parcela da atuação do agente administrativo restará incontrolada. O móvel do responsável pela regulação, se não apresentar manifestações fáticas e objetivas, permanecerá inacessível a controle. Esse reconhecimento de limites permitido pela teoria do desvio de poder pode ser incorporado nas referências ao problema da captura: se a captura é um risco (portanto, contingente), não pode ser tomado diretamente para fundamentar anulação de atos administrativos. Mas, além disso, às invocações do problema da captura - ainda que feitas retoricamente - se aplicam os limites reconhecidos na teoria do desvio de poder: não são plausíveis afirmações "gratuitas" de que a atividade regulatória por meio de agências reguladoras é, ipso facto, capturada (sem qualquer respaldo fático ou empírico que autorize tal ordem de considerações).

Afinal, e como há muito afirmava AFONSO RODRIGUES QUEIRÓ,

\begin{abstract}
"Se, além de um especial interesse público, a autoridade realiza também um interesse particular, seu ou de outrem, não é já incompetente; nesse caso, realiza uma duplicidade de interêsses: realiza um interêsse particular acessório, decorrente da realização de um interêsse público. Em tôda atividade administrativa, como atividade pública, há isso de característico: existe em benefício da comunidade e, portanto, dos administrados. O interesse público vai partilhar-se entre os particulares, difunde-se sob a forma de vantagens singulares. ${ }^{473}$
\end{abstract}

Por óbvio, não se quer que essa "distribuição de vantagens" - inafastável ao exercício da atividade administrativa - ocorra a partir de comportamentos estratégicos do agente administrativo, que deliberadamente visa a beneficiar mais alguns grupos que outros. Porém, há de se reconhecer que "a lei não pode ter a mão na sua [dele, agente administrativo] consciência, no seu [dele, agente administrativo] pensamento (...)"474, para afastar, diretamente, esse móvel interno do agir. Pode, como é evidente, desincentivá-lo e controlá-lo em suas manifestações objetivas. Mas aí se encontram os seus limites, sob pena de se afrontar idéias basilares e caras ao Estado de Direito.

\title{
5.3. O ambiente institucional propício a minimizar o problema da captura
}

Tal como evidenciado no item anterior, as teorias desenvolvidas pela dogmática jurídica que se propõem a tratar de situações que se encontram na "zona de fronteira" entre legalidade e ilegalidade encontram limitações. Se, por um lado, a aplicação

\footnotetext{
473 “A teoria do 'desvio de poder' em Direito Administrativo". Ob. cit., p. 77.

${ }^{474}$ AFONSO RODRIGUES QUEIRÓ, “A teoria do 'desvio de poder' em Direito Administrativo”. Ob. cit., p. 77.
} 
dessas teorias pode auxiliar no controle de condutas que poderiam configurar a ocorrência da captura; por outro, é evidente que envolvem atuações a posteriori e que só incidentalmente apanham situações de ocorrência de captura. Assim, e tomando-se a captura como um risco a ser prevenido, parece possível cogitar de desenhos institucionais que tentem precaver e minimizar a ocorrência desse risco.

Conforme já se referenciou nesse trabalho, instituições - tomadas genericamente como conjunto de regras formais e informais que disciplinam a atuação dos indivíduos - são aptas a criar restrições comportamentais. ${ }^{475}$ Assim, o estabelecimento de algumas regras jurídicas (devidamente acompanhadas de enforcement que garantam a sua aplicabilidade) podem funcionar como mecanismos de prevenção para o risco da captura.

De todo o modo, e antes de expor esses mecanismos, duas ressalvas precisam ser feitas.

Primeiro, e como já se insistiu em diversas passagens, uma das características do risco é o de serem eles contingentes. Assim, e ainda que racionalmente se cogitem de instrumentos de prevenção, pode ser que eles não sejam capazes de atingir os resultados que deles se esperam. Mais que isso: é possível que outros resultados, impossíveis de serem previstos no presente, acabem por ocorrer. ${ }^{476}$

Depois, instituições não envolvem apenas normas legais. Além delas, os diferentes contextos culturais (padrões de comportamento, costumes, tradições etc.) funcionam como instituições informais que, a par de também disciplinarem o padrão de comportamento dos indivíduos, influenciam o modo pelo qual as instituições formais são recepcionadas. Por isso, normas similares adotadas em sociedades diferentes tendem a gerar resultados diferentes. Como bem consigna Douglass NORTH, "Although the rules are the same, the enforcement mechanisms, the way enforcement occurs, the norms of behavior, and the subjective models of the actors are not. Hence, both the real incentive

\footnotetext{
${ }^{475}$ A respeito, ver item 2.1.2, $c$, acima.

${ }^{476} \mathrm{O}$ tema deste trabalho bem ilustra esse dado. Se é evidente que a decisão política de regular determinado setor por meio de agências reguladoras é uma medida com uma finalidade racionalmente justificável (manutenção da atividade regulada disponível à generalidade das pessoas), não se cogitava, a priori e antes da implementação da decisão, que dela poderia decorrer a facilitação da captura. Ou, para usar as palavras de OLIVER WILLIAMSON, "The creation and administration of a regulatory agency are both very intentional acts - although that is not to say that regulation does not have a (spontaneous) life of its own". (The mechanisms of governance. New York: Oxford University Press, 1996, p. 268)
} 
structures and the perceived consequences of policies will differ as well." ${ }^{\text {477 }}$ Diante do exposto, as chances de êxito de eventuais propostas parecem maiores quando: $(i)$ o contexto cultural em que as normas serão inseridas é considerado e (ii) preferem-se propostas de alterações graduais à adoção de modificações radicais. ${ }^{478}$ É, portanto, a partir dessas premissas que as sugestões para alteração do ambiente institucional em que se inserem as agências reguladoras independentes no Brasil são aqui formuladas.

\subsubsection{As situações propícias à ocorrência de captura}

Ao longo do segundo capítulo, procurou-se expor as diversas teorias que explicam as razões pelas quais o problema da captura pode ocorrer. Em linhas gerais, podem ser diagnosticadas quatro situações que "facilitariam" a ocorrência de captura das agências reguladoras independentes, quais sejam:

(i) a facilidade de organização de grupos de interesses com pequeno número de integrantes e com interesses coesos (tal como os regulados) em detrimento de grandes grupos de interessados na regulação (consumidores e usuários, por exemplo);

(ii) o aparecimento de um espaço de frouxidão (slack), em que o exercício de competências discricionárias não se submete ao conhecimento do público;

(iii) a possibilidade de a agência reguladora independente ver ignorada a sua autoridade pela deliberada desconsideração das regras por si editadas; e

(iv) o nível de informação quantitativa e qualitativamente menor das agências reguladoras em relação ao dos grupos regulados.

Em outras palavras, os problemas que podem propiciar a ocorrência de captura são (i) desproporção na representação de interesses, (ii) ausência de transparência na atuação da agência, (iii) "desautorização" das decisões regulatórias e (iv) assimetria de informações. Para a superação dessas quatro dificuldades, parece necessário implementar medidas que atinjam três finalidades: (i) ampliação da participação - especialmente

\footnotetext{
${ }^{477}$ Institutions, institutional change and economic performance. Ob. cit., p. 101.

${ }^{478}$ RICARDO ABRAMOVAY chama a atenção para esse segundo aspecto. Segundo o professor, "Não há receita nem muito menos leis científicas gerais que permitam antever o processo de superação de instituições ineficientes. O importante na contribuição de North é o caráter necessariamente gradual desta superação". ("Desenvolvimento e instituições: a importância da explicação histórica", 2001. Disponível em: <http://www.econ.fea.usp.br/abramovay/artigos_cientificos.htm>. Último acesso em: 20.06.2009.
} 
popular - no desenvolvimento da atividade regulatória, o que poderia reduzir a desproporção na representação de interesses e a assimetria de informações; (ii) reforço da autoridade da agência reguladora independente, a fim de reduzir a possibilidade de que as decisões por elas emanadas sejam "desautorizadas"; e (iii) ampliação da transparência da atividade regulatória. Tendo em vista esses fins, propõe-se a adoção de quatro providências (nenhuma delas propriamente inédita e algumas já consagradas no ordenamento jurídico pátrio), examinadas em detalhes nos itens a seguir.

\subsubsection{As medidas sugeridas para o tratamento do risco de captura}

\section{a) A lei de fixação de competências regulatórias}

As duas primeiras propostas envolvem o delineamento das leis de criação das agências reguladoras independentes e consequente outorga de discricionariedade para a atuação dessas agências. Sugere-se que essas leis $(i)$ definam os objetivos regulatórios a ser perseguidos pela agência reguladora; e (ii) outorguem competências por meio de critérios de validação de cunho finalístico.

A definição de objetivos regulatórios (ou, para usar a expressão normalmente empregada, a fixação de standards) é imposição do princípio da legalidade a que está sujeita a Administração Pública. Esse princípio não se satisfaz com delegação legislativa pura e simples, mas exige que a lei-quadro fixe os standards e os objetivos que precisam ser observados e perseguidos pela agência reguladora independente.

Essa fixação de objetivos viabiliza a segunda das propostas aqui defendidas no sentido de que a outorga de competências se dê por meio de regras com critério de validação finalística. Tal como já exposto, a validação finalística implica a necessidade de que a norma de nível inferior atinja as finalidades e os objetivos fixados pela norma de hierarquia superior. ${ }^{479}$ Portanto, o estabelecimento de objetivos regulatórios somado ao critério de validação finalística faz com que a outorga de discricionariedade não seja inconsequente. Ao contrário, ela implicará o comprometimento do regulador com as finalidades legais, por meio de critérios objetivamente colocados e que permitem o

\footnotetext{
${ }^{479}$ Sobre a diferença entre validação condicional e validação finalística, ver item 2.2.2., a, acima.
} 
controle da atividade desempenhada pelos reguladores. ${ }^{480}$ Nesse sentido, Gustavo BINEMBOJM destaca que

A dignidade da lei deve ser preservada como condição de existência de parâmetros de controle externos à atividade regulatória, que permitam aos cidadãos e agentes econômicos o acionamento de salvaguardas contra eventuais abusos. De outro lado, tais parâmetros ou standards funcionam como verdadeiras diretrizes democráticas a guiar o trabalho das agências, preordenando finalisticamente a sua atuação. ${ }^{481}$

Porém, e sem desconsiderar que a simples possibilidade de controle já tem papel relevante no delineamento das condutas dos indivíduos, ela parece ser o último dos benefícios que deriva da conjugação das duas medidas aqui apresentadas. Antes dele, a definição de objetivos somada à validação finalística contribui para ampliar a transparência da atividade regulatória. Sabe-se, de antemão (e mesmo antes de agência reguladora independente praticar qualquer ato), quais são as finalidades que devem ser privilegiadas por sua atuação.

Além disso, o estabelecimento de parâmetros para que se possa contrastar a atividade da agência reguladora independente permite que a sua autoridade seja reforçada cotidianamente. Entende-se que esse reforço ocorre em dois níveis. Primeiro, com a fixação de parâmetros objetivos, consegue-se visualizar com maior precisão a adequação da atuação da agência reguladora com a previsão legal. À autoridade da agência reguladora soma-se a autoridade da lei, como que em um reforço para imunizar a primeira contra eventuais desautorizações. Em segundo lugar, à medida que a atuação regulatória é submetida a controles precisos e os atos praticados pelas agências são mantidos, reforça-se a autoridade e a credibilidade dos atos praticados pela agência reguladora em um círculo virtuoso de reforço de autoridade e redução de eventuais desautorizações.

\footnotetext{
${ }^{480}$ Por certo, é como alerta CASS SUNSTEIN, a sugestão não resolve o problema por completo, pois "Estudos mostraram que edição de leis mais detalhistas pode produzir regulação capturada por acertos de facções" (“O constitucionalismo após o New Deal". Trad. de Jean Paul Cabral Veiga da Rocha. In: MATTOS, Paulo Todescan L. (Org.). Regulação econômica e democracia: o debate norte-americano. São Paulo: Editora 34, 2004, p. 175). Todavia, e mesmo assim, essa forma de normatização da atividade das agências ainda se revela mais adequada se comparada com a opção de disciplinar essa atuação por meio de normas de validação condicional. Nesse sentido, CASS SUNSTEIN indica que "Em particular, leis que especificam fins a serem atingidos são geralmente preferíveis àquelas que estipulam métodos particulares de regulação ou simplesmente identificam valores a ser sopesados. A legislação que especifica fins vinculantes (endsforcing), ao contrário das leis que especificam meios, garante flexibilidade e a aplicação de conhecimento técnico especializado. Leis que identificam meios, ao contrário, aumentam o risco de faccionismo; haja vista que métodos de promoção de finalidades não são freqüentemente parte visível do processo legislativo, grupos bem organizados podem ter um poder desproporcional na escolha desses objetivos". ("O constitucionalismo após o New Deal". Ob. cit., p. 176-177)

481 "As Agências Reguladoras Independentes e Democracia no Brasil”. Revista Eletrônica de Direito Administrativo Econômico. vol. 3, ago-out 2005, p. 12.
} 


\section{b) $O$ procedimentalização da atividade regulatória}

A sugestão para que as leis de instituição das agências reguladoras independentes definam os objetivos que devem ser perseguidos pelas agências por meio de normas finalísticas não resolve todos os problemas antes identificados. Admitindo-se que os fins sejam dados, os meios de que dispõem as agências reguladoras para atingi-los são, fundamentalmente, dois: (i) a edição de normas regulatórias (atos administrativos normativos); (ii) a prática de atos administrativos individuais, que envolve tanto os atos administrativos propriamente ditos, quanto eventual solução de controvérsia entre partes antagônicas.

Tanto a edição de normas, quanto a prática de atos administrativos propriamente ditos não devem ocorrer a esmo. Devem estar inseridas em um procedimento administrativo, em que estejam minimamente registradas as circunstâncias que geraram a prática do ato.

Essa procedimentalização contribui para a legitimação das decisões. ${ }^{482}$ Entende-se que isso ocorre não porque ela promoveria o consenso entre participantes com interesses divergentes (esse consenso, no mais das vezes, não ocorrerá), mas especialmente porque o processo funciona como instrumento para absorver as diferenças e prevenir as desilusões daqueles que não veem os seus posicionamentos tutelados. Nesse sentido, as palavras de TÉRCIO SAMPAIO FERRAZ JR., na apresentação da obra Legitimação pelo Procedimento, de NiKLAS LUHMANN:

Note-se, porém, que a função legitimadora do procedimento não está em se produzir consenso entre as partes, mas em tornar inevitáveis e prováveis decepções em decepções difusas: apesar de descontentes, as partes aceitam a decisão. (...) Neste sentido, a função legitimadora do procedimento não está em substituir uma decepção por um reconhecimento, mas em imunizar a decisão final contra decepções inevitáveis. ${ }^{483}$

Assim, a legitimação ocorre, justamente, quando se contorna a incerteza de qual será a decisão pela certeza de que haverá uma decisão. ${ }^{484}$ Relativamente aos processos

\footnotetext{
${ }^{482}$ Nesse sentido, Egon Bockmann Moreira, Processo Administrativo. $3^{\text {a }}$ ed., São Paulo: Malheiros, 207, p. 77 e ss e SÉRgIO VARELla BRUNA, Agências reguladoras: poder normativo, consulta pública e revisão judicial. São Paulo: Revista dos Tribunais, 2003, p. 181 e ss.

${ }^{483}$ NikLas LuHManN, Legitimação pelo procedimento. Trad. de Maria da Conceição Côrte-Real, Brasília: Editora Universidade de Brasília, 1980, p. 4.

$484 \mathrm{O}$ argumento é de TÉRCIO SAMPAIO FERRAZ JR., na apresentação à obra de NiKLAS LUHMANN (Legitimação pelo procedimento, Ob. cit., p. 5). Sobre a legitimação pelo procedimento na atuação das agências reguladoras independentes (utilizando, especialmente, os referenciais teóricos de NIKLAS
} 
da Administração Pública, LuHMANN destaca que "geralmente deve bastar para o caso da frustração pôr à disposição um processo semelhante ao processo judicial (...)". ${ }^{485}$ Essa semelhança implica dois dados fundamentais: (i) permitir a participação dos interessados nos processos administrativos e (ii) fundamentar as decisões administrativas. ${ }^{486}$

$\mathrm{Na}$ sequiência, pretende-se examinar esses dois dados, identificando o substrato legal do qual podem ser extraídos no ordenamento jurídico brasileiro e o modo como podem ser concretizados, bem como se espera detectar a forma como podem contribuir para a minimização do problema da captura.

\section{b.1) Participação nos processos de atuação das agências reguladoras}

Para que o processo administrativo possa ser tomado como tal, ao lado de sua instalação, é necessário garantir a participação dos interessados na decisão que, ao final, será proferida pela autoridade administrativa.

É corrente a admissão de tal participação relativamente a procedimentos que redundarão na prática de atos administrativos com reflexos diretos sobre a esfera jurídica dos indivíduos. Nesse sentido, milita não só a cláusula geral do devido processo legal (contemplada no artigo $5^{\circ}$, inciso LIV, da Constituição da República), mas especialmente as garantias ao contraditório e à ampla defesa contempladas no mesmo artigo $5^{\circ}$, inciso LV, da Constituição. Essa última disposição constitucional não deixa dúvida quanto à necessidade de que as pessoas sujeitas aos efeitos imediatos da decisão administrativa individual participem ativa e previamente do processo administrativo em que será proferida a decisão. ${ }^{487}$

LUHMANN), pode ser consultado o texto de SÉRGIO VARELla BRUNA (Agências reguladoras: poder normativo, consulta pública e revisão judicial. Ob. cit., p. 181 e ss).

${ }^{485}$ Legitimação pelo procedimento, Ob. cit., p. 170.

${ }^{486}$ Nas palavras de LUHMANN, haveria "disposições jurídico-administrativas às quais se pode (...) atribuir uma função legitimadora", quais sejam: (i) o "debate oral das leis [de processo administrativo]", (ii) o "direito de audiência" e (iii) a "lei de fundamentação de decisões administrativas" (Legitimação pelo procedimento, Ob. cit., p. 171). Fez-se alusão somente à participação e à fundamentação por se entender que participação se prestaria a reunir as duas primeiras figuras mencionadas por LUHMANN. De toda a forma, não se deve olvidar que LuHMANN põe em dúvida a capacidade de a Administração Pública assumir tarefas de legitimação que, inicial e precipuamente, cabem ao Legislativo (Legitimação pelo procedimento, Ob. cit., p. 171 e ss).

${ }^{487}$ É digno de nota o julgamento do Mandado de Segurança $\mathrm{n}^{\circ}$ 24.268, julgado pelo Pleno do Supremo Tribunal Federal (Supremo Tribunal Federal, Pleno, MS 24.268, Relator Ministro GILMAR MENDES, DJ 17.09.2004) 
Se isso parece claro relativamente a atos administrativos individuais, não é perceptível com tanta facilidade relativamente a atos administrativos normativos. $\mathrm{Na}$ medida em que a característica de atos administrativos normativos é, justamente, a abstração e generalidade, podem ser menos perceptíveis os efeitos que podem derivar de tais atos para os indivíduos. Porém, o fato de essa percepção não ser tão nítida não significa que ela esteja ausente.

Como é notório, a edição de normas jurídicas implica a alteração do padrão de conduta exigível das pessoas em geral ou de determinado grupo de pessoas que se submeta à hipótese de incidência da norma. A edição de novas normas pode, portanto, impor novos comportamentos aos indivíduos, muitas vezes por meio da criação de obrigações e proibições. Pode, portanto, promover alterações na situação jurídica das pessoas (ainda que prospectivamente). Se é assim, argumentos como o “[d]a imprescindibilidade de processo administrativo regular anterior à prática de atos da administração que venha a interferir na esfera de direitos e interesses particulares dos indivíduos"488 são extraíveis da cláusula geral do devido processo legal e parecem aplicáveis, também, à edição de normas regulatórias. Afinal, as normas jurídicas em geral (e as normas regulatórias em especial) prestam-se, justamente, a interferir na esfera de interesses - inclusive particulares - dos indivíduos.

Por certo, essa aplicação deve ter como medida a interferência que se promove sobre a esfera jurídica individual. É nítido que um ato administrativo punitivo interfere, com maior profundidade, sobre a esfera jurídica de certo indivíduo que a eventual edição de um ato administrativo normativo. E, consequentemente, as garantias do devido processo legal devem ser muito mais intensas na primeira situação (inclusive com a estrita observância às garantias da ampla defesa e do contraditório). Porém, essa constatação não autoriza concluir que, na segunda situação, a atividade administrativa pode se desenvolver sem qualquer vinculação à cláusula do devido processo legal. Diversamente, justamente porque é inafastável a constatação de que as normas regulatórias geram efeitos sobre a esfera jurídica de seus destinatários é que elas, como regra, devem ser editadas a partir de um processo administrativo em que se garanta participação daqueles que serão afetados pela norma a ser editada (direta ou indiretamente).

\footnotetext{
488 Superior Tribunal de Justiça. Recurso em Mandado de Segurança 18223/TO, 1ª Turma, Relator Ministro TEORI AlBino ZAVASCKI, DJ 25.09.2006.
} 
A questão que imediatamente se impõe é a de saber como se viabiliza essa participação.

Quanto aos processos relativos a atos administrativos individuais, essa participação normalmente se dará por meio de atividade de "parte processual" isto é, por meio da apresentação de pedido inicial ou de defesa (inclusive técnica), bem como pela produção de provas em contraditório e apresentação de manifestação antes da prolação da decisão. Nesse sentido, a Lei de Processo Administrativo Federal (Lei n. ${ }^{\circ}$ 9.784/99) é precisa. Permite que interessados formulem pedidos perante a Administração (artigo $5^{\circ}$ e $6^{\circ}$ ), ao mesmo tempo em que garante o acesso ao processo, a formulação de alegações e a produção de provas, que deverão ser consideradas pela decisão administrativa (artigo $2^{\circ}$, $\mathrm{X}$; artigo $3^{\circ}$, I, II, III, e VI).

Quanto aos processos administrativos relacionados a atos normativos, os instrumentos de participação não são tão bem definidos. Usualmente, tem-se que essa participação ocorrerá por meio de audiências e consultas públicas. ${ }^{489} \mathrm{Na}$ legislação das agências reguladoras independentes, encontram-se três tipos de disposições relativas ao assunto. A primeira espécie envolve tomar a realização de audiências e consultas como exigência específica que deve ser observada na edição das normas regulatórias. A segunda espécie refere-se a disposições gerais, que obrigam a realização de audiências ou consultas em situações definidas pela própria agência (mas não se estabelecem critérios ou requisitos mínimos para identificar as situações em que tais consultas e audiências devem ser realizadas e as consequências decorrentes da não-realização). A terceira espécie relacionase a situações em que a legislação faculta a realização de audiências públicas. Note-se que a ampla maioria dos diplomas legais encaixa-se na segunda e na terceira espécies, de molde que não se consegue visualizar, com precisão, qual seria o efeito de eventual não realização das audiências ou consultas. ${ }^{490-491}$ Talvez por isso, "parece que o

\footnotetext{
${ }^{489}$ Conforme o levantamento de LEILA CuÉLlAR, excetuando a Agência Nacional de Cinema - ANCINE, todas as demais agências reguladoras independentes da órbita federal prevêem a realização de audiência pública $\mathrm{e}(\mathrm{ou})$ de consulta pública (Introdução às agências reguladoras brasileiras. Belo Horizonte: Fórum, 2008, p. 155-163). Além das previsões específicas, a Lei de Processo Administrativo Federal admite a realização de consulta pública ("quando a matéria do processo envolver assunto de interesse geral") e de audiência pública ("diante da relevância da questão"), bem como o estabelecimento de outros meios de participação (em casos de "matéria relevante").

${ }^{490}$ Rigorosamente, somente a disposição da Lei de instituição da ANATEL se encaixaria na primeira espécie ao submeter a edição de atos normativos a procedimento prévio de consulta pública e ao exigir que a decisão que adotar seja acompanhada por exposição formal de motivos (artigos 40 e 42 da Lei n. ${ }^{\circ}$ 9.472/97). Na segunda espécie - em que as disposições seriam mais gerais - estariam incluídas as disposições das leis de instituição da Agência Nacional de Energia Elétrica - ANEEL (art. $4^{\circ}, \S^{\circ}$, da Lei n. ${ }^{\circ} 9.427 / 96$ ), Agência
} 
estabelecimento do requisito de audiência pública ou de participação popular nos procedimentos normativos vem sendo encarado como ato de mera liberalidade do Poder Público". 492

A despeito de a prática ter revelado esse tipo de tratamento, defende-se que o dever de realização de audiências e consultas públicas precisa ser levado a sério. Entende-se que, em princípio e como regra, os procedimentos de participação devem ser utilizados. A exceção seria a não-realização, que precisa estar devidamente justificada. Entende-se, ainda, que esse dever se estende mesmo às agências reguladoras para as quais os diplomas normativos se limitam a estabelecer a faculdade de realização de consulta e audiência públicas. Isso porque o desempenho de atividades normativas e a realização prévia de audiências e consultas públicas envolvem o exercício de competências administrativas que, como tal, são funcionalizadas. ${ }^{493}$ Assim, também essas têm o ônus argumentativo de justificar as razões pelas quais deixam de realizar audiência e consulta pública em dada circunstância.

Não se olvida que haverá situações em que essas audiências e consultas públicas não poderão ser realizadas ou não poderão ser realizadas de forma satisfatória. É evidente que, além dos eventuais custos, a realização desses procedimentos pode implicar a prolongação do processo de elaboração normativa, em contrariedade à agilidade e à eficiência que se pretende com a outorga de tais competências às agências reguladoras. Porém, essas situações devem ser tomadas como excepcionais e devem ser plenamente justificadas pela agência reguladora independente.

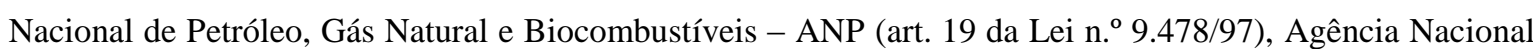
de Transportes Terrestres - ANTT (art. 68 da Lei n. ${ }^{\circ}$ 10.233/01), Agência nacional de Transportes Aquaviários - ANTAQ (art. 68 da Lei n. ${ }^{\circ}$ 10.233/01) e Agência Nacional de Aviação Civil - ANAC (art. 28 da Lei n. ${ }^{\circ}$ 11.182/2005). Por fim, na terceira situação, encontram-se duas realidades: aquela em que a faculdade de realização de audiência está contemplada em lei (como é o caso da Comissão de Valores Mobiliários - CVM, cuja previsão de consulta consta do art. $8^{\circ}, \S 3^{\circ}$, I, da Lei n. ${ }^{\circ} 6.385 / 76$ ) e as outras em que a previsão consta de atos infralegais (tal como nos artigos 32 e 35 do Decreto n. ${ }^{\circ} 3.029 / 99$, que regula a lei de criação da Agência Nacional de Vigilância Sanitária - ANVISA; nos artigos 32 e 35 do Decreto n. ${ }^{\circ}$ 3.327/00, que regula a lei de criação da Agência Nacional de Saúde Suplementar - ANS e no art. 72 do Regimento Interno da Agência Nacional de Águas - ANA - Resolução n. ${ }^{\circ}$ 348, de 20.08.2007).

${ }^{491}$ A classificação aqui empreendida inspirou-se na referência à diversidade de tratamento dos institutos da consulta e da audiência pública constante da obra de SÉRGIO VARELLA BRUNA, Agências reguladoras: poder normativo, consulta pública, revisão judicial. Ob. cit., p. 270 e ss). De toda a forma, as referências que constam da referida obra não têm o cunho classificatório que aqui foi levado a efeito.

${ }^{492}$ SÉRGIO VARELla BRUNA, Agências reguladoras: poder normativo, consulta pública, revisão judicial. Ob. cit., p. 251.

${ }^{493}$ Como salienta CElso ANTÔNIO BANDEIRA DE MEllo, ao outorgar competência à Administração, "O que a ordem jurídica pretende, então, não é que um dado sujeito desfrute de um poder, mas que possa realizar uma certa finalidade, proposta a ele como encargo do qual tem de se desincumbir." (Curso de Direito Administrativo, Ob. cit., p. 133). 
NiKLAS LUHMANN, ao examinar a realização dos debates orais previstos nas leis de processos administrativos, destaca que:

(...) a prática hesita, não sem uma razão compreensível, em conceder incondicionalmente um tal direito. A administração nunca pode, aliás, obter informações 'completas'; ela tem sempre que decidir sob a condição duma incerteza parcial, não pela não-existência de informações suficientes, mas sim porque os esforços para o seu emprego ou quanto ao esclarecimento da questão da sua existência, seriam demasiado dispendiosos. A medida em que é racional obter informações será logo objeto de cálculo próprio, em que entrariam não só os critérios de relevância dos programas, como também as questões de gastos de tempo, mão-de-obra, dinheiro, etc. Os limites do uso razoável de informações só poderiam ser averiguados através do cálculo administrativo interno." 494

Se em princípio seria possível afastar a realização de audiências e consultas públicas com base em tal cálculo de custo vs. benefício, fato é - prossegue LUHMANN - que “Atualmente isto é pura teoria, pois não existem modelos de decisão para situações administrativas práticas, modelos segundo os quais se pudesse calcular o uso de informações de acordo com custo e rendimento". ${ }^{495}$ Assim, "Enquanto a administração não puder justificar claramente a racionalidade duma renúncia a informações subsequientes, pode ser conveniente contrapor-lhe um direito de audiência (...)". 496

Portanto, em princípio, as audiências e consultas públicas devem ser realizadas. Deve-se "compreender que aqui, como em outros âmbitos do governo, o processo é o produto" ${ }^{\text {497 }}$, especialmente quando se torna plausível admitir que algumas medidas regulatórias acabam por transbordar os limites da técnica e envolver, também, algum caráter político. ${ }^{498}$

\footnotetext{
${ }^{494}$ Legitimação pelo procedimento. Ob. cit., p. 171-172.

${ }^{495}$ Legitimação pelo procedimento. Ob. cit., p. 172.

${ }^{496}$ Legitimação pelo procedimento, Ob. cit., p. 172.

${ }^{497}$ A frase é de JERRY MASHAW em crítica a reformas gerencialistas que propugnam por foco no "cliente", em "organizações simples" e no "corte de procedimentos burocráticos excessivos" ("Reinventando o governo e reforma regulatória: estudos sobre a desconsideração e o abuso do Direito Administrativo". Trad. de Caio Mário da Silva Pereira Neto. In: MATTOS, Paulo Todescan L. (Org.). Regulação econômica e democracia: o debate norte-americano. São Paulo Editora 34, 2004, p. 287). Como salienta o Autor, "É difícil, ou mesmo impossível, opor-se aos objetivos gerais da NPR 1 [Primeira Revisão de Desempenho Nacional]. Melhor serviço governamental a um custo menor não é algo controverso. O problema é que essas idéias ambiciosas referentes ao corte de procedimentos burocráticos excessivos [red tape regulation], ao foco primário em clientes, atribuição de poder aos funcionários e retorno a aspectos básicos parecem ignorar as atividades da maior parte das agências públicas federais" ("Reinventando o governo e reforma regulatória: estudos sobre a desconsideração e o abuso do Direito Administrativo” Ob. cit., p. 284-285).

498 A respeito, ver SÉRGIO VARELLA BRUNA, Agências reguladoras: poder normativo, consulta pública, revisão judicial. Ob. cit., p. 251. De toda a forma, deve-se esclarecer que quando se fala em "caráter político" não se quer fazer referência à política em sentido amplo (como correspondência a pressões do eleitorado). Diversamente, está-se a fazer referência àquelas situações em que há necessidade de levar a efeito juízos de valor em conformidade com a lei (CASS SUNSTEIN, "O constitucionalismo após o New Deal". Ob. cit., p. 170).
} 
Assim, e ainda que se admita que o exame da relação custo vs. benefício seja um argumento plausível para justificar a eventual não-realização da audiência ou consulta pública $^{499}$, deve-se salientar que os custos invocados para justificar a não-realização da audiência não podem se limitar aos dispêndios inerentes à realização do próprio procedimento, mas precisam considerar e apontar, com precisão, os prejuízos que podem ocorrer para a própria regulação do setor (e, em especial, para a manutenção da atividade), caso o tema não seja objeto de normatização imediata (e, que, portanto, inviabilizaria a realização da audiência ou consulta públicas). ${ }^{500}$ Por outro lado, entende-se que a produção de artificial "urgência" da regulação, isto é, a deliberada postergação na adoção das medidas necessárias para instalar o processo de edição normativa a ponto de chegar a momento em que não há mais tempo hábil para a realização da audiência ou consulta públicas pode, no limite, levar à edição do ato regulatório que se faça necessário sem a observância dessas medidas. Porém, essa circunstância deve gerar a responsabilização do agente responsável pela adoção das medidas que se faziam necessárias, inclusive com a aplicação das sanções cabíveis.

\footnotetext{
${ }^{499}$ Sob certo aspecto, à prevenção da captura em geral e à realização de audiência e consultas públicas como instrumentos particulares dessa prevenção pode ser aplicada a ideia de SUSAN ROSE-ACKERMAN acerca das medidas de combate à corrupção. Para a AUTORA,"The optimal amount of corruption is note zero even if one gives no value to the benefits received by bribers. Once one takes the costs of prevention into account, the level of deterrence expenditures should be set where the marginal benefits equal the marginal costs." (Corruption and government: causes, consequences and reform. New York: Cambridge University Press, 1999, p. 52). Em outras palavras: na medida em que se tem por impossível impedir in totum a ocorrência de captura (especialmente diante da sua configuração como risco), é necessário o balanceamento racional das medidas preventivas que se pretende utilizar para a prevenção do problema.

${ }^{500}$ Em sentido parcialmente diverso ao aqui defendido, SÉRGIO VARELLA BRUNA consigna que "o direito de ser ouvido durante a fase de gestação das normas administrativas, embora favoreça o espírito democrático, não pertence a nossa tradição política e, se disseminado para todos os casos, poderia prejudicar a eficiência da atividade estatal, retardando decisões que devem ser tomadas com presteza, ou mesmo, inviabilizando, em termos práticos, qualquer procedimento normativo, caso se exigisse a oitiva individual de todos aqueles que potencialmente afetados pela decisão. Por tal motivo, quando não haja procedimentos normativos expressamente exigidos em lei, não cabe condicionar a validade do ato normativo à sua observância" (Agências reguladoras: poder normativo, consulta pública, revisão judicial. Ob. cit., p. 276). Entende-se, todavia, que o fato de a participação popular poder prejudicar a presteza e a viabilidade da regulação não pode ser tomado como "dado" e como "regra" da generalidade dos procedimentos normativos. Embora esse prejuízo possa ocorrer, ele precisa ser tomado como exceção e justificado pela agência reguladora nos casos em que é identificado. Por outro lado, e conforme acima demonstrado, a regra geral nos diplomas legais de instituição das agências reguladoras independentes é a previsão de que audiências e consultas públicas sejam realizadas, de modo que a exigência legal de que tais medidas sejam adotadas é a regra (e não a exceção). Por fim, se é verdade que a realização de audiências e consultas públicas pode reduzir a velocidade e a quantidade de mudanças, essa redução talvez seja o preço a se pagar para obter deliberação mais participativa e legítima. Esse último argumento é inspirado em trecho do texto de CASS SUNSTEIN, em que o autor faz referência a um sistema amplo de controle sobre a atividade das agências reguladoras e afirma que "os riscos de poucas alterações podem ser o preço em que se incorreria para diminuir o facciosismo e aumentar a deliberação no governo"(“O constitucionalismo após o New Deal”, Ob. cit., p. 185”).
} 
Depois, levar a sério a realização de consultas e audiências públicas não implica a mera realização formal desses procedimentos. Primeiro, o tema a ser tratado na audiência e na consulta pública deve estar acessível ao público em geral. Mesmo que os temas envolvam questões com significativas especificidades técnicas, cabe à agência "traduzir" essas informações em linguagem laica, a fim de que o público possa minimamente compreender a questão e avaliar em que proporção aquelas medidas normativas poderão afetar a sua esfera individual de direitos e interesses. ${ }^{501}$ Depois, não basta recolher sugestões e pleitos sem que a eles seja dirigida uma resposta. Portanto, e nos mesmos moldes do direito de petição, a realização de audiência e consulta pública envolve uma via de mão-dupla, em que a agência reguladora independente recebe as sugestões e pleitos, examina-os e apresenta sua análise quanto a essas manifestações. Nesse ponto, deve-se destacar que a legislação brasileira tende a ser rigorosa, identificando-se com o primeiro momento da doutrina da hard look review norte-americana. Essa doutrina - que visa a traçar os parâmetros adotados para a revisão judicial dos atos emanados pelas agências reguladoras - inicialmente exigia que todas as manifestações dirigidas às agências tivessem sido examinadas. Posteriormente, concebeu-se que essa manifestação individual não seria necessária, mas, em lugar dela, dever-se-ia dar atenção a alternativas regulatórias que se colocavam ao lado da norma editada e a assuntos-chave para a edição das normas regulamentares. ${ }^{502}$ No Brasil, nos termos da regra geral estabelecida no art. $31, \S 2^{\circ}$, da Lei de Processo Administrativo Federal (Lei n. ${ }^{\circ}$ 9.784/99), “O comparecimento à consulta pública não confere, por si, a condição de interessado no processo, mas confere o direito de obter da Administração resposta fundamentada, que poderá ser comum a todas as

\footnotetext{
${ }^{501}$ Nesse sentido, JÚLIA BLACK, adotando como ponto de partida a teoria habermasiana, indica que, em um discurso, "a linguagem dos participantes pode ser tão diferente a ponto de impedir o entendimento" ("Procedimentalizando a regulação: parte II". Trad. de Denise Vitale Mendes. In: MATTOS, Paulo Todescan L. (Org.). Regulação econômica e democracia: o debate europeu. São Paulo: Editora 34, 2006, p. 187). Essa situação exigiria "tradução", entendida como "um processo de mediação horizontal entre sistemas ou grupos diferentes. É um processo, porém, que, para reiterar, não envolve simplesmente uma questão de encontrar uma correspondência lingüística entre as palavras; trata-se de encontrar formas de explicar e refletir sobre as lógicas diferentes desses grupos, de modo que outros possam compreender" ("Procedimentalizando a regulação: parte II". Ob. cit., p. 189). As dificuldades para que essa tarefa seja exercida pelo regulador é apontada pela AUTORA. Porém, saber o que (ou quem) poderia ocupar esse lugar ("associações", "esfera pública organizada", "sociedade cívica", "público cívico") é uma questão em aberto, de forma que, ao lado desses, JÚLIA BLACK admite que agências reguladoras poderão acabar por exercer esse papel facilitador (“Procedimentalizando a regulação: parte II". Ob. cit., especialmente p. 192-194, p. 198 e p. 201).

502 Agências reguladoras: poder normativo, consulta pública, revisão judicial. Ob. cit., p. 221 e ss. A relevância dessa alteração de posicionamento é salientada por MARTIN SHAPIRO. Segundo o AUTOR, "When a court says to an agency, not 'Consider all significant issues raised by the parties', but 'Consider all significant issues', it has made exactly that shift from pluralism to postpluralism. It no longer says, 'Listen to everybody in order to 'satisfice' them'. It now says, 'Do a synoptic job. Think of everything' - 'everything' bounded at the edges by rational cost constraints that tell us not to look at the insignificant." (Who guards the guardian. Ob. cit., p. 52).
} 
alegações substancialmente iguais". Portanto, a lei confere aos participantes o direito subjetivo à obtenção de resposta fundamentada para as manifestações que apresentem. ${ }^{503}$

Por fim, a realização de audiências e consultas públicas não resolve por completo o problema da participação. Primeiro, a dificuldade da ação coletiva exposta em diversas passagens do presente texto torna-se evidente aqui. Diante da facilidade de organização de grupos formados por um número limitado de agentes (especialmente quando comparada com as dificuldades de organização de grupos compostos por grande número de pessoas) torna claro que a tendência é a de que essas audiências e consultas públicas contem com participação mais intensa dos regulados (e não do público em geral). ${ }^{504}$

Porém, no Brasil, o que chama atenção não é tanto a grande participação dos grupos regulados - essa é, até mesmo, "natural" em virtude dos problemas de organização -, mas a baixíssima (senão nula) participação popular. Conforme salienta PAULO MATTOS, "Nesse contexto, cabe observar que o grau de participação dos grupos representantes do segmento específico de telecomunicações certamente será sempre alto, tendo em vista que se trata de uma agência reguladora do setor de telecomunicações. Contudo, é muito significativo o fato de que há uma baixa participação de órgãos de tutela dos interesses do cidadão". 505

Entende-se que essa constatação pode ser explicada por aspectos próprios da realidade brasileira. Costumeiramente, a produção normativa no Brasil não tem origem na sociedade civil ou no exercício de constantes pressões populares. Ou seja, não tem origem em movimentos voluntários de mobilização, mas em decisões imperativas postas pelo

\footnotetext{
${ }^{503}$ De todo o modo, o fato de a legislação outorgar esse direito subjetivo aos participantes não permite concluir que o regulador se desincumbe de seus deveres pela simples apresentação de resposta às manifestações apresentadas. Ao lado de tal exame, é imprescindível que o regulador analise as alternativas regulatórias que se colocam ao lado da opção normativa eleita e justifique a sua escolha. Esse dado, ainda que não derive diretamente da norma aqui mencionada, encontra respaldo no dever de fundamentação das decisões regulatórias, a ser examinado abaixo.

${ }^{504} \mathrm{O}$ argumento é comprovado por dados empíricos. Conforme a pesquisa de PAULO TODESCAN L. MATTOS, 68,69\% das participações nas audiências e consultas públicas realizadas pela ANATEL tinham origem em manifestação do grupo de regulados (aqui incluídas as manifestações das empresas, como também aquelas promovidas por consultorias e escritórios de advocacia que as representam). ("Agências reguladoras e democracia: participação pública e desenvolvimento". In: SALOMÃO Filho, Calixto (Coord). Regulação e desenvolvimento. São Paulo: Malheiros, 2002, p. 211-228) Por sua vez, EGON BoCKMANN MOREIRA aponta que no âmbito da ANEEL a participação levada a efeito pelos integrantes do setor é de aproximadamente 86\% ("Agências Reguladoras Independentes, déficit democrático e "elaboração processual de normas". Revista de Direito Público da Economia. vol. 2, Belo Horizonte, abr-jun 2003, p. 248).

505 (“Agências reguladoras e democracia: participação pública e desenvolvimento". Ob. cit., p. 228.
} 
Estado. ${ }^{506}$ Essa característica parece determinante para que se possa compreender a baixa participação em audiências e consultas públicas. Ora, o sucesso dessas figuras depende da participação voluntária e espontânea do público em geral. Como culturalmente essa não é a forma cotidiana de participação com pública, a tendência é a de que, ao menos em curto e médio prazo, esses instrumentos não consigam minimamente mobilizar a participação popular.

O dado é relevante porque se no modelo norte-americano de agências reguladoras a participação popular pode ser razoavelmente obtida por meio de instrumentos que disponibilizam a participação espontânea nos processos decisórios, a mera transposição do modelo para o Brasil não é suficiente para, de fato, propiciar efetiva participação. Os contextos em que as organizações e as instituições estão inseridas são diferentes, gerando, inevitavelmente, resultados diferentes. ${ }^{507}$ Por isso, entende-se que, a despeito da relevância das audiências e consultas públicas, é necessário cogitar de outro mecanismo que amplie a possibilidade dessa participação.

Nesse sentido, sugere-se que as agências reguladoras independentes possam adotar condutas ativas, solicitando a contribuição de entidades representativas dos interesses atingidos pela regulação em um mecanismo similar ao amicus curiae. A proposta funda-se na idéia de que, se a participação não for obtida espontaneamente, a voluntariedade pode ser instigada, mediante convite dirigido a entidades com representatividade no tema em discussão (universidades, associação de consumidores, associação de usuários, associações de proteção ambiental etc.).

\footnotetext{
${ }^{506} \mathrm{O}$ contraste entre as origens da legislação protetiva do consumidor nos Estados Unidos e no Brasil ilustram bem esse dado. Nos Estados Unidos, desde o século XIX, existem as Ligas de Consumidores (a New York Consumers' League foi criada em 1891 e a National Consumers League foi criada em 1899). Em meados da década de 50, alguns episódios impulsionam o movimento em favor do reconhecimento a certos direitos em favor dos consumidores. O exemplo emblemático envolveu a comercialização do medicamento talidomida. Recomendado para controlar enjôos matinais em grávidas, o medicamento tinha como efeito coleteral a má-formação do feto. A constatação desse problema gerou a mobilização da sociedade civil e, um ano após a suspensão de venda de tal medicamento, o governo Kennedy aprovou a Consumer Bill of Rights (em 1962), composta por 4 (quatro) direitos básicos: $i$ ) direito à segurança; ii) direito à informação; iii) direito à escolha e iii) direito de ser ouvido (confira-se ALEXANDRE VOLPI, A história do consumo no Brasil. Rio de Janeiro: Elsevier, 2007, p. 96). No Brasil, o "movimento" de proteção do consumidor surge, inicialmente, com os Procons (órgãos estatais, portanto) e com o Conselho Nacional de Defesa do Consumidor (Decreto 91.469, de 24.07.1985). Posteriormente, o dever de defesa do consumidor foi incluído entre as garantias fundamentais da Constituição da República (art. $5^{\circ}$, XXXII) e o Código de Defesa do Consumidor (Lei $\mathrm{n}^{\circ}$ 8.078/90) foi aprovado. Portanto, enquanto o movimento norte-americano tem origem essencialmente na sociedade civil, o movimento brasileiro tem seu fundamento na atuação estatal. Não obstante a existências de algumas associações civis (IDEC, v.g.), a criação dos Procons, do Conselho Nacional de Defesa do Consumidor e o próprio Código de Defesa do Consumidor comprovam essa afirmação (ALEXANDRE VolPI, A história do consumo no Brasil. Ob. cit., p. 101 e ss).

${ }^{507}$ A respeito, ver item 2.1.2., $c$; e item 5.4., acima.
} 
Note-se, aliás, que essa solução foi acolhida pelo ordenamento jurídico pátrio para feitos judiciais que envolvam temas de complexidade técnica ${ }^{508}$, mas também nos processos de controle de constitucionalidade abstrato (e, portanto, de cariz objetivo), nos quais o Poder Judiciário atua como "legislador negativo". A previsão contemplada no artigo $7^{\circ}, \S 2^{\circ}$, da Lei n. ${ }^{\circ}$ 9868/99 tem sido prestigiada pelo Supremo Tribunal Federal ao alertar que:

Não se pode perder de perspectiva que a regra inscrita no art. $7^{\circ}, \S 2^{\circ}$, da Lei ${ }^{\circ} 9.868 / 99$ - que contém a base normativa legitimadora da intervenção processual do "amicus curiae" - tem por objetivo essencial pluralizar o debate constitucional, permitindo que o Supremo Tribunal Federal venha a dispor de todos os elementos informativos possíveis e necessários à resolução da controvérsia, visando-se, ainda, com tal abertura procedimental, superar a grave questão pertinente à legitimidade democrática das decisões emanadas desta Corte (...), quando no desempenho de seu extraordinário poder de efetuar, em abstrato, o controle concentrado de constitucionalidade. ${ }^{509}$

Dessa forma, se a admissão da figura tem fundamento tanto na obtenção de informações úteis ao exame da questão quanto na "oxigenação" propiciada por tal participação nos processos objetivos que mais se aproximam - ao menos no aspecto negativo - à atividade legislativa, parece possível aplicá-los aos procedimentos administrativos de índole normativa.

Embora fosse desejável a criação de diploma legal contemplasse e regulasse detidamente a utilização desse mecanismo para a Administração Pública, deve-se destacar que parece possível, desde logo, utilizá-lo no âmbito das agências reguladoras independentes. Além de já haver normas de agências específicas que contemplam mecanismo semelhante ${ }^{510}$, a Lei de Processo Administrativo (Lei no 9.784/99) estabelece, em seu artigo 33, que "Os órgãos e entidades administrativas, em matéria relevante, poderão estabelecer outros meios de participação de administrados, diretamente ou por meio de organizações e associações legalmente reconhecidas". Defende-se que figura semelhante a um "amicus curiae" inclui-se dentre esses "outros meios" que a lei coloca à

\footnotetext{
${ }^{508}$ Essa parece ser o título da intervenção da Comissão de Valores Mobiliários - CVM e do Conselho Administrativo de Defesa Econômica - CADE em processos judiciais que tratem de temas relacionados ao mercado de valores mobiliários e à aplicação da legislação antitruste. Nos termos do art. 31 da Lei $n^{\circ}$ 6.385/76, "Nos processos judiciais que tenham por objeto matéria incluída na competência da Comissão de Valores Mobiliários, será esta sempre intimada para, querendo, oferecer parecer ou prestar esclarecimentos, no prazo de 15 (quinze) dias a contar da intimação" e, conforme o art. 89 da Lei no 8.884/94, "Nos processos judiciais em que se discuta a aplicação desta Lei, o CADE deverá ser intimado para, querendo, intervir no feito na qualidade de assistente".

${ }^{509}$ Supremo Tribunal Federal, Ação Direta de Inconstitucionalidade n ${ }^{\circ} 3.045$, Pleno, Relator Ministro Celso de Mello, DJ 01.06.2007

${ }^{510}$ Por exemplo, o art. $8^{\circ}, \S 3^{\circ}$, II, da Lei no $6.385 / 76$, segundo o qual a Comissão de Valores Mobiliários CVM pode "convocar, a seu juízo, qualquer pessoa que possa contribuir com informações ou opiniões para o aperfeiçoamento das normas a serem promulgadas."
} 
disposição da Administração Pública em geral (e das agências reguladoras independentes em particular), de modo que poderia ser utilizada, com relativa facilidade, nos procedimentos de produção normativa levados a efeito pelas agências reguladoras independentes. $^{511}$

Entende-se que a procedimentalização e a participação que deve a acompanhar contribuem para a minimização dos riscos da captura nas três modalidades elencadas ao início. Primeiro, aumenta a transparência da atividade; segundo, implica um reforço da autoridade da agência (mormente no sentido em que a procedimentalização pode ser encarada como forma de legitimação da atuação estatal) e, por fim, permite que a agência tenha acesso a maiores e melhores informações do que aquelas que ela teria se não tivesse submetido as normas a mecanismos de participação.

\section{b.2) Fundamentação das decisões}

Ao final do processo administrativo (individual ou normativo), as agências reguladoras independentes deverão proferir uma decisão. Relativamente aos processos administrativos individuais, o dever de decidir e de que essa decisão esteja devidamente motivada decorre não só do Texto Constitucional, mas está disciplinada em diferentes disposições da Lei de Processo Administrativo (artigos 48 a 50). Aqui, aplicam-se todas as lições tradicionais de Direito Administrativo, no sentido de que a motivação apresentada precisa ser explícita, clara e congruente. Aplica-se, também, a teoria dos motivos determinantes, expressa na idéia de que "Cuando un agente público expresa, en el acto

\footnotetext{
$511 \mathrm{O}$ uso da medida aqui mencionada teria especial relevância quando a regulação tivesse origem em sugestão formulada pelo grupo de regulados. Se é correta a ideia de que o fato de a proposta normativa ter origem em um dos regulados não é motivo para deixar-se de apreciar a questão (e nem para a invalidar a futura norma que tenha essa origem), é inafastável que a agência reguladora precisará de outras fontes de informação para poder contrastar a proposta que lhe é apresentada. Nesse sentido, é ilustrativa a recomendação de 31.05.1996, do Conselho de Reforma do Estado. Nesse documento, que sugeria a modelagem geral das agências reguladoras independentes, expressamente se mencionou que os anteprojetos de lei deveriam contemplar normas que garantissem a independência decisória da agência. Dentre elas, "a vedação de decisões fundadas exclusivamente em informações trazidas pelos interessados e a faculdade do ente regulador contratar de fontes independentes o fornecimento de informações técnicas no Brasil e no exterior, assim como de consultoria externa, a critério do colegiado" (MINISTÉRIO DA ADMINISTRAÇÃO Federal e Reforma Do Estado. O Conselho de Reforma do Estado - Cadernos MARE da Reforma do Estado $n^{o}$ 8. Brasília: MARE, 1997, p. 29. Disponível em: <http://www.planejamento.gov.br/secretarias/ upload/Arquivos/publicacao/seges/PUB_Seges_Mare_caderno08.PDF>).
} 
mismo, los motivos que le han hecho obrar, estos motivos, por lo mismo que están expresados em el acto, se consideran, en principio, determinantes". ${ }^{512}$

No que se refere a atos normativos, tem-se que o dever de motivação também se impõe. Primeiro, ele se coloca quando do recebimento das manifestações formuladas pelos interessados. Tal como exposto acima, a legislação pátria exige que se forneça resposta fundamentada a cada uma das intervenções. A essas respostas, aplicam-se os requisitos de motivação tradicionais dos atos administrativos individuais antes referidos. Porém, esse dever não se esgota nesse momento. Quando da prolação da decisão - que, aqui, implica a edição do ato normativo - é necessária a apresentação da fundamentação que embasa a escolha levada a efeito pela Administração. Essa fundamentação deve compor os "considerandos" da norma, que também ficam sujeitos à observância dos deveres de clareza e congruência na exposição. Essa "exposição de motivos" deve sustentar, de modo consistente, as normas editadas e as finalidades que pretendem ser atingidas por meio dos atos normativos. Em outras palavras: os "considerandos" devem mostrar, de modo nítido, que as normas que ali se editam são meios adequados para a obtenção dos fins a que se visam.

Note-se que, aqui, se partilha da opinião de HuMBERTo Ávila no sentido de que não se exige da Administração em geral (e da agência reguladora independente em particular) “o dever de escolher o 'mais intenso', 'melhor' e 'mais seguro' meio para atingir o fim", bastando que selecione "um meio que 'simplesmente' promova o fim". 513 Isso tanto porque nem sempre é dado à Administração conhecer todos os meios para atingir certo fim, a ponto de conseguir identificar aquele que seja "melhor", "mais intenso" ou "mais seguro". Na medida em que a obtenção de informações completas normalmente é inviável, sempre se tem a possibilidade de que a solução ótima sequer tenha sido cogitada. Não bastasse isso, a edição de normas é uma atividade prospectiva, em que se busca a alteração de comportamentos futuros. Os efeitos concretos da existência da norma só podem ser verificados a posteriori, para os quais podem contribuir fatos e circunstâncias sobre as quais não se tinha condições de cogitar no momento da edição normativa.

\footnotetext{
${ }^{512}$ GASTON JèZE. Principios generales del derecho administrativo. vol. III, Buenos Aires: Editorial Depalma, 1949 , p. 232.

513 "Moralidade, Razoabilidade e eficiência na atividade administrativa". Revista Eletrônica de Direito do Estado. vol. 4, out-dez 2005, p. 22. Disponível em: 〈http://www.direitodoestado.com.br〉. Último acesso em: 20.06.2008.
} 
Porém, e ainda na trilha de HumBERTo ÁvilA, o fato de não se exigir da Administração a seleção do melhor meio à consecução de dado fim não lhe concede a possibilidade de escolher o "pior" meio, o "menos intenso" ou "menos seguro". 514 Afinal, “quando a administração emprega um meio que, embora adequado à realização de um fim, não serve para atingi-lo minimamente em termos quantitativos, qualitativos e probalísticos, o fim não é promovido satisfatoriamente" ${ }^{, 515} \mathrm{e}$ "Escolher um meio adequado para promover um fim, mas que promove o fim de modo insignificante, com muitos efeitos negativos paralelos ou com pouca certeza, é violar o dever de eficiência administrativa". 516

Essa ordem de considerações permite afirmar que, embora a não-obtenção do resultado ótimo na realização dos fins buscados não seja suficiente para criticar a norma regulatória, é necessário que o órgão regulador demonstre que, dentre as soluções que se afiguravam possíveis, a escolhida era satisfatória, especialmente se comparada com as alternativas disponíveis no momento de edição da norma. Por isso, entende-se que, além de demonstrar a adequação entre os meios previstos na norma regulatória e o fim por ela visado, a fundamentação também deve contemplar as razões que implicaram a escolha de determinada decisão em detrimento das demais que também se afiguravam como plausíveis para a situação em exame. É certo que haverá algumas situações em que a escolha se dá entre opções indiferentes (tanto faz "A" ou "B") ou opções incomparáveis (pode ser "A" ou "B" porque não há critérios que permita aproximá-las em uma comparação). Porém, essas circunstâncias também devem estar explicitadas na fundamentação da decisão. A fundamentação que observe essas características amplia a transparência das atividades desenvolvidas pelas agências reguladoras e, nessa medida, pode contribuir na prevenção do risco de captura.

\subsubsection{O controle das atividades regulatórias}

Ao lado de reforçar a autoridade das agências reguladoras e de ampliar o volume de informações disponíveis para o exercício da regulação, as medidas acima sugeridas tendem a delinear a ação regulatória e a ampliar a transparência das atividades das agências reguladoras independentes. Esse maior "confinamento" da atuação das agências somado ao acesso e à divulgação das informações sobre a atividade que desempenham permite que as agências se tornem mais responsabilizáveis (accountable) e

\footnotetext{
514 "Moralidade, Razoabilidade e eficiência na atividade administrativa". Ob. cit., p. 23.

515 "Moralidade, Razoabilidade e eficiência na atividade administrativa". Ob. cit., p. 23.

516 "Moralidade, Razoabilidade e eficiência na atividade administrativa". Ob. cit., p. 24.
} 
que se desenvolvam mecanismos de controle a incidir sobre as agências. Aliás, o esforço para se cogitar de mecanismos que permitam conhecer mais e melhor a atividade desempenhada pela agência culmina na ampliação da accountability e na possibilidade de controle de tais entes.

A partir dessa afirmação, uma indagação se coloca de imediato: afinal, a característica fundamental das agências reguladoras não é a de serem elas entes independentes (ou, quando menos, dotados de autonomia reforçada)? Levar a efeito o controle das agências não implicará o comprometimento dessa característica que lhes é essencial?

Embora, à primeira vista, "controle" e "autonomia" sejam noções antitéticas, a depender do "tipo" de controle eleito e dos "mecanismos" adotados para adotá-lo parece possível superar essa antinomia. Nessa tentativa, e em contraposição a medidas de controle hierárquico ${ }^{517}$, o presente trabalho cogita a possibilidade de que a agência reguladora independente seja submetida a uma supervisão permanente exercida simultaneamente por uma multiplicidade de atores. Para implementar esse controle, entende-se mais adequado a utilização de mecanismo próximo ao de "alarme de incêndio" em vez de um controle por "patrulhamento", isto é, prefere-se o estabelecimento de um sistema de regras, processos e práticas que permitam detectar as eventuais violações aos objetivos regulatórios e, a partir de tal constatação, cogitar de atuações de controle da regulação. ${ }^{518}$ No exercício dessa supervisão permanente, teriam relevância os papéis

\footnotetext{
${ }^{517}$ Empresta-se, aqui, a definição de controle hierárquico de REGINA SILVIA PACHECO, segundo quem "O controle hierárquico baseia-se na relação de autoridade que se estabelece entre o nomeador e o nomeado; é fortemente sustentado peno paradigma clássico da burocracia, que pressupõe autoridade única e relações verticais de comando e controle" ("Regulação no Brasil: desenho das agências e formas de controle". Revista Eletrônica sobre a Reforma do Estado. Salvador, $\mathrm{n}^{\circ}$ 7, set-nov 2006, p 15. Disponível em: www.direitodoestado.com.br. Último acesso em: 20.06.2009).

${ }^{518}$ As figuras do mecanismo de controle por "patrulhamento" e o de controle por "alarme de incêndio" foram cunhadas por MATHEW MCCUBBINS e THOMAS SCHWARTZ, no contexto norte-americano, ao examinarem o controle do Congresso sobre as delegações que ele efetuava em favor do Executivo (inclusive, das agências reguladoras). Segundo esses AUTORES, relativamente ao controle por patrulhamento, "Analogous to the use of real police patrols, police-patrols oversight is comparatively centralized, active, and direct: at its own initiative. Congress examines a sample of executive-agency activities, with the aim of detecting and remedying any violations of legislative goals and, by its surveillance, discouraging such violations" ("Congressional oversight overlooked: police patrols versus fire alarms". American Journal of Political Science. vol. 28 (1), feb. 1984, p. 166). Por sua vez, o controle por alarme de incêndio "Analagous to the use of real fire alarms, fire-alarms oversight is less centralized and involves less active and direct intervention than police-control oversight: instead of examining a sample of administrative decisions, looking for violations of legislative goals, Congress establishes a system of rules, procedures, and informal practices that enable individual citizens and organized interest groups to examine administrative decisions (sometimes in prospect) to charge executive agencies with violating congressional goals, and to seek remedies from agencies, courts and Congress itself" ("Congressional oversight overlooked: police patrols versus fire
} 
exercidos pelos cidadãos, pelo Poder Legislativo e pelo Poder Judiciário (que se colocam ao lado do Poder Executivo Central).

Os cidadãos, quando passam a participar dos procedimentos de elaboração normativa das agências reguladoras, passam a ter acesso a informações necessárias não só para compreender a medida regulatória editada, mas também para se contrapor a ela, na hipótese de entendê-la ilegal ou inconstitucional. E, para isso, pode acionar o Poder Legislativo, o Poder Judiciário e a cúpula do Poder Executivo.

O Poder Legislativo tem a possibilidade de criar, ex ante, os instrumentos que permitirão essa supervisão, especialmente por meio da definição precisa dos objetivos regulatórios e da utilização de meios de validação de cunho finalístico. Depois de exercida a competência legislativa propriamente dita, o Legislativo - de ofício ou em decorrência de requerimento dos cidadãos - pode exercer a competência fiscalizatória que lhe é peculiar. Por meio da convocação prevista no artigo 50 da Constituição Federal ("A Câmara de Deputados e o Senado Federal, ou qualquer de suas Comissões, poderão convocar Ministro de Estado ou quaisquer titulares de órgãos diretamente subordinados à Presidência da República para prestarem, pessoalmente, informações sobre assunto previamente determinado, importando em crime de responsabilidade a ausência sem justificação adequada") e da competência que a Constituição lhe confere para "sustar os atos normativos do Poder Executivo que exorbitem do poder regulamentar ou dos limites da delegação legislativa" (artigo 49, V, da Constituição Federal). Porém, e especialmente com

alarms”, p. 166). Segundo os autores, normalmente opta-se pelo uso do segundo modelo porque tende a ser menos custoso (especialmente em relação ao tempo despendido para o exercício do controle). De toda a forma, dez anos depois, MATHEW MCCUBBINS (em co-autoria com ARTHUR LUPIA) é cético em relação à eficácia do sistema “alarme de incêndio" (MATHEW MCCUBBINS E ARTHUR LUPIA, "Learning from oversight: fire alarms and police patrols reconstructed". Journal of Law, Economics \& Organization. vol. 10, 1994, p. 96-125). Nesse novo texto, ele reconhece que há ocasiões - especialmente diante da diferença informacional entre "quem aciona o alarme" (normalmente, aqueles que têm interesse no ato regulatório) e "quem recebe o sinal de alarme" (o Congresso) - em que o controle não funcionará adequadamente, pois o Congresso não tem meios para diferenciar "falsos alarmes" de "alarmes verdadeiros". E, então, pode ser que o sistema não propicie o controle que dele se espera. Assim, quando se fala que o presente trabalho cogita de um sistema próximo ao mecanismo "alarme de incêndio", a afirmação precisa ser mais bem explicada. Cogita-se dessa aproximação no sentido de se conceber um sistema que contempla uma rede composta por diferentes elementos que permitem detectar desvios e que acionam a atuação de diferentes atores, viabilizando um controle sem controladores diretos e imediatos. (a respeito, ver REGINA SILVIA PACHECO, "Regulação no Brasil: desenho das agências e formas de controle". Ob. cit., p. 15). Porém, entende-se que o "acionamento dos alarmes" pode ser levado a efeito por qualquer dos envolvidos no processo regulatório (os cidadãos e interessados, mas também o Legislativo e o Executivo por eles mesmos e com recurso ao Judiciário). Assim, há alguma diferença entre o que aqui se defende e a idéia original de controle por "sistema de alarme". Enquanto originalmente o "sistema de alarme" centra-se na atividade dos cidadãos e grupos de interesse para "acionar" o alarme; aqui se entende que os responsáveis pelo exercício do controle têm conduta ativa e podem, de pronto, levar a efeito o controle que esteja a eles atribuído. 
relação a esse último instrumento, o seu uso só se revelará eficiente se houver a prévia definição de objetivos regulatórios. Isso porque, diversamente do veto legislativo norteamericano (posteriormente considerado inconstitucional pela Suprema Corte), “o poder conferido ao Congresso brasileiro (...) não deve ser exercido com base em juízos de oportunidade e de conveniência, mas sim em vista os limites objetivos das competências normativas outorgadas pela lei". ${ }^{519}$ Se é assim, não havendo precisa definição dos objetivos normativos, não há como se precisar os limites das competências normativas outorgadas às agências (pressuposto inafastável para que a sustação de atos regulamentares possa se operar).

O Poder Judiciário - por meio de provocação dos cidadãos individualmente considerados ou em sede de ações coletivas - poderá igualmente promover o controle das medidas regulatórias. Nesse contexto, avulta a relevância da exigência de fundamentação das decisões regulatórias. Ao lado de promover evidente desincentivo para que decisões arbitrárias sejam adotadas, a ausência ou a motivação inadequada permite que o Judiciário controle as medidas regulatórias. Mais que isso: permite que, a despeito da falta de especialização técnica do Judiciário, desenvolva-se um mecanismo de controle judicial pautado em exame de estrita legalidade (exame da motivação da medida sob exame), por meio do qual "Juízes podem exigir e avaliar explicações detalhadas das decisões regulatórias sem substituir os juízos técnicos e políticos das agências pelos seus". 520

Por fim, há de se examinar o papel reservado ao Chefe do Poder Executivo. Esse é o tema mais delicado a ser enfrentado, especialmente quando se tem em conta a realidade brasileira (e a tendência que nela se revela de concentração de competências no Poder Central) e a pretensão, já antes anunciada, de afastar o puro e simples controle hierárquico. Em momento anterior ao exercício das competências regulatórias pelas agências reguladoras, o Poder Central detém a possibilidade de definir as linhas gerais das

\footnotetext{
${ }^{519}$ SÉRGIO VARELLA BRUNA, Agências reguladoras: poder normativo, consulta pública, revisão judicial. Ob. cit., p. 260. Esse instrumento conferido ao Congresso implica, portanto, juízos objetivos e de legalidade. Não envolve exercício de poderes discricionários e a sua utilização está sujeita a controle judicial (ver, a respeito, ANNA CÂNDIDA DA CUNHA FERRAZ. Conflito de poderes - O poder congressual de sustar os atos normativos do Poder Executivo. São Paulo: RT, 1994, p. 91-95).

${ }^{520}$ CASS SunSteIn, "O constitucionalismo após o New Deal". Ob. cit., p. 169.
} 
políticas públicas, fixando os elementos básicos do marco regulatório do setor. ${ }^{521}$ Tal como afirma Floriano de AZEVEdo MARQues Neto,

Importante é termos claro, na medida em que dotamos os órgãos reguladores de independência e de amplas competências de intervenção em um determinado setor, não se pode pretender atribuirlhes também a competência para conceber e estabelecer as políticas públicas setoriais. Se assim fosse, aí sim estaria em risco o princípio democrático, porquanto interditada aos representantes eleitos a possibilidade de definir os objetivos e prioridades a serem concretizados pela atividade regulatória. Os órgãos reguladores não são instância institucional de definição de políticas. São sim espaços e instrumentos para efetivação destas, previamente definidas pelo executivo e pelo legislativo (eventualmente até com a participação e o suporte técnico do órgão regulador, mas fora do campo decisório deste). ${ }^{522}$

Trata-se de instrumento de extrema relevância, capaz de delimitar, ex ante, o modo e o campo de atuação das agências reguladoras.

Relativamente ao controle a posteriori, entende-se que o Poder Central deve levar a efeito um controle de legalidade, por meio do contraste entre a medida regulatória (que deverá ser devidamente motivada e demonstrar o meio pelo qual pretende alcançar os objetivos definidos nas políticas públicas e na lei que fixa os objetivos regulatórios), as previsões normativas gerais (fixadas em lei) e as previsões normativas contempladas na definição das políticas públicas (normalmente fixadas por decreto do Presidente da República). Nesse sentido, avulta a relevância da motivação e do controle que pode ser por ela exercido. ${ }^{523}$

${ }^{521}$ Essa competência está expressa na Lei n. ${ }^{0}$ 9.472/98, cujo artigo 18 fixa as atribuições do Chefe do Executivo relativamente ao setor de telecomunicações (sobre a amplitude desse dispositivo, ver o texto de GuSTAVO BINEMBOJM e ANDRÉ RODRIGUES CYRINO. "Entre política e expertise: a repartição de competência entre o Governo e a ANATEL na Lei Geral de Telecomunicações". Revista Eletrônica de Direito Administrativo Econômico. vol. 16, Salvador, nov-jan 2009. Disponível em: <www.direitodoestado.com. br/redae.asp>. Último acesso em: 8.7.2009). Note-se que a possibilidade de o Chefe do Executivo traçar as linhas gerais da política pública do setor sob regulação também se aplica aos setores que não contam com disposição similar à contemplada na Lei Geral de Telecomunicações. Ao examinar os limites da competência normativa à Agência Nacional de Telecomunicações, o SUPREMO TRIBUNAL FEDERAL deu interpretação conforme a dispositivo de lei consignando que "nada impede que a agência tenha funções normativas, desde, porém, que absolutamente subordinadas à legislação e, eventualmente, às normas de segundo grau, de caráter regulamentar, que o Presidente da República entenda baixar." Esse entendimento foi adotado porque "nada pode subtrair da responsabilidade do agente político, que é o Chefe do Poder Executivo, a ampla competência reguladora da lei de telecomunicações". Assim, deu-se "interpretação conforme para enfatizar que os incisos IV e X referem-se a normas subordinadas à lei e, se for o caso, aos regulamentos do Poder Executivo" (Supremo Tribunal Federal. Medida Cautelar na Ação Direta de Inconstitucionalidade n. ${ }^{\circ}$ 1668, Relator Ministro MARCo AURÉLIO, DJ 16.4.2004 - os trechos aqui citados foram extraídos do voto do Ministro SEPÚlVEDA PERTENCE, relativamente ao exame dos incisos IV e X do art. 19 da LGT). Note-se que foram examinados os limites abstratos das competências normativas outorgadas às agências, não havendo especificidade que impeça aplicar esse entendimento a outras agências reguladoras independentes.

${ }^{522}$ Agências Reguladoras: instrumentos do fortalecimento do Estado. Ob. cit., p. 41-42.

${ }^{523}$ Ver item 5.3.2, b, acima, em que se sustenta que a motivação deve revelar o emprego de meio satisfatório para atingir os fins previstos pela lei e pelas políticas públicas. 
Isso, contudo, não autoriza que o Chefe do Poder Executivo interfira no exercício próprio da discricionariedade da agência reguladora e revise o ato regulatório ou pratique-o em lugar do regulador. Também não é possível que, casuisticamente, altere os meios fixados pelas normas regulatórias como formas para atingir os objetivos fixados em lei e pelas políticas públicas ou modifique o momento de implementação das medidas por ela definido. Como bem destaca CASS SUNSTEIN relativamente à atuação do Office and Management and Budget (OMB) - órgão da Presidência da República norte-americana sobre as agências reguladoras, "o controle pelo OMB não deve atropelar o papel da agência como a última autoridade incumbida da decisão". 524

Assim, e se por um lado é possível que haja restrição da discricionariedade outorgada à agência (por meio da prévia definição de objetivos regulatórios e das políticas públicas do setor); por outro, no exercício da parcela de discricionariedade que lhe é conferida, não é possível cogitar acerca de interferência direta (nem mesmo pelo Chefe do Executivo). Caso não seja assim, instituir-se-á um controle hierárquico. E “controle hierárquico não garante responsabilização, e sim alinhamento". 525

Em suma: por meio dos mecanismos acima cogitados pretende-se viabilizar o controle da atividade da agência - a ser exercido pelos três Poderes, com a contribuição dos cidadãos em geral -, em um sistema de supervisão permanente e simultâneo que não se confunde com o controle hierárquico, mas que permite identificar, de modo indubitável, que a agência reguladora está sujeita a controle. Como é evidente, a maior sujeição a controle reduz o risco de captura, pois cria novas instâncias de apreciação, que podem afastar as medidas adotadas em situações de comprometimento da imparcialidade ou em que tenda a prevalecer a visão de grupos específicos.

\footnotetext{
524 “O constitucionalismo após o The New Deal”. Ob. cit., p. 162.

525 REgina Silvia PACHECO, "Regulação no Brasil: desenho das agências e formas de controle”, Ob. cit., p. 16.
} 


\section{CONCLUSÃO}

As agências reguladoras independentes surgiram nos Estados Unidos como estruturas organizativas que viabilizariam a estratégia de intervenção do Estado sobre o domínio econômico. Ao desenvolverem as atividades a elas atribuídas, estudos de ciência política e de ciência econômica identificaram a ocorrência de uma espécie de captura das agências reguladoras independentes. Por esse termo, normalmente se designa o fato de que, no exercício da regulação, essas agências privilegiariam o interesse dos regulados em detrimento do interesse público que deveriam tutelar. $\mathrm{O}$ presente trabalho pretendeu analisar esse problema específico e, a partir das investigações nele feitas, torna-se possível apresentar algumas conclusões.

A primeira envolve o próprio núcleo duro do problema da captura.

Entende-se que, na atualidade, não é possível compreender o tema como o comprometimento do interesse público em detrimento do interesse privado. Se, no momento em que os primeiros estudos identificaram a ocorrência de captura ainda era possível diferir, com alguma precisão, interesse público e interesse privado, na atualidade, essa distinção é extremamente difícil (quiçá, impossível) de ser levada a efeito. Nos dias atuais, a noção de interesse público é, em grande parte dos casos, construída casuisticamente, pela própria Administração ou pelo responsável pelo exercício da regulação, o que impede a sua identificação ex ante. Por isso, entende-se adequado que o problema da captura seja tomado como o comprometimento da imparcialidade da autoridade responsável pelo exercício da regulação econômica.

A segunda ordem de conclusões está relacionada às circunstâncias fáticas aptas a gerar esse desvio e à razão de as agências reguladoras independentes serem organizações mais sensíveis à ocorrência de captura.

Quanto às circunstâncias, tem-se que o exercício de competências discricionárias é conditio sine qua non para a ocorrência de captura. Se as competências outorgadas ao regulador são integralmente vinculadas, não há opções dadas ao regulador e o problema não se coloca.

As agências reguladoras independentes seriam mais suscetíveis à ocorrência de captura porque, diante da autonomia de que são dotadas, há condições propícias para 
que se forme um espaço de frouxidão, em que essas competências são exercidas longe do escrutínio público. Nesse espaço, se o desejarem, os responsáveis pela regulação podem atuar estrategicamente, buscando segurança e estabilidade (tal como enuncia a teoria do ciclo de vida das agências reguladoras) ou visando auferir algum benefício futuro (prestígio ou colocação profissional, por exemplo).

Porém, além de situações em que há a atuação estratégica dos responsáveis pelo exercício da regulação, a característica das situações concretas em que se dá o exercício da regulação também facilita a ocorrência do problema.

A uma, a regulação ditada por agências reguladoras independentes envolve, em regra, a atuação sobre um setor econômico específico. Normalmente, os agentes econômicos que nele atuam constituem um grupo formado por poucos integrantes, com interesses coesos. Portanto, esses agentes têm interesse e condições de se organizarem com relativa facilidade para acompanhar cotidianamente a atividade das agências reguladoras. Todavia, o mesmo não ocorre com interesses mais amplos, que perpassam os eventuais usuários de certo bem ou serviço regulado. Os custos de organização de grandes grupos são altos e os eventuais benefícios que dela derivam normalmente não os compensam. Assim, a regra é existir um desequilíbrio na representação de interesses perante as agências reguladoras, que pode redundar na tendência de que os interesses dos agentes econômicos sejam mais bem representados e, por conseguinte, privilegiados.

A duas, é inafastável a existência de assimetria informacional entre regulador e regulado. Essa assimetria pode abranger o conhecimento técnico relativo ao setor, mas envolve, especialmente, informações fáticas necessárias ao exercício da regulação. Esse dado também facilita a ocorrência de captura, pois muitas vezes o exercício da regulação tem como ponto de partida a informação fornecida pelo próprio regulado.

A três, a atuação das agências reguladoras independentes tende a justificarse a partir de parâmetros estritamente técnicos. Para sua própria manutenção, é fundamental que as normas por elas editadas sejam respeitadas ou que, pelo menos, não sejam deliberadamente ignoradas pelos destinatários. Caso isso venha a ocorrer, a autoridade das agências estará completamente aniquilada. $\mathrm{Na}$ medida em que os destinatários das normas regulatórias tendem a ser os grupos regulados, parece mais fácil 
obter a adesão às normas a partir da edição de regras que se coadunem com os interesses desses destinatários. E, assim, esse dado facilita a ocorrência de captura.

Desse modo, e em termos sucintos, é possível afirmar que as agências reguladoras independentes são mais suscetíveis à ocorrência de captura porque $(i)$ nelas há lugar para a formação de espaços de frouxidão, nos quais os responsáveis pela regulação podem atuar estrategicamente; (ii) as características dos grupos formados por agentes econômicos regulados permitem que se organizem mais facilmente; (iii) é inafastável a assimetria informacional entre o regulador e regulados, sendo que, muitas vezes, a informação necessária à regulação é detida, tão-somente, pelo grupo de regulados; e (iv) as agências precisam afastar a possibilidade de que as normas por elas editadas sejam simplesmente desconsideradas pelos destinatários. Enquanto na primeira situação há uma conduta voluntária e consciente do regulador no sentido de se afastar da regulação adequada ao caso concreto com vistas a tutelar interesses pessoais, nas hipóteses restantes essa dado não ocorre necessariamente, ou seja, nos três últimos casos, é possível que o regulador esteja bem-intencionado (e a captura ocorra inconscientemente).

A terceira conclusão deste trabalho é a de que as características da interação Estado-sociedade existentes na realidade nacional facilitam a ocorrência de captura.

No Brasil, a dificuldade de se conhecer as normas vigentes (especialmente diante do número de diplomas normativos que disciplinam o mesmo tema) e o privilégio de contactos informais de negociação facilitam o aparecimento de espaços de frouxidão nos quais a captura pode ocorrer. Se é correto afirmar que a criação de canais institucionalizados de participação - concretizados especialmente por meio da previsão de realização de audiências e consultas públicas - permitiria reduzir esses espaços, é igualmente certo que essa solução depende da participação espontânea dos cidadãos. E, aqui, sempre se privilegiaram soluções tomadas a partir de decisões estatais em detrimento de tais manifestações espontâneas.

Depois, não se pode olvidar que um dos motivos para a criação de agências reguladoras independentes no Brasil foi, justamente, a tentativa de viabilizar a credibilidade institucional de que o país carecia. Essa "missão" assumida pelas agências reguladoras independentes torna ainda mais problemática as situações em que se ignoram 
os mandamentos da agência reguladora independente. Afinal, se as agências reguladoras foram criadas com a finalidade de conceder um arcabouço institucional mínimo para viabilizar os processos de liberalização, desestatização e privatização, sua eventual desautorização coloca em foco não só as limitações dessas organizações estatais, mas também põe em xeque o sucesso daqueles processos. Portanto, em âmbito nacional, há motivos para afirmar que as agências reguladoras independentes são sensíveis à possibilidade de desconsideração da norma regulatória.

Por fim, a preponderância do Poder Executivo vivenciada na realidade brasileira permite que se cogite de um tipo sui generis de captura, consistente no uso da regulação técnico-econômica pelo Poder Central. Esse dado é especialmente plausível quando se tem em conta que o modo de criação de normas no Estado Brasileiro tende a privilegiar soluções ad hoc em prejuízo de ações planejadas e que têm em mira metas de médio e longo prazo.

A quarta conclusão do presente trabalho envolve a caracterização do problema da captura como uma decorrência do exercício da regulação em uma sociedade complexa.

Depois de examinado o problema da captura sob o viés fático, o presente trabalho pretendeu verificar de que modo o sistema jurídico pode compreender o problema da captura. A partir dessa investigação, conclui-se que, sob o ângulo jurídico, o problema da captura pode ser interpretado de três formas diferentes: (i) como expressão do dilema acerca do "controle do controlador"; (ii) como sintoma das dificuldades relacionadas ao exercício da regulação na sociedade complexa; e (iii) como um resultado "não-querido" que acompanha medidas adotada em reação às dificuldades relacionadas ao exercício da regulação estatal.

Na primeira leitura, o problema da captura é expressão de um paradoxo inerente ao próprio direito e que diz respeito a sua circularidade. Ao fim, sempre se coloca a indagação de quem controlará aquele responsável pela palavra final acerca de determinada situação jurídica. Na medida em que as agências reguladoras independentes não se vinculam hierarquicamente a outra autoridade, é até mesmo intuitivo que a questão se coloque em relação a elas. 
Na segunda leitura, colocam-se as dificuldades de interação entre o sistema jurídico e os demais subsistemas sociais. Na medida em que o direito é o instrumento usual para a regulação dos demais sistemas sociais, é possível que, em certas situações, ocorra uma sobresocialização do direito, de forma que ele seja "colonizado" pelos subsistemas sociais que visa a regular. No âmbito da regulação econômica, o problema da captura em tudo se aproxima dessa situação. Em vez de fixar as normas que devem ser observadas pelos outros subsistemas sociais (na hipótese sob análise, pelo sistema econômico), a regulação é que acaba por ser editada de acordo com os parâmetros ditados por esses outros subsistemas sociais (no caso sob exame, pelo sistema econômico).

$\mathrm{Na}$ terceira leitura, o problema da captura emerge como uma "externalidade" (isto é, como um resultado não-desejado) decorrente do uso das agências reguladoras independentes como instrumento de reação às dificuldades enfrentadas no exercício da regulação estatal. Em meados da década de 1990, recorreu-se à criação de agências reguladoras independentes como forma de fazer frente à complexidade e à variabilidade das matérias submetidas à regulação. Esse recurso trouxe consigo a criação de organizações que, a despeito de sua natureza estatal, exercem ampla discricionariedade em locus não sujeito aos controles hierárquicos previstos para a Administração Pública Tradicional. Criam-se, assim, condições para que o problema da captura venha a ocorrer, mesmo que esse efeito não fosse previsto ou desejado quando da instalação das agências reguladoras independentes.

A quinta conclusão é a de que o problema da captura é um risco e, como tal, deve ser prevenido.

A captura não é uma característica inexorável da regulação. Envolve uma circunstância contingente porque, além da inexistência de um método que permita identificar - com segurança - que a edição de certa regra regulatória teve origem em eventual caso de captura, não é possível precisar, antecipadamente, como a regulação é lida pelo sistema econômico. ${ }^{526}$ Assim, não se pode afirmar, de antemão, que a regulação editada para dado caso concreto é derivada de uma situação de captura. Diante de tal ordem de circunstâncias, o problema da captura coloca-se como um risco (que pode, ou não, ocorrer) ligado à decisão de se regular determinado setor econômico por meio de agências reguladoras independentes.

\footnotetext{
${ }^{526}$ As diferentes possibilidades de leitura foram expostas no item 4.2. deste trabalho.
} 
Entende-se que esse risco deve ser prevenido porque a ocorrência da captura põe em causa os padrões democráticos que devem pautar a atuação estatal. Essas medidas preventivas devem ser ditadas pelo sistema político, cuja função é a de adotar decisões que vinculam a coletividade. Na medida em que essas decisões geralmente envolvem a edição de regras, a contribuição do sistema jurídico para minimizar o problema da captura envolve atuar a partir dessas regras e reputar como ilícitas as condutas que se desviem das normas em questão.

A sexta conclusão é a de que as teorias jurídicas que lidam com situações de "legalidade fronteiriça", embora possam contribuir para o tratamento do problema da captura, encontram limitações para tratar a questão.

Nesse contexto, são relevantes as teorias acerca do abuso de direito (especialmente no que concerne ao abuso do direito de demandar, à figura da sham exception aplicável no âmbito do direito antitruste e à possibilidade de se caracterizar eventual abuso de direito no exercício da liberdade de manifestação perante órgãos públicos) e do desvio de poder. Não obstante essas construções auxiliem no controle de condutas que poderiam configurar a ocorrência de captura, é fato que essas teorias permitem, tão-só, atuações ex post factum e somente incidentalmente atuarão sobre casos de captura.

Daí haver espaço para a sétima conclusão do presente trabalho, no sentido de que se deve cogitar de um ambiente institucional propício a reduzir a ocorrência de captura.

Esse ambiente institucional envolveria, primeiramente, a própria lei de criação das agências reguladoras independentes. Sugere-se que essa lei defina os objetivos regulatórios que devem ser perseguidos pelas agências reguladoras independentes, bem como outorgue competências às agências por meio de critérios de validação de cunho finalístico. Além de se viabilizar maior controle da atividade das agências, essas medidas permitem a ampliação da transparência da atividade regulatória (reduzindo, portanto, a possibilidade de formação de espaços de frouxidão), bem como reforçam a autoridade exercida pela agência reguladora (esse reforço ocorre não só porque se consegue visualizar a adequação da atuação da agência reguladora, como também porque a manutenção consecutiva de regulações constantemente contrastadas com as finalidades a que devem 
visar acabam por ampliar a credibilidade da organização responsável pelo exercício da regulação).

Depois, a procedimentalização da atividade regulatória também auxilia a criação desse ambiente institucional. Por meio de mecanismos de participação dos cidadãos - concretizados pela escorreita realização de audiências e consultas públicas e pela utilização de mecanismos similares à figura do amicus curiae, em que se instiga a participação de representantes da sociedade civil -, permite-se tanto o aumento da transparência da atividade regulatória (o que, como já dito, minimiza a ocorrência de captura) quanto se viabiliza que o regulador tenha acesso a informações em nível quantitativa e qualitativamente superior àquele que obteria sem essas medidas. Em sentido similar, o dever de fundamentação das decisões regulatórias - especialmente se tomado como dever expor as razões que levaram à escolha de determinada opção regulatória em detrimento de outras que também se afiguravam plausíveis - também amplia a transparência da atividade regulatória e, consequentemente, contribui para reduzir o risco de captura.

Ao final, é necessário destacar que não se ignoram as vantagens de se outorgar às agências reguladoras independentes o exercício da regulação, especialmente quando comparadas às organizações administrativas tradicionais. Ocorre que, a despeito das vantagens, o funcionamento das agências reguladoras independentes também apresenta desvios. Um deles é o risco de captura. Buscou-se examiná-lo em detalhes porque se compreende que o problema deve ser estudado e apreendido, a fim de que se construam soluções que tentem aprimorar o funcionamento das agências. Caso tais esforços não fossem empreendidos, ter-se-ia de concordar com os versos de FERNANDO PESSOA:

O prometido nunca será dado

Porque no prometer cumpriu-se o fado,

O que se espera, se a esperança e gosto,

Gastou-se no esperá-lo, e está acabado. ${ }^{527}$

527 “A 'sperança, como um fósforo inda aceso". 


\section{REFERÊNCIAS BIBLIOGRÁFICAS}

ABELLÁN, Joaquín. "Estudo preliminar". In: WEBER, Max. Sociología del poder: los tipos de dominación. Madrid: Alianza Editorial, 2007.

ABRAMOVAY, Ricardo. "Desenvolvimento e instituições: a importância da explicação histórica", 2001. Disponível em: <http://www.econ.fea.usp.br/abramovay/artigos cientificos.htm>. Último acesso em: 20.06.2009.

ACKERMAN, Susan-Rose. Corruption and government: causes, consequences, and reform.Cambridge: Cambridge Universtity Press, 1999.

ALESSI, Renato. Principi di diritto amministrativo. vol. I, $3^{\text {a }}$ ed., Milão: Dott A. Giuffrè Editore, 1974.

ALLEGRETTI, Umberto. L'Imparzialità Amministrativa. Pádua: CEDAM, 1965.

AMERICANO, Jorge. Do abuso do direito no exercício da demanda. $2^{\mathrm{a}}$ ed., São Paulo: Livraria Acadêmica, 1932, p. 52.

ARAGÃO, Alexandre Santos de. Agências reguladoras e a evolução do Direito Administrativo Econômico. $2^{\mathrm{a}}$ ed. Rio de Janeiro: Forense, 2003.

ARIÑO ORTIZ, Gaspar. La regulación econômica: teoría y práctica de la regulación para la competência. Buenos Aires: Editorial Ábaco de Rodolfo Depalma, s/d.

ARROW, Keneth J. Social Choice \& individual values. $2^{\text {nd }}$ ed., New Haven and London: Yale University Press, 1951.

ASCARELLI, Tullio. “O empresário (L’impreditore)” Trad. de Fábio Konder Comparato. Revista da Faculdade de Direito da Universidade de São Paulo, vol. 92, São Paulo 1997, p. 269-278.

AUTIN, Jean-Louis. "Du juge administratif aux autorités administratives indépendantes: un autre mode de régulation". Revue du Droit Public et de la Science Politique em France et a L'Étranger. vol. 5, Paris, 1988, p. 1213-1227.

ÁVILA, Humberto. "Repensando o 'princípio da supremacia do interesse público sobre o particular”. Revista Diálogo Jurídico. Salvador, vol. I (7), outubro-2001. Disponível em: <http://www.direitopublico.com.br>. Último acesso em: 01.09.2008.

. "Moralidade, Razoabilidade e eficiência na atividade administrativa". Revista

Eletrônica de Direito do Estado. vol. 4, out-dez 2005, p. 22. Disponível em: <http://www.direitodoestado.com.br>. Último acesso em: 20.06.2008.

AZEVEDO, Álvaro Villaça. Código Civil Comentado. vol. II, São Paulo: Atlas, 2003.

BALDWIN, Robert; CAVE, Martin. Understanding Regulation: theory, strategy and 
practice, New York: Oxford University Press, 1999.

BALMER, Thomas A. "Sham litigation and the antitrust laws". Buffalo Law Review. vol. 29, 1980, p. 39-71.

BANDEIRA DE MELlO, Celso Antônio. Curso de Direito Administrativo. 17 a ed., São Paulo: Malheiros, 2004.

BASTOS, Celso Ribeiro. Comentários à Constituição do Brasil. $2^{\circ}$ volume, São Paulo: Saraiva, 1989.

BECK, Ulbrich. La sociedade del riesgo global. Trad. de Jesús Alborés Rey. Madrid: Siglo Veintiuno de España editores, 2002.

BECKER, Gary. "A theory of competition among pressure groups for political influence". In: EKELUND, Robert B. (Ed). The foundations of regulatory economics. vol. II, Cheltenham: Edward Elgar, 1998, p. 173-202.

BERNSTEIN, Marver B. Regulating business by independent commission. Princeton: Princeton University Press, 1955.

BINENBOJM, Gustavo. As Agências Reguladoras Independentes e Democracia no Brasil”. Revista Eletrônica de Direito Administrativo Econômico. vol. 3, ago-out 2005, Disponível em: <www.direitodoestado.com.br>. Último acesso em: 1.6.2009.

BINEMBOJM, Gustavo e CYRINO, André Rodrigues. "Entre política e expertise: a repartição de competência entre o Governo e a ANATEL na Lei Geral de Telecomunicações". Revista Eletrônica de Direito Administrativo Econômico. vol. 16, Salvador, nov-jan 2009. Disponível em: <www.direitodoestado.com. br/redae.asp>. Último acesso em: 8.7.2009.

BLACK, Júlia. "Procedimentalizando a regulação: parte II". Trad. de Denise Vitale Mendes. In: MATTOS, Paulo Todescan L. (Org.). Regulação econômica e democracia: o debate europeu. São Paulo: Editora 34, 2006, p. 167-203.

"Constructing and Contesting Legitimacy and Accountability in Polycentric Regulatory Regimes". LSE - Law, Society and Economy Working Papers. vol. 2/2008, p. 8. Disponível em: <http://eprints.lse.ac.uk/23040 /1/WPS2008-02_Black.pdf>. Último acesso em: 15.10.2009

BOBBIO, Norberto. Diritto e Potere: saggi su Kelsen, Napoli: Edizioni Sccientifiche Italiane, 1992.

. O positivismo jurídico: lições de filosofia do direito. Trad. de Márcio Pugliesi, Edson Bini e Carlos E. Rodrigues. São Paulo: Ícone, 1995. 
Teoria geral da política: a filosofia política e as lições dos clássicos. Trad. de Daniela Beccaccia Versiani, Rio de Janeiro: Campus, 2000.

. O futuro da democracia. Trad. de Marco Aurélio Nogueira. São Paulo: Paz e Terra, 2000

Da estrutura à função: novos estudos de teoria do direito. Trad. de Daniela Beccaccia Versiani, Barueri: Manole, 2007.

BOBBIO, Norberto e VIROLI, Maurizio. Direitos e deveres na República: os grandes temas da política e da cidadania. Trad. de Daniela Beccaccia Versiani, São Paulo: Campus, 2007.

BRASIL. AGÊNCIA NACIONAL DE AVIAÇÃO CIVIL. Carta de renúncia de Milton Zuanazzi. Disponível em: <http://www.anac.gov.br/arquivos/pdf/Carta\%20 Milton\%20 Zuanazzi.pdf.> Último acesso em: 15.12.2008.

BRASIL. CONSELHO ADMINISTRATIVO DE DEFESA ECONÔMICA. Processo Administrativo $\mathrm{n}^{\circ}$ 08000.024581/1994-77, Relator Conselheiro RoBERTO AUGUSTO Castellanos PFEIFFer, DOU 9.2.2005.

BRASIL. CONSELHO ADMINISTRATIVO DE DEFESA ECONÔMICA. Averiguação Preliminar no 08012.005610/2000-81, Relator Conselheiro Luís FERNANDO SCHUARTZ, DOU 18.9.2006.

BRASIL. CONSELHO ADMINISTRATIVO DE DEFESA ECONÔMICA. Averiguação Preliminar nº 08012.005335/2002-67. Relator Conselheiro Luís FERNANDO SCHUARTZ, DOU 2.5.2007.

BRASIL. CONSELHO ADMINISTRATIVO DE DEFESA ECONÔMICA. Averiguação Preliminar $\mathrm{n}^{\circ}$ 08012.006076/2003-72, Relator Conselheiro CARLOS THADEU DeloRME PRADO, DOU 17.07.2007.

BRASIL. CONSELHO ADMINISTRATIVO DE DEFESA ECONÔMICA. Processo ${ }^{\circ}$ 08012.004484/2005-51, Relator Conselheiro FERnANDO DE MAGAlHÃES FurLAN (ainda não julgado).

BRASIL. MINISTÉRIO DA ADMINISTRAÇÃO FEDERAL E REFORMA DO ESTADO. O Conselho de Reforma do Estado - Cadernos MARE da Reforma do Estado $n^{o} \quad 8 . \quad$ Brasília: MARE, $1997 . \quad$ Disponível em: $<$ http://www.planejamento.gov.br/secretarias/upload/Arquivos/publicacao/seges/PUB_ Seges_Mare_caderno08.PDF>. Último acesso em: 20.06.2009.

BRASIL. MINISTÉRIO DO PLANEJAMENTO, ORÇAMENTO E GESTÃO. Boletim Estatístico de Pessoal. vol. 14, n. 160, ago-2009. Disponível em: 
http://www.servidor.gov.br/publicacao/boletim_estatistico/bol_estatistico_09/Bol160_ago2 009.pdf. Último acesso em: 1.10.2009.

BRASIL. SUPERIOR TRIBUNAL DE JUSTIÇA. 1 ${ }^{\mathrm{a}}$ Turma, Recurso Especial 207.484, Relator Ministro Humberto Gomes De BARros, Revista do STJ vol.135, Brasília, novembro 2000, p. 136-139

BRASIL. SUPERIOR TRIBUNAL DE JUSTIÇA. 1a Turma, Recurso Especial nº 414.402, Relator Ministro FrANCISCO FALCÃO, DJ 31.05.2004.

BRASIL. SUPERIOR TRIBUNAL DE JUSTIÇA. Recurso em Mandado de Segurança 18223/TO, $1^{\text {a }}$ Turma, Relator Ministro TEORI AlBINO ZAVASCKI, DJ 25.09.2006.

BRASIL. SUPREMO TRIBUNAL FEDERAL, Mandado de Segurança ${ }^{\circ}$ 8.693, Relator Ministro Ribeiro da Costa, DJ 20.08.1962.

BRASIL. SUPREMO TRIBUNAL FEDERAL, Pleno, Súmula nº 25. Aprovada na sessão plenária de 13.12.1963. Disponível em: www.stf.jus.br. Último acesso em: 1.10.2009.

BRASIL. SUPREMO TRIBUNAL FEDERAL, Pleno, Súmula nº 47. Aprovada na sessão plenária de 13.12.1963. Disponível em: www.stf.jus.br. Último acesso em: 1.10.2009.

BRASIL. SUPREMO TRIBUNAL FEDERAL. Pleno, Agravo Regimental em Ação Rescisória 1354, Relator Ministro CELSO dE Mello, DJ 06.06.1997.

BRASIL. SUPREMO TRIBUNAL FEDERAL. Pleno, Habeas Corpus 82.424, Relator Ministro MAURícIO CORRÊA, DJ 19.3.2004

BRASIL. SUPREMO TRIBUNAL FEDERAL. Pleno, Medida Cautelar na Ação Direta de Inconstitucionalidade n 1668, Relator Ministro MARCO AuRÉLIO, DJ 16.4.2004.

BRASIL. SUPREMO TRIBUNAL FEDERAL. Pleno, MS 24.268, Relator Ministro GILMAR MENDES, DJ 17.09.2004.

BRASIL. SUPREMO TRIBUNAL FEDERAL. Pleno. Medida Cautelar em Ação Direta de Inconstitucionalidade $n^{\circ}$ 1949, Relator Ministro SEPÚLVEDA PERTENCE, DJ 25.11.2005.

BRASIL. SUPREMO TRIBUNAL FEDERAL. Pleno, Ação Direta de Inconstitucionalidade 3.521, Relator Ministro EROS GRAU, DJU 16.03.2007.

BRASIL. SUPREMO TRIBUNAL FEDERAL. Ação Direta de Inconstitucionalidade $\mathrm{n}^{\circ}$ 3.045, Pleno, Relator Ministro Celso DE Mello, DJ 01.06.2007.

BRASIL. SUPREMO TRIBUNAL FEDERAL. Tribunal Pleno, Embargos de declaração nos Embargos de Divergência nos Embargos de Declaração no Agravo Regimental no Agravo de Instrumento $\mathrm{n}^{\circ}$ 567.171, Relator Ministro CELSO DE MELlo, DJe 05.02.2009.

BRASIL, SUPREMO TRIBUNAL FEDERAL, Argüição de Descumprimento de Preceito Fundamental 130/DF, Relator Ministro Carlos Britto, j. 30.4.2009. Informativo STF, $\mathrm{n}^{\circ}$ 
544, notícia: “ADPF e Lei de Imprensa - 8”. Disponível em: www.stf.jus.br. Último acesso em: 1.10.2009.

BRASIL. SUPREMO TRIBUNAL FEDERAL, Recurso Extraordinário 511.961/SP, Relator Ministro Gilmar Mendes, j. 17.6.2009. Informativo STF, $\mathrm{n}^{\circ}$ 551, notícia: "Art. 4", V, do Decreto-lei 972/69: Exigência de Curso de Jornalismo e Não-recepção - 6". Disponível em: www.stf.jus.br. Último acesso em: 1.10.2009.

BRASIL. TRIBUNAL DO RIO GRANDE DO NORTE, Apelação Cível nº 1422, Relator Desembargador SEABRA FAgundes, Revista de Direito Administrativo, vol. XIV, Rio de Janeiro, out-dez 1948, p. 52-82.

BREYER, Stephen; e STEWART, Richard. Administrative Law and Regulatory Policy. Boston and Toronto: Little, Brown and Company, 1979.

BRUNA, Sérgio Varella. Agências reguladoras: poder normativo, consulta pública e revisão judicial. São Paulo: Revista dos Tribunais, 2003.

BUCHANAN, James M. \& TULLOCK, Gordon. The calculus of consent: logical foundations of constitucional democracy. Michigan: The University of Michigan Press, 1962.

CAMPILONGO, Celso Fernandes. Direito e democracia. São Paulo: Max Limonad, 1997. . Política, sistema jurídico e decisão judicial. São Paulo: Max Limonad, 2001.

CAPPELLETTI, Mauro. "Who watches the Watchmen? A comparative study on judicial responsaibility". American Journal of Comparative Law. vol. 83 (1), p. 1-62.

CARDOSO, Fernando Henrique. O modelo político brasileiro e outros ensaios. $2^{\text {a }}$ ed., São Paulo: Difusão Européia do Livro, 1973. . Autoritarismo e democratização. $3^{\mathrm{a}}$ ed. Rio de Janeiro: Paz e Terra, 1975.

CARDOSO, Fernando Henrique; MARTINS, Carlos Estevam. Política \& Sociedade. São Paulo: Editora Nacional, 1979.

CARVALHO, José Murilo de. "Mandonismo, coronelismo, clientelismo: uma discussão conceitual". Dados. vol. 40 (2), Rio de Janeiro, 1997. Disponível em: http://www.scielo.br/scielo.php?pid=S0011-52581997000200003\&script=sci_arttext.

Último acesso em: 5.10.2009 . "Rui Barbosa e a razão clientelista". Dados. vol. 43 (1), Rio de Janeiro, 2000. Disponível em: $\quad$ http://www.casaruibarbosa.gov.br/dados/DOC /artigos/aj/FCRB_JoseMuriloCarvalho_Razao_clientalista.pdf.> Último acesso em: 4.10. 2009. 
CASSESE, Sabino. "Le autorità indipendenti: origini storiche e problemi odierni”.In: CASSESE, Sabino e FRANCHINI, Claudio. I garanti delle regole. Bologna: Il Mulino, 1996, p. 217-223.

. "Dalle regole del gioco al gioco com le regole". Mercato concorrenza regole. $\mathrm{n}$. 2, ago-2002, p. 265-276.

CHANDLER, Alfred. "Introdução a Strategy and structure". In: McCRAW, Thomas K. (Org.). Alfred Chandler: ensaios para uma teoria histórica da grande empresa. Trad. de Luiz Alberto Monjardim. Rio de Janeiro: FGV, 1998, p. 119-140.

CHANG, Ha-Joon. "The economics and politics of regulation". Cambridge Journal of Economics. vol. 21, 1997, p. 703-728.

CHEVALLIER, Jacques. "Régulation et polycentrisme dans l'administration française" $L a$ Revue Administrative. vol. 301, Paris, 1998, p. 43-53.

."La régulation juridique en question". Droit et Societé. vol. 49, 2001, p. 827-846.

COASE, Ronald. The firm, the market and the law. Chicago and London: The University of Chicago Press, 1990.

COMPARATO, Fábio Konder. O poder de controle na sociedade anônima. Atual. de Calixto Salomão Filho, $4^{\mathrm{a}}$ ed., Rio de Janeiro: Farense, 2005.

COMUNIDADE EUROPÉIA. Iniciativa européia em matéria de transparência (Livro Verde). Bruxelas: Comissão das Comunidades Européias, 3.5.2006, disponível em: 〈http://ec.europa.eu/transparency/eti/docs/gp_pt.pdf>, último acesso em 10.12.2008.

CORSI, Giancarlo, ESPÓSITO, Elena e BARALDI, Claudio. Glosario sobre la teoría social de Niklas Luhmann. Trad. de Miguel Romero Pérez e Carlos Villalobos, Guadalajara: Universidade Iberoamericana, 1996.

COUTINHO, Diogo Rosenthal. "Entre eficiência e eqüidade: a universalização das telecomunicações em países em desenvolvimento". Revista Direito $G V$, v. 1., n. 2., jun-dez 2005, p. 137-160.

COUTO E SILVA Almiro do. "Poder discricionário no Direito Administrativo Brasileiro". Revista de Direito Administrativo. vol. 179-180, jan-jun 1990, p. 51-92.

CRETELLA JR., José. Do ato administrativo. São Paulo: Bushatsky, 1977 O desvio de poder na Administração Pública. $4^{\mathrm{a}}$ ed., Rio de Janeiro: Forense, 1997.

CROLEY, Steven. "White House Review of Agency Rulemaking: an empirical investigation". The University of Chicago Law Review. vol. 70, 2003, p. 821-885. 
CRUZ, Verônica Paulino da. "Agências Reguladoras: entre mudanças institucionais e legados políticos". Tese de doutoramento em ciência política apresenta ao Instituto Universitário de Pesquisas do Rio de Janeiro. Rio de Janeiro, 2007.

CUÉLLAR, Leila. As agências reguladoras e seu poder normativo. São Paulo: Dialética, 2001.

Introdução às agências reguladoras brasileiras. Belo Horizonte: Fórum, 2008.

CUÉLLAR, Leila; e MOREIRA, Egon Bockmann. "As agências reguladoras brasileiras e a crise energética". Estudos de direito econômico. Belo Horizonte: Forum, 2004, 207-230.

CUSHMAN, Robert E. The independent regulatory commissions. New York: Octagon Books, 1972.

DE GIORGI, Raffaele. Direito, democracia e risco: vínculos com o futuro. Porto Alegre: Sérgio Fabris, 1998.

Direito, tempo e memória. Trad. de Guilherme Leite Gonçalves, São Paulo: Quartier Latin, 2006.

DEMSETZ, Harold. “Why regulate utilities?” In: STIGLER, George J. Chicago Studies in Political Economy. Chicago and London: The University of Chicago Press, 1988, p. 267278.

DEVILlENEUVE,L-M.; CARETTE, A.-A. e GILBERT, P. Recueil Général des Lois et des Arrêts en matiére civile, criminelle, administrative et de droit public. Paris: Bureaux de L'Administration du Recueil, 1865.

DI PIETRO, Maria Sylvia Zanella. Direito Administrativo, 20ª ed., São Paulo: Atlas, 2007. Direito Administrativo. 22 a ed., São Paulo: Atlas, 2009.

DIMAGGIO, Paul J. e POWELL, Walter W. "The iron cage revisited: institutional isomorphism and collective rationality in organizational fields". American Sociological Review. vol. 48 (2), 1983, p. 147-160.

DINIZ, Eli. Empresário, Estado e capitalismo no Brasil: 1930-1945. Rio de Janeiro: Paz e Terra, 1978.

"Empresário, democracia e desenvolvimento: tendências e desafios no limiar do novo milênio", 2004. Disponível em: <http://neic.iuperj.br/artigos.html >. Último acesso em: 15.06.2009.

DOWNS, Anthony. An economic theory of democracy. Boston: Addison-Wesley, 1957.

DUTRA, Pedro. “Órgãos reguladores: social-democracia ou neogetulismo?”. Livre concorrência e regulação dos mercados: estudos e pareceres. Rio de Janeiro: Renovar, 2003, p. 23-34. 
Agências reguladoras: reforma ou extinção?”. Revista de Direito Público da Economia. vol. 3, Belo Horizonte, jul.-set.2003, p. 187-208.

EDSALL, James K. “The Granger cases and the Police Power". Report of the Tenth Annual Meeting of the American Bar Association. vol. X, New York, 1887, p. 288-316.

EISENHARTDT, Kathleen M. "Agency theory: An assessment and review". Academy of Management. The Academy of MANAGEMENT Review; vol. 14 (1), jan-1989, p. 57-74.

EIZERIK, Nelson. O papel do Estado na regulação do mercado de capitais. Rio de Janeiro: IBMEC, 1977.

ESCOLA, Héctor Jorge. El interés público como fundamento del derecho administrativo. Buenos Aires: Depalma, 1989.

ESTADOS UNIDOS DA AMÉRICA. FEDERAL TRADE COMMISSION. "Enforcement perspectives on the Noerr-Pennington Doctrine: na FTC Staff Report”, 2006. Disponível em: http://www.ftc.gov/reports/P013518enfperspectNoerr-Penningtondoctrine.pdf. Último acesso em: 20.06.2009.

ESTADOS UNIDOS DA AMÉRICA. SUPREME COURT OF UNITED STATES. 295 US 602, Humphrey's Executor vs. United States (1935). Disponível em: <http://www.law.cornell.edu/supct/html/historics/USSC_CR_0295_0602_ZO.htmll>. Último acesso em: 1.10.2009.

ESTADOS UNIDOS DA AMÉRICA. TENNESSEE VALLEY AUTHORITY. TVA Act. Disponível em <http://www.tva.com/abouttva /pdf/TVA_Act.pdf $>$. Último acesso em: 27.10.2008.

EVANS, Peter. Embedded Autonomy: States \& Industrial Transformation. Princeton: Princeton University Press, 1995.

FAGUNDES, Márcia Margarete. "Teoria da captura do regulador de serviços públicos". In: SOUTO, Marcos Juruena Villela; e MARSHALL, Carla C.. Direito empresarial Público. Rio de Janeiro: Lumen Juris, 2002, p. 251-284.

FAGUNDES, Miguel Seabra. O controle dos atos administrativos pelo Poder Judiciário. Atual. por Gustavo Binenbojm, $7^{\mathrm{a}}$ ed., Rio de Janeiro: Forense, 2006.

FAORO, Raymundo. Os donos do poder: a formação do patronato político brasileiro. $3^{\mathrm{a}}$ ed. rev. São Paulo: Globo, 2001.

FARIA, José Eduardo. Direito e economia na democratização brasileira. São Paulo: Malheiros Editores, 1993.

. "As metamorfoses do direito na reestruturação do capitalismo" [2003], mimeo. . Direito e conjuntura. São Paulo: Saraiva, 2008. 
FARINA, Elizabeth Maria Mercier Querido; AZEVEDO, Paulo Furquim de; e SAES, Maria Sylvia Macchione. Competitividade: mercado, Estado e organizações. São Paulo: Editora Singular, 1997, p. 284

FERRARESE, Maria Rosaria. Diritto e mercato: il caso degli Stati Uniti. Torino: G. Giappichelli Editore, 1992.

FERRAZ, Anna Cândida da Cunha. Conflito de poderes - O poder congressual de sustar os atos normativos do Poder Executivo. São Paulo: RT, 1994.

FERRAZ JÚNIOR, Tércio Sampaio. "A relação meio/fim na teoria geral do Direito Administrativo". Revista de Direito Público. São Paulo, vol. 61, jan-mar 1982, p. 27-33.

. Teoria da Norma Jurídica, 4ª ed., Rio de Janeiro: Forense, 2006.

. "O poder normativo das agências reguladoras à luz do princípio da eficiência". In:ARAGÃO, Alexandre Santos de (Coord.). O poder normativo das agências reguladoras. Rio de Janeiro: Forense, 2006, p. 271-297.

"Interesse Público". Texto disponível em: <http://www.terciosampaioferrazjr.com.br/?q=/publicacoes-cientificas/34.> Último acesso: 21.11.2008.

FIANI, Ronaldo. “Afinal, a quais interesses serve a regulação?”. Economia e Sociedade. vol. 13, n. 2 (23), jul-dez 2004, p. 81-105.

FLIGSTEIN, Neil. The architecture of markets: an economic sociology of twenty-firstcentury capitalist societies. Princeton and Oxford: Princeton University Press, 2001.

FOLHA DE SÃO PAULO. "Pressionada, diretora da ANAC renuncia". Edição de 25.08.2007.

FOLHA ONLINE. "Anatel contraria Lula e autoriza reajuste de $28,75 \%$ na tarifa de telefone". Edição de 26.06.2003, 22:07h, Disponível em: <http://www1.folha.uol.com.br/folha/dinheiro/ult91u69415.shtml>

FRIEDMAN, Milton. "The Methodology of Positive Economics". Essays in positive economics. Chicago: University of Chicago Press, 1966, p. 3-16, 30-43.

GALBRAITH, John Kenneth. Anatomia do Poder. Trad. de HilárioTorloni, São Paulo: Pioneira, 1984.

GALA, Paulo. “A teoria institucional de Douglass North”. Revista de Economia Política, vol. 23, 2003, p. 89-105.

GAZETA MERCANTIL. "Hélio Costa defende intervenção na Anatel e adiamento de leilão". Edição de 23.08.2006, p. C1.

. “Zuanazzi cede a pressão e deixa Anac”. Edição de 31.10.2007, p. A8. 
GAZETA MERCANTIL (versão online). "Lula se opõe ao reajuste das tarifas". Gazeta Mercantil Edição de 26.06.2003, 17:00h. Disponível em: < $\underline{\text { http://indexet. }}$ gazetamercantil.com.br/arquivo/2003/06/26/70/TELECOM:-Lula-se-opoe-ao-reajuste-das$\underline{\text { tarifas.html }>}$

. "Reguladoras: Schymura oficializa renúncia da ANATEL”. Edição de 07.01.2004, 18:00h. Disponível em: <http://indexet.gazetamercantil.com.br/arquivo/ 2004/01/07/22/REGULADORAS:-Schymura-oficializa -renuncia -da-Anatel.html.

GHEVENTER, Alexandre. Autonomia versus controle: origens do novo marco regulatório antitruste na América Latina e seus efeitos sobre a democracia. Belo Horizonte: Editora UFMG, 2005.

GIDDENS, Anthony, BECK, Ulrich e LASH, Scott. Modernização Reflexiva: política, tradição e estética na ordem social moderna. Trad. de Magda Lopes, São Paulo: Editora Unesp, 1997.

GOULDNER, Alvin W. "Conflitos na teoria de Weber”. In: CAMPOS, Edmundo (org.). Sociologia da burocracia, Trad. de Edmundo Campos, $4^{\mathrm{a}}$ ed., Rio de Janeiro: Zahar Editores, 1978, p. 59-67

GRANOVETTER, Mark. "Economic action and social structure. The problem of Embeddedness". The American Journal of Sociology. vol. 91 (3), 1985, p. 481-510.

GRAU, Eros Roberto. A ordem econômica na Constituição de 1988. $8^{\mathrm{a}}$ ed. rev. e atual. São Paulo: Malheiros, 2003.

."Notas sobre o anteprojeto de lei atinente às agências". Revista de Direito Público da Economia. v. 4, Belo Horizonte, out./dez. 2003, p. 111-118.

GRAZIANO, Luigi. "Lobby e o interesse público". Trad. de Vera Pereira. Revista Brasileira de Ciências Sociais. vol. 12, n. 35, São Paulo, fev-1997, p. 5. A versão consultada está disponível em: < script=sci_arttext\&pid=S0102-69091997000300009>. Último acesso em: 15.06.2009.

HANDLER, Milton e DE SEVO, Richard A.. "The Noerr doctrine and its sham exception". Cardozo Law Review. vol. 6 (2), 1984-1985, p. 1-69.

HOLANDA, Sérgio Buarque. Raízes do Brasil (edição comemorativa 70 anos). São Paulo: Companhia das Letras, 2006.

HORWITZ, Robert. The irony of regulatory reform: the deregulation of American telecommunications, New York and Oxford: Oxford University Press, 1989.

HUNTINGTON, S. P. "The marasmus of the ICC: The Commission, the Railroads by independent commission”. Yale Law Journal, vol. 61, apr. 1962, p. 467-509. 
JAFFE, Louis L. "The independent agency - a new scapegoat" (Review of Regulating Business by Independent Comission. By Marver H. Bernstein). The Yale Law Journal. vol. 65, 1955-1956, p. 1068-1076.

JENSEN, Michael C. e MECKLIN, William. "Theory of the firm: Managerial behavior, agency costs, and ownership structure”. Journal of Financial Economics, vol. 3 (4), Octobre- 1976, p. 305-360. Disponível em: http://ssrn.com/abstract=94043. Último acesso em: 01.10.2008.

JÈZE, Gaston. Principios generales del derecho administrativo. vol. III, Buenos Aires: Editorial Depalma, 1949.

JORDAN, Grant [et. al.]. "Les groupes d' intérêt public". Pouvoirs: Revue Française d'Études Constitutionnnelles et Politiques. vol.79, Paris, 1996, p. 69-85.

JORDANA, Jacint; e SANCHO, David. "Regulatory designs, institucional constellations and the study of the regulatory state". In: JORDANA, Jacint. e LEVI-FAUR, David. The politics of regulation: institutions and regulatory reforms for the age of governance. Cheltenham: Edward Elgar, 2004, p. 296-319

JORDÃO, Eduardo Ferreira. Repensando a teoria do abuso de direito. Salvador: JusPODIVM, 2006.

- "O direito antitruste e o controle do lobby por regulação restritiva da concorrência”. Revista de Direito Público da Economia. vol. 25, jan-mar 2009, p. 63-100.

JUSTEN FILHO, Marçal. O direito das agências reguladoras independentes. São Paulo: Dialética, 2002.

JUVENAL, Satura VI. Disponível em: 〈http://www.thelatinlibrary.com/juvenal/6. shtml $>$. Último acesso em: 10.05.2009.

KALT, Joseph e ZUPAN, Mark. "Capture and ideology in the economic theory of politics". American Economic Review. vol. 74 (3), 1984, p. 279-300.

KELSEN, Hans. Teoria Pura do Direito. Trad. de João Baptista Machado, $7^{\text {a }}$ ed., São Paulo: Martins Fontes, 2006.

Teoria Geral das Normas. Trad. de José Florentino Duarte. Porto Alegre: Sérgio Antônio Fabris Editor, 1986.

KEYNES, J. Neville. The Scope and Method of Political Economy. Kitchener: Batoche Books, 1999

KRUGMANN, Paul. Vendendo Prosperidade: sensatez e insensatez econômica na era do conformismo. Trad. de Maria Luiza Neuwlands Silveira. Rio de Janeiro: Campus, 1997. 
LARENZ, Karl. Derecho Justo: fundamentos de ética jurídica. Trad. de Luis Díez-Picazo. Madrid: Civitas, 1985.

LEAL, Victor Nunes. Coronelismo, enxada e voto. Rio de Janeiro: Forense, 1948. . "Poder discricionário e ação arbitrária da Administração." Revista de Direito Administrativo. vol. XIV, Rio de Janeiro, out.-dez 1948, p. 53-82.

LESSIG, Lawrence e SUNSTEIN, Cass R. "The President and the Administration". Columbia Law Review. vol. 94 (1), jan-1994, p. 1-123.

LEVINE, Michael E. "Revisionism revised? Airline Deregulation and the Public Interest". Law and Contemporary Problems, vol. 44, abr. 1981, p. 179-185.

. "Regulatory Capture", In: NEWMAN, Peter (Ed.).The New Palgrave Dictionary of Economics and the law. vol.3, New York: Palgrave Macmillan, 2002, p. 267-271.

. "Regulation, the market and interest group cohesion: why airlines were not reregulated". New York University Law and Economics Working Papers. Paper 80, 2006. Disponível em: http://lsr.nellco.org/nyu/lewp/papers/80, acessado em 31.03.2008.

LEVINE, Michael e FORRENCE, Jennifer L. "Regulatory capture, public interest, and the public agenda: toward a synthesis". Journal of Law, Economics, and Organization. vol. 6 (Special Issue), 1990, p. 167-198.

LUHMANN, Niklas. Legitimação pelo procedimento. Trad. de Maria da Conceição CôrteReal, Brasília: Editora Universidade de Brasília, 1980.

. Sociologia do Direito. Trad. de Gustavo Bayer, vol.I, Rio de Janeiro: Tempo Brasileiro, 1983.

. Sociologia do Direito. Tradução de Gustavo Bayer, vol. II, Rio de Janeiro: Edições Tempo Brasileiro, 1985.

Sociologia del rischio. Trad. de: Giancarlo Corsi, Torino e Milano: Bruno Mondadori, 1996.

. Teoría política en el Estado de Bienestar. Trad. de Fernando Vallespín, Madrid: Alianza Editorial, 1997.

El derecho de la sociedad. Trad. de Javier Torres Nafarrate, México: Universidad Iberoamericana, 2002.

LUNA, Everardo da Cunha. Abuso de Direito. Rio de Janeiro: Forense, 1959.

MACEDO JÚNIOR, Ronaldo Porto. "Relacionamento e competência das agências". In: MARQUES NETO, Floriano de Azevedo (Coord.). "Há um déficit democrático nas agências reguladoras?" (Palestras e Debates). Revista de Direito Público da Economia. vol. 5, jan-mar 2004, p. 181-182. 
MAJONE, Giandomenico. "The rise of the regulatory State in Europe". In: BALDWIN, Robert.; SCOTT, Colin; e HOOD, Christopher (Ed.). A reader on regulation. New York: Oxford University Press, 1998, p. 192-215.

. "Do Estado Positivo ao Estado Regulador: causas e conseqüências da mudança no modo de governança". Trad. de: Paulo Todescan L. Mattos. In: MATTOS, Paulo Todescan L. (org.). Regulação Econômica e democracia: o debate europeu. São Paulo: Singular, 2006, p. 53-85.

MAKKAI, T. e BRAITHWAITE, J. "In and out of the Revolving Door: making sense of regulatory capture”. In: BALDWIN, Robert; SCOTT, Colin; e HOOD, Christopher (Ed.). A reader on regulation. New York: Oxford University Press, 1998, p. 173-191.

MANERO, Juan Ruiz. Ilícitos atípicos: sobre el abuso del derecho, el fraude de ley y la desviación de poder. Madrid: Editorial Trotta, 2000.

MANTZAVINOS, C. Individuals, institutions and markets. Cambridge: Cambridge University Press, 2001.

MARQUES NETO, Floriano de Azevedo. Regulação Estatal e interesses públicos. São Paulo: Malheiros, 2002.

Agências reguladoras: instrumentos do fortalecimento do Estado. São Paulo: ABAR, [s/d].

MARQUES, Maria Manuel Leitão [et. al.]. "Regulação Sectorial e concorrência”. Revista de Direito Público da Economia - RDPE. n. 9, Belo Horizonte, jan - mar 2005, p. 187205.

MARTINS, Carlos Estevam. Capitalismo de Estado e modelo político no Brasil. Rio de Janeiro: Graal, 1977.

MARTINS-COSTA Judith. A boa-fé no Direito Privado: sistema e tópica no processo obrigacional. São Paulo: Revista dos Tribunais, 2000.

MASHAW, Jerry L. "The economics of politics and the understanding of public law". Chicago-Kent Law Review. vol. 65, 1989, p. 122-160.

Greed, Chaos and Gonvernance: using public choice to improve Public Law. New Haven and London: Yale University Press, 1997.

. "Reinventando o governo e reforma regulatória: estudos sobre a desconsideração e o abuso do Direito Administrativo". Trad. de Caio Mário da Silva Pereira Neto. In: MATTOS, Paulo Todescan L. (Org.). Regulação econômica e democracia: o debate norteamericano. São Paulo Editora 34, 2004, p. 281-300. 
MATTOS, Paulo Todescan Lessa. "O novo Estado Regulador no Brasil: Direito e Democracia”. Tese de Doutorado apresentada à Faculdade de Direito da Universidade de São Paulo. 2004.

"Agências reguladoras e democracia: participação pública e desenvolvimento". In: SALOMÃO Filho, Calixto (Coord). Regulação e desenvolvimento. São Paulo: Malheiros, 2002, p. 182-230.

McCRAW, Thomas K. Prophets of regulation. Cambridge and London: Harvard University Press, 1984.

McCUBBINS, Mathew e LUPIA, Arthur. "Learning from oversight: fire alarms and police patrols reconstructed". Journal of Law, Economics \& Organization. vol. 10, 1994, p. 96125.

McCUBBINS, Mathew, NOLL, Roger G. e WEINGAST, Barry R. "Administrative Procedures as instruments of political control". In: JOSKOW, Paul L. Economic Regulation. Cheltenham and Northampton: Elgar, 2000, p. 88-122.

McCUBBINS, Mathew e SCHWARTZ. Thomas "Congressional oversight overlooked: police patrols versus fire alarms". American Journal of Political Science. vol. 28 (1), feb. 1984, p. $165-179$

MEDAUAR, Odete. O Direito Administrativo em evolução. $2^{\mathrm{a}}$ ed. rev., ampl. e atual. São Paulo: Revista dos Tribunais, 2003.

MELLO, Rafael Munhoz de. Princípios constitucionais de Direito Administrativo Sancionador: as sanções administrativas à luz da Constituição Federal de 1988. São Paulo: Malheiros, 2007.

MENDES, Conrad Hübner. "Reforma do Estado e agências reguladoras: estabelecendo os parâmetros de discussão". Direito Administrativo Econômico. São Paulo: Malheiros, 2002, p. 99-139.

MENDES,Gilmar Ferreira; COELHO, Inocêncio Mártires e BRANCO, Paulo Gustavo Gonet. Curso de Direito Constitucional. 2a ed., São Paulo: Saraiva, 2008.

MENEZES CORDEIRO, A. Manuel. Da boa fé no direito civil. Coimbra: Almedina, 1987. MERUSI, Fábio e PASSARO, Michele. Le autorità indipendenti: un potere senza partito. Bologna: il Mulino, 2003.

MINDA, Gary. "Interest groups, political freedom, and antistrust: a modern reassessment of the Noerr-Pennington Doctrine”. Hastings Law Journal. vol. 41, 1989-1990, p. 9051028. 
MOE, Thomas. "Regulatory Performance and Presidential Administration". American Journal of Political Science. vol. 26 (2), may-1982, p. 197-224.

MONTERO AROCA, Juan. Sobre la imparcialidade del juez y la incompatibilidad de funciones procesales. Valencia: Tirant lo blanch, 1999.

MOREIRA, Egon Bockmann. Processo Administrativo. $3^{\text {a }}$ ed., São Paulo: Malheiros, 2007.

. “Agências reguladoras independentes, déficit democrático e a "elaboração processual de normas". Revista de Direito Público da Economia. vol. 2, Belo Horizonte, abr-jun 2003, p. 221-255.

. “Anotações sobre a história do Direito Econômico Brasileiro". Revista de Direito Público da Economia. vol. 6, Belo Horizonte, abr.-jun. 2004, p. 76-96.

. "Os limites à competência normativa das agências reguladoras”. In: ARAGÃO,

Alexandre Santos de (Coord.). O poder normativo das agências reguladoras. Rio de Janeiro: Forense, 2006, p. 173-220.

MOREIRA, Vital. Auto-regulação profissional e Administração Pública. Coimbra: Almedina, 1997.

MOREIRA, Vital e MAÇÃS, Fernanda. Autoridades reguladoras independentes: estudo e projeto de lei-quadro. Coimbra: Coimbra Editora, 2003.

NEE, Victor. "New institutucionalism, economic and sociological". Center for the Study of Economic and Society”. Disponível em: <http://economyandsociety.org/publications/wp4_nee_03.pdf>. Último acesso em: 20.10.2007.

NISKANEN JR., William A. Bureaucracy \& Representative Government. New Brunswick and London: Aldine Transaction, 1971.

NORTH, Douglass C. Institutions, institutional change and economic performance. Cambridge: Cambridge University Press, 1990.

NUNES, Edson. A gramática política no Brasil: clientelismo e insulamento burocrático. Rio de Janeiro: Jorge Zahar Editor, 1997.

. "O quarto poder: gênese, contexto, perspectivas e controle das agências

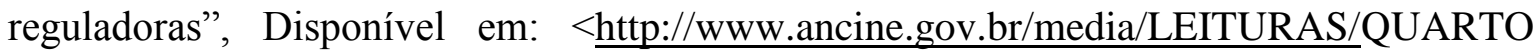
_PODER.pdf.> Último acesso em: 01.07.2008.

NUNES, Edson [et. al.]. Agências reguladoras e reforma do Estado no Brasil: inovação e continuidade no sistema político-institucional. São Paulo: Garamond, 2007. 
NUSDEO, Ana Maria de Oliveira. "A regulação e o direito da concorrência”. In: SUNDFELD, Carlos Ari. Direito Administrativo Econômico. São Paulo: Malheiros, 2002, p. $159-189$.

NUSDEO, Fábio. Fundamentos para uma codificação do direito econômico. São Paulo: Revista dos Tribunais, 1995.

. “O Direito Econômico e os grupos de pressão". In: GRINOVER, Ada Pellegrini (Coord.). A tutela dos interesses difusos. São Paulo: Max Limonad, 1984, p. 153-176.

OCDE. "Brazil: strengthening for growth". OECD Review of Regulatory Reform. Paris: OECD, 2008.

O’DONNEL, Guillermo. Reflexões sobre os Estados burocráticos-autoritários. Tradução de: Cláudia Schilling, São Paulo: Vértice, 1987.

O ESTADO DE SÃO PAULO. "Loteamento das agências”. Edição de 18.06.2008. . "Preservar a ANEEL". Edição de 04.12.2006

O ESTADO DE SÃO PAULO (versão online). "Jobim reitera renovação completa da ANAC após saída de Barat". Edição de 26.09.2007, 12:51h. Disponível em: <http://www.estadao.com.br/cidades/not_cid57049,0.htm>

. “Zuanazzi está sozinho na ANAC após renúncia do quarto diretor”. Edição de 26.09.2007, 08:23h. Disponível em: <http://www.estadao.com.br/cidades/not $\underline{\text { cid56989,0.htm }>}$

OLIVEIRA, Andréa C. J.. "Lobby e Representação de Interesses: lobistas e seu impacto sobre a representação de interesses no Brasil". Tese de Doutorado apresentada ao Instituo de Filosofia e Ciências Humanas da Universidade Estadual de Campinas, 2004.

OLIVEIRA, Gesner; FUJIWARA, Thomas e MACHADO, Eduardo Luiz. "A experiência brasileira com agências reguladoras". Trabalho desenvolvido por iniciativa do Conselho de Infra-estrutura da Confederação Nacional da Indústria - CNI. Disponível em: www.goassociados.com.br/papers/Agencias_IPEA_Final.pdf. Último acesso em: 20.12.2008.

OLSON, Marcur. The logic of collective action: public goods and the theory of groups. Cambridge: Harvard University Press, 1965.

PACHECO, Regina Silvia. "Regulação no Brasil: desenho das agências e formas de controle". Revista Eletrônica sobre a Reforma do Estado. Salvador, n ${ }^{\circ}$ 7, set-nov 2006, p 15. Disponível em: <www.direitodoestado.com.br>. Último acesso em: 20.06.2009 PARGAL, Sheoli. "Regulation and private sector investment in infrastructure: evidence from Latin America. Policy Research Working Paper n 3037. The Work Bank, abr. 2003. 
Disponível em: http://papers.ssrn.com/sol3/papers.cfm?abstract_id=636399. Último acesso em: 01.07.2008.

PECI, Alketa. Novo marco regulatório para o Brasil pós-privatização: o papel das agências reguladoras em questão. Trabalho apresentado no Encontro Anual da Associação Nacional de Pós-Graduação e Pesquisa em Administração - ENANPAD. 1999, Disponível em: <http://www.anpad.org.br/enanpad/1999/dwn /enanpad1999-ap-13.pdf.> Último acesso em 08.05.2009.

PECI, Alketa e CAVALCANTI, Bianor Scelza. "A outra face da regulação: o cidadãousuário de serviços públicos no novo modelo regulatório brasileiro". Revista de Direito Público da Economia. v. 3, Belo Horizonte, jul.-set. 2003, p. 9-31.

PELTZMAN, Sam. "Toward a more general theory of regulation”. In: STIGLER, George J. (Ed.). Chicago Studies in Political Economy. Chicago: University of Chicago Press, 1988, p. 234-266.

. "Theory of regulation after a decade of deregulation". Political participation and government regulation. Chicago: University of Chicago Press, 1998, p. 155-187.

PINTO, Bilac. Regulamentação efetiva dos serviços de utilidade pública. Atual. de Alexandre Santos de Aragão. $2^{\text {a }}$ ed., São Paulo: Forense, 2002.

PIZZORUSSO, Alessandro. "Interesse pubblico e interessi pubblici". Revista Trimestrale di Diritto e Procedura Civile. Milano, ano XXVI, mar. 1972, p. 57-87.

POSNER, Richard. "Teorias da regulação econômica". In: MATTOS, PAULO TODESCAN L. (ORG.), Paulo (Coord.). Regulação econômica e democracia: o debate norte-americano. Trad. de Mariana Mota Prado, São Paulo, Editora 34, 2004, p. 49-80.

PRADO, Mariana da Mota. "Independent Regulatory Agencies, Patronage, and Clientelism: lessons from Brazil”. Laboratório de Documentación e Análisis de la corrupción y la transparencia. Ciudad de México: Instituto de Investigaciones Sociais IIS, 2006. Disponível em: <http://www.derechoasaber.org.mx/documentos/pdf0103.pdf ?PHPSESSID=f341dd5e3c563f62bb69f68fcf90a350>. Último acesso em: 20.12.2008.

- "The challenges and risks of creating independent regulatory agencies: a cautionary tale from Brazil”. University of Toronto Legal Studies Series: Research Paper $n^{\circ}$ 983.907, apr-2007. Disponível em: http://ssrn.com/abstract=983807. Último acesso em: 20.12.2008.

PRIEST, George L. "The origins of utility regulation and the "theories of regulation" debate". The Journal of Law \& Economics. vol. XXXVI,Chicago, apr-1993, p. 289-323. 
PRZEWORSKI, Adam. "Sobre o desenho do Estado: uma perspectiva agent x principal" In: BRESSER-PEREIRA, Luiz e SPINK, Peter (org.). Reforma do Estado e Administração Pública Gerencial. $4^{\text {a }}$ ed. Rio de Janeiro: FGV, 2001, p. 39-71.

PROSSER, Tony. "Theorizing utility regulation". The modern law review. vol. 62, 1999, p. 196-217.

QUEIRÓ, Afonso Rodrigues. "A teoria do 'desvio de poder' em Direito Administrativo". Revista de Direito Administrativo. vol. VII, jan-mar 1947, p. 52-80.

QUIRK, Paul J. Industry Influence in Federal Regulatory Agencies. Princeton: Princeton University Press, 1981.

RIBEIRO, Maria Teresa de Melo. O princípio da imparcialidade da Administração Pública. Coimbra: Almedina, 1996.

RINGER, Fritz. A metodologia de Max Weber: unificação das ciências culturais e sociais. Trad. de Gislon César Cardoso de Sousa. São Paulo: Edusp, 2004.

RIVERO, Jean. Direito Administrativo. Trad. de Rogério Ehrhardt Soares, Coimbra: Almedina, 1981.

ROCHE, Marie-Anne Frison. "Definição do direito da regulação econômica". Revista de Direito Público da Economia - RDPE. n. 9, Belo Horizonte, jan-mar 2005, p. 207-217.

. “Os novos campos da regulação". Revista de Direito Pública da Economia RDPE. n. 10, Belo Horizonte, abr-jun 2005, p. 191-221.

ROSENN, Keith S. "The Jeito: Brazil's Institutional Bypass of the Formal Legal System and its Developmental Implications". The American Journal of Comparative Law. vol. 19, 1971, p. 514-549.

. "Trends in Brazilian Regulation of Business". Lawyer of the Americas. vol. 13, 1981, p. 169-209.

. "Brazil's Legal Culture: The Jeito revisited". Florida International Law Jounal. vol. 1 (1), 1984, p. 1-43.

ROTHSTEIN, Henry; HUBER, Michael; e GASKELL, George. "A theory of risk colonization: the spiraling regulatory logics of societal and institutional risk". London: LSE Research Online. Disponível em: http://eprints.lse.ac. Uk/2675.Último acesso em: 1.10.2009.

SALGADO, Lúcia Helena. "Agências regulatórias na experiência brasileira: um panorama do atual desenho institucional". Texto para Discussão. n 941, Rio de Janeiro: IPEA. Disponível em: <www.ipea.gov.br>, último acesso em 06.05.2005. 
SALOMÃO FILHO, Calixto. Regulação da atividade econômica (princípios $e$ fundamentos jurídicos). São Paulo: Malheiros, 2001.

SCHMITTER, Philippe C.. "Still the century of corporativism?" Review of Politics. vol. 36 (1), 1974, p. 85-131.

SCHWARTZ, Bernard. American Constitutional Law, Cambridge: The University Press, 1955.

SELZNICK, Philip. "Cooptação: um mecanismo para a estabilidade organizacional”. In: CAMPOS, Edmundo. Sociologia da burocracia. Trad. de Edmundo Campos, $4^{\mathrm{a}}$ ed., Rio de Janeiro: Zahar Editores, 1978, p. 93-100.

SEN, Amartya. "Rationality and social choice". The American Economic Review, vol. 85 (1), 1995, p. 1-24.

SEN, Amartya. Sobre Ética e Economia. Trad. de Laura Teixeira Motta, São Paulo: Companhia das Letras, 1999.

SHAPIRO, Martin. The Suprem Court and Administrative Agencies. New York: Free Press, 1968.

Who guards the Guardians? Judicial Control of Administration. Athens and London: The University of Georgia Press, 1988.

SIMON, Herbert. A. "A behavioral model of rational choice". The Quartely Journal of Economics. vol. 69 (1), 1955, p. 99-118.

SOARES, Rogério Ehrardt. "Princípio da legalidade e Administração constitutiva". Boletim da Faculdade de Direito da Universidade de Coimbra. vol. LVII, Coimbra, 1981, p. $169-181$

STIGLER, George J. e FRIEDLAND, Claire."What Can regulators regulate? The case of Eletricity", The citizen and the State: essays on regulation. Chicago and London: The University of Chicago Press, p. 61-77.

. The theory of economic regulation". The citizen and the State: essays on regulation. Chicago and London: The University of Chicago Press, p. 114-141.

. "Economics or Ethics?” The Tanner Lectures on Human Values. Disponível em: www.tannerlectures.utah.edu/lectures/stigler81.pdf, último acesso em 20.10.2007. STIGLITZ, Joseph E.. "Information and the change in the paradigm in Economics". Disponível em: <http://nobelprize.org/nobel_prizes/economics/laureates/ 2001/stiglitzlecture.pdf > . Último acesso em: 1.10.2009. 
STONE, Julius. The province and function of law: law as logic, justice and social control. $2^{\text {nd }}$ ed., Cambridge: Harvard University Press, 1950.

STRAUSS, Peter L e SUNSTEIN, Cass R. "The role of the President and OMB in informal rulemaking”. Administrative Law Review. vol. 38, 1986, p. 181-207.

SUNDFELD, Carlos Ari. “A regulação das telecomunicações: papel atual e tendências futuras". Revista Diálogo Jurídico. Salvador, vol. I, $\mathrm{n}^{\circ}$ 3, jul-2001. Disponível em: <http://www.direitopublico.com.br/pdf_3/DIALOGO-JURIDICO-03-JUNHO-CARLO SARI-SUNDFELD.pdf>. Último acesso em 08.05.2009.

SUNSTEIN, Cass R. "Paradoxes of Regulatory State". The University of Chicago Law Review. vol. 57, 1990, p. 407-441.

. "O constitucionalismo após o New Deal". Trad. de Jean Paul Cabral Veiga da Rocha. In: MATTOS, Paulo Todescan L. (Org.). Regulação econômica e democracia: o debate norte-americano. São Paulo: Editora 34, 2004, p. 131-242.

SWEDBERG, Richard. Principles of economic sociology. Princeton and Oxford: Princeton University Press, 2003.

. "New Economic Sociology: What has been accomplished, What is ahead?" Acta Sociologica. vol. 40(2), 1997, p. 161-182.

TÁCITO, Caio. "O desvio de poder no controle dos atos administrativos, legislativos e jurisdicionais". Revista de Direito Administrativo. vol. 228, abr-jun 2002, p. 1-12.

TRAIN, Kenneth E. Optimal Regulation: the economic theory of natural monopoly, Cambridge and London: MIT Press, 1991.

TELBERRY, James H. "Lobbying - a definition an recapitulation of its practice". Ohio State Law Journal. vol. 11, 1950, p. 557-569.

TELEBRASIL - Associação Brasileira de Telecomunicações. "Plano de Ação". Disponível em <http://www.telebrasil.org.br/associacao/index.asp?m=plano-acao.htm $>$. Ultimo acesso em 28.11.2008. . “(Tele) Comunicações 2015: contribuições para o aperfeiçoamento do modelo”.

Disponível em: <http://www.telebrasil.org.br/tel-inc-soc/index.asp?m=inicio.htm/>. Último acesso em 28.11.2008

. "Livro Azul". Disponível em: < $\underline{\text { http://www.telebrasil.org.br/publicacoes/ }}$ index.asp?m=livroazul.htm $>$. Último acesso em 28.11.2008.

TEPEDINO,Gustavo; BARBOZA, Heloísa Helena e MORAES, Maria Celina Bodin de. Código Civil interpretado conforme a Constituição da República. vol. I, $2^{\mathrm{a}}$ ed. rev. e atual., Rio de Janeiro: Renovar, 2007. 
TEREPINS, Sandra. "Sham litigation - uma exceção à doutrina Noerr-Pennington e a experiência recente vivida pelo CADE”. Revista do IBRAC. vol. 15 (1), 2008, p. 63-97.

TEUBNER, Gunther. O direito como sistema autopoiético. Trad. de José Engrácia Antunes. Lisboa: Fundação Calouste Gulbenkian, 1989.

TEUBNER, Gunther. "Dopo la privatizzazione: il ritorno dei confliti politici nei private governments". Diritto policontestuale: prospettive giuridiche della pluralizzazione dei mondi sociali. Tradução de Beatrice Bodmer e Enrica Mazza-Teubner. Napoli: Edizioni Città del Sole, 1999, p. 143-175.

- "After legal instrumentalism? Strategic models of post-regulatory law". In: SCOTT, Colin (Ed.). Regulation. The International Library of Essays in Law \& Legal Theory. Aldershot: Ashgate, 2003, p. 49-74.

Direito regulatório: crônica de uma morte anunciada". Trad. de: Rodrigo Octávio Broglia Mendes. In: TEUBNER, Gunther. Direito, sistema e policontextualidade. Piracicaba: Editora Unimep, 2005, p. 21-54.

. "The corporate codes of multinationals: company constitutions beyond corporate governance and co-determination". In: NICKEL, Rainer (ed.). Conflict of Laws and Laws of Conflict in Europe and Beyond: Patterns of Supranational and Transnational Juridification, Oxford: Hart, 2009. Disponível em: <http://www.jura.unifrankfurt.de/ifawz1/teubner/dokumente/CorporateCodes_eng.pdf. $>$ Último acesso em: 8.5.2009.

TOSINI, Domenico. "The welfare courts: a socio-legal analysis of risk management modern strict liability". International Journal of the Socioloby of Law. vol. 33, 2005, p. 200-214.

VALOR ECONÔMICO. "Aneel aprova medida que afeta preço de energia”. Edição de 29.11.2006.

. "Loteamento político mina as agências reguladoras". Edição de 19.01.2005 . "Programa para agências reforça temor de ingerência". 20.03.2007.

VISCUSI, W. K. [et. al.]. Economics of regulation and antitrust. $4^{\text {th }}$ ed. Cambridge: MIT Press, 2005.

VOLPI, Alexandre. A história do consumo no Brasil. Rio de Janeiro: Elsevier, 2007.

WEBER, Max. "A “objetividade” do conhecimento nas ciências sociais". Trad. de Gabriel Cohn. In: COHN, Gabriel (org.) e FERNANDES, Florestan (coord.). Max Weber. $7^{\mathrm{a}}$ ed., São Paulo: Ática, 2006, p. 79-127. 
WEBER, Max. Economia e Sociedade. vol. I, Trad. de Regis Barbosa e Karen Elsabe Barbosa, São Paulo: Editora UNB/Imprensa Oficial do Estado de São Paulo, 2004.

WEINGAST, Barry R. e MORAN, Mark J. "Bureaucratic Discretion or Congressional Control? Regulatory policymaking by the Federal Trade Comission”. Journal of Political Economy. Vol. 91 (1), feb-1983, p. 765-800.

WILLIAMSON, Oliver. The mechanisms of governance. New York: Oxford University Press, 1996.

WILLKE, Helmut. "The Tragedy of the State. Prolegomena to a Theory of the State in Polycentric Society”. Archiv für Rechts-und Sozialphilosophie, Bd.72, Nr.4, 1986, S. 455467. Disponível em: <http://www.uni-bielefeld.de/soz/globalgov//Lit/Willke Tragedy_State.pdf. $>$ Último acesso em: 8.5.2009.

WILSON, James Q. The politics of regulation. New York: Basic Books, 1980.

WOOLCOCK, Michael. "Social capital and economic development: toward a theoretical synthesis and policy framework”. Theory and Society. vol. 27 (2), apr-1998, p. 151-208. 